Historic, Archive Document

Do not assume content reflects current scientific knowledge, policies, or practices. 



\section{4}
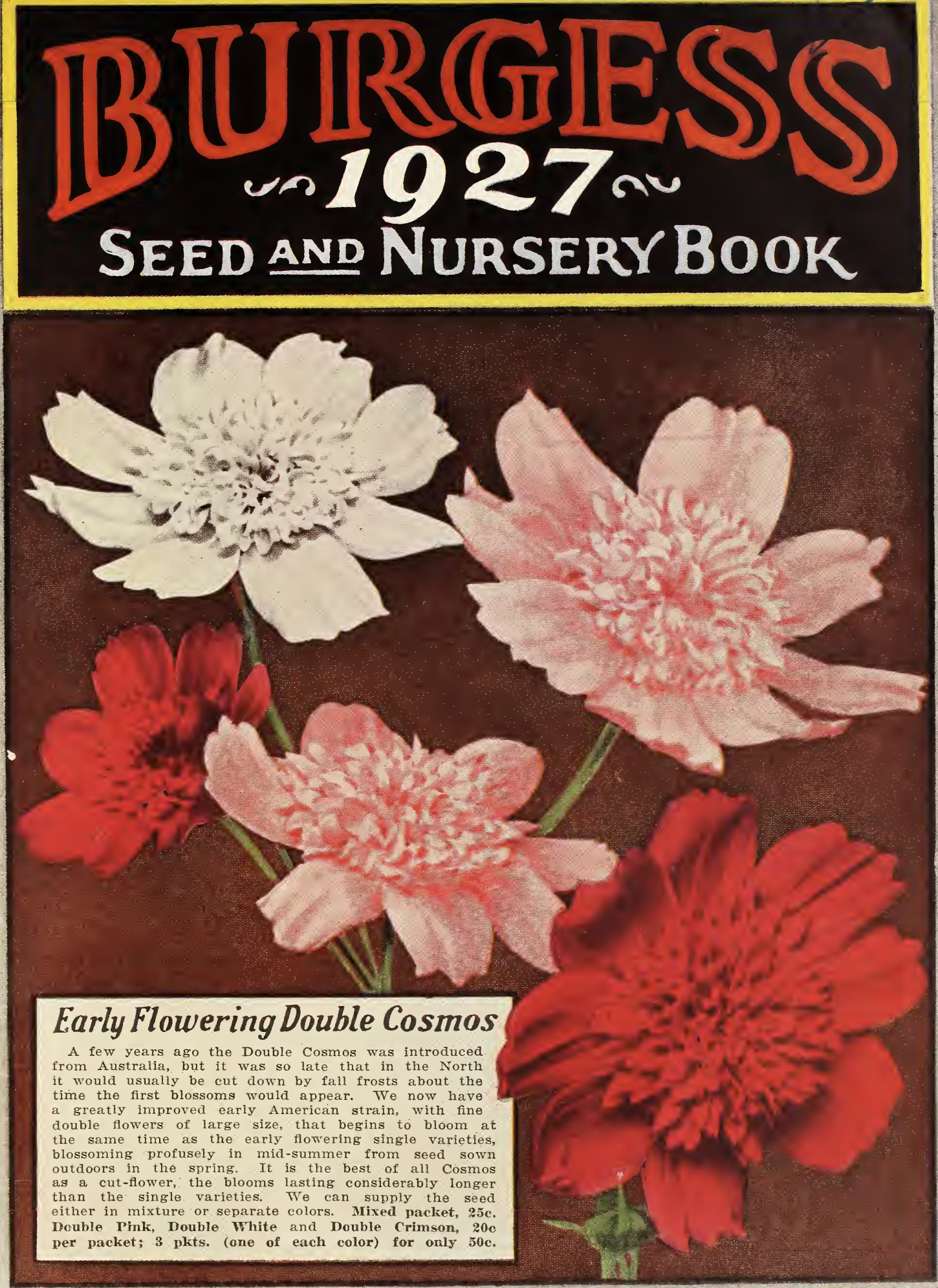

Burgess Seed E-Plant Co.Galesburg Mich. 

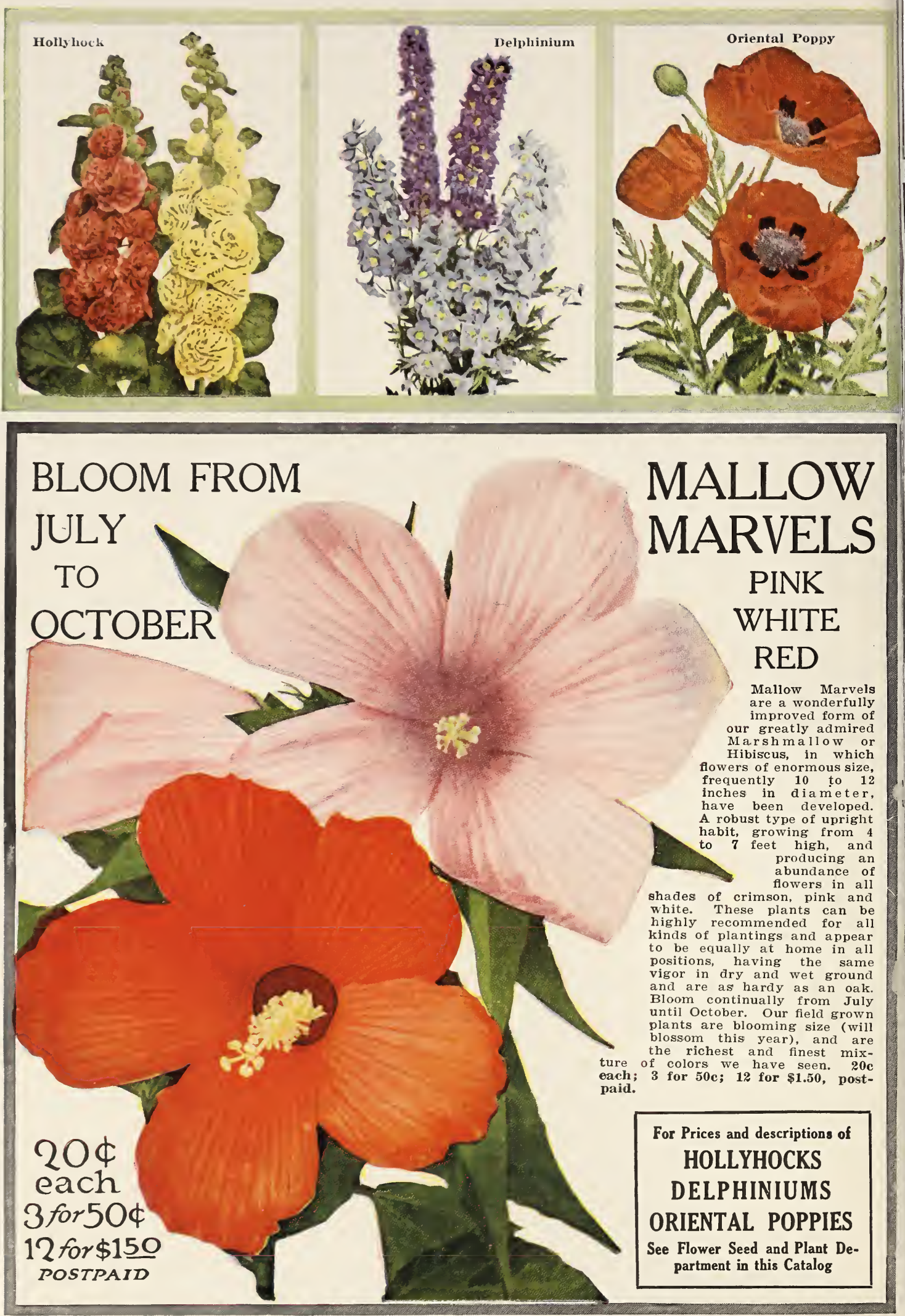


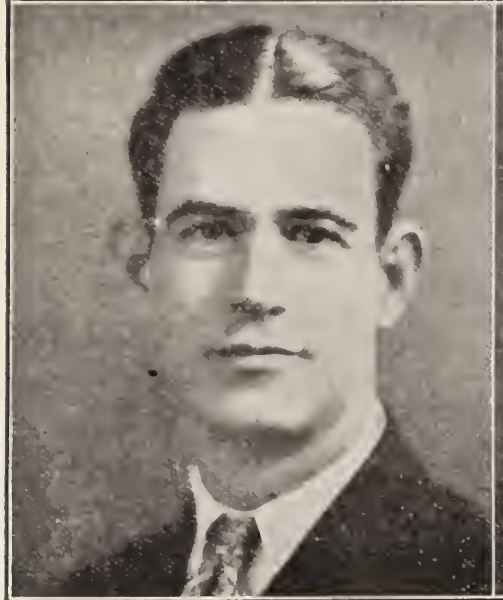

E. 11. ISURGESS

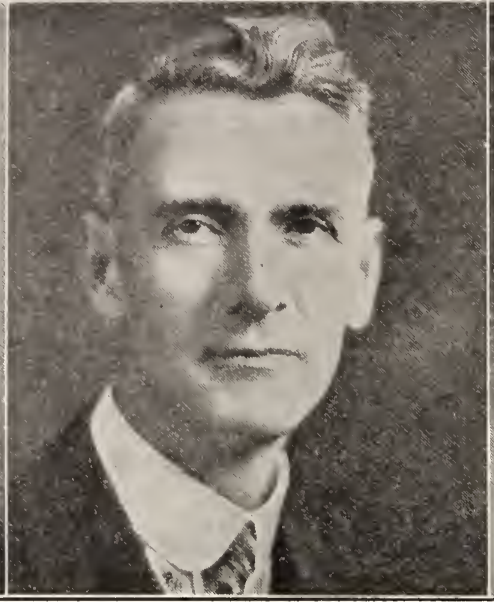

H. W. BURGESS

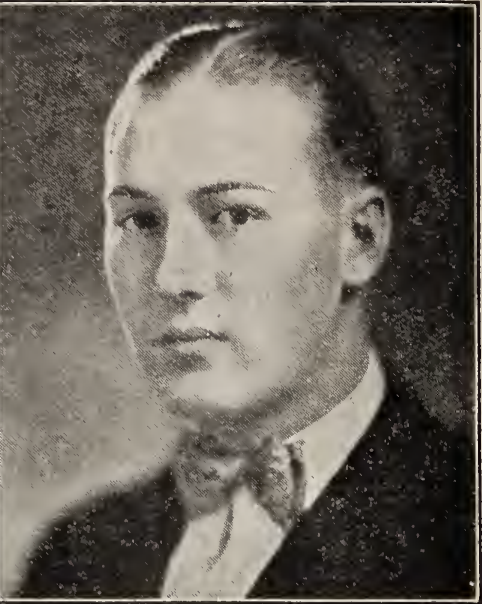

D. E. BURGESS

\section{The Burgess Guarantee of Satisfaction}

\section{Seed Guarantee}

We positively guarantee all seeds sold by us to be exactly as described in this catalog, and fresh, pure, gemuine and unadulterated, carefully selected and tested.

We also guarantee them true-to-name, and will replace, free of charge, any that may prove otherwise throngh a possible error.

We also guarantef our seeds to be of high germination. for we exercise great care in growing, selecting and sorting all seeds before sending them out, and we guarantee all seeds we send out to arrive in good order.

We do not guarantee crop. No reasonable person could expect us to do that. Even with Burgess' superior quality seeds, success depends largely upon cultivation, soil and weather conditions, so it is therefore agreed that in no case shall the Burgess Seed \& Plant Co. be liable for more than the original purcliase price.

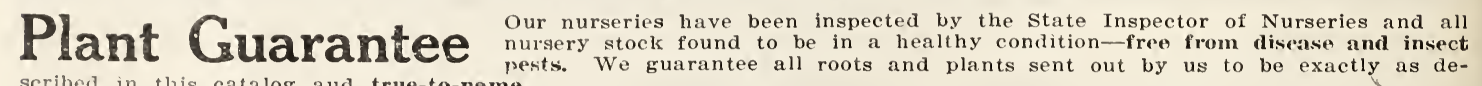
scribed in this catalog aud true-to-name.

Every customer is entitled to receive, in good condition, sound, healthy plants. We will replace without charge any stock that does not reach the purchascr in good condition or that is not free from injurious insects or disease, provided we are notified within five days of arrival of the plants and such stock is heeled in and held subject to our disposal. Tnless a customer reports within five davs after receipt of plants it is understood that the plants arived in a live and healthy cendition. It is not our fault if later the plants fail. The life of a plant after it reaches the planter depends upon conditions over which we have no control.

The chief causeg of failure after nursery stock is received are: Drying out in the sun or wind or freezing in the cold; failure to properly prume the roots and tops, crowding the roots into small holes cit out of the sod; planting in worthless soil: the use of too much fertilizer or placing of manure or fertilizer in direct contact with the roots; failure to tramn the soil firmly about the roots; drains; dogs; pests; children; heat; cold; accidents; wrong locations; lack of moisture; and lack of proper care and attention. No fair-minded customer wou'd ask for replacement when failure to grow is unquestionably due to sucls causes, but when the cause of faiture is unknown and the customer reports such loss by Augusi 1st following planting, we will replace such stock at one-half price.

Our methods of propagation and handling stock insure to the greatest extent the true labeling of our plants. It is mutually agreed. however, between the purchaser and ourselves that we are to be held liable for not more than the purchase irtce

Thls guarantee is the best protection to the planter that was ever offered by a responsible house. Demand this guarantee wherever and whenever you buy.

WE PAY THE POSTAGE, Express or Freight, to your town (anywhere in the world), Whe plants offered in this catalog except where otherwise stated.

Aways send kemittunce with Oader. Our terms are the same to all. Our business is done on a cash basis. This is a clirect bunefit to all our clistomers, as we are not compelled to increase our sellirg price to "*u in order to cover other people's bacl debts, and at our low prices we can't afford to open any accounts or fill C O D orders White we prefer that remiltances be made either by post office or express monev orter, bank draft or registered letter, we will, ior amounts of less than one dollar, accept clean postage stamps.

1RLMLx3E1:- We can not accept Canadian or foreign postage stamps, as we can not use them. 


\section{Burgess' Hardy Vegetable Seeds are the Best for All Climates}

The home-gardener and the commercial grower will find in our Vegetable Seed Department a list of the most dependable varieties - the best of both the old and new sorts. We do not offer as many varieties as some seedsmen, as we weed out the less desirable sorts, and offer only the best. We have endeavored to make selection easy by describing accurately and telling both the advantages and disadvantages of each sort.

The best test of a seed is the crop it produces. Burgess' Hardy Michigan Seeds have no superior.

We are supplying many of the most critical market-gardeners, in every State in the Union, with the best and purest strains of Vegetable Seeds. The steady increase in our market-garden trade each year, and the fact that the gardeners who began buying from us when we first started in business are still numbered among our best customers, is the best evidence that our seeds give satisfaction.

\section{Asparagus}

Asparagus grows better and produces earlier in the spring if planted in well drained soil having a southern exposure.

An ounce of good seed will produce about 250 plants; 2 lbs. for one acre.

GIANT WASHINGTON. A new variety developed by the United States Department of Agriculture. A rapid growing sort with a delicious flavor and tenderness, yielding stalks two inches in diameter, and even when twelve inches long are perfectly tender. It is practically immune irom "rust" and other Asparagus diseases and, is, without doubt, the finest strain of Asparagus now available. Pkt., 10c; oz., 20c; $1 / 4$ lb., 60c; 1b., $\$ 2.00$, postpaid.

PALMETTO. Another excellent variety and, with the exception of Giant Washington, is the nearest rust proof of any. It is a wonderful yielder, producing large, thick, dark green shoots, nearly as large as Giant Washington. Pkt., 5c; oz., 10c; $1 / 4$ lb., 30c; lb., $\$ 1.00$, postpaid.

COLCMBLA MAMMOTH WHITE. The best white sort; mammoth in size. Pkt., 5c; oz., 15c; $1 / 1 /$ lb., 40c; lb., \$1.25, postpaid.

\section{Prices of Asparagus Plants}

GIANT WASHINGTON. 12 for $50 \mathrm{c} ; 25$ for $75 \mathrm{c} ; 50$ for $\$ 1.25 ; 100$ for $\$ 2.00$; 250 for $\$ 4.50$, by parcel post, postpaid. By express, not prepaid, 500 for $\$ 7.00$; 1,000 for $\$ 13.00 ; 5,000$ for $\$ 60.00$.

PALMETTO. 12 for $35 \mathrm{c} ; 25$ for $50 \mathrm{c} ; 50$ for $80 \mathrm{c} ; 100$ for $\$ 1.50 ; 250$ for $\$ 3.50$, by parcel post, postpaid. By express not prepaid, 500 for $\$ 5.50 ; 1,000$ for $\$ 10.00 ; 5,000$ for $\$ 45.00$.

COLUMBIAN MAMMOTH White. Same price as Palmetto.

We always recommend one year old plants, as they are the best size for transplanting, make better plants, and come into bearing as soon as the twoyear old plants. We have, however, a limited number of two-year old plants which we can supply at the same price, as long as they last, to those who want them.

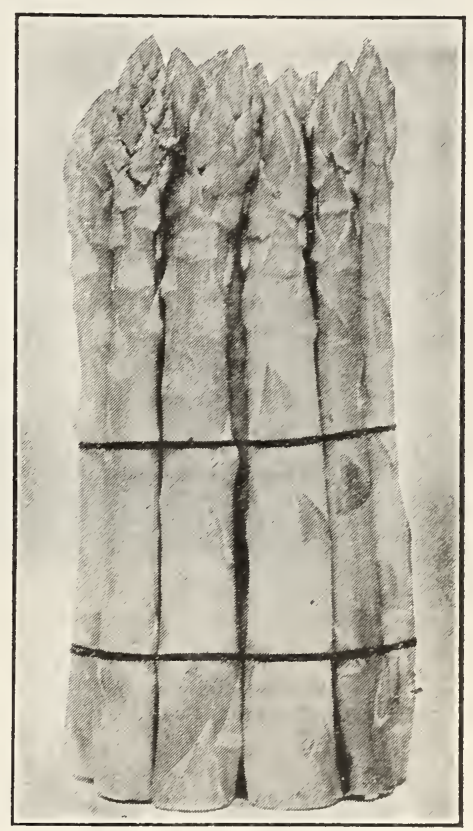

Giant Washington Asparasus

\section{What Our Bankers Say About Us}

\section{Galesburg State Bank Galesburg,Michigan}

November $12,1926$.

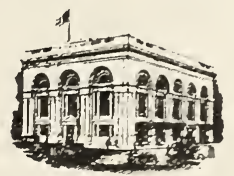

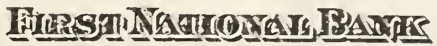

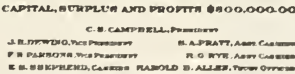

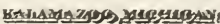
november 8,1926

To Thom 2t Uey Concern.

We take pleasure in stating that the Burgess Seed Plant Co. are valued depositors of ours and with whom we have had pleasant business dealings for the past fourteen years. No one need hes:tate about sending money to them, as they are responsible and rellable, and upright and straightforward in all their dealings.

To Thom 1 t May Conced

ve are pleased to state that the Burgese Seed \& Plant Co. of Galesburg, Nichigan has carried a very sut1 afactory account with un during the past three years. The manacement 1. capable and coneervative. They are well Inanced and In good credi

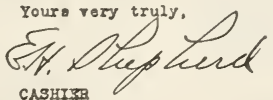




\section{Burgess' Michigan Grown Beans}

Every seedsman now concedes that Michigan Grown Beans are the best that can be produced. Our stock of seed is velected with extreme care, and the growing crops carefully rogued several times each season. The following list comprises the best of their respective types.

\section{DWARF WAX-PODDED BEANS}

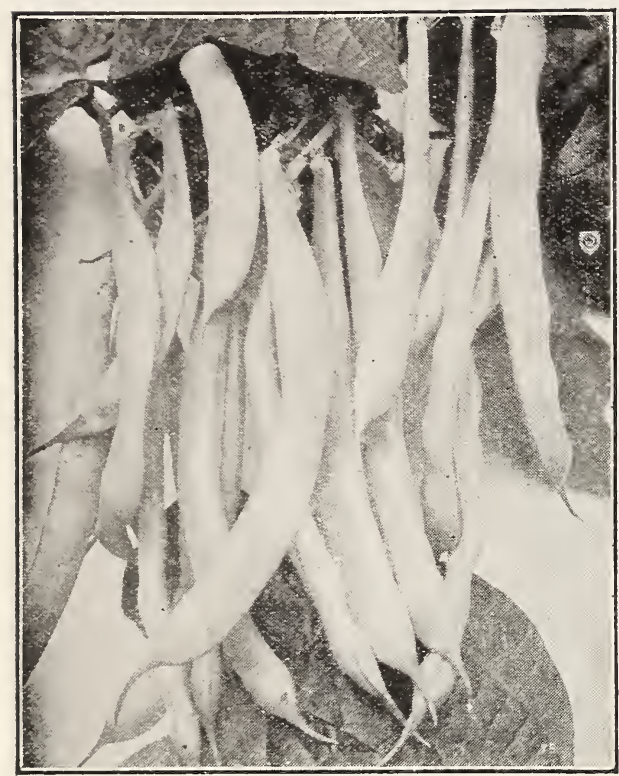

Early Wonder Wax
Early Wonder Wax

\section{EARLIEST WAX BEAN-RUST PROOF}

Early Wonder Wax belongs to the oval podded class and grows a strong plant, 18 inches $\mathrm{high}$ and 2 feet across. It is well loaded with pods, 5 to 7 inches long; flat, plump, handsome and meaty. of a clear, waxy yellow color. As to quality the pods are tender, brittle and of fine texture. This is the earliest wax-podded bean; ready to pick in 35 to 40 days. Practically rust-proof; a bountiful yielder, in bearing for a long season; an ideal bean for the home garden and a real money maker for the market gardener. Pkt., 10c; $1 / 2$ lb., 25c; lb., 45e; 2 lbs., 80c, postpaid.

DAVIS WHITE WAX. Medium-early. Eating quality not quite as varieties, but will bring a better price on the market, owing to its fine appearance. Pods about 6 inches long, very straight, waxy-white and handsome. Popular for canning, as the beans are pure white. Extensively used both as a snap bean and as a dry shell bean; fine for baking. Very productive. Pkt., $10 \mathrm{c} ; 1 / 2$ lb., 22c; 1b., 40c; 2 lbs., 70c, postpaid.

IMPROVED GOLDEN WAX. Medium-early; heavy cropper; pods of good length, oval and quite thick; clear, waxy, golden yellow color, and fine buttery flavor. P'kt., 10c; $1 / 2$ lb., 22e; 1b., 40c; 2 lbs., 70c, postpaid.

PROLIFIC BLACK WAX. An old, medium-early sort which retains its popularity on account of its excellent quality. Very tender, crisp, medium-long, yellow, round pods. Almost rust proof and crisp, medium-long, yellow, round pods. Almost rust proof and
very productive. Pkt., 10c; $1 / 2$ lb., 22c; lb., 40c; 2 lbs., 70c, postpaid.

WARDWELL'S KIDNEY WAX. One of the most desirable wax. beans for the home garden, and a great favorite with market gardeners on account of great productiveness and the large size, handsome appearance and fine quality of the pods. Golden yellow, of rich, luscious flavor and exceptionally brittle and tender. A week or ten days later than the medium-early sorts. Pkt., 10e; $1 / 2$ lb., 220; lb., 40e; 2 lbs., r0c, postpaid.

\section{DWARF GREEN-PODDED BEANS}

One pound of seed for 75 feet of row

\section{Bountiful}

FARLIEST GREEN POD BEAN AND A CONTINUOUS BEARER

This superior variety is of thrifty growth, very hardy and practically rust and mildew proof. It bears continuously for several weeks, being the first to give pods itt to pick in the spring and the last to yield edible pods in the fall. Under favorable conditions of soil and season this variety has been known to bear one bushel of pods per 15 foot row, in the course of the season. The large green pods are thick, broad, flat, extra long, very uniform in shape, solid, meaty, and of high quality, tender, of delicious flavor and absolutely stringless. Ready for picking in 38 to 42 days. Pkt., 10e; $1 / 2$ lb., 25e; lb., 45e; 2 lbs., 80e, postpaid.

BURPEE'S STRLYGLESS GREEN POD. An extra early, roundpodded, prolific sort, bearing abundantly, long, bright green, stringless pods of excellent quality. Pkt., 10e; $1 / 2$ lb., 22c; lb., 40c; 2 lbs., 70c, postpaid.

\section{SPECIAL PRICES Tor Market Gardeners and} 77 and 78 .

TNOCTI ATE Your Bean Seed for best results. Hastens maturity, increases the will always be used. It is not an expense, but an investment. Price, Garden Size, sufficient for 5 lbs. of seed, 25c, postpaid.

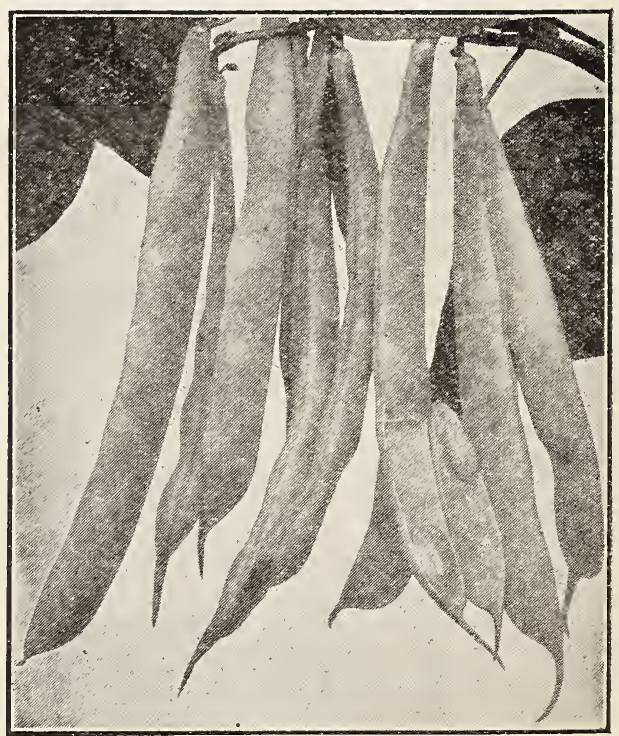

Bountiful 


\section{Full Measure}

Full Measure is decidedly the best round podded, stringless, dwarf green bean in existence, and on account of its superior quality, it is especially desirable for the home garden. It begins to bear with the second-early sorts, the heavy pods producing throughout a long season. Very productive; pods average 6 inches long, fleshy and absolutely stringless. Plkt., 10c; 1/2 1b., 25̃c; lb. 45c; 2 lbs., 80c, postpaid.

REFCGEE OR 1000 TO 1. The latest of the green podded beans, the most vigorous in growth, and one of the most productive. For mild, rich flavor no dwarf bean can surpass it. Stringless when just fit to eat; afterwards quite stringy. A favorite for market and canning purposes. Pkt., 10c; 1/2 1b., 22c; lb., 40c; 2 lbs., 75c, postpaid.
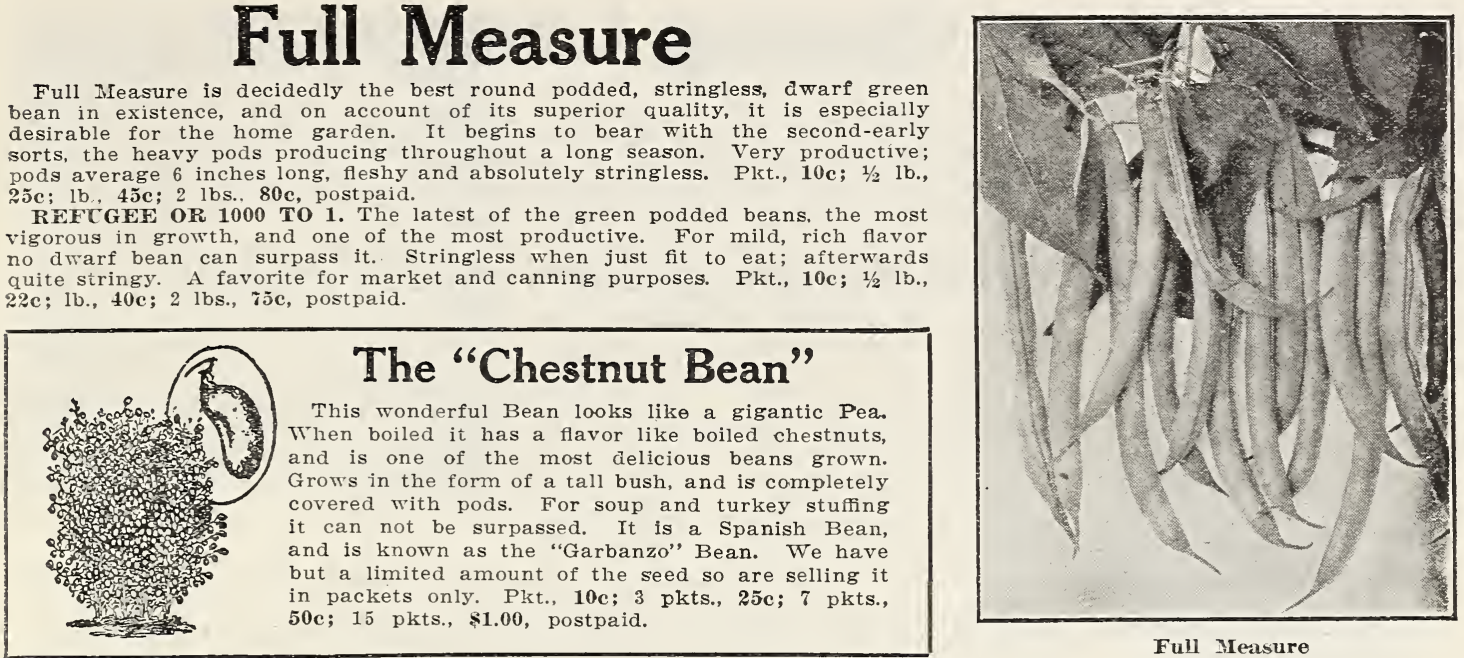

Full Measure

\section{BUSH LIMA BEANS}

One pound of seed for 100 feet of row

BCRPEE'S IIPROFED BCSH. The largest of all Bush Limas, bearing pods almost equal in size to those of the large Pole Limas. Pods 5 to 6 inches long by $1 \frac{1 / 4}{1}$ inches wide and the full size beans are of luscious flavor. Pkt., 10c; 1/2 lb., 30e; 1b., 50c; 2 lbs.. 95 c; postpaid. FORDHOOK. Nearly as large as Burpee's Improved and about a week earlier. Extremely prolific. with large, thick, meaty Beans of delicious quality. Pkt., 10c; 1/2 lk., 30c; 1b. 50c; 2 lbs, 95 c, postpaid.

HENDERSON'S BUSH. The earliest Lima grown and continues to produce until killed by frost. Will produce an abundant crop under a wider range of weather and soil conditions than any other Lima. Beans are not large, but the quality is excellent. Pkt., 10c; $1 / 2$ lb., 25̃e; lb., 45e; 2 lbs., 85̃e, postpaid.

SPECIA OFFER One packet of each of the above three varieties postpaid.

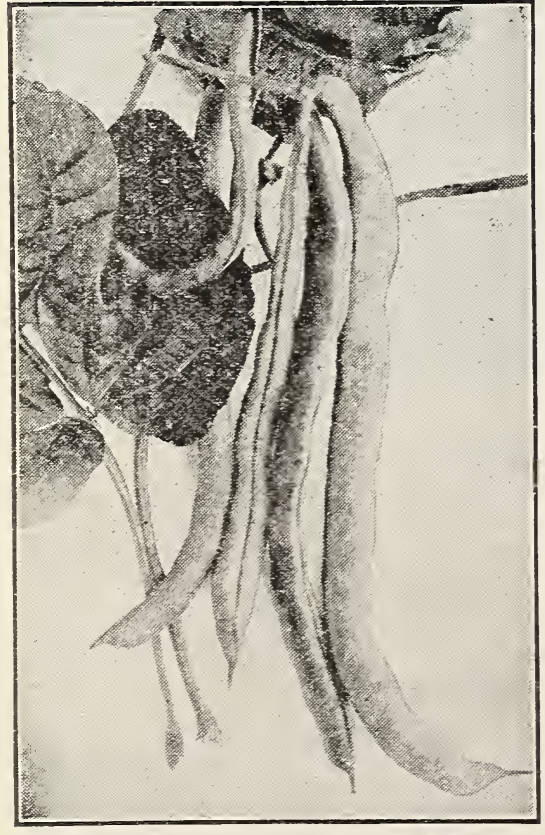

Burgess' Ererbearing Kentucky Wonder

\section{POLE OR CLIMBING BEANS One pound of seed for 100 poles \\ Burgess' Everbearing Bean}

Burgess' Everbearing or Everbearing Kentucky Wonder is without exception the finest flavored snal bean grown. The green pods, seven to ten inches long are so fleshy they are often greater in thickness than width. They are solid, meaty, and very crisp. They commence bearing exceedingly early for a pole or climbing sort, and if pods are gathered as they mature the vines will continue to bear until killed by the fall frosts. This is one of the few pole beans that will bear a satisfactory crop without being poled. It will not produce as large a crop if grown without poles but will be more productive than any of the dwarf sorts. By planting a few hills in your corn, the corn stalks will act as a support for the vines, and you will get a good crop of both corn and beans. Pkt. 10c; $1 / 2$ lb., 30c; lb., 50c; 2 lbs., 90c, postpaid.

SCARLET RUNNER. A fine ornamental vine, bear ing large sprays of bright scarlet pea-like flowers and abundance of edible beans. Used both for shell and snap beans. Pkt., 10c; 1/2 1b., 30c; lb., 50c, postpaid. Yard Long Bean This is an excellent variety, curiosity. The vines are rampant growers and produce an enormous crop of long, slender, round pods which are of excellent quality for snap beans. The round pods are from 2 to 4 feet in length, having the thickness of a lead pencil. Produce late in the summer, very productive, tender and of fine flavor. Pkt., 10c; 3 pkts, 25c; 1/4 lb., 50c; lb., \$1.5̃0, postpaid.

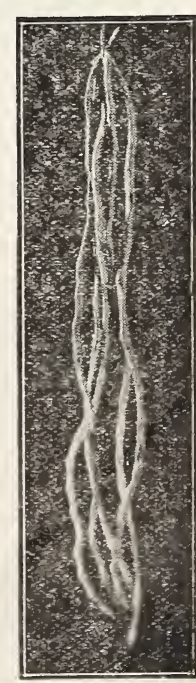

Yard Long 


\section{Pole or Climbing Lima Beans}

One pound of seed for 50 poles.

EARIX LEVIATHAN. Fully a week earlier than any other Pole Lima; a sure cropper and extremely productive, both early and throughout the season. Pods straight and long and well filled with large, thick beans of delicate pale green color and of a delicious buttery flavor. Pkt., 10c; 1/2 Ib., 30c; lb., 50c; postpaid.

KING OF THE GARDEN. A vigorous grower, requiring but two vines to each pole. Begins fiowering early, at the bottom of the pole, producing a continuous bloom and fruitage throughout the season. Pods are large and beans are of excellent quality, well-formed and mammoth in size. Pkt., 10c; 1/2 1b., 30c; 1b., 50c, postpaid.

\section{BURGESS' MICHIGAN GROWN FIELD BEANS}

Sixty pounds will plant an acre.

MICHIGAN MPROVED PEA OR NAVX. No other farm crop has seen such a great advance in price as Beans. It is one of the greatest money-making crops for those growers who have the foresight to plant selected pure seed, as they are receiving a good substantial premium over the ordinary mixed white beans that are still grown by so many farmers. The Afichigan Improved Pea or Navy is the greatest Bean for a farm crop that we have ever seen. Side by side with any bean known to us, our improved strain will yield fully one-third to one-half more.
The pods are large and filled with medium-sized, pure white, nearly round beans, which excel in cooking qualities. It is very early, having dry beans in 80 days from planting. It is an upright grower, holding the pods well up from the ground. The pods grow in thick clusters and ripen in August, the leaves falling earlier than other varieties. No other bean approaches it in yield, quality, and readiness to find sale on the market. Pkt., 10c; 1/2 lb. 20c; lb., 35c, postpaid. For prices in quantities, by express, see page 76.

\section{For Best Results with Beans, inoculate your seed. Hastens maturity, increases the yield and enriches} the soil. Garden Size, sufficient for 5 lbs. of seed, and good for Beans, Peas and Sweet at these same prices.

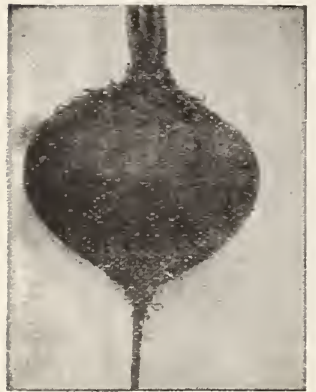

C'rosby's Egyptian Beet

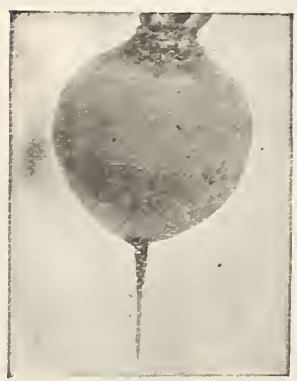

Netruit Dark Red Beet

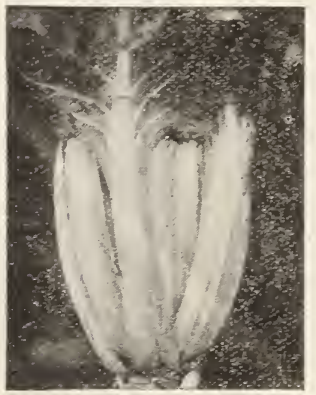

Spinach Beet

\section{BEETS-Table Varieties}

\author{
One ounce of seed to 50 feet of row.
}

CRosby'S EGYPTIAN. (Selected Strain). The best extra early variety. The skin to very smooth and bright red; flesh vermilion, very sweet and tender. A money-maker for market growers. Pkt., 8c; oz., 12c; 1/4 lb., 35c; 1b., \$1.00, postpaid.

DETROIT DARK RED. The best main crop variety, and the roots can be used early in the season when only partially grown, being ready for use almost as quickly as tlie extra early sorts. Form globular or ovoid; smooth and regular in form, with small taproot and free from rootlets. Flesh is fine grained, tender and sweet. Retains its choice quality and freedom from woodiness until the beets attain their full size. A favorite for canning because of its rich extra deep dark red color. Pkt., 8c; oz., 12c; 1/4 lb., 35c; 1b., \$1.00, postpaid.

EARIY BLOOD TURNIP. An exceedingly popular, early, round, deep-red beet of excelent quality. Pkt. 5c; oz., 10c; $1 / 1$ lb., 30c; lb., 90c, postpaid.

EARI.Y ECLIPSE. Early, roots globular in shape, flesh fine-grained, very sweet, crisp and tender; bright red, zoned with a lighter shade. The tops are small, admitting close planting. Pkt., 5e; oz., 10c; $1 / 4$ lb., 30c; lb., 90c, postpaid.

LONG SHOOTH BLOOD. The leading variety for winter use. Good sized, long, tapering, smooth roots; dark red; sweet and tender, remaining so until spring. Pkt., 5c; oz., 10c; $1 / 4$ lb., 30e; lb., 90e, postpaid.

SPIXACH BEET (IMPROVED MAMMOTH SWISS CHARD). Grown extensively for its large, juicy, tender leaves and leaf stalks. The leaves grow to a length of 2 to $2 \frac{1}{2}$ feet, and the stalks are nearly as thick and broad as Rhubarb and never get tough. By picking off the large outside leaves, as wanted, more leaves continue to grow and keep right on growing until killed by severe frost in the fall. The whole leaf can be used for greens, or the leaf stalks can be cooked like asparagus. P'kt., 8c; oz., 12c; 1/4 lb., 35c; lb., \$1.00, post paid.

\section{Sugar Beets and Mangel Wurzels}

Mangels and Sugar Beets are very important crops, furnishing a tremendous yield per acre of a very healthy and nutritious food that is greatly relished by all kinds of livestock. Will keep cattle in perfect physical condition and increase the flow of milk. As a substitute for green feed for poultry, during the winter months, they are very valuable and always increase egg production.

Yields of 25 to 35 tons per acre are common, and as high as 75 to 80 tons have been reported. The seed should be sown thinly in rows 2 to 3 feet apart, and when plants are about 3 inches high thin out to stand 8 to 10 inches apart in the row. Harvest before frost and store in pits outdoors or in a dry, frost-proof cellar.

One ounce of seed to 100 feet of row; 5 or 6 lbs. per acre.

GIANT HALF SUGAR. A favorite with many dairymen. Flesh white, sugary and of high nutritive value. Yields a tremendous crop. Pkt., 5e; oz., 8e; 1/1 lb., 20c; 1b., 65c, postépaid.

GOLDEX TANKARD. A rapidly maturing Mangel, adapted to shallow lands, although doing well on every soil. An immense yielder. Rich golden skin; flesh yellow. Easily harvested; excellent keeper. Pkt., 5c; oz., 8c; 1/4 1b., 20c; lb., 65c, postpaid.

FLELN WANZLEBEN. Practically all the leading authorities on Sugar Beets have united in recommending this variety as possessing the highest sugar producing qualities, as much as 18 tons of sugar having been made from 100 tons of roots. Also highly recommended for stock feeding. An enormous yielder. Pkt., 5e; oz., 10c; 1/4 lb., 25e; lb., 70c, postpaid.

MAMIOTH LONG RED. The largest and the heaviest cropper of all Mangels. The roots 作 harvested. Skin bright red; flesh white, veined pink. Keeping qualities not excelled. Pkt. 5e; oz., 8c; $1 / 4$ lb., 20c; lb., 65c, postpaid. 


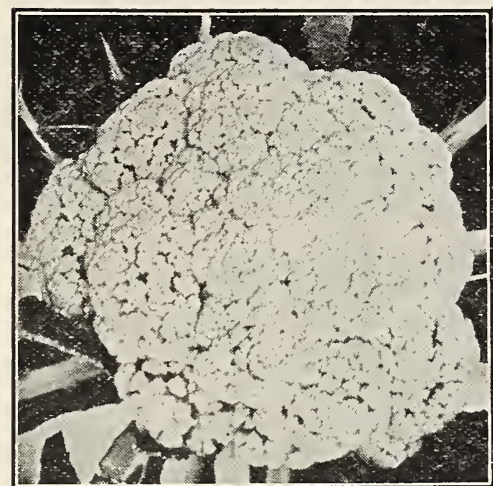

Early Purple Cape Broceoli

\section{Broccoli}

\section{(HARDY OR WINTER CAULFLOWER)}

This is a vegetable very similar to Cauliflower, but hardier and more easily grown, so will be found very valuable in those sections where the Cauliflower does not do well. Cultivate and use same as Cauliflower. One ounce will produce about 1500 plants.

EARIX PURPLE CAPE. The hardiest variety. Heads of medium to large size, creamy-white, tinged with purple; delicate flavor. Plkt., 10c; 3 pkts., 25c; oz., 50c; postpaid.

\section{BRUSSELS SPROUTS}

A variety of the Cabbage family, possessing the peculiarity of bearing upon its stem or stalk from 50 to 100 small, compact, round heads, each measuring from 1 to 2 inches in diameter. These heads are cut off when well formed and are usually marketed in quart berry boxes. The plants are very hardy, are not injured but improved by hard frosts, and are left in the garden or field during the early winter until wanted. May be had in fine condition until about. Christmas time in the North, and in the South may be had from November to March. These miniature Cabbages may be boiled like Cabbage or cooked in cream like Cauliflower. They are the most delicious and delicately flavored of the Cabbage family.

One ounce of seed for 200 feet of row.

MTPROVED HALF DWARF. The best variety for all localities; very productive. Pkt., 10c; oz., 25c; $1 / 4$ lb., 75c, postpaid.

\section{Cauliflower}

One ounce of seed will produce 2,000 plants

EARIX SNOWBALL. Our select strain of Early Snowball is the earliest Caulifiower grown. A very reliable heading variety with rich, snow-white, close, compact head of

the very best quality. Pkt., 15c; 1/4 oz., 70c; 1/2 oz., \$1.25; oz. \$2.25; 1/4 lb., \$7.50, postpaid.

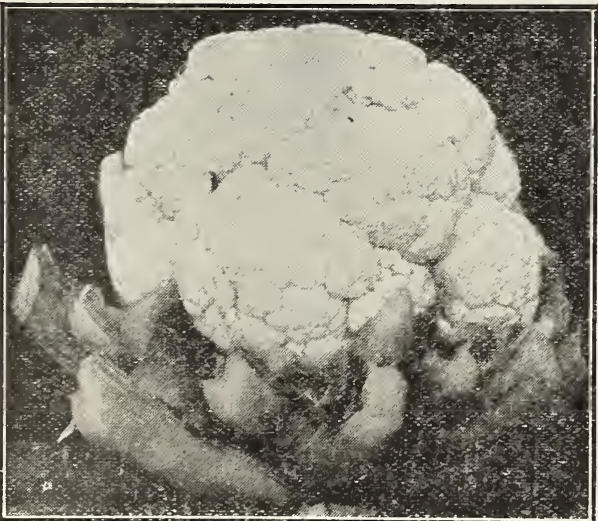

Early Snowball

EXTRA EARLY DWARF ERFURT. An excellent early variety. A little later than Early Snowball, but larger. Pkt., 10c; 1/s oz., $60 \mathrm{c}$; $1 / 2$ oz., $\$ 1.00 ;$ oz., $\$ 1.80 ; 1 / 4 \mathrm{lb}$., $\$ 6.00$, postpaid.

DRY WEATHER. A large second-early variety, producing immense compact heads of the very best quality. Will grow and head in hot, dry districts where it is difficult to grow other varieties. Extra select seed. Pkt., 15c; 1/4 oz., 75c; 1/2 oz., \$1.35; oz., $\$ 2.50 ; 1 / 4$ lb., $\$ 8.50$, postpaid.

VEITCH'S AUTUMN GLANT. A very large, late variety producing quite compact white heads. Like all late varieties, it is not nearly so reliable as the early sorts except in cool sections. Pkt., $8 \mathrm{c}$; $1 / 2$ oz., 40e; oz., 70c; 1/4 lb., \$2.35, postpaid.

\section{COLLARDS}

A form of loose-headed cabbage that usually succeeds in locations where other sorts of cabbage cannot be grown to perfection. In the South they continue to grow all winter lons and the tender tops are cooked like ordinary Cabbage, which they resemble greatly in flavor.

One ounce of seed for 400 fect of row.

GEORGIA. The leading and best variety. Pkt., 5c; oz., 15e; 1/4 1b., $40 \mathrm{c} ; 1 \mathrm{~b} ., \$ 1.25$, postpaid.

\section{CHERVIL}

One ounce will sow 100 feet of row

EXTRA FLNE CURLED. A hardy annual with aromatic leaves somewhat resembling, but more beautiful than Parsley, and by many considered superior to it in flavor. The young leaves are used in soups and salads and for garnishing meats and vegetables. Pkt., 10e; oz., 25e; $1 / 4$ lb., 75e, postpaid.

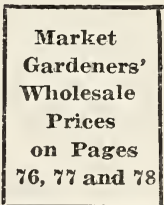




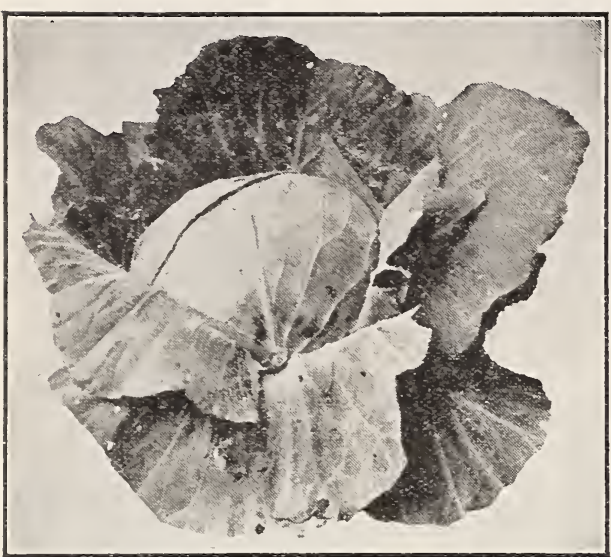

Copenhagen Market

\section{Cabbage}

In growing a profitable crop of Cabbage, much depends upon the seed planted. Our seed is all carefully grown from selected heads and under the supervision of expert cabbage seed growers. You can place an order for our seed with the assurance that you are getting the best that money can buy.

One ounce of seed for 2,000 plants; $1 / 2 \mathrm{lb}$. per acre.

\section{Lightning Express}

THE EARLIEST CABBAGE IN CULTIVATION

Our Lightning Express is ready for use in 65 to 70 days from sowing-ten days earlier than Jersey Wakefield. Good fair trials of varieties offered by other seed houses as "the earliest grown" have proved that they are from 4 to 10 days later than our Lightning Express. Lightning Express is positively the earliest Cabbage in cultivation. Heads pointed, of good size, a little smaller than Jersey Wakefield, always sure to head, solid and firm and always in demand on the marlet, bringing high prices on account of their extreme earliness. Very hardy, permitting earliest planting. There are but few outer leaves and the plants may therefore be set closely together. As many as 14,000 heads can be grown on one acre of ground, and will bring a larger profit per acre than later and heavier varieties. Pkt., 10c; oz., 40c; 1/4 lb. $\$ 1.25 ; 1 \mathrm{~b} ., \$ 4.00$, postpaid.

FARLY JERSEY WAKEFIELD. Our Special Stock. The most popular early cabbage. About ten days later than our Lightning Express, but has larger heads and is more productive. Heads conical or pointed, solid and of the very best quality. Pkt., 5c; oz., 30c; $1 / 2$ lb., 90c; lb., $\$ 3.00$, postpaid.

CHARLESTON, OR LARGE WAKEFIELD. About a week later than early Jersey Wakefield. Heads are larger, fully as solid, and a little less pointed. An excellent variety to closely follow Early Jersey. Pkt., 5c; oz., 35c; 1/t lb., \$1.00; lb., \$3.50, postpaid.

EARLY WINNIGSTADT. About the same season as Charleston Wakefield. Heads pointed, medium size and solid. A popular sort for the garden, as it remains in good condition for a long time. Plit., 5c; oz., 30c; $1 / 4$ lb., 90c; lb., \$3.00, postpaid.

\section{New Golden Acre}

\section{EARLIEST ROUND HEAD CABBAGE}

Our special strain of this wonderful new Cabbage will mature hard, round heads, nine inches in diameter, of five pounds each, in 70 to 75 days from time of sowing seed. Uniform in size and growth; compact in habit, with few outer leaves, permitting close planting. The heads are firm and solid and fully equal to any of the late sorts, and will stand in the field for a month or more without bursting. The most profitable variety to raise for the early market. Pkt., 15c; 2 pkts, 25c; oz., 70c; $1 / 4 \mathrm{lb}$., \$2.25, lb., \$7.50, postpaid.

\section{Copenhagen Market}

One of the most valuable varieties for the home garden and one of the most profitable for market gardeners. With the exception of Golden Acre, it is the earliest roundheaded Cabbage. In season it ranks with Early Jersey Wakefield, which it will outyield two to one in weight of crop on a given area. When ready for cutting, Copenhagen Market is the heaviest of the extra-early varieties and is as good, in its class, as the old favorite Danish Ballhead. The stem is short; the head is round and solid, averaging 8 to 10 pounds each, and uniform in shape and size. A vigorous grower and an excellent keeper. The heads all mature at one time, and will stand longer without bursting than other early sorts. Many large growers consider Copenhagen Market as the best of all early cabbages. Fkt., 10c; oz., 35c; 1/4 lb., \$1.00; lb., \$3.50, postpaid.

GLORY OF ENKHUIZEN. Ten days later than Early Jersey Wakefield, but heads twice as heavy. Grows large, solid, round heads with few outer leaves, and such compact growth as to permit close planting. When trimmed, heads weigh from

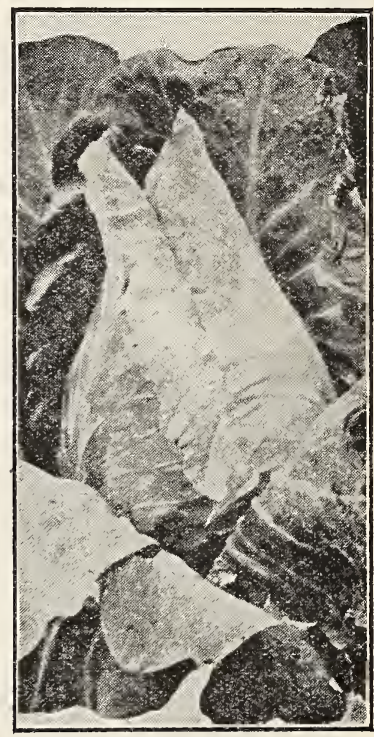

Lightning Express 6 to 8 pounds and are similar in appearance to a small Danish Ballhead. Size ideal for marketing; quality the very best; excellent keeper. Plit., 5c; oz., 30c; 1/4 lb., 90c; lb., \$3.00, postpaid.

ALL-HEAD EAPLY. The largest flat-headed early cabbage. Very popular early variety; also popular for later planting for winter use, Excellent quality; good keeper. Pkt., 5r: oz., 35c; 1/4 lb, \$1.00; lb. \$3.50, postpaid.

EARZY DWVAR FLAT DUTCH. An excellent large second-early flat variety, producing solid heads that mature much earlier than Late Flat Dutoh. Pkt., 5c; oz., 30c; $1 / 4 \mathrm{lb}$., $90 \mathrm{c}$; lb., \$3.00, postpaid.

SUCCESSION. Intermediate between the Early Flat Dutch and the Late Flat Dutch. The heads are large and flattened and run uniform in size and shape; solid, and are of splendid quality. Its great productiveness, sure cropping and long keeping qualities make it one of the best for general use. Pkt., 5c; oz., 30c; 1/4 lb., 90c; lb., \$3.00, postpaid.

ALI. SEASONS. Large heads, round, flattened at top; extremely hard and solid; a sure header. A leading variety for kraut. Good for autumn or winter use as well as for early summer. Pkt., 5c; oz., 30c; $1 / 4$ lb., 90c; lb., \$3.00, postpaid.

PRERIUM LATE FLAT DUTCH. A most popular large flat, late variety; quality unsurpassed. Pkt., 5c; oz., 35c; $1 / 4$ lb., $\$ 1.00 ; 1 \mathrm{~b} ., \$ 3.50$, postpaid. 


\section{Danish Ballhead}

(TALL STEM)

The most popular cabbage for winter; very fine grain, tender and crisp. The heads are medium sized, round, and so hard and solid that they will weigh one-fourth more than other varieties of equal size, and will stand shipping better than other sorts. It is not necessary to dispose of the crop in the fall if market prices are not satisfactory. The crop can be stored just as safely as potatoes, and they will be just as solid in the spring as when put away in the fall. Especialiy recommended for the Northern States. Pkt., 5c; oz., 30c; $1 / 4$ lb., 90c; lb., $\$ 3.00$, postpaid.

\section{Danish Roundhead}

(SHORT-STEM BALLIEAD)

A short stemmed type of the well known and much prized Danish Ballhead Cabbage. Danish Roundhead has all the desirable qualities of the Danish Ballhead, heads of the same size, as round as balls and as solid as bullets. Fully two weeks earlier and will keep and ship as well as Danish Ballhead. Pkt., 5c; oz., 30c; 1/4 lb., 90c; lb., \$3.00, postpaid.

SCREHFAD. One of the best late cabbages, of the Flat Dutch type, weighing ordinarily from 10 to $15 \mathrm{lbs}$. each. Of very fine quality, solid, and of fine texture. Drought resisting, about 10 days earlier than Danish Ballhead and certain to head. Grown extensively for winter use and one of the best keepers. We recommend Surehead for the home garden. Pkt., 5c; oz., 30c; $1 / 41 \mathrm{~b}$. $90 \mathrm{c} ; 1 \mathrm{~b} ., \$ 3.00$, postpaid.

JCMrBO. The largest cabbage grown; 20 to 30 pounds each. Heads flat, rounded at top: very solid; sure to head; excellent keeper. The quality, for slicing, for kraut and for general table use is unsurpassed. Pkt., 10c; oz., 40c; 1/4 lb., \$1.25; 1b., \$4.00, postpaid.

HAMMOTH ROCK RED. The largest and the very best red variety. Pkt., 5c; oz., 30c; 1/4 lb., 90c; lb., \$3.00, postpaid.

AMERICAN DRUMIIEAD SATOY. The Savoys excel all other cabbages in flavor, and our improved strain of American Drumhead is the best of the Savoys Crimped leaves; more tender, milder, and sweeter than the smooth-leaved varieties. No garden complete without this wonderful cabbage. Pkt., $10 \mathrm{c}$; oz., $35 \mathrm{c} ; 1 / 1 \mathrm{lb}$., $\$ 1.00 ; 1 \mathrm{~b} ., \$ 3.50$, postpaid.

\section{Chinese Celery Cabbage}

A most delicious vegetable which combines the rich celery flavor with that of the cabbage. Can be cooked or eaten raw like celery. Makes as good salad as the finest head lettuce. The mid-ribs can be cooked like asparagus, and for cold slaw no cabbage compares with it. One of the most delicious vegetables yet introduced, and bound to become one of the most popular. Pkt., 10c; oz., 25̃c; 1/2 lb., 75c; lb., \$2.50, postpaid.

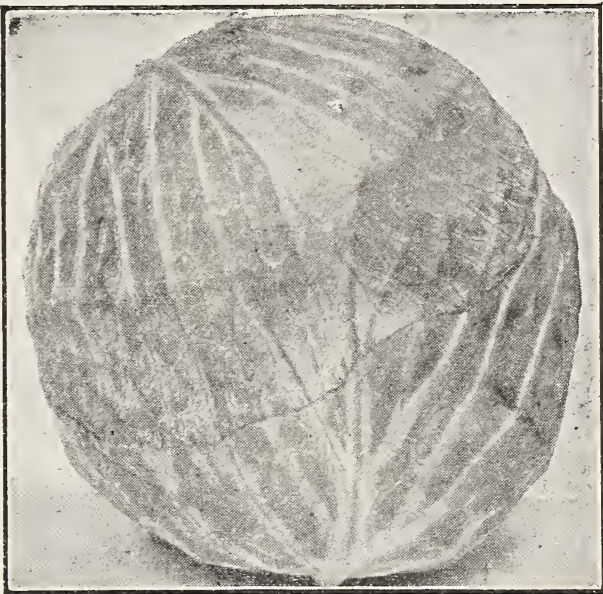

Danish Ballhead

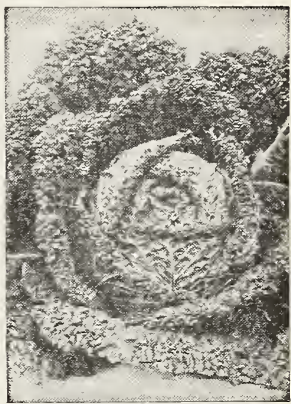

American Drumhead Savoy

\section{Burgess' Frost-Proof Cabbage Plants}

Our Frost Proof Cabbage Plants mature heads 2 to 3 weeks earlier than home grown plants and double your profit. These plants are grown for us in the open field in the South, where the soil and climatic conditions are just suited for growing tough, hardy cabbage plants during the winter and early spring. The plants make a slow but steady growth, until at 8 to 10 weeks of age they are very tough and hardy, the buds are purple and the outer leaves reddish brown. When in this condition they can be shipped to territory farther north and should be planted in the open ground a month or six weeks sooner than the home grown hot bed or cold frame plants. These FrostProof Cabbage Plants will stand a temperature of 20 degrees above zero. The plants when received will be somewhat wilted and have a

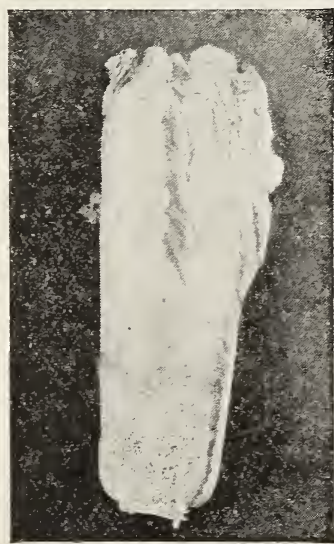

Chinese Celery Cabbage stunted appearance, which will be disappointing to persuns who have never used these plants before. Regardless of appearance, they will produce the crop results. You know what the difference in profit will be if your crop is matured and marketed before the general crop from home grown plants is ready. We offer the following varieties only:

Early Jersey Wakefield, Charleston Wakefield, Copenhagen Market, Succession and Early Dwarf Flat Dutch. These plants can be supplied by us from December 1st to May 1st, only.

PRICES: 100 plants for $75 \mathrm{c} ; 200$, $\$ 1.35 ; 300, \$ 1.85 ; 400, \$ 2.30 ; 500$, \$2.75; 600 or more, 50c per $100 ; 1,000$ or more, 4 č per 100 , by parcel post, postpaid. $\mathrm{No}$ order filled for less than 100 plants. These prices are for even hundreds of one variety. If you order 200 of one variety and 300 of another you would pay at the 200 and 300 rate; not the $50: 0$ rate. Order early and give date you want plants shipped.

\section{Market Gardeners}

SEE PAGES $\% 6,7 \%$ AND $\% 8$ AND

SATE MONEY

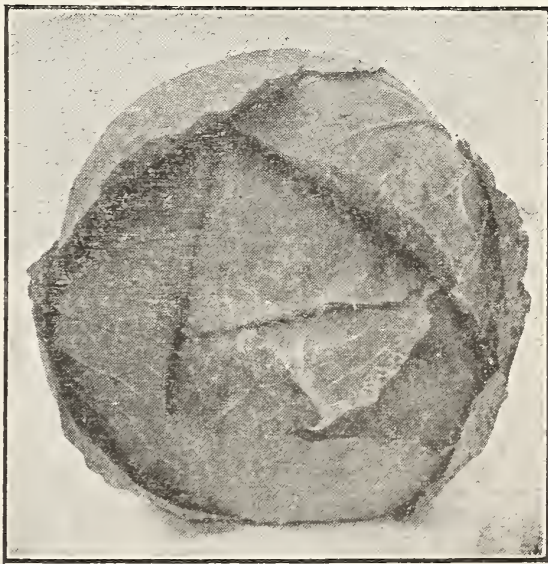

Jumbo 


\section{Burgess' Michigan Grown Sweet Corn}

We take pride in our select strains of Michigan Grown Sweet Corn, which is from five to ten days earlier than the same varieties produced farther south or west. This means a great deal to the gardener who wishes to have his corn first on the market, for it is then that the best prices are obtained. Michigan Sweet Corn is also noted for its sweetness, being much sweeter than Western corn. Our prices of Sweet Corn are a little higher than those charged by some seedsmen who handle Western seed, but the extra price you will pay is a most profitable investment. No matter where you live, your best assurance of an extra early crop of Sweet Corn of the best quality is to plant carefully grown Michigan seed. Our seed will meet the requirements of the most critical market garden trade.

One pound for 150 hills; 12 to 16 lbs. per acre.

\section{Early Saskatchewan}

\section{THE EARLIEST VARIETY OF SWEET CORN}

A new introduction and the earliest Sweet Corn in cultivation. Not only that, but the quality is superior to that of most varieties of extra early Corn. It is extremely hardy, withstanding cold, wet weather to a wonderful degree, and can be planted nearly as early as the early Peas. Ears are of good size for so early a variety; kernels pure white, sweet and tender. It is also very productive for an extra early sort, usually producing two ears to the stalk. We can highly recommend this variety for home use, and as a market sort it is a money maker. Pkt. 10c; $1 / 2$ lb., 22c; lb., 40c, postpaid.

EARLY MAYFLOWER. One of the whitest and sweetest of the early varieties. Ready for the table a few days following Early Saskatchewan and earlier than the Mammoth White Cory. We have discontinued growing the different strains of Cory as we have found Early Mayflower to be superior in every way-earlier, sweeter, more tender and of better table quality. Ears 6 to 8 inches in length; an exceptionally good yielder. We r.commend this variety to come in between Early Saskatchewan and our Improved Golden Bantam. Pkt., 10c; 1/2 lb., 20c; lb., 35c, postpaid.

MMPROVED GOLDEN BANTAM. The most popular early Sweet Corn; the sweetest, the richest flavored and the most delicious early variety. In season it closely follows Early Mayflower. Ears 5 to 7 inches in length and compactly filled with kernels which, when ready for the table, are of a creamy-yellow color. Golden Bantam is suited for extra early and later plantings up to July $15 \mathrm{th}$. Our stock of this splendid home garden and market variety has been carefully selected and is decidedly superior to much that is offered. Pkt., 10c; $1 / 2$ lb., 20c; lb., 35e, postpaid.

DE LUE'S GOLDEN GIANT. As good to eat as Golden Bantam; only 4 or 5 days later, but with ears 50 to 75 per cent larger. The cob contains 16 to 18 rows, which completely cover the entire surface. On account of the size of the ears it is a more profitable variety than Golden Bantam for the market gardener to grow. Another notable feature is its heavy husk, which protects it from ravages of birds and worms. Pkt., 10c; 1/2 lb., 22c; 1b., 40c, postpaid.

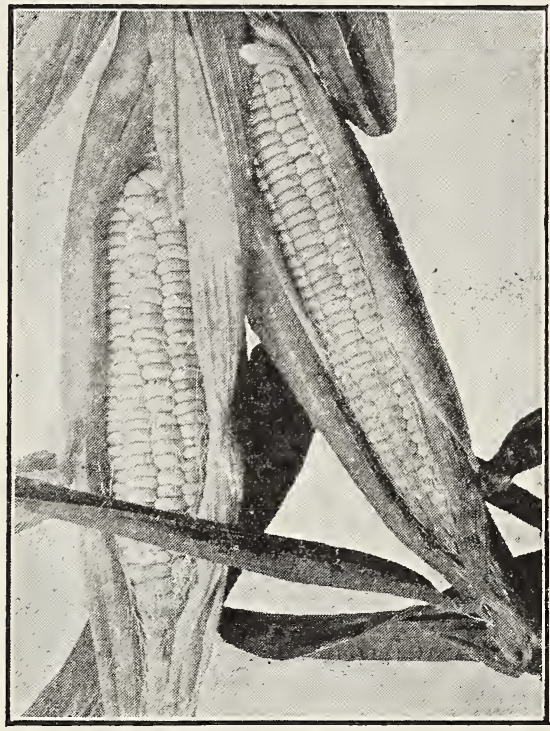

Saskatchewan

\section{GOLDEN EVERGREEN}

THE BEST MALN CROP VARIETY

This new variety is the result of a cross between Stowell's Evergreen and Golden Bantam, possessing all the splendid qualities f both of these popular varieties and better than either. It is the finest and sweetest corn ever introduced. qualls Evergreen and is of true Evergreen habit, remaining equally as long a time in good cooking condition. It is of the same color as Golden Bantam, and has all the delicious quality of that variety, with an
added sweetness and superior flavor. About 5 days later than De

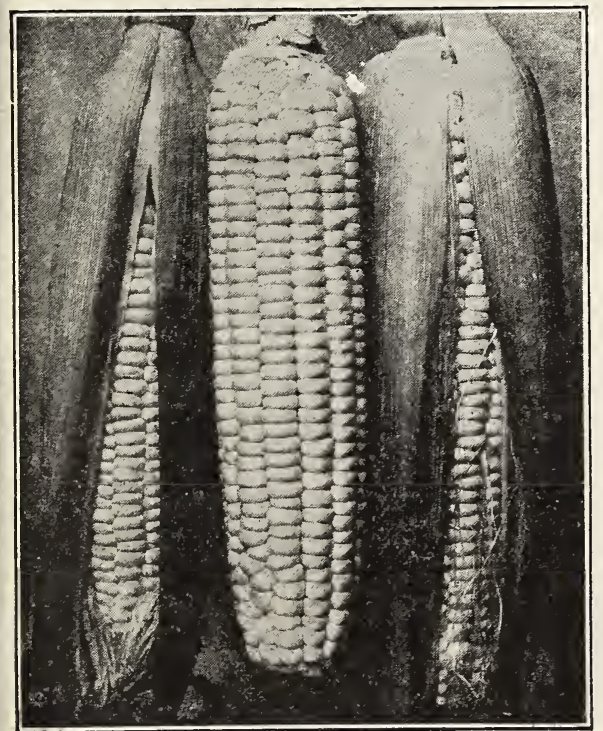

New Galden Evergreen Sweet Corn Lue's Golden Giant, or half way between Golden Bantam and Sto-
well's Evergreen. For the home garden and fancy market trade this crn has no of it this season. Pkt., 10c; $1 / 2$ lb. 22 c; lb., 40c, postpaid.

STOWELL'S EVERGREEN. The standard main crop variety in all sections. Michigan grown Stowell's Evergreen is recognized everywhere as the best type of its class. Our strain is large eared, hardy, productive, sweet and tender, and remains a long time in cooking condition. Pkt., 10c; 1/2 lb., 20c; lb., 35c, postpaid.

COUNTRY GENTLEMAN. The finest and sweetest of all white ( the kernels on the cob. Excellent sort to grow where worms bother the ears, for instead of working a row into the center of the ear, they have no row to follow, and work around the end of the cob. Very prolific, rarely producing less than three ears to the stalk. Ears average 8 to 9 inches in length and grain is very deep. Has delicious flavor all its own, and no garden is complete without it. A week later than Stowell's Evergreen. Pkt., 10c; 1/2 lb., 22c; lb., 40c, postpaid.

\section{SPECIAL ALL SEASONS COLLECTION}

The seven varieties described on this page, when planted at the same time, will produce a continuous supply of Sweet Corn from early summer until frost. One packet each of the seven varieties, 50c; $1 / 2 \mathrm{lb}$. of each, $\$ 1.25$, postpaid.

MARKET GARDENERS and others using seed in quantity can save money by consulting pages 76,77 and 78 of this catalog. 


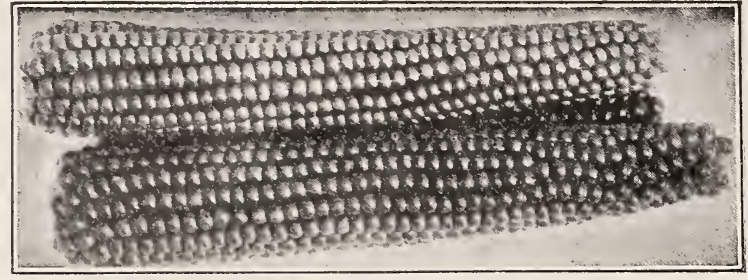

Black Beauty Pop Corn

\section{Pop Corn}

Four pounds of seed to the acre.

AUSTRALIAN HULLESS. Also known in some sections as Japanese Rice. Tom Thumb, or Bumble Bee. A heavy yielder of attractive little short ears, nearly as thick as long. Its crowning merit is its popping quality, fine flavor and absence of hull or shell. Pkt., 10c $1 / 2$ lb. 20c; lb., 35c, postpaid.

BLACK BEAUTY. Ripens earlier than any other variety, yet the ears are large in size and the yield is as heavy as that of any of the later sorts. Pops large and is the finest flavored variety of Pop Corn. Although the kernels are black, they show up nice and white when popped. Pkt., 10c; 1/2 lb., 20c; lb., 35̌c, postpaid.

QUEEN'S GOLDEN. Stalks grow six feet high and the ears which are produced in abundance, are larger than other varieties. Kernels rich orange-yellow color, round and smooth; pops perfectly white. Pkt., 10c; 1/2 lb., 20c; lb., 35c, postpaid.

WHITE RICE. The old standard and leading market variety. The improved strain we offer is very prolific, many stalks bearing four large, well developed ears. Pkt., 10c; 1/2 lb., 20c; lb., 35̃c, postpaid.

SPFCIAL OFFER One packet each of Australian Hulless, Black Beauty, Queen's Golden and White Riceall 4 pkts. for $25 \mathrm{c} ; 1 / 2$ lb. of each, 70c, postpaid.

\section{Cucumber}

One ounce of seed for 60 hills; 3 lbs. to the acre.

We take pride in our superior stock of Pedigreed Cucumbers. Better seed cannot be produced anywhere. Market growers and private gardeners will make no mistake by planting our pedigreed seed. Bred for quality, earliness, hardiness, trueness to type and for increase in production. More than that, our seed will cost you no more than just ordinary Cucumber seed.

\section{Burgess' Earlibest}

THE EARLIEST OF ALL SLICING CUCUMBERS AND HOLDS ITS DEEP COLOR BETTER THAN

\section{ANY OTHER SORT}

Burgess' Earlibest is not only the first slicer ready for the market, but the quality is equal or better than that of most of the later sorts and it is a great yielder. It is the most profitable Cucumber for the early market. It is an extra early White Spine, handsome in shape and color, and holds its deep green color better than any other sort. Fruits grow very even in size, usually about seven inches in length, and regular in form. Color dark olive green with lighter lines running from blossom end; smooth, tender and crisp. It is very hardy, robust and free from disease. Ready for market in 55 to 58 days. Pkt. 10c; oz., 20c; 1/1/1b., 55e; lb., \$1.75, postpaid.

\section{Early Fortune}

Only two or three days later than Burgess' Earlibest, and fruits measure about two inches longer. Proclaimed by many growers as the finest type of White Spine Cucumber. The color of the skin is rich dark green, the texture of the pure white flesh is firm and crisp and the seed cavity

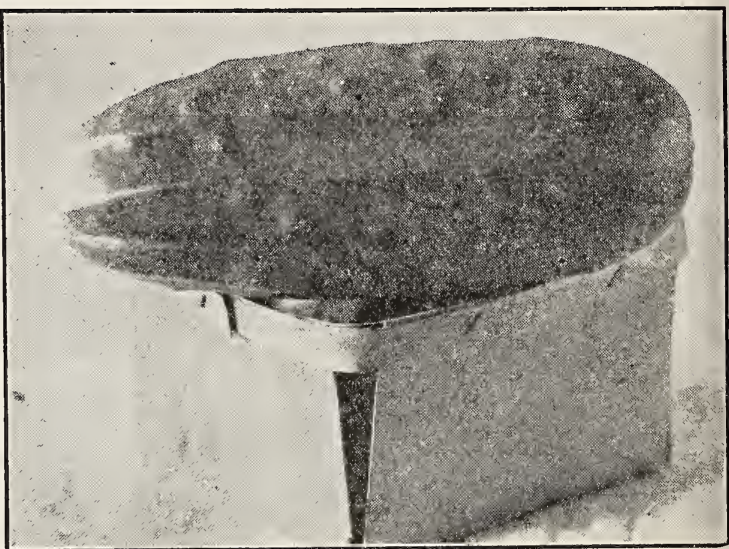

Burgess' Earlibest

\section{Davis' Perfect (Perfected Strain)}

With the exception of the New English Hybrid White Spine, our strain of Davis' Perfect is the most beautiful Cucumber grown. By using our Perfected Strain a crop can be produced outdoors which cannot be distinguished from greenhouse stock. Fruits 8 to 10 inches long; rich, dark green. It has very few seeds, and the few that are in it when in slicing condition are so very small and tender they are unnoticeable. It loads its vines so heavily that it seems impossible for them to mature the fruit. Under glass it is the most productive variety, and for outdoor growing they yield even better than in the greenhouse. For quality it is unsurpassed. Ready for the market in 60 to 65 days. Pkt. $8 \mathrm{c}$; oz., 15c; 1/4 lb., 45c; lb., \$1.50, postpaid.

EVERBEARIXG. Not only extremely prolific, but will continue in bearing throughout the season. Fruits dark green; average from 4 to 5 inches in length. Excellent variety for small pickles. Pkt., 5c; oz., 15c; 1/4 lb., 40c; lb., $\$ 1.25$, postpaid:

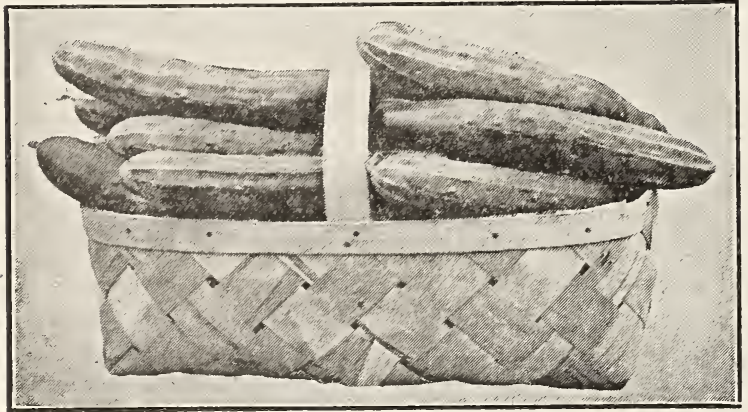

Davis' Perfect (Perfected Strain)
IMPROVED LONG GREEN. 12 to 16 inches in length; excellent quality. Young fruits used for pickling, being a standard sort for that purpose; larger ones excellent for slicing. The most popular variety for making sweet pickles from the ripe fruits. Pkt., 8c; oz., 15c; $1 / 4$ lb. 45c; lb., \$1.50, postpaid.

IMPROVED EARLY WHITE SPINE. A popular standard variety. Largely planted in all parts of the country. Pkt., 5e; oz., 15c; $1 / 4$ lb., 40c; lb., $\$ 1.25$, postpaid.

\section{Market Gardeners and Truckers}

\section{See pages $76,7 \%$ and 78 for Wholesale Prices.}

DIL is easily grown and there is always a big depage 30 . 


\section{English Hybrid White Spine Cucumber The Aristocrat of the Cucumber Family}

ENGLISH HYBRID WHITE SPINE is the result of a cross between English Telegraph and Evergreen White Spine, and combines the valuable characteristics of both. It inherits the fine appearance and shape of the English sort and the hardiness and yielding qualities of the White Spine. Besides its length, which is longer than the White spine varieties, it is much darker in color. The seed cavity is very small, a factor distínctly in its favor as a slicing variety; finest quality, firm and crisp. English Hybrid White Spine is the ideal variety to plant for general crop and will prove to be a real money maker for the grower who caters to the better class of trade, bringing a better price than the shorter and less attractive sorts. Don't fail to put part of your crop in to Early Hybrid White Spine. Pkt., 10c; oz., 25c; $1 / 1 \mathrm{ll}$ lb., 75c; lb., \$2.50, postpaid.

\section{China Long}

This is a remarkable new long green cucumber from China with fruits from 20 inches to 2 feet in length, and only 2 to 3 inches in diameter. The skin is deep green and nearly smooth, the spines being few and small. There is nothing equal to China Long for crispness except possibly some of the hothouse varieties; flesh solid and of the very best quality for slicing. The nearest seedless of any variety we have ever tried. Nearly as early as the shorter varieties; vines strong, vigorous, healthy and productive. A most desirable variety for the home garden, and is. sure to be a popular market sort as soon as it becomes better known. Pkt., 10c; 3 pkts., 25c; oz., 60c; $1 / 1$ lb., \$1.75; lb., \$6.00, postpaid.

\section{MARKET GROWERS ANd others using seed in quantity See Pages 76, 77 and 78}

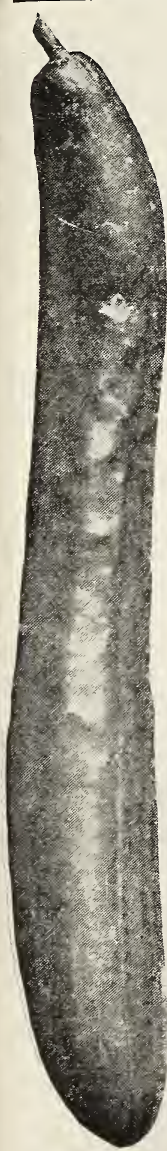

China Long

\section{White Wonder}

Color of White Wonder is beautiful pure whi.te. Remarkably uniform in shape and size, averaging 8 inches long by $2 \frac{1}{2}$ inches thick. Begins to bear early in the season and continues until fall. Flavor is pleasing and flesh firm and crisp. Fine sliced or in salads. Its smooth, clear surface makes the White Wonder an ideal pickle. Aside from the excellent quality of the fruits, White Wonder bears a great quantity of them. A packet of seed will furnish you cucumbers in abundance. Pkt., 10c; oz., 25c; $1 / 4$ lb., 70c; lb., \$2.25, postpaid.

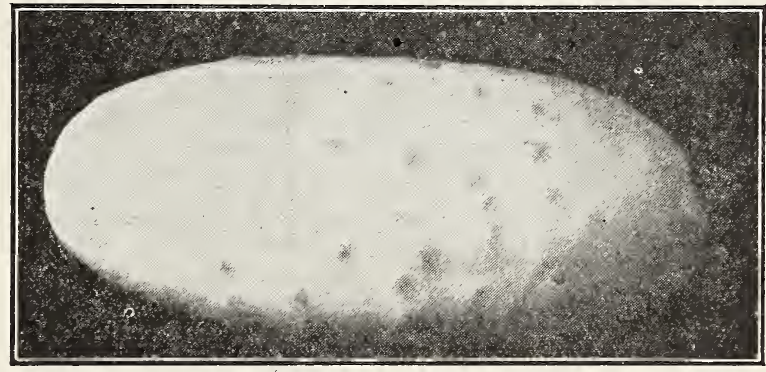

White Wonder

WESTERFIELD'S CHICAGo PICKLING. The variety used almost exclusively by all the leading pickle houses. A very prolific variety. Not extra for slicing, but possesses all the qualities desired by those who raise cucumbers for pickles. Pkt., 5c; oz., 15c; 1/4 lb., 40c; lb., \$1.25, postpaid.

JAPANESE CLIMBING. A good variety to plant to save garden space. The vigorous and healthy vines throw out strong tendrils, enabling them to climb trellis, wire netting or any other suitable support. Owing to the foliage being up off the ground, it resists blight better than other kinds. Fruits long and thick, crisp, tender and of good quality. If kept picked, the vines will bear freely all season. Pkt., 10e; oz., 20e; $1 / 4$ lb., 60e; lb., $\$ 2.00$, postpaid.

LELION. A real Cucumber, similar in size, shape and color to a lemon. It has a flavor that is sweeter and some different from other Cucumbers. They are highly esteemed for pickling, either green or ripe, and for slicing just as the fruits are turning yellow. Will yield four times as many Cucumbers as any other variety. Pkt., 10c; oz., 20c; 1/4 lb., 60c; lb.,\$2.00, postpaid.

WEST INDIA GHERKIN. Small, oval-shaped, prickly fruit; used exclusively for pickling; very prolific. Pkt., 10c; oz., 20c; $1 / 1 / 1$ lb., 60c; lb., \$2.00, post paid.

\section{To Make Money}

with Cucumbers, plant our pedigreed seed. A little fertilizer will also increase the yield, produce an earlier crop and improve their rich green color. See page 78 for fertilizer.

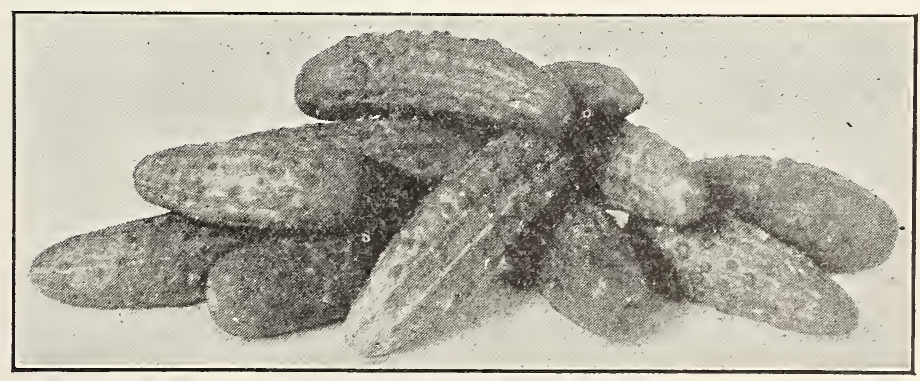

Westerfield's Chicago Pickling 


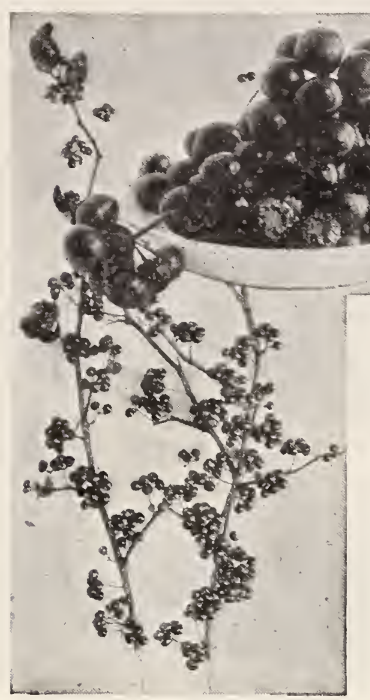

Garden Huckleberry

\section{Corn Salad or Fetticus}

One ounce will plant 40 feet of row.

This is a hardy winter salad, the leaves being served like lettuce during the cool fall and early winter months. It is used also for garnishing meat dishes in the same manner as parsley, and can be cooked like spinach. The seed should be sown thinly in drills during August or September, to supply fresh leaves during the cool fall and winter months. It is quite hardy but, in the Northern States, after cool weather sets in, it should be protected by a thin mulch of straw or leaves. Pkt., 8c; oz., 15c; $1 / 4$ lb., 40c; lb., \$1.25, postpaid.

\section{Cress}

EXTRA CURLED OR PEPPER GRASS. A salad plant that should be grown in every garden. Grows very quickly and seed can be sown as early in the spring as the ground can be worked. For succession make repeated sowings every two weeks from early spring until early fall. Pkt., 5c; oz., 10c; 1/4 lb., 30c; lb., 85c, postpaid.

TRUE WATER CRESS. A hardy plant which will thrive well only when the roots are submerged in water. Can be easily grown in springs or along the edges of shallow running streams. One of the most delicious of all small salad plants. Pkt., 10c; 3 pkts., 25c; oz., 50c; 1/4 lb., \$1.50, postpaid.

UPLAND. Same flavor as Water Cress. Grows on high, dry land. As easily grown as spinach or lettuce. Hardy perennial that can be grown for several years without replanting. Pkt., 8c; oz., 20c; 1/4 lb., 60c; lb., \$2.00, postpaid.

\section{Chives or Schnittlauch}

A hardy perennial onion-like plant. Highly esteemed for use as a salad, and for their small leaves which are produced very early in the spring and are used for giving mild onion flavor to various dishes. Frequent cuttings may be made throughout the season, a new growth of leaves appearing soon after each cutting. Pkt., 10c; 3 pkts., 25c; oz., 60c, postpaid.

\section{Endive or Winter Lettuce}

\section{One ounce will sow 150 feet of row.}

EXTRA CURLED. One of the most refreshing of all autumn and winter salads. May be grown any season of the year, but is more generally used late in the fall. Blanched by tying up the leaves in a conical form for about 10 days before using. Dr. Finck, an authority on foods, recommends it as a food for persons suffering from indigestion. Pkt., 5c; oz., 15c; $1 / 4$ lb., $40 \mathrm{c}$; lb., \$1.25, postpaid.

SELF-BLANCHING. An improved strain of Extra Curled that does not need tying up. Pkt., 10c; oz., 20c; 1/4 lb., $60 \mathrm{c} ; 1 \mathrm{~b} ., \$ 2.00$, postpaid.

BROAD LEAVED BATAVIAN OR ESCAROLLE. Foliage broad and flat-deep green leaves with thick midrib, that is exceedingly palatable when well blanched. Stands dry weather better than any other sort. We believe this variety is unsurpassed for salad when blanched by an experienced gardener, but is more generally used cooked like Kale or Spinach or as flavoring for soups, stews, etc. Pkt., 5c; oz., 15c; 1/4 lb., 45c; lb., \$1.50, postpaid.

\section{Finocchio or Florence Fennel}

A delicious vegetable which should be more largely grown. It is extensively used as a salad in some parts of Europe, and is particularly palatable when served boiled, with a cream dressing. Very distinct from
Sweet Fennel; given the same general cultivation as celery, but requires less blanching. The flavor is somewhat like celery, but sweeter. Pkt., 10c; oz., 25c; $1 / 4 \mathrm{lb}$. 75e, postpaid.

\section{Garden Huckleberry}

Grows from seed the first year. A new fruit that cannot be excelled for Pies and Preserves. It is very prolific, yielding an immense crop of fruit. It is an annual and must be planted each year from seed. Grows and thrives in all climates and on all kinds of soil. The fruit grows

\section{Egg Plant}

One ounce of seed for 1,000 plants.

BLACK BEACTY. The best and the earliest of all large fruited Egg Plants. It is valuable alike to the private planter and to the extensive grower for market. Black Beauty produces fruits fully as large as, and ready for use 10 days to 2 weeks earlier than the New York Improved Spineless. The large fruits are thick, of most attractive form. The skin is a rich, lustrous purplish black. The intensely brilliant coloring is uniform over the whole fruit and does not fade or change to a lighter color at the blossom end. The calyx is bright green, contrasting finely with the dark satin skin of the fruit, and is entirely free from spines or thorns. The fruits set most freely and develop very quickly, so that the entire crop can be gathered before there is any danger of frost. Pkt., 10c; 3 pkts., 25c; oz., 50c; $1 / 4$ lb., $\$ 1.50$; 1b., \$5.00, postpaid.

CHINESE WONDER. Fruits long and slim, often 15 to 25 inches in length. Flesh tender, of excellent quality and very few seeds. A useful vegetable and a very curious and ornamental plant. Pkt., 10c; 3 pkts., 25c, postpaid. larger than the common Huckleberry or Blueberry. If cooked with apples, lemons or anything sour, they make the very finest jelly. You will be delighted and astonished with this easily grown and wonderful novelty. Pkt., 10c; 3 pkts., 25c; 7 pkts., 50c, postpaid.

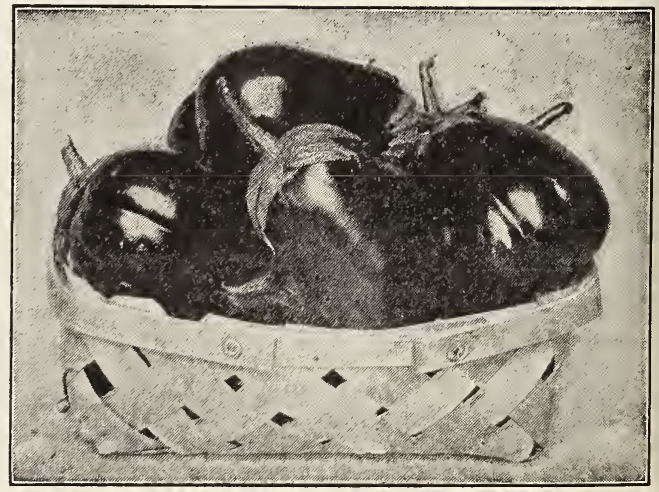

Black Beauty Egg Plant 


\section{Dasheen, the Coming New Vegetable 300 to 900 Bushels Per Acre. The Potato's Only Rival}

We call the Dasheen a new vegetable because it is new in this country, but in fact it has been grown for years in China, and is known in various parts of Europe and Asia.

The Dasheen is grown principally as a root crop, the tubers being used the same as Potatoes. The tubers sometimes reach a weight of more than 6 pounds each. One hill will produce on good, rich soil 6 or 8 pounds or more of tubers, and in rare instances 20 to 26 pounds of Dasheens have been taken from a single hill. Crops of 600 to $900^{\circ}$ bushels per acre have been produced.

The U. S. Department of Agriculture report 1,400 bushels from less than 5 acres in Florida, and on their different experimental grounds have secured yields of 450 bushels to the acre.

Mr. A. I. Root, editor of "Gleanings in Bee Culture," has this to say regarding the Dasheen: "Although the Dasheen is still mostly confined to the South, yet I might say that we are now growing our third crop here in Northern Ohio, and I feel more and more satisfied that it can be grown profitably all over our Northern states; and will ultimately prove to be one of our most nourishing and toothsome vegetables."

The "Country Gentleman" published the following regarding it: "Not only does the Dasheen promise well as a market crop once the public generally has recognized its merits, but in the meantime it is capable of furnishing food for home consumption. Its food value is higher than the potato, and about fifty per cent more protein and fifty per cent more starch. The flavor of the Dasheen is decidedly richer and more tempting than that of the potato."

Land that is too wet for ordinary crops can be used to advantage in growing Dasheens. They can be grown on lands that are subject to short overflows that would ruin most other crops, thus making much land available for food crops that is now considered worthless. They may also be successfully grown in hot, dry regions as has been demonstrated by tests in Arizona and in the desert regions of Southern California.

The Dasleen can be used in almost any way that Irish Potatoes or Sweet Potatoes can be used. They are excellent when baked, boiled, fried, creamed, stuffed, meat filled or scalloped, and for Saratoga Dasheen Chips and Fritters they are delicious.

Dasheen crisps, made from raw Dasheen with a fluted vegetable slicer and fried in deep fat, are declared by some epicures to be the most delicious of all Dasheen dishes. The delicate, nutty flavor of the Dasheen is accentuated by this method of preparation.

As a filling for fowl and other meats the Dasheen can hardly be surpassed. Served au gratin, that is, cooked with grated cheese, it is equal to any similar dish. It makes a delicious salad and may be French fried or German fried like potatoes.

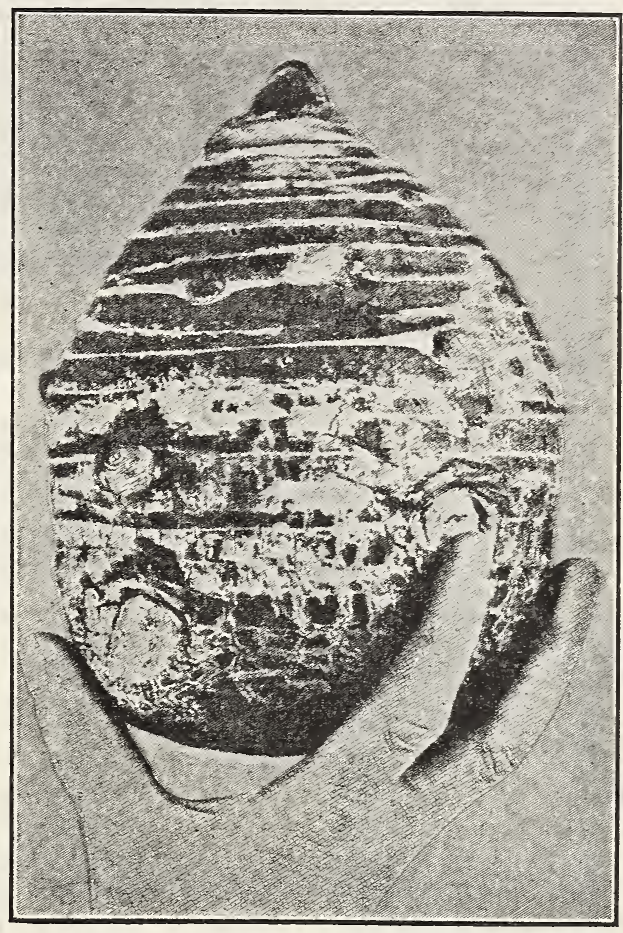

A 5-Lb. Dasheen Tuber

The young leaves of the Dasheen make excellent greens, used

The stems, when grown under a box or barrel, so as to be bleached, are equal to Asparagus. The Department of Agriculture says: "The shoots are very tender and have a delicate flavor, suggestive of mushrooms. There are probably few plants so well suited for forcing purposes as the Dasheen." Experiments carried on by the Battle Creek Sanitarium, at Battle Creek, Mich., indicate that 5 to 8 crops of these shoots can be harvested.

DASHEENS AS STOCK FFED. The United States Department of Agriculture, in their year book, have the following to say regarding the Dasheen as a stock food: "Although extensive feeding experiments with the Dasheen have not yet been made, as a stock feed it is probably equal in value to the potato, sweet potato, or eassava. They seem, in the raw state, to be more palatable to stock than potatoes and, while doubtless less palatable than sweet potatoes, with a relish after getting the taste, and pigs 8 months old have been fattened for the market in a month by turning with a relish after getting the taste, and pigs
them in the autumn into a patch of Dasheens."

Planting should be done as early in the spring as conditions of soil and climate will permit. For field culture the tubers are planted singly and entire, not more than 2 to 3 inches deep in hills 3 feet apart, the distance between rows being 4 feet. This will permit horse cultivation. In cultivating during the summer the soil should be gradually drawn to the plants and the ground kept free from weeds, but require little cultivation after large enough to shade the ground.

In growing Dasheens there seems to be no disease or insect enemy to contend with, as there is in growing potatoes. No dreaded potato bugs to be poisoned; no rot, scabs, blight, mildew or other trouble

The leaves are large and very ornamental, resembling closely the Caladium Esculentum, or Elephant's Ear. "Every town and city garden should plant a few of these interesting plants to see what the people in other parts of the world raise for food.

The Dasheen is sure to be a "gold mine" for growers in all parts of the country where the season is not too short. While we would not recommend it as a big money maker for the North, we surely consider it worthy of a place in every garden. If you haven't room to give them a trial in your garden, you can at least plant a few for ornamental purposes and at the same time find out what they are like. You will find them one of the finest vegetables and most showy ornamental foliage plants. As our stock of tubers is limited, we recommend that you send your order early.

Choice seed tubers, 3 for $40 \mathrm{e} ; 6$ for $75 \mathrm{c} ; 12$ for $\$ 1.25 ; 25$ for $\$ 2.00$; 50 for $\$ 3.75 ; 100$ for $\$ 7.00$; delivered to you prepaid. Pamphlet giving cultural directions and recipes for preparing and cooking the Dasheen, free with each order.

\section{A Pleased Customer from Canada}

Under date of Sept. 21, 1926, Alice Thompson, Paisley, Ont., Canada, wrote us as follows:

"We got some seed and plants from you this spring and we are very much pleased with them. I got 2 or 3 mixed packages of your Nasturtium seed. They were lovely. They are flowering away yet. There was such a variety of colors. We had a flower show here the 2nd of September. I got first prize for my collection of Nasturtiums. We also liked the vegetable seed. The cucumbers, carrots and beets are lovely. I got the 3 roots of Marshmallow or Hibiscus. They are all growing fine."

\section{CHINESE VEGETABLES}

LUFFA ACUTANGULA (Edible Disheloth Gourd). Known to Chinese as Sing-kwa. The fruit is eaten when young, being cooked like squash or served in soups and stews. The young fruit is sometimes sliced and dried. Culture is the same as for cuoumbers and melons. Pkt., 10c; 3 pkts., 25c, postpaid.

MOMORDICA CHARANTLA (Balsam Pear). Known to Chinese as La-kwa. Grown for the edible pulpy arils surrounding the seed; also for the edible fruit itself which is prepared, usually by boiling, before it is ripe. Vine grows 10 feet or more. Pkt., 10c; 3 pkts., 25c, postpaid. 


\section{Burgess' Choice Lettuce}

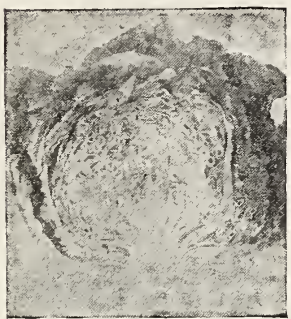

Big Boston Lettuce
One ounce will sow 125 feet of row or produce about 3,000 plants. 4 pounds to the acre.

BEFFSTEAK. One of the best varieties for the home orden. Does not form tightly folded heads, but makes a compact bunch of leaves. The large, crimped leaves are highly colored brownish-red; crisp, sweet and exceedingly tender; very early, and stands a long time without going to seed. Pkt., 10c; oz., 25c; 1/4 lb., 75c; lb., \$2.50, postpaid.

BIG BosToN. The best head lettuee for forcing under glass, and one of the best for outdoor planting. Produces large, solid heads, often 10 to 12 inches across. Excellent quality; sure to head. Pkt., 5c; oz., 20c; $1 / 4$ lb., 60c; lb., \$2.00, postpaid.
BLACK SEEDED SIMPSON. The most popular BLACK SEEDED SIMPSON. The most popular
curled or loose-leaved sort for early outdoor plantIng. Plst., 5c; oz., 15c; $1 / 4$ lb., 45c; lb., \$1.50, postpaid.

\section{Burgess' Celery Lettuce}

Burgess' Improved Cos or Celery Lettuce is an entirely distinct type of lettuce, and is rapidly gaining favor. The plants are of erect growth, forming a slightly oblong bunch of large, crisp leaves. The outer leaves should be gathered iogether at the top and loosely tied with a piece of soft string for several days before wanted for use. This blanches the inner leaves to snowy whiteness and brittle crispness. BURGESS IMPROVED is the best variety. always sweet and tender and of the best quality, even when grown during the hot summer months. Pkt., 10c; oz., 25c; $1 / 41$ lb., 50c; lb., \$2.25, postpaid.

CALTFORNIA CRFAM BUTTER. Large solid heads; rich and buttery. Grown extensively in the South. Pkt., 5c; oz., 15c; $1 / 1 / 1 b ., 45 c ; 1 b ., \$ 1.50$, postpaid.

GRAND RAPIDS FORCING. The best loose-leaved sort for forcing under glass and an excellent variety for outdoor planting. Pkt., 5c; oz., 20c; $1 / 4 \mathrm{db}$. 60c; lb., \$2.00, postpaid.

IMPROVED HANSON. Will st a $\mathrm{d}$ more hot weather than any other sort, excepting "Celery" Lettuce. Immense solic heads. Pkt., 5c; oz., 20c; $1 / 4$ lb., 50c; lb., \$1.65, postpaid.

MAY KING. The earliest head lettuce grown. Excellent quality. Pkt., 5s oz. 20c; $1 / 1$ lb., 60c; lb. $\$ 2.00$, postpaid.

\section{SPECIAL PRICES}

By making up an order for a total of ten pounds or more of seed, you can buy at wholesale prices. For full particulars see page $\mathbf{7 6}$.

\section{Los Angeles Lettuce}

The greatest head lettuce ever introduced, and furnishes fine crisp lettuce during the hot summer months. The largest variety grown, often producing heads weighing more than 2 pounds each, nearly as solid as a cabbage, and inside leaves blanched to beautiful creamy-white. Stands shipping as well as cabbage and remains in condition longer than other sorts. The most crisp and tender head lettuce grown. Pkt., 10c; oz., 25c; $1 / 4$ lb., 75c; lb., \$2.50, postpaid.

\section{Chicken or Rabbit Lettuce}

The best green feed for chickens or rabbits. In this new variety you will find a feed that yields as much or more than other green feeds. It is economical to grow, for when cut it resumes its growth rapidly and can be cut again and again; or the leaves can be pulled off each stem like the Jersey Kale. The yield is extremely heavy. Chicken or Rabbit Lettuce is too coarse for a table variety. Grows 3 to 4 feet high and just loaded with large leaves, Pkt., 10c; 3 pkts., 25c; oz., 50c; 1/4 lb., \$1.50; lb., \$5.00, postpaid.

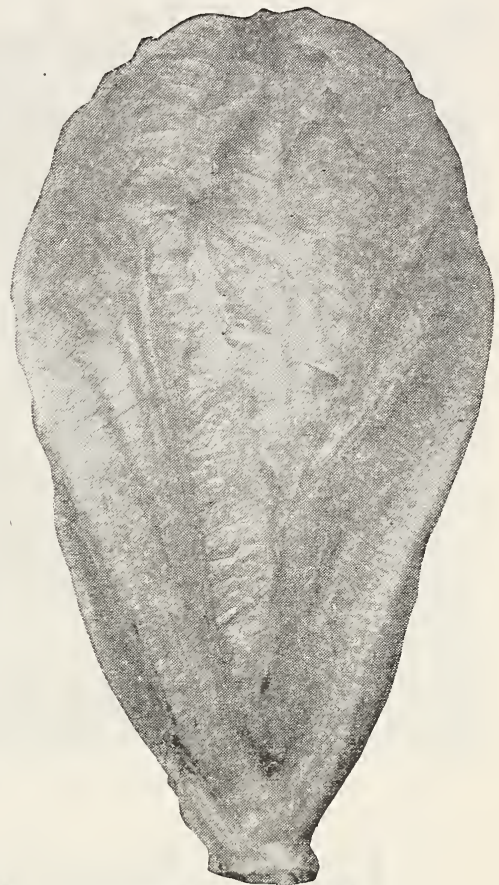

Burgess' Celery Lettuce

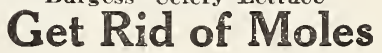

It is claimed that moles will not stay where Castor Oil Beans are growing. While we can not vouch for the accuracy of this statement, we have tried it out one season, and with very encouraging results. We grew Castor Beans throughout one of our trial gardens, planting them about 15 feet apart each way This was a garden that is usually badly infested with moles. The result was that not a sign of a mole was seen in the garden during the entire season. This is only one season's test, so there miglit possibly have been some other reason, but it is worth trying anyway. The Castor Bean seed we offer is a mixture of the most ornamental varieties, which would be very attractive in either flower or vegetable garden. Pkt., 10e; oz., 20c; $1 / 4$ lb., 60c; lb., $\$ 2.00$, postpaid.

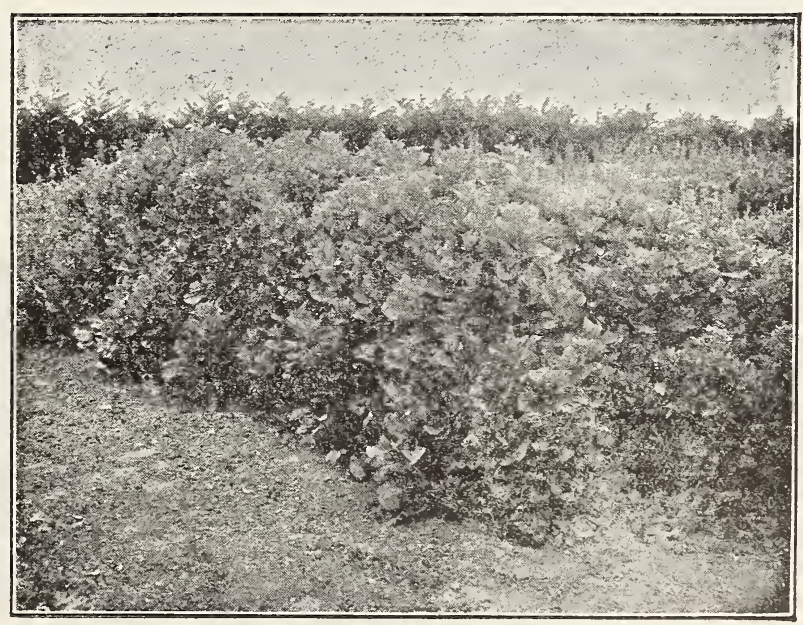

Chicken or Rabbit Lettuce 


\section{Burgess' Michigan Grown Muskmelon Seed \\ One ounce of seed for 50 hills; 3 pounds per acre.}

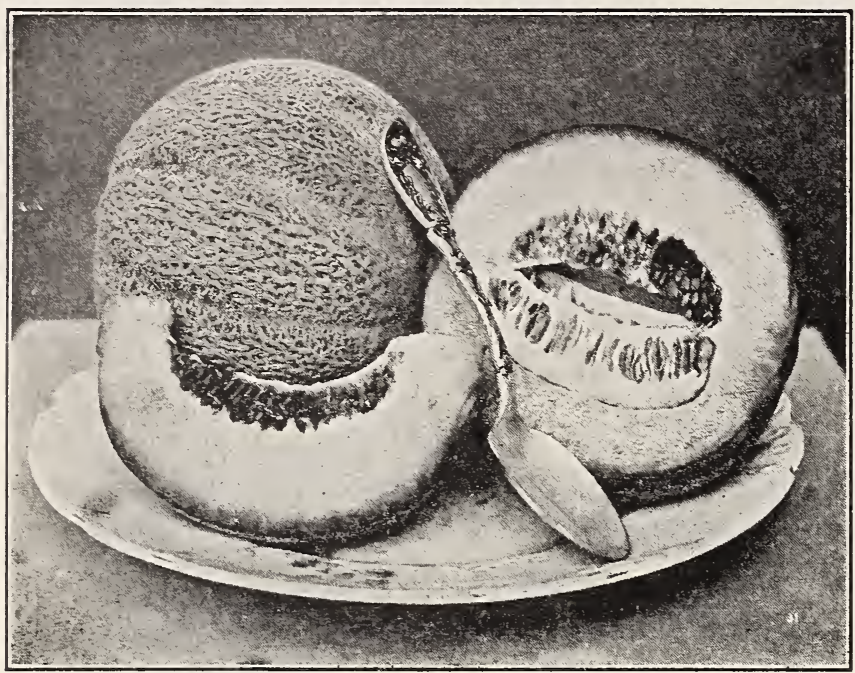

Hearts of Gold

There are many localities other than Mnchgan in which excellent Muskmelon seed is produced but none that combines the excellent quality with the extreme earliness that our Michigan grown pedigreed seed does. The assurance of a big crop of melons of best quality, and ready for market a few days ahead of melons grown from seed produced elsewhere, is of the very greatest importance to the market grower. You can order your Muskmelon seed from us with the assurance that better seed can not be secured anywhere.

\section{Hearts of Gold}

The Hearts of Gold Muskmelon was first offered planters but a few years ago, and owing to its superior quality has rapidly taken first place in all localities where it has been introduced. This variety has been grown extensively in Michigan for the past five years and now stands at the top of the list as a shipper. It is just the right size so it may be served in halves. Average weight $1 \frac{1 / 2}{2}$ to $1 \frac{1}{4}$ lbs. Flesh deep orange, extremely thick, fine grained, of the very best quality and very sweet and melting. You will make no mistake in planting this variety. It is a money maker for market gardeners and few, if any, are its equal for the home garden. It is a marvel of productiveness. Ripe fruits in 75 days. Pkt., 10c; oz., 20c; $1 / 4$ lb., 55c; lb., \$1.75, postpaid.

\section{Lake Champlain the "Money-Maker" Melon}

\section{The Earliest Muskmelon of Good Quality}

Our Michigan grown seed of this variety produces ripe fruits in 57 to 60 days from date the seed is planted in the field, bringing your crop ahead of competitors and netting you the top market price. The Cornell University Experiment Station reports this melon to be much earlier than any other in their very extensive trials. It is not only the earliest Muskmelon of good quality, but it is so good that Professor Tompson of the Massachusetts Agricultural College reports it as the best in quality he has ever eaten. The flesh is deep, very sweet and melting, of golden yellow color; a small round melon; nicely netted. The plant is very vigorous and healtby, setting and ripening melons even under adverse conditions. It is not a long distance shipping melon, but will give you the earliest quality melon for the local market, and net you more profit than any other Muskmelon grown. From a half acre patch, 986 halfbushel baskets were sold at $\$ 1.00$ per basket, making a gross profit of nearly $\$ 2,000.00$ per acre. Pkt., 10c; oz., 25c; $1 / 4$ lb., 75c; lb., \$2.50, postpaid.

\section{Bender's Surprise}

\section{The Best Large Size Muskmelon}

Exquisitely fine flavor, large size and medium earliness combine to make this new melon a great favorite. Melons average quite large, many weighing 10 pounds or more; oval in shape; light green with coarse netting, and turn a

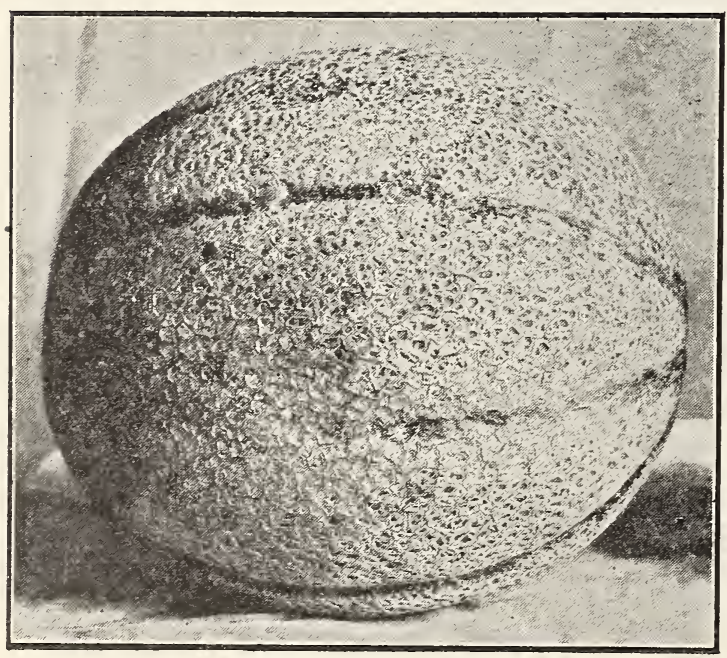

Bender's Sarprise golden tint as they mature. Flesh deep orange, very thick and deliciously sweet. Will keep in good condition a week after picking, and actually improve in flavor during that time. The flesh is so firm and thick that the melons remain firm and in good condition much longer than any other large melon of this class. For market and shipping this is an important consideration. We do not know of any other large Muskmelon quite equal to the Bender for either the market or the home garden. Pkt., 10c; oz., 20c; 1/4 lb., 55c; lb., \$1.75, postpaid.

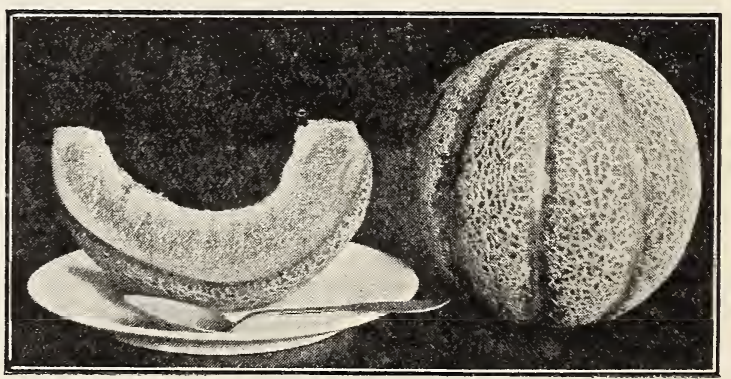




\section{MUSKMELON-Continued}

EXTRA EARLY HACKENSACK. The best early green fleshed muskmelon and one of the hardiest and most prolific. Ripe fruits In 65 days-fully 10 days ahead of the well known old Hackensack. Fruits round, flattened at the ends, irregularly ribbed and heavily netted. Flesh green, thick, of excellent quality and flavor. Melong are of good size, weighing from 5 to 10 pounds each. Pkt., 5c; oz., $15 \mathrm{c} ; 1 / 2$ lb., 40c; $1 \mathrm{~b} ., \$ 1.25$, postpaid.

OHIO SUGAR. Nearly all who have tried it pronounce it the best of all green fleshed melons. It is one of the sweetest and most luscious cantaloupes now on the market. Of desirable size, round, inclined to oval in shape, distinctly ribbed and thickly netted; color of skin gray-green. Because of its firm flesh and solidity, it is a splendid shipper. Seed cavity small. The flesh is an attractive green of fine texture, sugary, juicy and tender. Pkt., 10c; oz., $20 \mathrm{c} ; 1 / 4$ lb., 60c; lb., $\$ 2.00$, postpaid.

OSAGE, or MULLER'S CREAM. The most popular main crop variety. Fruits medium in size, salmon flesh, thick, fine grained and highly flavored. A good shipper, and always in demand. Our Michigan seed produces ripe fruits in 75 days. Pkt., 5c; oz., 15c; $1 / 4$ lb., 45c; lb., \$1.40, postpaid.

ROCKY FORD. The most famous Muskmelon. Melons nearly round and uniform in shape and size. Flesh light green, very deep, ripening clear to the rind. Delicious, delicate spicy flavor. Pkt., 5c; oz., 15c; $1 / 4$ lb., $40 \mathrm{c}$; lb., $\$ 1.25$, postpaid.

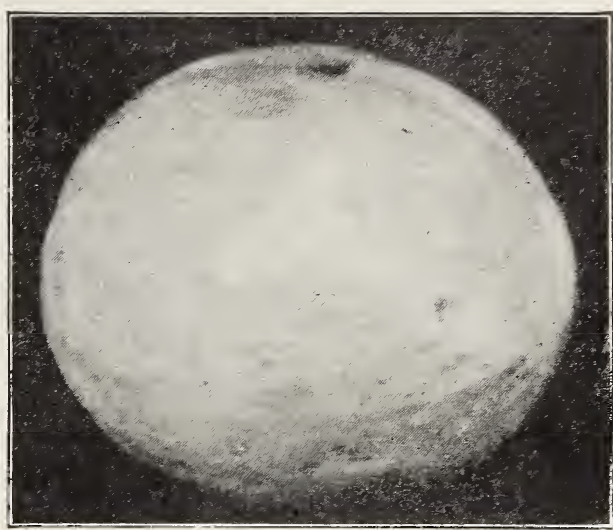

Honey Dew Melon

\section{"Honey Dew" the Famous Melon}

This new fruit is a cross between the Rocky Ford Cantaloupe and a South Sea Island Casaba and has retained all the best qualities of both and is better than either. The melon is nearly white, turning to lemon-yellow when ripening, and the average size is a little larger than that of a coconut. The flesh is light green, the juiciest and sweetest Muskmelon and luscious in flavor. The rind is hard. It is good as soon as picked off the vine and will keep good for months if kept in a cool, dry place. It is therefore a good shipper and a most splendid fruit to grow for the market. One prominent shipper is urging melon growers to plant largely of the Honey Dew, saying it would put the Rocky Ford Cantaloupe out of business.

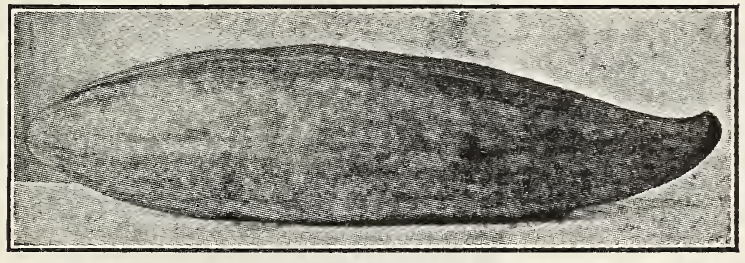

Banana Muskmelon
In the city markets the Honey Dew sells at higher prices than any other melon, and there is every reason to believe that as soon as the productiveness, unsurpassed quality and shipping characteristics of Honey Dew becomes generally known it will become a standard variety and every gardener will grow it. As a local melon, it advertises itself. The first one eaten creates a desire for more. Plant it in your home garden. It will afford you more pleasure than any other vegetable you have. Ripe fruits in 90 to 120 days, depending upon the season. Full grown fruits that do not ripen on the vines before the fall frosts, can be picked and will ripen in storage. Pkt., 10c; oz., 20c; 1/4 lb., 55c; lb., \$1.75, postpaid.

\section{Banana Muskmelon}

This melon surpasses all others in its delicious fragrance. The flesh (the melon being nearly solid) is of a rich salmon. The quality is excellent when the melon is thoroughly ripe. It grows from 18 to 36 inches in length. and is very prolific. It looks almost like an overgrown banana and smells like one. Has a flavor all its own. Very sweet and delicious. Don't fail to try it. Pkt., 10c oz., 20c; $1 / 4 \mathrm{lb}$., 55c; lb., $\$ 1.75$, postpaid.

MARKET GARDENERS AND TRUCKERS Don't order until you have read what we buy seed in large quantities you can save money by ordering at have to say at the top of page 76 . If you

\section{Michigan Grown Watermelon Seed}

Plant Michigan Grown Watermelon Seed for Early Maturity. Be First on the Market. Northern seed is adapted to all climates and is the best for both the Northern and the Southern planter, because it has been matured in a short season and will grow hardier plants and earlier melons than Southern seed. We sell thousands of pounds of Watermelon seed to Southern planters who grow early melons to ship North. The fact they continue planting our seed each year, and pay more for it than they would have to pay for seed grown in their own locality, should be proof that our seed is worth more. A few days earlier maturity means considerable to both the Northern and the Southern market grower. one ounce of seed for 25 hills; 4 pounds per acre.

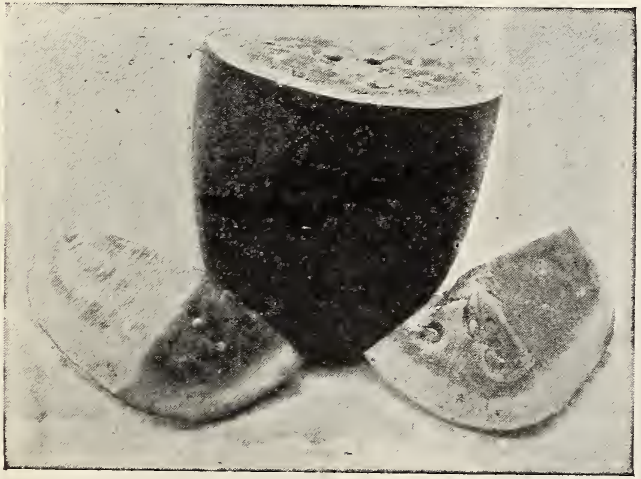

\section{Tom Watson}

Although of recent introduction, Tom Watson is the most popular of all Watermelons, occupying a very prominent place in all markets, and is everywhere called for The flesh is superb in quality and of the brightest red color. The handsome, dark green rind is thin, but hard and tough, so is unsurpassed as a market and shipping sort. The melons are usually 20 to 24 inches in length and 10 to 12 inches through, averaging on good soil over 30 pounds each, and single specimens often weighing 50 to 60 pounds. A good yielder and a great money maker on all markets. Matures in 85 days. Our Michigan grown seed cannot be excelled. Pkt., 8c; oz., 12c; 1/4 lb., 35c; lb., \$1.00, postpaid. 


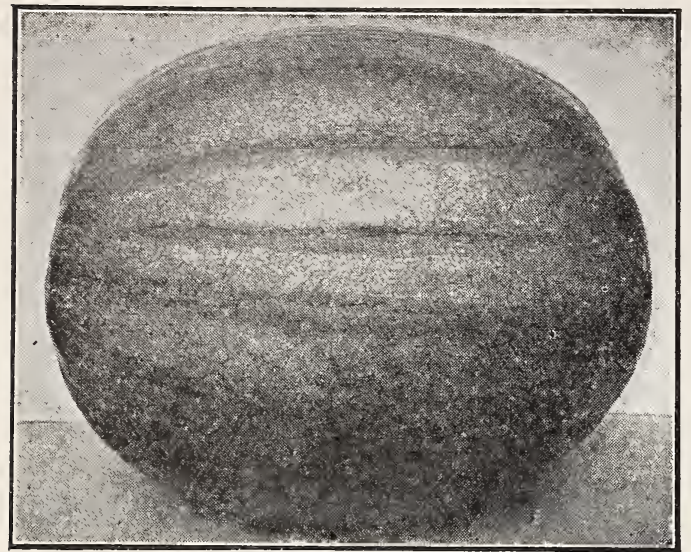

Pride of Yukon

\section{Pride of Yukon Ripe Watermelons in 65 Days}

Not only is the Pride of Yukon the earliest Watermelon known, but it is unsurpassed for sweetness and quality; entirely free from stringiness, and fairly melts in your mouth.. Fruits are of attractive appearance; medium in size, seldom. exceed 18 to 20 pounds in weight, averaging 10 to 15 pounds; flesh bright scarlet. Hardy, vigorous and remarkably productive. The best for extra early planting, especially adapted. to Northern localities where the season is short, but does well in all sections of the country and has created a sensation. wherever grown. While it is not an extra good shipper, it is a wonderful melon for the home garden and a gold mine for the market gardener. Pkt., 10c; oz., 15c; $1 / 1 / 4$ lb., 45e; lb., $\$ 1.50$, postpaid.

COLE'S EARLY. The leading extra early Watermelon in nearly all parts of the country. Only 5 days later than Pride of Yukon; excellent quality; small in size, but what they lack in size they make up in number. Pkt., 5c; oz., 12c; 1/4 lb., 35e; b., \$1.00, postpaid.

HARRIS EARLY. The best extra early shipping melon. Larger and tougher rind than Cole's, and only 4 or 5 days later. Pkt., 5c; oz., 12c; $1 / 1 / 1$ lb., 35c; lb., \$1.00, postpaid.

PEERLESS. The earliest large long Watermelon. Our strain of this wonderful melon ripens the same time as Harris' Early, or about 10 days later than Pride of Yukon. For the Central and Northern States, we consider this the best general cropper for the home market; has too thin a rind for shipping unless packed in straw. Fruits larger than Halbert Honey or Kleckley's Sweet and 10 days earlier; rind light green, mottled and veined; flesh bright scarlet, solid to the center, tender, sweet, melting and delicious. Few, if any, surpass it for quality or productiveness. Pkt., 8c; oz., 15e; $1 / 1 /$ lb., 40c; lb., \$1.25, postpaid.

KLECKLEY'S SWEET or MONTE CRISTO. One of the most if not the most popular melon for the home garden and for nearby markets, because of its superb flavor and surpassing crispness. No melon sweeter than Kleckley's Sweet. Average length 18 to 20 inches; color very dark green; season medium early. Pkt., 5e; oz., 12c; $1 / 4$ lb., 35e; lb., \$1.00, postpaid.

HALBERT HONEY. Very similar to Kleckley's but preferred by many on account of it being more perfect in shape. Same length, but not so tapering toward the stem end. Pkt., 5e; oz., 12c; 1/4 lb., 35c; lb., \$1.00, postpaid.

IRISH GRAY. A melon of uniformly large size, closely resembling Kleckley's Sweet, with the exception of the tough rind which is gray in color. Ripens earlier than Tom Watson and will keep in good condition for a long time. A wonderful variety for the home garden and for shipping; unusually sweet and of best quality. Will produce more good marketable melons than any other variety we know of. Pkt., 8c; oz., 15c; $1 / 4$ lb., 40c; lb., \$1.25, postpaid.

ALABAMA SWEET. A popular variety in the South. Pkt., 5c; oz., 12c; $1 / 1 /$ lb., 35e; lb., \$1.00, postpaid.

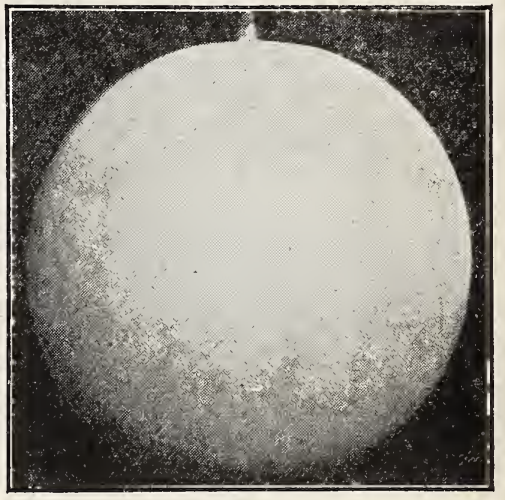

Winter

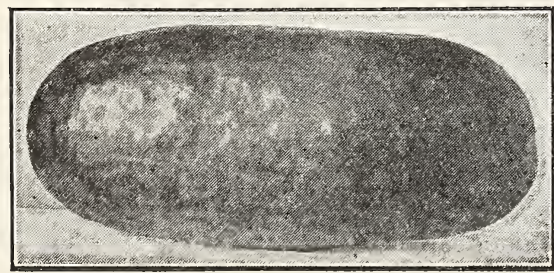

SWEET HEART. Large round melon; ripe in 90 days; good shipper. Pkt., 5e; oz., 12e; 1/4 lb., 35e; lb., \$1.00, postpaid.

GOLDEN HONEY. Excellent yellow-fleshed variety. Sweet as honey. Pkt., 10c; oz., 15c; $1 / 4$ lb., 45c; lb., \$1.50, postpaid.

COCONUT or CLIMBING. The vine may be allowed to trail on the ground or may be trained and tied to trellis. Melons about the size of a large coconut and of the highest quality. Fruit ripens for a long period, unlike other sorts which ripen their fruit mostly at one time. An ideal melon for the small garden. Only a limited amount of seed. so are offering it in packets only. Pkt., 10e; 3 pkts., 25c, postpaid.

CITRON. Flesh white and solid. Used exclusively for making pre:serves. Pkt., 8c; oz., 15c; 1/4 lb., \$1.25, postpaid.
Peerless

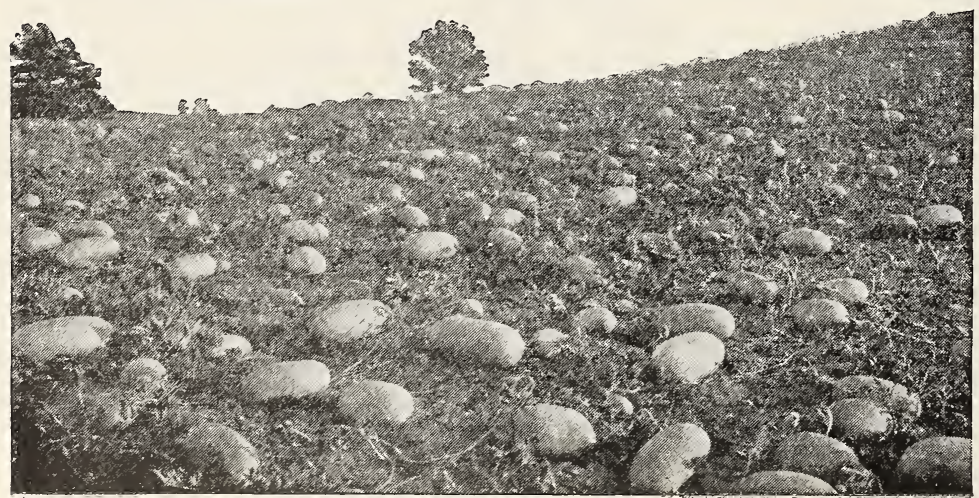

\section{Winter}

A home grown melon for your Thanksgiving dinner. It is not a citron or a freak, but a very prolific: long-keeping true Watermelon. Flesh. red, extremely firm, very brittle and deliciously sweet. Fruits taken from the field before killing frost and stored in a cool place will keep long. into the late fall and early winter and retain their delicious sweetness and flavor. Plit., 10c; oz., 20c; 1/4 lb., $\$ 1.75$, postpaid. 


\section{Mammoth Prize Watermelon}

Mammoth Prize or Improved Triumph is the largest Watermelon grown. Many grow to from 100 to $150 \mathrm{lbs}$. On one vine, five melons were grown that weighed $152,151,148 \%, 1491 / 4$, and 147 lbs., the five weighing a total of $748 \mathrm{lbs}$. The seed we offer is extra select, and should produce fine, sweet, juicy melons of excellent quality and enormous size. Pkt., 10c; oz., 20c; 1/4 lb., 55c; lb., \$1.75, postpaid.

\section{New Guinea Butter Vine}

\section{One of the Most Delicious of All Vegetables}

We are offering planters another vegetable of real worth and merit. Nearly every one who has tried it speaks of it very highly. The New Guinea Butter Vine is a member of the edible gourd family and in growth is similar to the squash, and can be grown in the same manner or can be trellised up. It is wonderfully prolific, considerably more productive than squash and much easier to grow. The vines are always free from disease and insect pests, and really stand more neglect and abuse than any other vegetable vine we know of.

The fruits of the New Guinea Butter Vine grow to an enormous size, often 3 to 5 feet in length, but should be eaten when small, while the fuzzy growth is yet on. They can be cooked like Squash, fried like Egg Plant, pickled like Cucumbers, or cut up in small pieces and cooked with cream. When cooked with cream or fried it is most delicious, and if you would like to try something new this season, you will find that this vegetable is a most desirable addition to your garden.

The New Guinea Butter Vine is so productive that three plants will supply any ordinary family. If trellised up, the vines take up so little space, no garden is so small but that room can be found somewhere for at least two or three plants. One of our customers who tried it writes us that he cut 75 fruits from one vine, and that each fruit was from $2 \frac{1 / 2}{\text { to }} 3$ feet long. Pkt., 10c; 3 pkts., 25c; 7 pkts., 50c; 15 pkts., \$1.00, postpaid.

Wholesale Prices Planters who purchase seed in bulk and 10 Iibs. of all kinds combined-are entitled to wholesale prices, as show $n$ on pages 76,77 and 78 . Read instructions at the beginning of page 76 before ordering. You can save some money and get the best seeds obtainable by getting your entire supply from us.

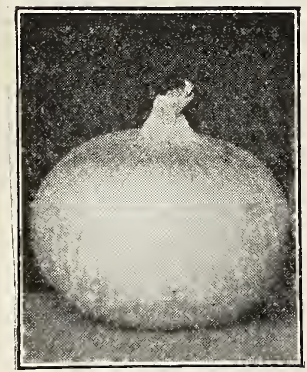

Whito Portugal

\section{Burgess' Choice Onion Seed}

Onions usually net the grower more money per acre than any other vegetable crop. If you are going to raise a crop that requires the labor and capital that Onions do, don't waste your time cultivating a field of culls. The difference in price, if any, between a good strain of carefully grown seed and a poor strain, carelessly grown, is so small that you can only afford to plant the very best. There are many inferior strains of Onion seed being offered to the public at low prices which will produce Onions of all sorts and sizes instead of the uniform, marketable crop obtained by planting a carefully selected strain of seed. Each year a large and steadily increasing number of market gardeners buy our Onion seed because they realize that none is superior.

One ounce of seed for 150 feet of row; 4 to 6 lbs. per acre.

\section{Australian Brown}

As the Australian Brown becomes better known its popularity increases. It is now much in demand in both the Eastern and Western markets, and we have no hesitancy in saying that we believe in a comparatively short time it shall be King of all market Onions. It is of semi-globe shape, brownish-yellow in color, solid, white flesh and very mild and sweet. The Onions grow to a fair size and ripen evenly and without a neck. They begin to form a bulb very quickly and reach maturity in a remarkably short time. It is a good yielder and a sure cropper and is noted for its long keeping qualities, having been kept in fine condition for a year after harvest. We consider it by far the best Onion for sections where the season is

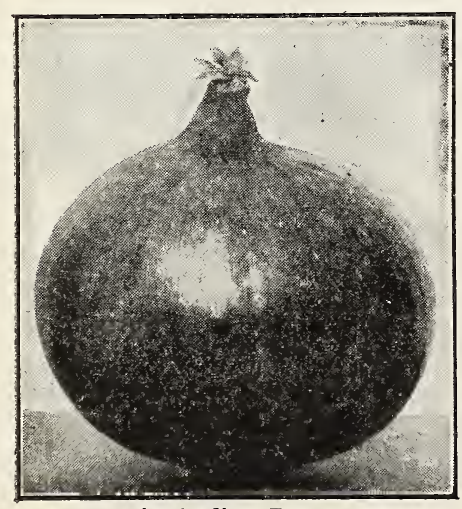

Australian Brown short, and a most dependable variety for all climates. It is one of the best of all Onions for bottom sets, fine for little green Onions from seed, and for ripe Onions for cooking there is nothing better. Should be grown by every market grower and in every home garden. Pkt., 10c; oz., 25c; 1/1 lb., 75c; lb., \$2.50, postpaid.

\section{Early White Welsh}

White Welsh is the best kind for green onions. It forms no bulbs, and is the first variety to be ready in the spring. Market gardeners find it extremely profitable, as it makes a most attractive bunch and sells at good prices before. onions grown from sets are ready for the market. It is a perennial, perfectly hardy, and when once set out will remain in the ground year after year. It does not produce top sets, but is propagated from seed or divisions. It is very mild, of excellent quality, and no garden is complete without a row of these onions. Pkt., 10c; oz., 30c; $1 / 4 \mathrm{lb}$., 90c; lb., $\$ 3.00$, postpaid.

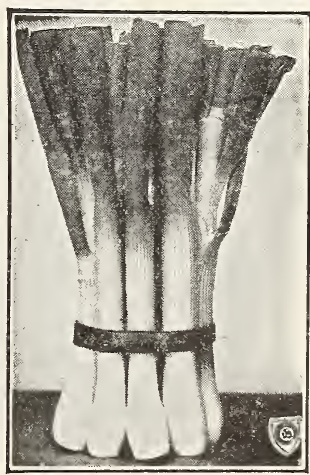

Early White Welsh 


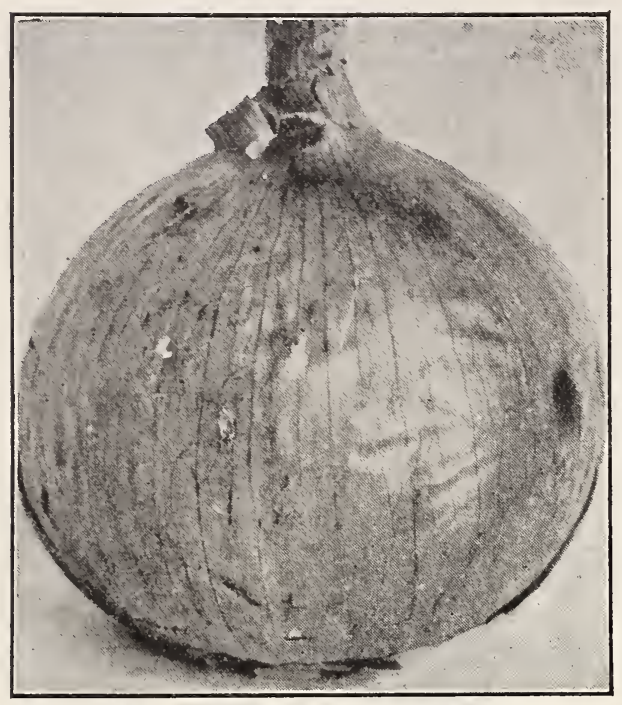

Mammoth Spanish or Prizetaker

\section{Mammoth Spanish Onion}

Mammoth Spanish, or Prizetaker, is the big yellow variety you see for sale in the fruit stores. It is an excellent keeper, a handsome Onion of perfect globe shape and enormous in size, many single Onions having been raised to weigh more than five pounds. The flavor is very pleasant, mild and sweet. Plant the seed early and you can easily grow these large, sweet, mild, juicy Onions. We have an extra select strain of this variety. Be sure to get the genuine. Pkt., 10c; oz., 30c; 1/4 lb., 90c; 1b., \$3.00, postpaid.

\section{Ebenezer or Japanese}

This is the mildest flavored Onion grown. The flesh is white, firm and of a very delicate flavor. The Onions are quite similar to Yellow Globe Danvers in shape but much larger in size, yellow skinned and have very small tops and mature early. Many people who know this Onion will have no other kind for their own table. In the localities where it has been grown, the Onions of this variety command much higher prices than other kinds. Those who want a nice mild Onion, either for large Onions or bottom sets, would do well to try the Ebenezer. You should grow your own sets if you want to be sure of genuine Ebenezer. Sets are grown the same as large Onions, except that the seed is sown thickly-one pound of seed to each 100 feet of drill. These sets, if planted early in the spring, will produce ripe Onions in July, at which time they will bring a high price. Sets of this variety rarely produce seed stalks as other kinds do. The Ebenezer is such a good keeper that even those ripening in July will keep sound and hard through the fall and all winter. Don't fail to plant some Ebenezer Onion seed this season, sowing some for large onions and some for sets. Pkt., 10c; oz., 40c; $1 / 4$ lb., \$1.25; lb., \$4.00, post paid.

EXTRA EARLY RED FLAT. The earliest red Onion. Will form bulbs in cold mucky soils where the seasons are so short other varieties frequently fail to ripen. Pkt., 8c; oz., 25c; 1/4 lb., 70c; lb., \$2.25, postpaid.

EXTRA EARLY BARLETTA. Very small white pickling Onion. Pkt., 10c; oz., 40c; 1/4 lb., \$1.25; lb., \$4.00, postpaid.

LARGE RED WETHERSFIELD. The standard main-crop flat red variety. Pkt., 8c; oz., 30c; 1/4 lb., 90c; lb., \$3.00, postpaid.

MAMMOTH SILVER KING. The largest white Onion. Unsurpassed for tenderness and very mild. Pkt., 10c; oz., 40c; 1/4 lb., \$1.25; lb., \$4.00, postpaid.

SOUTHPORT RED GLOBE. The best round red Onion. Pkt., 8c; oz., 25c; $1 / 4$ lb., 75c; lb., \$2.50, postpaid.

SOCTHPORT WHITE GLOBE. Extra select; the best round white Onion. Always brings a fancy price on the market. Pkt., 10c; oz., 40c; $1 / 1 / 1 b ., \$ 1.10$ lb., \$3.75, postpaid.

SOUTHPORT YELLOW GLOBE. The favorite round yellow Onion with the big Onion growers. Attractive in appearance and an immense cropper. Pkt., 8c; oz., 25c; $1 / 4$ lb., 75c; lb., \$2.50, postpaid.

WHITE PORTUGAL OR SILVERSKIN. The standard flat white Onion; bulbs grow to good size; mild and of fine flavor. Grown extensively for winter use and for sets and pickling Onions. For sets or pickling size, sow 1 lb. of seed to each 100 feet of drill. Pkt., 10c; oz., 35c; 1/4 lb., \$1.00; 1b., \$3.50, postpaid.

YELLOW GLOBE DANVERS. The most popular yellow Onion. Not quite as globe shaped as Southport. Pkt., 8c; oz., 25c; 1/4 lb., 70c; lb., \$2.25, postpaid.

YELLOW FLAT DANVERS. Ripens earlier than the globe shaped varieties. The only variety used extensively for producing the yellow bottom sets. Pkt. 8 c; oz., 25c; 1/4 lb., 75c; lb., \$2.50, postpaid.

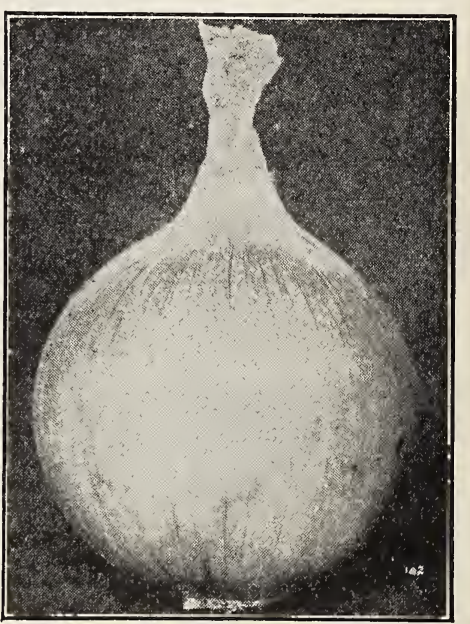

Southport White Globe

\section{Frost-Proof Onion Plants}

The demand for hardy Frost-Proof Onion Plants is increasing rapidly each season, for planters find they can mature a much larger and finer Onion from the plants than can be matured from sets. Set them out as soon as the ground thaws out in the spring. Frost and light freezes actually help to make a fine, firm Onion. We can supply Frost-Proof Onion Plants in the White Bermuda variety only, and from December 1st to May 1st, only. All plants are packed in bunches of 100 , and we sell in even hundreds only. 100 for $\mathbf{7 5 c ;} 500$ for \$2.50; 1,000 for \$3.75, postpaid.

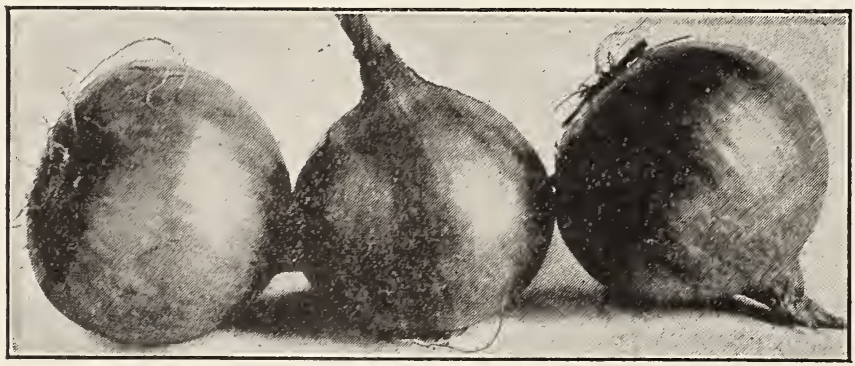

Southport Red Globe

\section{Save Money on Your Onion Seed}

If you are going to plant a quantity of Onion or other seed, you can save money by taking advantage of the Wholesale Prices, as given on pages 76,77 and 78 of this catalog.

After you have ordered your seeds, we would consider it a great favor if you would lend this copy of Burgess' Seed and Nursery Book to a friend or neighbor of yours who might be interested in gardening. We will be glad to mail you another copy of our book at any time. 


\section{Burgess' Michigan Grown Peas}

One pound of seed for 50 feet of row; 120 to 180 lbs. per acre.

\section{Drought-Proof Pea}

\section{Laughs at Drought, Smiles at Rain}

Burgess' Drought-Proof will do well under a wider range of weather and soil conditions than any other variety. It will grow a crop during the driest, hottest summer months, at a time any other variety would be a failure. In the hot, dry localities of the West this variety will grow a large crop without irrigation and without a single drop of rain falling upon it from seed time to harrest. For mid-summer or late summer planting this is the variety to plant. If it rains and the soil is kept moist this variety will produce as large a crop as any variety we know of; if it doesn't rain, and it gets hot and dry, you will get a crop anyway. The handsome round pods are well filled with from 7 to 10 peas in a pod; quality excellent, sweet and tender, even when the peas are large. Vines grow 2 feet high, and require no support. This is the pea that will do its best in the North, South, East or West. Don't fail to give it a trial. Pkt., 10c; $1 / 2$ lb., 30c; lb., 55c; 2 lbs., $\$ 1.00$, postpaid.

ATASKA. Our strain of this variety is the earliest Pea grown. Exceedingly productive, can be planted as soon as ground thaws out in the spring. Height $2 \mathrm{ft}$. Pkt., 10c; 1/2 lb., 22c; 1b., 40c; 2 lbs., 75c, postpaid.

AMERICAN WONDER.

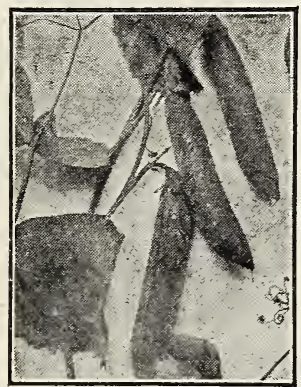

Laxtonian

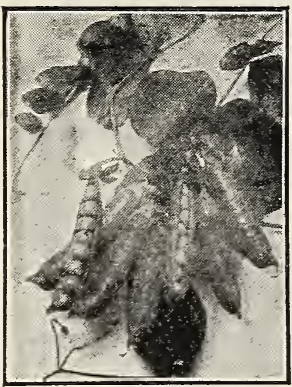

Hundredfold

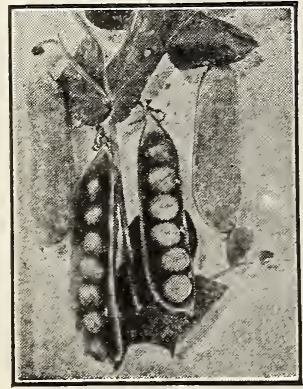

Little Marvel One of the finest early Peas; exceedingly
dwarf, only 10 to 12 inches tall, and a few days later than Alaska. Pkt., 10c; $1 / 21 b$. $22 \mathrm{c} ;$ lb., $40 \mathrm{c} ; 2$ lbs., 75c, postpaid.

LITTLE MARVEL. The earliest wrinkled Pea, and the most productive extra-early wrinkled variety. Vines grow 15 inches high and are heavily set with well filled pods. Pkt., 10c; $1 / 2$ lb., 25e; lb., 45e; 2 lbs., 85c, postpaid.

PREMIUM GEM. (Improved Little Gem). One of the most popular early varieties: height 12 to 15 inches and very productive. Same season as American Wonder; only 2

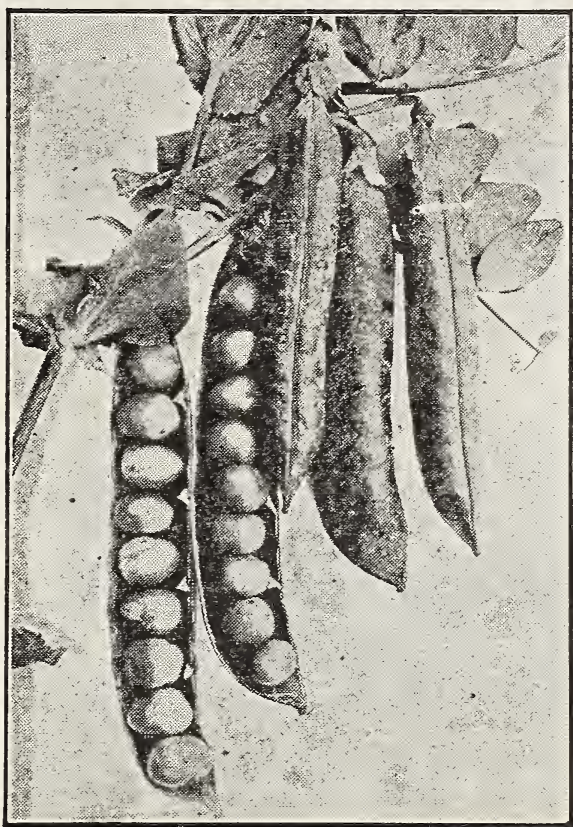

Burgess' Drought-Proof or 3 days later than Little Marvel. Pkt., 10c; 1/2 1b., 22c; 1b., 40c; 2 lbs., 75c, postpald. THOMLS LAXTON. Only a few days later than American Wonder and Premium Gem, but pods and peas much larger. Unsurpassed for quality; very productive, vines $2 \frac{1 / 2}{2}$ feet. Similar to Gradus, but earlier and better, so we have discontinued growing Gradus. Pkt., 10c; $1 / 2$ lb., 25c; 1b., 45c; 2 lbs., 85c, postpaid.

HUNDREDFOLD. This Pea may be described as an improved Laxtonian, which it resembles very much, but is a little larger and more prolific. Pods $31 / 2$ to 4 inches long and well filled with large deep green Peas of finest quality. Vines 16 to 18 inches. Peas mature only a few days following Thomas Laxton. Pkt., 10c; $1 / 2$ lb., 25e; lb., 4ac; 2 lbs., 85c, postpaid.

LAXTONIAN. Same season as Hundredfold; vines 15 to 18 inches; peas of superb quality and large size and 8 to 10 in a pod. Pkt., 10c; 1/2 1b., 22c; lb., 40c; 2 lbs., 75c, postpaid.

HORSFORD'S MARKET GARDEN. The most productive second-early or main crop variety; about a week later than Laxtonian; and a most profitable variety for market gardeners. Excellent quality; height 2 feet. Pkt., 10c; 1/2 lb., 22c; lb., 40c; 2 lbs., 75c, postpaid.

TELEPHONE. A leading mid-season variety and very popular with market gardeners whose trade appreciates fine appearance and high quality. Pods $4 \frac{1 / 2}{2}$ to 5 inches long and filled with large peas which are tender, sweet and of excellent flavor. Height $3 \frac{112}{2}$ to 4 feet. Pkt., 10c; $1 / 2$ lb., 22c; lb., 40c; 2 lbs., 75c, postpaid.

IIPROVED STRATAGEM, or POTLATCH. The best semi-dwarf main crop variety. Height 2 feet; very robust; requires no support. Very productive and pods borne in elusters near top of vine. Pods large and packed with immense peas of delicious sweetness. Pkt., 10c; $1 / 2$ lb., 25c; lb., 45c; 2 lbs., 85 c, postpaid.

CHAMPION OF ENGLAND. A late variety. Valuable to prolong the season. Very productive and universally admitted to be one of the richest and best flavored of the late Peas. Height 4 to 5 feet; Peas of large size and 6 to 9 in the pod. Pkt., 10c; $1 / 2$ lb., 22c; lb., 40c; 2 lbs., 75c, postpaid.

QUITE CONTENT. The largest podded Pea in existence. The vines attain a height of $51 / 2$ to 6 feet and are practically covered with handsome pods that are gigantic in size, measuring 5 to 7 inches in length and containing 9 to 12 large, wrinkled peas of the finest table quality. Superb quality and great productiveness make this a most desirable main crop and late variety for both the market and the home garden. Pkt., 10c; 1/2 lb., 25e; 1b., 45c; 2 lbs., 85c, postpaid.

DWARF GRAY SUGAR. Best edible-podded variety. Cook pods and all like snap beans. Pods much smaller than some of the other edible-podded sorts, but are of considerable better quality and very productive. Very early, being ready for use about the same time as Little Marvel. Height 15 inches. Be sure to plant some of this variety, you will like them. Pkt., 10c; $1 / 2$ lb., 25c; lb., 45c; 2 lbs., 85c, postpaid.

\section{Inoculate Your Peas for Best Results}

Inoculation of seed hastens maturity, increases the yield and enriches the soil. Once tried on garden Peas it will always be used. It is not an expense, but an investment. Garden Size, sufficient for 5 pounds of seed and good for Peas, Sweet Peas, and Beans, 25c: Half Bushel Size (for Peas only) 65c; Bushel Size (Peas only) \$1.00. Inoculation good for Beans only at these same prices. 


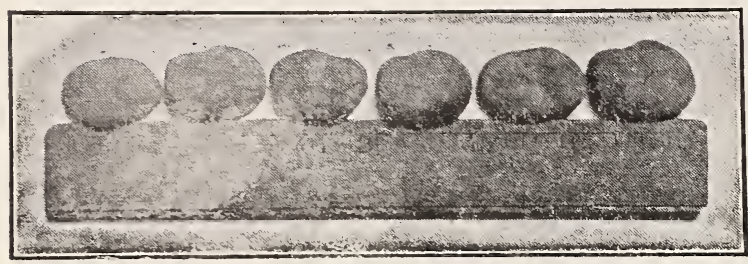

Lima Peas

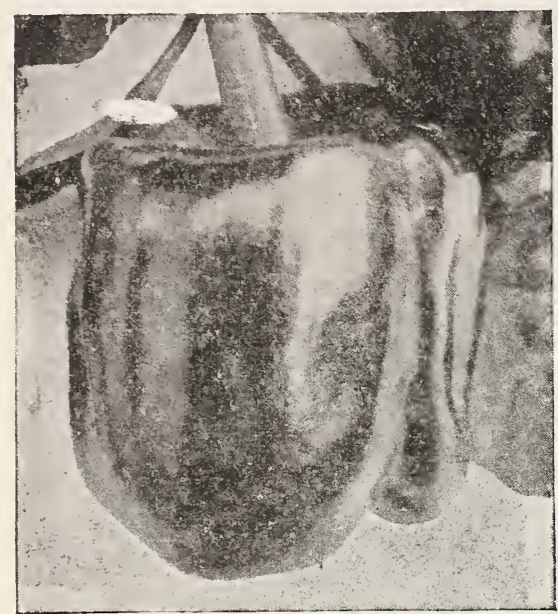

Chinese Giant Pepper paid.

\section{Lima Peas}

This is the most wonderful Pea in the world. The peas are as large as the largest Lima Bean, and nearly the same shape. This pea is very hardy and can be planted as soon as the ground thaws out in the spring. We plant them here a month ahead of any other garden. In growth it is unlike other varieties of peas, for instead of being a vine, it is a bush of upright growth, about 2 feet high, with strong, sturdy stalks. It is wonderfully productive. Botanically it belongs to the Horse Bean family, and has been advertised to some extent as a Giant Butter Bean, but in reality it is more like a pea than a bean. The Lima Pea is a most delicious vegetable, and sure to become as popular as the Lima Bean. We have but a limited amount of the seed, so are selling it in packets only. Pkt., 10c; 3 pkts., 25c; 7 pkts., 50c; 15 pkts., \$1.00, post-

\section{Harris' Earliest Pepper}

One ounce of Pepper will produce 1,500 plants.

Those who have difficulty raising Sweet Peppers should try Farris' Earliest. It is the Pepper for the Northern States where the larger and later kinds do not mature, and for the Southern States where extra early Peppers are wanted. Harris' Earliest always produces a good crop of Peppers even in unfavorable seasons when other kinds produce only a big growth of plant and leaves and but few Peppers. The Peppers mature very early; ripe (red) Peppers the first part of August in the Northern States, and plenty of green Peppers long before that date. The plants are only 15 to 18 inches tall and usually produce so many Peppers that they hardly seem able to support them, often as many as 20 on a single plant. Peppers are $3 \frac{1 / 2}{2}$ to 4 inches in length by $2 \frac{1}{2}$ to 3 inches in diameter; very mild and sweet. If you want Peppers and lots of them plant Harris' Earliest. For the Northern parts of the country it is the only kind that can be relied upon to produce a good crop every season. Some seedsmen are offering southern New Jersey seed, because it can be raised at a much lower cost than the Northern grown seed we offer, but it does not give as good results. You will not regret it if you pay a little more and get our early Northern strain of seed. Pkt., 15c; 2 plkts., 25c; oz., 90c; $1 / 4$ lb., $\$ 3.00$; lb., $\$ 10.00$, postpaid.

CHINESE GIANT. Largest Pepper grown; magnificent appearance; flesh the thickest ever found in any of the large Peppers, superior flavor, very mild. Four to 5 inches broad and are of equal length. Plants well branched and thickly set with enormous fruits. Only a few days later than Ruby King. Pkt., 10c; 3 pkts., 25c; oz., 65c; 1/4 lb., \$1.95, lb., $\$ 6.50$, postpaid.

RUBY KING. The standard Sweet Pepper for home and market. Red Peppers about a month later than Harris Earliest. Pkt., 8c; oz., 40c; $1 / 4$ lb., \$1.25; lb., \$4.00, postpaid.

GOLDEN QUENN. Largest, best and most handsome yellow Pepper; mild and sweet. Same season as Ruby King. Excellent home garden variety. Pkt., 10c; 3 pkts., 25c; oz., 60c; $1 / 4 \mathrm{lb}$., $\$ 1.80 ;$ lb., \$6.00, postpaid.

PIMENTO. The great thick-meated canning Pepper. Sweet as an apple. Only 8 or 10 days later than Ruby King. Pkt., 8c; oz., 45c; 1/4 lb., \$1.40; lb., \$4.50, postpaid.

LONG RED CAYENYE. The leading hot P'epper. Pkt., 8c; oz., 40c; 1/1 lb., \$1.25; lb., $\$ 4.00$, postpaid.

TOBASCO. The hottest of all. Used exclusively for the famous Tabasco Sauce. Pkt., 8c; oz., 45c; $1 / 4$ lb., $\$ 1.40 ; 1 b ., \$ 4.50$, postpaid.

\section{Market Gardeners' Wholesale Prices on pages 76, 77 and 78}

\section{Parsley}

One ounce to 100 feet of row

CHAMPION MOSS CURLED. Finest and most handsome variety. Pkt., 5c; oz., 12c; 1/4 lb.,

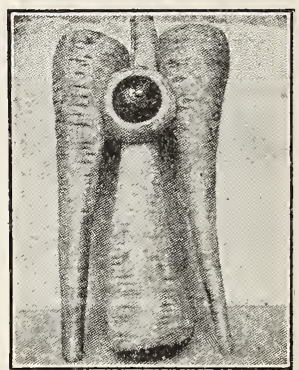

I. H. C. Parsipip $35 \mathrm{c} ; \mathrm{lb.,} \$ 1.00$, postpaid.

TURNIP ROOTED. The edible portion of this variety is the fleshy root, which resembles a small parsnip. Excellent for flavoring soups, stews, etc.

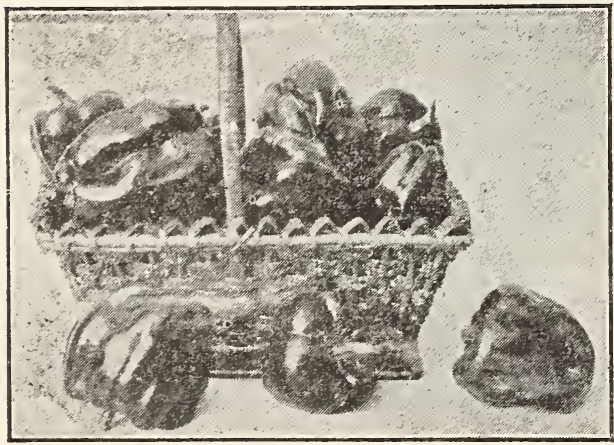
Pkt., 5c; oz., 15c; $1 / 4$ lb. 40c; lb., \$1.25, postpaid.

\section{Parsnip}

One ounce to 150 feet of row; 4 to 6 pounds per acre.

MMPROVED HOLLOW CROWN. The best variety. Pkt., 5c; oz., 12c; $1 / 4$ lb., 35c; lb., $\$ 1.00$, postpaid.

\section{Get Rid of Moles}

\section{See Page 16}

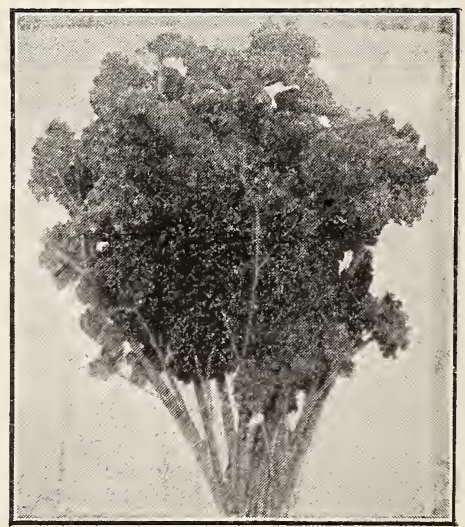

C. M. O. Parsley 


\title{
SAXA RADISH
}

\section{The Earliest Radish Grown}

We have found this new Radish to be earlier than any of the other socalled earliest sorts, and the best extra early variety for forcing or growing in the open ground. From the time of seed sowing to the table in 16 to 18 days, and under ideal conditions are fit to pull in 14 or 15 days. It is round, bright scarlet in color and has a very small top and tap root. Flesh pure white, crisp, brittle, mild and juicy. The Saxa is one of the slowest to shoot to seed. The seed we offer is grown in Michigan, from carefully selected stock seed, which insures earliness and uniformity in color and shape. Pkt., 8c; oz., 15c; 1/1 ib., 45c; lb., \$1.50, postpaid.

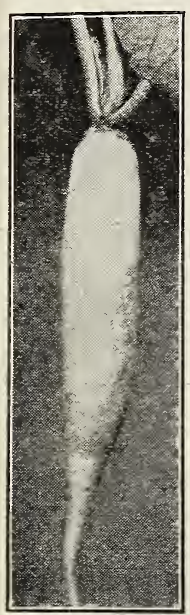

Icicle

\section{Other Varieties of Radish}

\author{
One ounce of seed for 100 feet of row.
}

CRIMSON GIANT. One of the finest Radishes grown. Suitable for forcing or early planting out of doors. Larger than the other round red varieties. Roots free from hollow center or pithy fibre. Pkt., 5c; oz., 12c; $1 / 4$ lb., 35c; lb., \$1.00, postpaid.

EARLY SCARLET TURNIP. Early round red Radish; later than Saxa. Very desirable for early outdoor planting. Pkt., 5c; oz., 12c; $1 / 4$ lb., 30c; lb., 90c, postpaid.

EARLY WHITE TURNIP. The earliest white Radish; always mild and crisp. Pkt., 5c; oz., 12c; $1 / 4$ lb., 35̃c; lb. $\$ 1.00$, postpaid.

EARLY LONG SCARLET SHORT TOP. The best long red Radish. Pkt., 5c; oz., 12c; $1 / 4$ lb., 35c; lb., \$1.00, postpaid.

FRENCH BREAKFAST. Olive shaped; red, white tipped. Pkt., 5c; oz., 12c; $1 / 1 \mathrm{lb}, 30 \mathrm{c}$; lb. 90c, postpaid.

ICICLE. The best long white Radish; mild and sweet. A favorite with market gardeners and for the home.garden. Pkt., 5e; oz., 12c; 1/4 lb., 35̃c; lb., \$1.00, postpaid.

WHITE TIPPED SCARLET TURNIP. A favorite in all markets, owing to its fine appearance. Handsome bright scarlet color with white tip. One of the best early varieties for outdoor sowing; excellent quality. Pkt., 5c; oz., 12e; 1/4 lb., 35c; lb., \$1.00, postpaid.

LONG WHITE STRASSBURG. The best summer Radish, withstanding hot weather the best of any sort. Pure white; firm and brittle. Pkt., 5c; oz., 12c; 1/4 lb., 35c; 1b., \$1.00, postpaid.

LONG BLACK SPANISH. Keeps best and longest of all winter Radishes. Skin coal-black; flesh white and crisp; excellent quality. Pkt., 5c; oz., 12c; 1/4 lb., 35c; lb., \$1.00, postpaid.

SCARLET CHINA. A favorite winter Radish. Very handsome; of medium size; rose color; flesh white. By packing n sand, fresh, crisp radishes may be had all winter. Pkt., 5e; oz., 12c; 1/4 1b., 35c; lb., \$1.00, postpaid.

PRIZE MIXTURE. All the leading early varieties mixed. Pkt., 5c; oz., 10c; 1/4 lb., 30c; lb., 90c, postpaid.

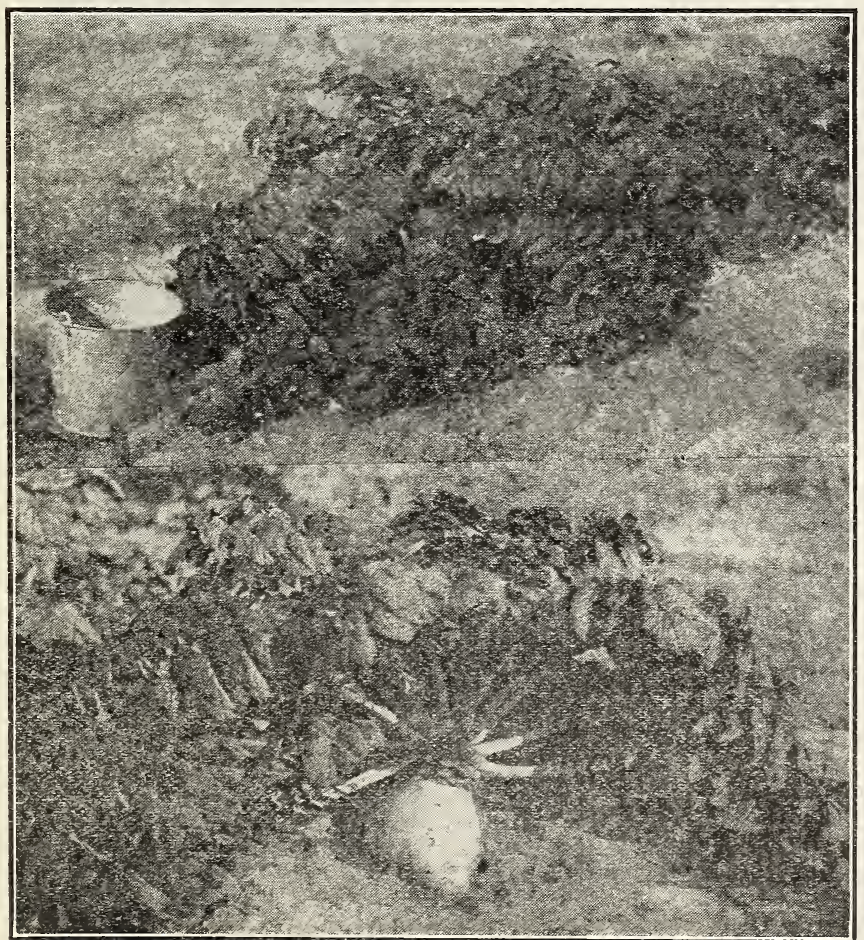

Japanese Giant Radish

\section{Japanese Giant Radish}

The Japanese Radish, or Daikon, as it is known in Japan, is the leading vegetable of Japan, being used as extensively there as the potato is here in America. It is not only eaten raw, but is cooked like Turnips. The Japanese Radishes are of excellent quality and always attract considerable attention on account of their monstrous size.

NERMA LONG, An exceedingly sweetflavored, long white radish. Grows 3 feet long: very crisp and brittle. Fine for all styles of cooking and excellent for pickles. One of the best for eating raw. Pkt., 10c; 3 pkts., 20c; oz., 35c, postpaid.

SARURIJMA. The largest variety of radish in cultivation. Often attains a weight of $\mathbf{1 5}$ lbs. and some grow to more than 30 lbs. Nearly round. A great curiosity and a radish of extraordinary quality. Flesh solid, firm and brittle, and of most excellent flavor. A favorite for fall and winter use, and a valuable winter feed for cattle and poultry. Every poultryman should plant some of them.

Notice the photographs of the Sakurijima Radish on this page The upper photo shows one of these radish plants growing beside a 14-quart water pail. The under photo shows plant with some of the leaves removed. These photos were sent to us by Mr. A. I. Root, the publisher of Gleanings in Bee Culture. The radishes were grown from seed he bought from us. He writes us as follows: "I expect to give vour Japanese. Radish a good write-up in our journal. May be you don't know it, but I believe it's about the best and most rapid-growing plant to furnish green food for chickens that there is out. The chickens will eat not only the green top, but every bit of the radish, if just given a chance. I grew one and had it on exhibition that weighed 13 pounds."

Plit., 10c; 3 pkts., 25e; oz., 35c; 1/4 lb., \$1.10; 1b., \$3.75, postpaid. 


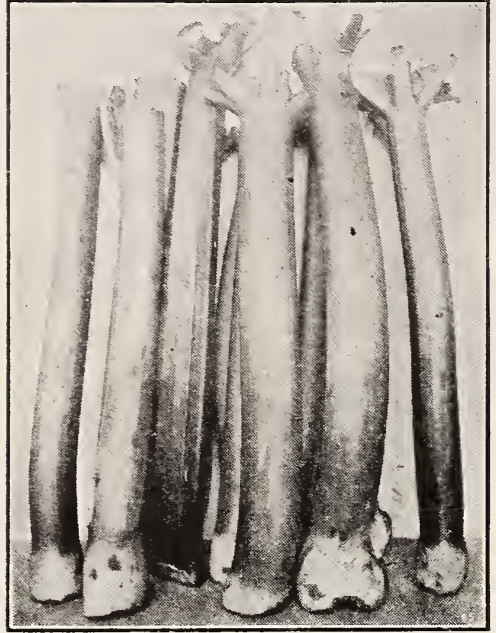

Early Giant Rhubarb

\section{Pumpkin}

One ounce for 20 hills; 3 to 4 pounds per acre.

BIG TOM, or IMPROVED LARGE FIELD. Leading corn field Pumpkin. Smooth, hard, reddish-orange skin, with rich orange-yellow flesh. Wonderfully prolific. Pkt., 5c; oz., 10c; $1 / \frac{1}{4}$ lb., 30c; lb., 90c, postpaid.

JUMBO Often weigh 100 to 300 lbs. Always a prize winner at exhifor feeding purposes. Pkt., 10c; oz., 20c; 1/4 lb., 55c; lb., \$1.75, postpaid.

KENTUCKY FIELD, or SWEET CHEESE. About 2 feet in diameter, round, flattened, hard and productive. Fine for market and family use, and excellent for stock feed. Pkt., 5c; oz., 10c; $1 / 4$ lb., 25c; lb., 75c, postpaid.

SMALL SUGAR. The most popular pie pumpkin. Looks like a Field Pumpkin, but is smaller and of much better quality. Flesh sweet and tender the earliest Pumpkin, matures in 65 days; excellent keeper. Pkt., 5c; oz. 15c; $1 / 4$ lb., 35c; lb., \$1.00, postpaid.

WINTER LUXURY The best pie Pumpkin. Its winter-keeping oval in shape and of medium size. Evenly and finely netted and is a yellowish russet color. Flesh deep golden color, sweet and cooks quickly. A great producer. Pkt., 5c; oz., 15c; $1 / 4$ lb., 40c; lb., \$1.25, postpaid.

\section{Early Giant Rhubarb}

EARLY GIANT is mammoth in size, and the best and earliest variety. It is the first vegetable from the ground in the spring and the easiest of all perennial plants to grow. A half dozen plants will supply a large family during the season, and plants well established will last for years. There always is a big demand and as a money maker with very little work and expense, we recommend Early Giant Rhubarb. We offer a fine stock of roots this season. 35c each; 3 for $75 \mathrm{c} ; 6$ for $\$ 1.25$; 12 for $\$ 2.25$, by parcel post, postpaid. By express, not prepaid, \$4.50 per 50 or $\$ 8.00$ per 100 .

We always recommend the planting of Rhubarb roots instead of seed, but if seed is wanted, we can supply seed of the genuine Early Giant at 10c per packet; 30c per oz; 90c per 1/1/ lb.; or \$3.00 per lb., postpaid.

\section{Salsify or Vegetable Oyster \\ One ounce to 75 feet of row.}

MAMMOTH SANDWICH ISIAND. The best variety. Pkt., 10c; oz., 30c; $1 / 1 \mathrm{lb}$, $80 \mathrm{c} ;$ lb., \$2.75, postpaid.

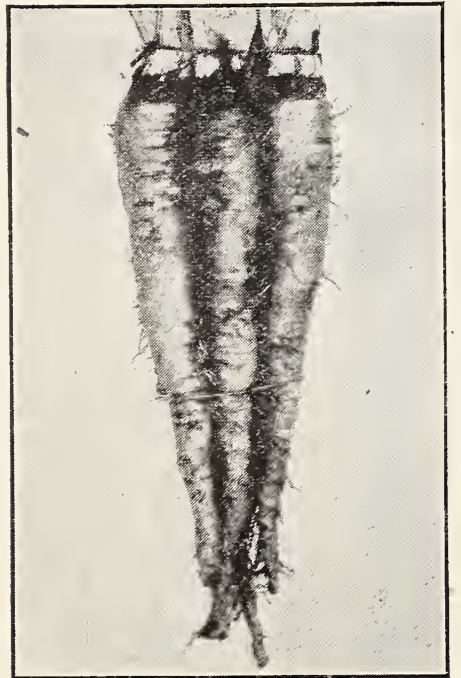

Salsify

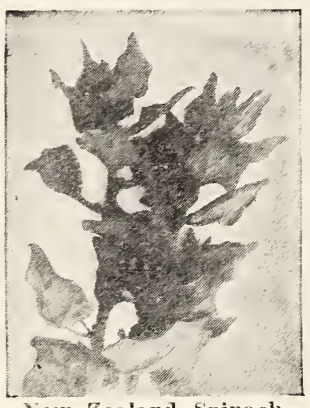

\section{Spinach}

One ounce to 100 feet of row.

KING OF DENMARK. A valuable new variety. Leaves are large, crumpled, deep green: very early, yet remaining in good condition a week or two after other kinds have run to seed. Pkt., 5c; oz., 10c; $1 / \frac{1}{1} \mathrm{lb.}$, 20c; lb., 60c, postpaid.

MONSTROUS VIROFLAX, or THICKLEAF. A variety bearing thick leaves, measuring up to 10 inches in length and 8 inches wide. Plants measure 24 to 30 inches across on highly fertilized land. Grows more rapidly than other kinds, so can be used earlier. Pkt., 5c; oz., 10c; 1/4 lb., 20c; lb., 60e, postpaid.

VICTORIA. A large-growing variety which is noted for its dark green leaves and ability to withstand hot weather. Leaves are only slightly crumpled, and of finest quality. It is a heavy yielder, probably the most popular variety, and unexcelled for spring or fall sowing. Pkt., 5c; oz., 10c; $1 / 41 b ., 20 c ; 1 b ., 60 c$, postpaid.

NEW
ZEALAND or

\section{EVERBEARING}

A distinct type of Spinach with s m a ll green leaves, wh i c h $\mathrm{m}$ a kes large, bushy plants, often 3 feet in diameter. O n ly the young leaves and tips of the branches are used, and the more they are picked the faster the plant seems to grow. It will give you fine greens from your garden all summer and fall. Especially suited to dry and arid locations where other varieties do not do well, and the only kind that can be successfully grown in extremely hot weather. Pkt., 5c; oz., 12c; $1 / 4$ lb., 35e; lb., \$1.00, postpaid.

\section{SPECIAL PRICES}

to Market Gardeners on

Pages 76, 77 and 78

\section{SEA KALE}

\section{(Celery-Asparagus)}

One ounce will produce about 200 plants.

Sea Kale is a wonderful vegetable which is practically unknown in this country but, owing to its extraordinary merit, is worthy of general cultivation. It is a perennial which dies down each fall and comes up again in the very early spring, ahead of Asparagus. It is cultivated somewhat like Asparagus, and it takes about the same length of time to get a bed well established. Its blanched stalks are cooked like asparagus and are ready for use earlier than Asparagus. These shoots can also be had during the winter by digging the roots and forcing them in the same way as Witloof Chicory, which you will find explained on page 10. The leaves are also used for greens. It is one of the most delicious of all vegetables; combines the flavor of Asparagus with that of Celery; and coming so early in the season makes it especially desirable. Sea Kale comes usually from seed but can be grown from offsets or root cuttings. It can be grown any where and should be in every garden. Don't fail to get a bed started this season. Pkt., 15c; 2 pkts., 25c; oz., 65c, postpaid. 


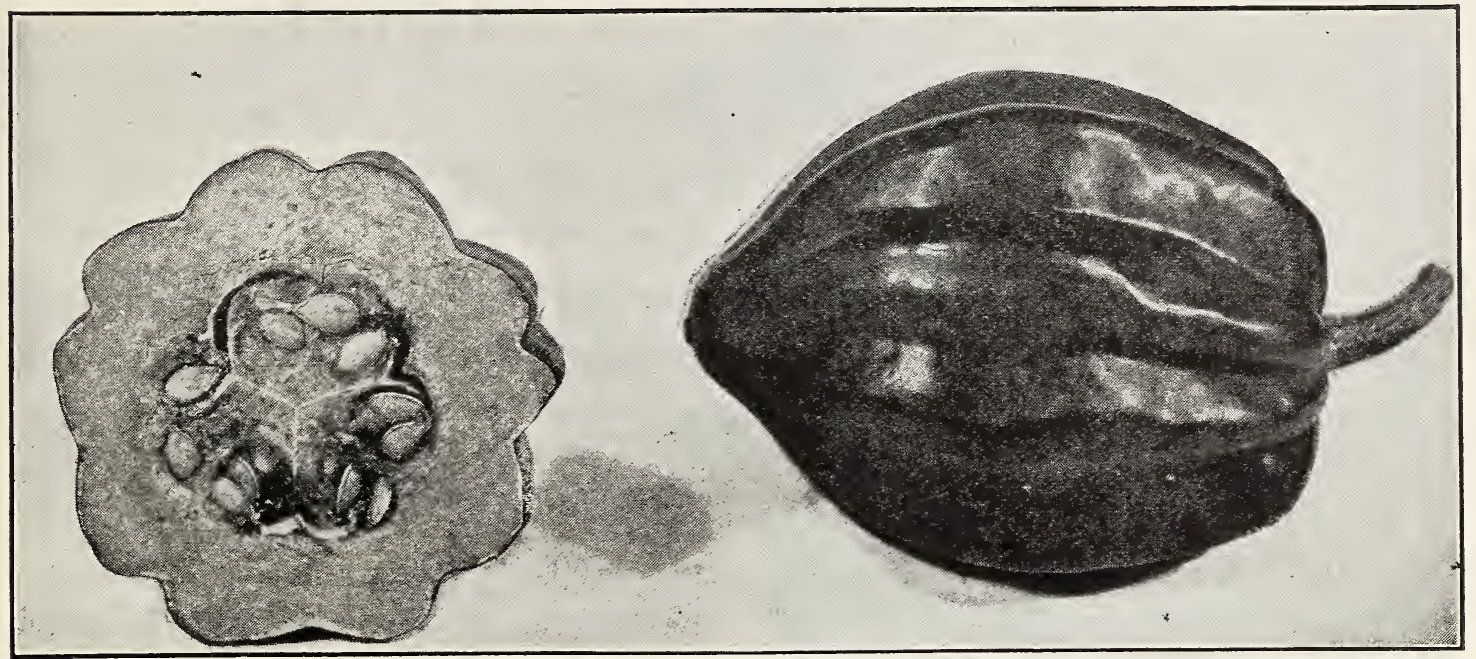

Table Queen Squash

\section{Squash}

Summer Squash-One ounce to 25 hills; 3 to 4 lbs. per acre.

Winter Squash-One ounce to 10 hills; 3 to 4 lbs. per acre.

TRUE HUBBARD. The old stand-by, and the most popular winter variety. Pkt., 8c; oz., 15c; $1 / 4$ lb., 45c; lb., \$1.40, postpaid.

CHICAGO WARTY HUBBARD. Preferred by many to True Hubbard. Popular with market growers catering to a fancy trade. Pkt., 8c; oz., 15c; 1/4 lb., 45c; lb., \$1.50, postpaid.

BLUE HUBBARD. A large Squash of the Hubbard shape, but the color is blue-gray. Extra thick meated; excellent quality; keeps as well as other Hubbards. Pkt. 8c; oz., 15c; 1/4 lb., 45ce; lb., \$1.50, postpaid.

GOLDEN OR RED HUBBARD. A week earlier than True Hubbard, and of the same shape and quality. Pkt., 8c; oz., 15c; 1/4 lb., 45c; lb., \$1.50, postpaid.

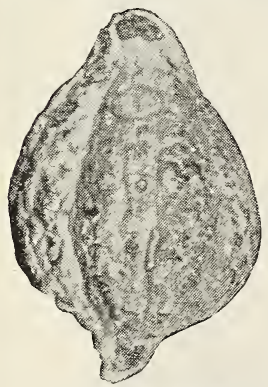

Blue Hubbard

Cocozelle, or Italian Marrow, is one of the most delicious additions to the Squash family that has been introduced in years. For piquancy of flavor, tenderness and general palatability it has few equals. It is easy to grow, and well worth a place in every garden. This plant does not make a vine, but grovs in the form of a compact bush, and as only 5 or 6 hills is sufficient for a large family, very few gardens are so small that room cannot be found to grow it. The oblong green fruits should be picked when not more than 4 to 6 inches long. If the fruits are allowed to grow larger they lose their delicacy of flavor, and when one fruit is allowed to mature it checks the formation of any more fruit on the plant. The fruits form and grow rapidly and may be picked almost every day until frost. If planted early it will fruit from the latter part of June until October. Can be cooked like Asparagus or Squash, and most excellent when prepared like French fried potatoes. Pkt., 10c; oz., 20c; 1/4 lb., 55c; lb., \$1.75, postpaid.

MARKET GARDENERS and others sowing seed in quantity can save money by referring to page 76

Pkt., 8c; oz., 15c; $1 / 4$ lb., 45c; lb., \$1.50, postpaid.

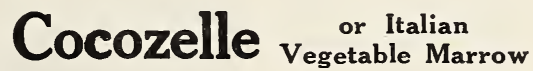

\section{New Table Queen}

Surely a Squash fit for a Queen's taste. Cut in half and aked for 20 minutes it will give you a delicious meal you Table Queen. You will be pleased, not only with the he fruited, the vines being so vigorous and productive. 4 to 5 inches in diameter. The meat is exceptionally dry and mealy and of extra fine flavor. The shell is thin, but hard and smooth, and they keep as well as the Hubbard, although they ripen earlier. The color is dark green, alend. This fine Squash has rapidly come into favor in many markets, being preferred to the large sorts, while for the home garden it is ideal. Pkt., 10c; oz., 20c; $1 / 4$ lb. $55 \mathrm{c} ;$ lb., $\$ 1.75$, postpaid.

DEIICIOUS For sweetness, richness of flavor and extraordinary quality, it is unsurpassed. usually weigh 5 to $10 \mathrm{lbs}$; rind dark green, mottled in lighter shades; dark orang $\in$ flesh, very

MAMMOTH WHITE BUSH SCALLOP. The best Summer Squash for shipping to distant mar- 


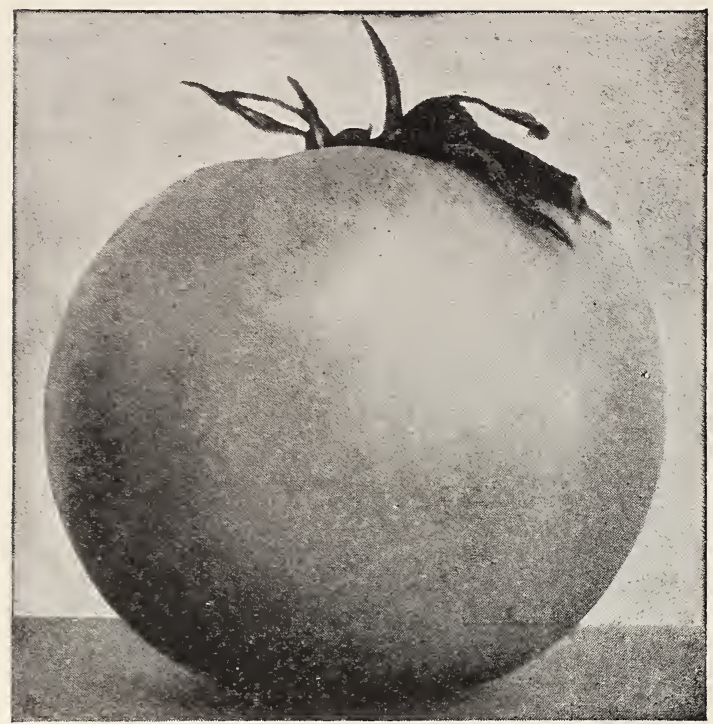

Burgess' Earliest and Best Tomato

\section{Tomato}

Every season sees a big increase in the demand for our Michigan grown Tomato seed. Climatic conditions in Michigan are conducive to freedom from disease, to the production of fruit instead of vine, and to early maturity. Our strains keep these tendencies to a marked degree when planted elsewhere. A trial will convince you of the superiority of our Michigan grown Tomato seed.

One ounce of seed will produce about 2,000 plants.

\section{Burgess' Earliest and Best \\ The Earliest and Best Tomato on Earth}

Burgess' Earliest and Best Tomato is the earliest and best variety grown. Not only will it produce large, beautiful solid shipping Tomatoes earlier than any other variety, but it produces the most perfect High Crown Tomatoes ever grown, and entirely free from core. No cripples, no scalds, no blight, no cracked, no wrinkled, no one-sided, uneven, scarred fruit and when dead ripe they will not burst.

Not only is it the most beautiful bright red Tomato you ever saw, but it also has the finest flavor.

It is almost seedless. A marvelous stem setter; often ten fruits in first cluster, and all solid and meaty.

It has just enough foliage-will stand plenty of manuring without going to vine.

It is the most perfect shipping Tomato ever grown.

Being such a tremendous yielder, it can be gathered in one-half the time of any other Tomato, and peelers can prepare three bushels to one bushel of any other variety.

Just think of it! A Tomato earlier than Earliana and better than Stone. It is of the John Baer type, and might be termed an extra-early improved strain of that variety. On our Michigan seed farms it ripens fully two weeks earlier than the much advertised Burbank Tomato, and so much better that for quality there is no comparison. If you can grow but one variety, let that one be Burgess' Earliest and Best. Pkt., 10c; 3 pkts., 25c; oz., 50c; 1/4 1b., \$1.50; lb., $\$ 5.00$, postpaid.

BONYY BFST. A favorite bright scarlet early variety, maturing a little later than Earliana. Pkt., 5c; oz., 35c; $1 / 4$ lb., $\$ 1.00$; 1b., $\$ 3.50$, postpaid.

CANADA RED. A new extra-early variety from the frigid North. Five days earlier than the famous Earliana, more productive and of finer quality. Pkt., 10c; oz., 50c; 1/4 lb., \$1.50; 1b., \$5.00, postpaid.

CHALK'S EARLY JEWEL. Large, scarlet, smooth fruits; considered by many to be the best. second-early sort. Pkt., 5c; oz., 35̃c; $1 / 4$ lb., $\$ 1.00 ; 1$ b., $\$ 3.50$, postpaid.

COOPER'S SPECIAL. An improved strain of Livingston's Globe. Fruits purple; globe shaped. It yields heavier than Globe and its carrying qualities are equally as good. A most wonderful variety for the Southern planter. Matures earlier than most main crop sorts and keeps on bearing almost until frost. Pkt., 10c; oz., 60c; 1/4 1b., \$1.80; 1b., \$6.00, postpaid.

DWARF STONE. The best of the dwarf growing sorts. The fruits, which hang well up off the ground, are nearly as large as those of the original Stone, and excellent in quality, smooth, meaty and solid. Dwarf varieties do not produce as many fruits to the plant as the larger sorts, but owing to their small size and upright growth twice as many plants can be set in the same garden space. Pkt., 10c; oz., 60c; 1/4 lb., \$1.80; 1b., \$6.00, postpaid.

EARLIANA. The most popular extra-early Tomato. Yields well; fruit bright red, solid and of fine quality. Our strain of this variety is extremely early and is much superior to seed produced farther South. Pkt., 10c; oz., 50c; $1 / 4$ lb., \$1.50; 1b., \$5.00, postpaid.

GOLDEN QUEEN. The leading yellow Tomato. Many consider it of better flavor than any of the red varieties, and it is less acid. Pkt., 10c; oz., 50c; 1/4 lb., \$1.50; 1b., \$5.00, postpaid.

JUNE PINK. The earliest pink variety. Only 2 or 3 days later than Earliana, but larger, and of better quality. Pkt., 10c; oz., 50c; $1 / 4$ lb., \$1.50; lb., \$5.00, postpaid.

LIVINGSTON'S GLOBE. One of the most popular main crop varieties. The leading variety in the South for shipping to Northern markets. Pkt., 10c; oz., 50c; 1/4 1b., \$1.50; 1b., \$5.00, postpaid:

NORTON WILT-RESISTANT. From many parts of the country have come reports of the loss of Tomato crops because of wilt. The United States Department of Agriculture started the breeding of wilt resistant varieties and the Norton is regarded as the best. If you are bothered with wilt in your locality, you will be interested in this variety. The Norton resembles the Stone in appearance and bearing season. Fruits very firm, solid, smooth and of very fine flavor. Pkt., 10c; oz., 60c; 1/4 lb., $\$ 1.80$; lb., \$6.00, postpaid.

PONDEROSA. With the exception of Colossal, this variety is the largest Tomato grown; very few seeds; excellent quality. Pkt., 10c; oz., 65c; $1 / 4$ lb., \$2.00; lb., \$6.50, postpaid.

STONF, The old stand-by. Large, bright red, perfectly smooth, main crop Tomato. Pkt., 5c; oz., 30c; $1 / 4$ lb., 80c; lb., \$2.75, postpaid.

YELLOW PEAR. Small yellow fruits; pear shape; very sweet. Fine for preserves and eating out of hand. Pkt., 10c; 3 pkts., 25c; oz., 60c, postpaid.

SMALI. FRUITED AND PRESERVING. All kinds of small fruited preserving varieties mixed; all shapes and colors. Interesting and useful. Plant a few for the children. Pkt., 10c; 3 pkts., 25e; oz., 60c, postpaid.

MARKFT GROTVERS If you want to be the first on MARLI GROWLIS the market with Tomatoes of the best quality, you will make no mistake if you purchase our Michigan grown seed. For wholesale prices to market growers see pages 76,77 , and 78 .

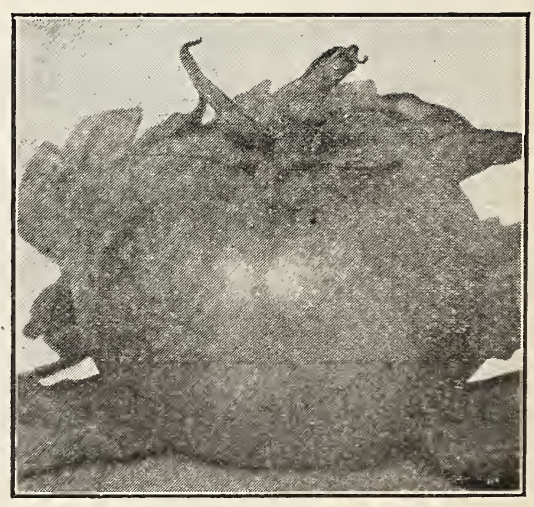

Norton Wilt-Resistant 


\section{Colossal}

\section{The Largest Tomato Grown}

This is the largest of all Tomatoes, being even larger than the famous Ponderosa. Many planters, in different parts of the country have grown Colossal Tomatoes weighing over 3 lbs., and some more than 4 lbs. Not only does the Colossal produce giant fruits, but it produces them in abundance. One planter in Illinois raised over a ton of Tomatoes from 186 plants. The very thick, meaty flesh, few seeds, and mild flavor combine to give the Colossal a quality on a par with its immense size. Unsurpassed for slicing or canning. Pkt., 20c; 3 pkts., 50c; oz., \$1.00, postpaid.

Yellow Colossal The largest yellow Tomato; in color, which is a beautiful golden yellow. Pkt., 20c; 3 pkts., 50c; oz., \$1.00, postpaid.

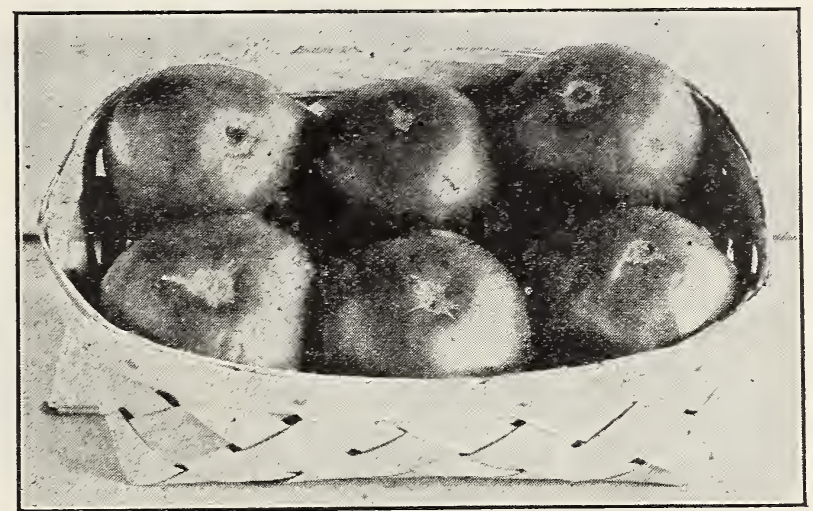

Colossal

White Beauty Ivory-white in color and the flesh is almost paper white. This new white variety is of medium who have

\section{Tobacco}

One ounce will produce about 5,000 plants.

Grow your own Tobacco and have a good supply of pure, unadulterated natural leaf that has not been "doped" or "doctored" up by the manufacturer. A packet or two of seed will grow enough to supply most anyone.

FINE HAVANA. Choice seed from an extra select strain; large leaf; one ô the earliest. Pkt., 10c; oz., 45c; $1 / 4$ lb., $\$ 1.50 ; 1 b ., \$ 5.00$, postpaid.
CONNECTICUT SEED LEAF. The leading variety in the Northern and Middle States. Can be successfully grown even in the far North. Pkt., 10c; oz., 45c; $1 / 4$ lb., $\$ 1.50$; 1b., \$5.00, postpaid.

MPROVED WHITE BCRLEY. Extra select strain. Popular variety for chewing. Pkt., 10c; oz., 45e; $1 / 4 \mathrm{lb}$., $\$ 1.50 ;$ lb., $\$ 5.00$, postpaid.

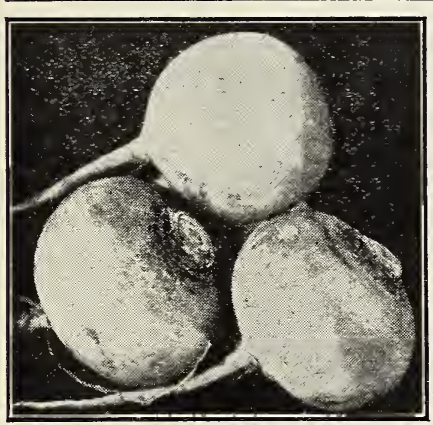

Purple Top White Globe

\section{Turnips}

One ounce to 100 feet of row; $11 / 2$ to $3 \mathrm{lbs}$. per acre.

AMBER GLOBE. The best large yellow late sort. Skin light yellow; flesh yellow, firm and sweet. Fine for table use and stock feeding. A good cropper and keeps in perfect condition until spring. Pkt., 5e; oz., 10e; 1/4 lb., 25̃e; lb., 75c, postpaid.

ORANGE JELLY, OR GOLDEN BALL. The best early yellow Turnip. Not of large size, but firm and of excellent flavor. Keeps well. Pkt., 5e; oz., 10c; 1/4 1b., $25 \mathrm{c}$; lb., 75c, postpaid.

EXTRA EARLY PURPLE TOP MILAN. The earliest Turnip grown. The bulb is flat, of medium size; white, with a bright purple top; and in quality the best. Planted extensively for first market crop, but not so well suited for summer planting. Reaches marketable size in 50 days. Pkt., 5c; oz., 15c; 1/4 1b., 35c; 1b., $\$ 1.00$, postpaid.

EARLY PURPLE TOP STRAP LEAF. The standard early variety Roots broad and flat, of medium size; white, purple top. Extensively sown for both table use and stock feeding. Pkt., 5c; oz., 10c; 1/4 lb., 25c; 1b., 75c, postpaid.

PURPLE TOP WHITE GLOBE. The most popular white Turnip for fall and winter use. Flesh pure white, fine grained and of fine flavor. Heavy yielder and splendid keeper. Desirable for table or stock. Pkt., 5e; oz., 10c; $1 / 4$ lb., 25 c; lb., 75c, postpaid.

WHITE EGG. A quick growing, egg-shaped, smooth, pure white variety. Flesh firm, sweet and mild. Adapted to either spring or fall sowing. Pkt., 5c; oz., 10c; 1/4 lb., 25c; lb., 75c, postpaid.

COW HORN. 12 to 15 inches long by 3 inches across; white, green top; grow partly above the ground; sweet and of fine flavor. Very valuable as a soil enricher. Can be sown broadcast on stubble ground, will grow on poor, worn-out soils, and if plowed under will enrich it as much as a crop of clover. Pkt., 5c; oz., 10c; 1/4 1b., 25c; lb., 75c, postpaid.

\section{Japanese Mammoth Turnip}

SHOGOIV MAMIOTH. The largest of all Japanese Turnips; frequently grow to more than 15 pounds. Round, pure white, very quently grow to more than 15 pounds. Round, pure white, very
solid and sweet. The best keeper, a good table variety, and an excellent feed for cattle. Pkt., 10c; oz., 30c; 1/4 lb., 90c; lb., \$3.00, postpaid.

\section{Rutabagas, or Swedes}

Rutabagas require a longer season than turnips, so should be sown earlier, or about the middle of June.

One ounce for 200 feet of row; 1 to $11 / 2$ lbs. per acre.

IMPROVED PURPLE TOP YELLOW. The best yellow variety; fine flavor. Pkt., 5c; oz., 10c; 1/4 lb., 25c; lb., 75c, postpaid.

MONARCH OR ELEPHANT. Mammoth yellow variety; yields enormous crops. Grown principally for stock feeding, but is good for table use. Pkt., 5c; oz., 10c; 1/4 lb., 25c; lb., 75c, postpaid.

SWEET RUSSIA. Excellent keeper; flesh white, very firm and oweet. Pkt., 5c; oz., 10c; $1 / 4$ lb., 25c; lb., 75c, postpaid.

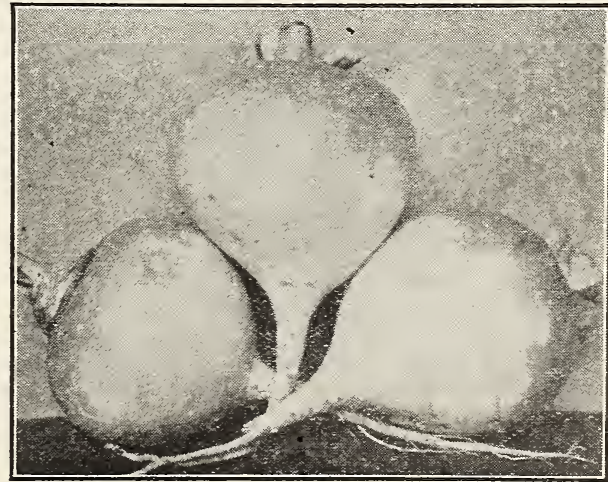

Improved Purple Top Eellow Rutabaga 


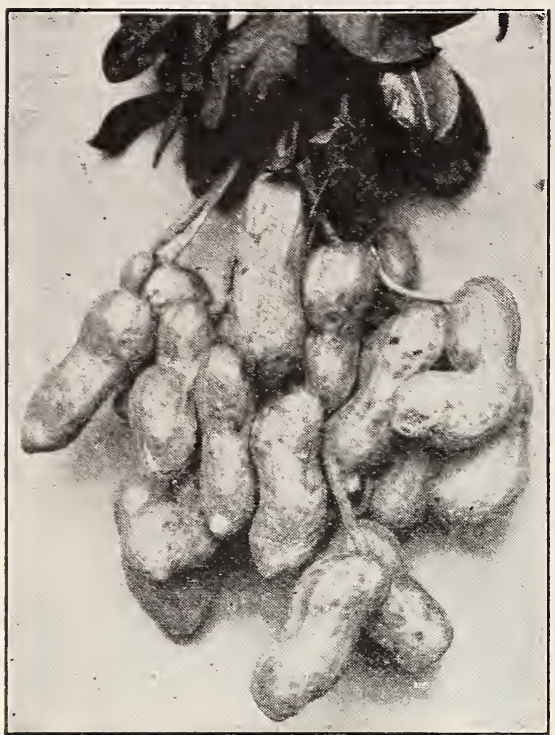

Northern Peanuts

\section{Northern Grown Peanuts}

Just as good Peanuts can be grown in the Northern States as in the South, provided you plant Improved Early Spanish. Every one should plant at least a few for the children.

This is the earliest variety grown, and very productive. The pods are small, but remarkably solid and well filled with nuts of the very finest quality. Boys, here is a chance for you. Think of growing peanuts in your own garden and having plenty of them to eat. Shell nuts carefully so as not to break inside skin, and plant as soon as ground becomes warm, about 2 inches deep, in rows 3 feet apart, and from 8 to 10 inches apart in the row. Pkt., 10c; pt., 25c; qt., 40c; 3 qts., \$1.10; 6 qts., $\$ 2.00$, postpaid.

\section{Ground Almonds}

The Ground Almond, or Chufa, has a fine flavor, resembling the Coconut or Almond. The meat is snow-white, covered with a thin shell or skin of brown color. It grows close to the surface. Is very prolific, a single nut yielding from 200 to 300 nuts in a hill and will do well in any kind of soil. If the nuts are planted in the spring the same as potatoes a big crop can be expected about potato harvest time. They grow so rapidly and produce such immense crops that you will be surprised. Plant some for the children. Everybody likes them. Pkt., 10c; 3 pkts., 20c; $1 / 2$ lb., 40c; lb., 75c; 3 lbs., \$2.00; 10 lbs., \$5.00, postpaid.

\section{Vine Peach}

In the West and Northwest, where fruit is scarce, the Vine Peach is becoming popular. It is easily cultivated, wonderfully prolific, and can be used in every way in which you would use a peach, except that it is not usually liked raw. The vine on which they are borne is somewhat similar to the muskmelon vine, and requires the same cultivation. The fruit is about the size of a large peach, and is of a bright orange yellow color, somewhat russety.

A jar of these cut in halves and cooked in syrup presents a beautiful and tempting appearance. Pkt., 10c; 3 pkts., 25c; 7 pkts., 50c, postpaid.

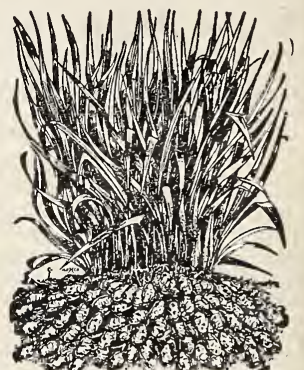

Ground Almonds

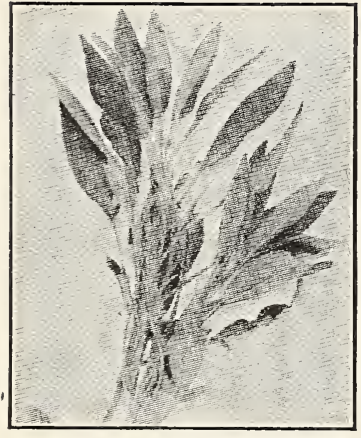

Sage

\section{Herb Seeds and Plants}

They take up so little room, and as they are almost indispensable for savory cooking, a few should be planted in every garden. If they are to be used during the winter, the stalks should be cut on a dry day, when not quite in full bloom, and dried quickly in the shade. When dry they should be packed closely in air-tight boxes. Varieties marked with an asterisk $(*)$ are penennial.

ANISE. Used for garnishing, seasoning and for cordials. Pkt., 8c; oz., \$25c.

BASIL, Sweet. Leaves used for flavoring soups, stews and highly seasoned dishes. Pkt., 8c; oz., 25c.

BORAGE. Leaves used for flavoring. Pkt., 8c; oz., 25c.

*CARAWAY. Seeds used for flavoring pastry, meats, etc. Pkt., 5c; oz., 15c; 1/4 1b., 40c.

*CATNIP, or CATMINT. Leaves and young shoots used for seasoning. Tea made from the dried leaves is good for colds and indigestion. Grown for the bee pasture and for cats. Said to be a "cure-all" for cat diseases. Pkt., 10c; 3 pkts., 25c. Plants, 20c each: 3 for 40c; 12 for $\$ 1.00$, postpaid.

CORIANDER. Seed used for flavoring. Pkt., 5c; oz., 15c.

DLLL. Leaves used for flavoring pickles, soups and sauces. Pkt., 5c; oz., 12c; 1/4 1b., 35c; lb., $\$ 1.00$.

*FENNEr, Sweet. The leaves, boiled, are used for fish sauces, and are beautiful for garnishing. The seeds are used for flavoring. Pkt., 8c; oz., 25c.

*HYSSOP. The flower summits and leaves are used as a remedy for asthma and catarrh. A stimulant, expectorant and mild tonic. Pkt., 8c; oz., koc.

* IAVENDER (Iavendula Vera). True Lavender. The leaves are sometimes used for seasoning, but the plant is chiefly grown for its flowers which are used in the making of perfumes. The dried flowers and leaves are fine for perfuming dresser drawers and linen closets, filling soft cushions, etc. Pkt., 10c; 3 pkts., 25c; oz., $60 \mathrm{c}$.

*LAVENDER (Lavendula Spica). Not quite as strong as Lavendula Vera. Pkt., 8c; 3 pkts., 20c; oz., 40c.

MARJORAM, Sweet. Leaves and ends of the shoots used for flavoring in summer, and also dried for winter use. Pkt., 8c; 3 pkts., 20c; oz., 40c.

*ROSEMARY. Leaves used for seasoning. The oil is valuable in neuralgia, rheumatism and lumbago. Pkt., 10c; 3 pkts., 25c; oz., 60c.

*SAGE. Leaves and tops used for seasoning and dressing. Pkt., 10c; 3 pkts., 25c; oz., 50c; 1/4 lb., \$1.50.

*SPEARMINT. From the leaves of this plant is distilled the spearmint oil which is used so extensively in the manufacture of chewing gum, etc. The leaves and stems are used for flavoring salads, garnishing meats, etc. No seed. Plants, 20c each; 3 for $40 \mathrm{c} ; 12$ for $\$ 1.00$, postpaid.

SUMMER SAVORY. Leaves and young shoots used for flavoring; especially for boiled string beans. Pkt., 8c; oz, 25c.

*THYME. Leaves and young shoots used for seasoning. A tea is also made from the leaves and used as a remedy for headache. Pkt., 10c; 3 pkts., 25c; oz., 60c.

*WINTERGREEN. A pretty, low growing, evergreen plant with pretty pirk edible berries that are ready to eat before the snow leaves in the spring. Everyone who likes wintergreen flavor is fond of them. These plants will grow on a sour soil that is too poor for almost any other vegetation. No seed to offer. Plants, 20c each; 3 for 40c; 12 for $\$ 1.00$, postpaid.

*WORMWOOD. Leaves used as a tonjc and as a dressing for fresh bruises. Also beneficial for poultry. Pkt., 10c; 3 pkts., 25c; oz., 600.

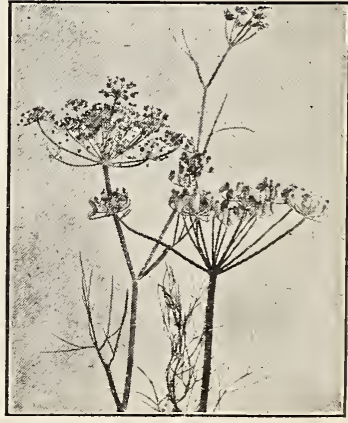

Sweet Fennel 


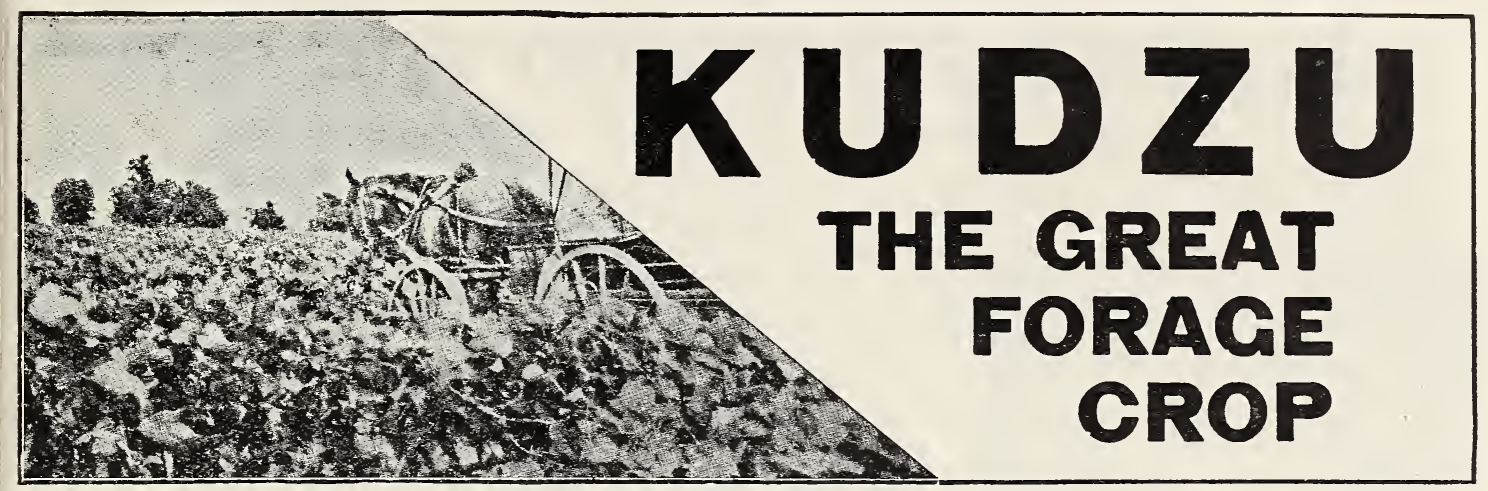

Kurizu gives promise of being one of the leading sources of wealth to farmers and stock growers. It is a wonderful perennial legume, and is perfectly hardy. It outyields alfalfa on poor land; succeeds on land too poor for alfalfa; and does not have to be fertilized or limed. It is adapted to every class of well drained soils, and will succeed on practically any land not water-soaked and not a desert. It enriches poor soil more rapidly and more permanently than it can be improved in any other way, and will transform non-productive, barren hillsides into a main resource of the farm. Poor, worn out land planted to Kudzu soon becomes like the rich soil that has been recently cleared from the virgin forest. The soil becomes richer every year, and the deep roots live to a great age and become stronger and more vigorous as the years pass by. The roots penetrate so deeply as to make it proof against dry weather.

Kudzu contalns more protein than wheat bran-as high as 19.82 per cent and averaging 17.43 per cent. A remarkable feature is that although the hay is richer than alfalfa, yet it is not injurious to horses and is pefectly safe for all stock, when fed either green or dry. Does not cause sickness of animals even when overfed; when fed to cows it will produce more milk and richer milk than any otber one feed; and makes a good permanent pasture.

Kudzu hay does not have to be cut at any certain time to save it, and may await the convenience of the farmer. It cures the quickest of any known hay, and the leaves do not drop off. It can be harvested when weather conditions are unfavorable for other hays and will yield a fine quality of hay, often when continued showers and dampness would mean ruin to any other legume hay. Kudzu hay becomes almost like fresh foliage again when moistened, and makes an excellent green ration for poultry, rabbits and all kinds of stock, in the winter.

Kudzu springs up from the roots when the first warm days come in the spring and grows vigorously until a killing freeze comes in the fall. Two cuttings can be made each year in the North and four in the South. Instances are known where four cuttings of hay averaging $2 \frac{1 / 2}{2}$ tons per cutting and making a total yield of ten tons per acre in a single season, have been made.

Kudzu should be given cultivation the first season. A full crop of corn or a good crop of potatoes, or any other similar crop, may be raised on the same land the first year, so the farmer does not lose the use of the land. After the first year no cultivation is needed, as the vines will run all over the ground the next season and take root at the joints, growing so rapidly as to choke out all other plants (even such pests as Johnson and Bermuda grasses), yet it is an easy matter to get rid of Kudzu if desired, for it has a peculiar habit of neither blooming or bearing seed under field culture, and the plants will only sprout from the crowns and can be killed by cutting off these crowns with a disk plow in hot, dry weather. When the crowns of Kudzu roots are cut off and exposed to sunshine for half a day or so they are killed, and the roots decay. Another method of eradicating Kudzu in case one desires to put a field back to intertilled crops, is to plow late in the fall, and plant the following spring to corn, beans, potatoes or any crop that can be given careful cultivation. While Kudzu is hardier and will stand more severe winters than ordinary alfalfa, and more abuse than most any other plant we know of, it is much more easily eradicated than alfalfa if one wants to get rid of it. Kudzu absolutely can not become a weed pest.

Kudzu is a natlve of Japan, where it is a leading hay crop. - So far as we have been able to learn, it has given the best of satisfaction wherever tried. One farmer who has given it a good trial says: "In my thirty-five years experience in farming in different states, and with various hay crops, I have never seen a hay that cured so quickly, held its leaves so well, or kept its color so perfectly under various conditions as Kudzu does. It does not require lime, as is the case with alfalfa and some other legumes. It does not require a rich soil, and so far as our experiments have gone the past ten years, fertllizing is not only unnecessary but unprofitable. I have had plantings in whlch some were located in the very poorest of soils-soils that would not produce corn, melons, or even cow peas-and with the exception that young plants did not start off quite so readily on these poor spots, no one could tell the difference at the end of the second season."

Growers are now propagarting it almost entirely by transplanting young plants from old Kudzu fields. They prepare the ground the same as for a crop of corn, and then check off into rows 10 feet apart each way, setting a plant at each check. While it is a common, everyday matter for a man to set out a number of acres of cabbage, tomato, tobacco or sweet potatoes, setting each plant by hand, it is rather a shock at first to consider putting out a hay or pasture field in this manner. When we come to scrutinize this objection, however, it seems to vanish in thin air, for the common practice of setting the plants ten feet apart calls for only about 450 plants to the acre. This is a job not nearly so expensive as seeding an acre of alfalfa; especially is this so when we take into consideration the thorough preparation necessary for alfalfa and the cost of liming and manuring or fertilizing the field as is the common practice.

We have a limited supply of seed to offer this season. All Kudzu seed sold by us is put up in sealed packages and guaranteed to be the best that can be produced. more than 80 packages to a person, as we haven't enough to go around.

Inoculation If you plant Kudzu seed it should be inoculated, for best results. We can supply you with enough less), for only $25 \mathrm{c}$

\section{A Satisfied Customer from Ohio Under date of October 5th, S. S. Petry, West Union, Ohio, vine. My Tomatoes are the best and excel all others for size. My Vine Peaches bore all summer and still some on each vine."}




\section{FLOWER SEEDS AND PLANTS}

\section{Annuals - Biennials -- Perennials - House Plants}

Flowers are enjoyed by everyone and are so easily raised that any home can have an abundance of blossoms during the entire year. The seeds we offer are the products of the best growers. No better strains are to be obtained at any price. All perennial plants sent out by us are strong, thrifty, field grown stock, and sure to give satisfaction.

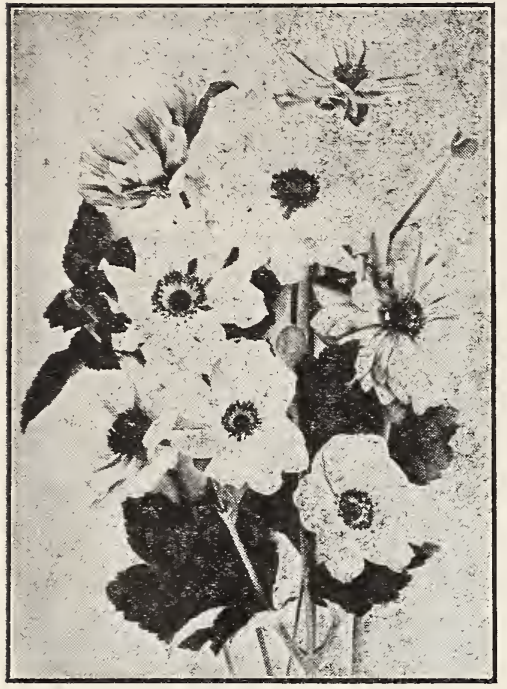

Anemone

ALYSSUM, Little Gem (A). Makes a perfect "carpet of snow," commencing to bloom in spring when very small, and continuing without interruption until late fall. 4 inehes. Pkt., 8c.

Lilac Queen (A). Deep lavenderlilac; dwarf, compact habit. Pkt., 10c.

Sweet (A). Of trailing habit; flowers white; very sweet. Pkt., 5c.

Gold Dust (Saxatile) (P). Deep, pure yellow flowers. Excellent for rockwork and edge of perennial border. Pkt., 10c.

AMARANTHUS, Clandatus_(Love Lies Bleeding) (A). Blood red; drooping 3 feet. Pkt., 5c.

Cruentus (Prince's Feather) (A). Dark red, feathery heads, drooping like a large ostrich plume. Pkt., 8c.

Trico'or (Joseph's Coat) (A). Beautiful plant, growing 3 to 5 feet high, with ornamental leaves variegated in red, yellow and green. The large attractive flower-heads are bright crimson. Pkt., 10c.

Mixed. Many kinds mixed. Pkt., 5c.

ANCHUSA, Italica (Dropmore) (P). Beautiful plant producing spikes of gentian-blue flowers in abundance. 3 to 5 feet. May and June. Pkt., 10c. Plants 300 each.

ANEMONE (Windflower) (P). Large flowers; few plants compare with them in beauty. Pkt., 10c.

ANTHEMIS (Hardy Marguerite), Kelwayii (P). Beautiful daisy-like flowers of clear yellow, in bloom all summer; excellent for cutting. Pretty foliage.
Pkt., 10c. Plants 30e each.

ANTIRRHINUM (Snapdragon). The richness and diversity of their colors and their great freedom and protracted blooming season give them great value as bedding plants, as well as for cutting. Half hardy perennial, treated as an annual in the Northern States. We can supply the following Giant Flowered varieties: Snowflake, white; Apple Blossom, pink and white; Defiance, fiery scarlet; Purple King, rich purple; Golden Queen, clear yellow; Butterfly, beautifully striped. Pkt., 10c; all 6 pkts. for $40 \mathrm{c}$

Large Flowered Mixed. A fine mixture of colors. Pkt., 10c.

Semi-Dwarf Mixed. Fine mixture; good sized flowers. Pkt., 10c.

AQUULGIA (Columbine). Early Hybrids (P). A fine assortment of colors of the earliest flowering varieties. Pkt., 10c. Plants 30c each.
Long Spurred Hybrids (Mrs. Scott Elliott's Strain) (P). A wonderful Long spurred Hybrids (Mrs. Scott Elliott's Strain) (P). A wonderful
mixture containing all the beautiful tints, tones and color combinations for which this strain is famous, hardly two being exactly alike. This is unquestionably the finest strain of Columbine yet produced. The plants are of strong, thrifty growth with flowers of largest size. Pkt., 15c.

ARABIS, Alpina (Rock Cress) (P). One of the earliest and prettiest spring flowers, covered with a sheet of pure white flowers as soon as the snow disappears. Useful for rockeries or edging. 6 to 8 inches. Pkt., 10c. Plants $30 \mathrm{c}$ each.

ARCTOTIS, Grandis (A). Bushy plants, 2 to 3 feet across, with silvery-white, deeply cut foliage. Daisy-like silvery-
hite flowers with blue eyes surrounded by a narrow yellow zone; under part of petals lilac-blue; flowers $21 / 2$ inches white flowers with blue eyes surrounded by a narrow yellow zone; under part of petals lilac-blue; flowers $21 / 2$ inches across. Blooms from early July until frost. Fine for cutting, blooms lasting a week or ten days in water. Plit. 10c.
ASPARAGUS FERN, Plumosus Nanus (H). A graceful pot plant with very finely divided leaves. The finest of the Asparagus Ferns. Pkt., 25c. Plants, 30c each.

Sprengeri (Emerald Feather) (H). A variety of Asparagus Fern with long, drooping branches. Fine for suspended baskets, window boxes, etc. Pkt., 10c. Plants 25c each. 


\section{Giant Ostrich Feather Asters}

We are now offering our improved strain of Giant Ostrich Feather and nsider it the finest of all Asters. The plants are about $2 \frac{1 / 2}{2}$ feet high, robust in growth and branch freely and are loaded with magnificent feathery, full, fluffy flowers of large size. Borne on long stems, they make cut flowers par excellence. We offer the following colors: Crimson, Brilliant Rose, Pink, Light Blue, Dark Blue, Pale Yellow, White Changing into Sky Blue, Pure White. Separate colors or mixed, 10c per packet; 3 pkts., 25c; 8 pkts., 60c.

\section{Queen of the Market Asters}

Our early strain of Queen of the Market Asters is a most valuable type for bedding as well as cutting, as they are the first to come into bloom, and continue blooming until checked by fall frosts. Plants are 15 to 18 inches in height and branch freely near the ground, giving long stems to the flowers. We che sue, Purple, Rose, Scarlet. Separate colors or mixed, 10e Crimson, Light Blue, Purple, Rose,
per packet; 3 pkts., 25c; 7 pkts., 50c.

\section{King Asters}

In form the flower is entirely distinct from any other variety. The blossoms are round, full, and very large; long, narrow, quilled petals, those in the center being curled and incurved, completely covering the crown. CrimPonk, Rose, Lavender, Violet, White. Separate colors or mixed, 10c per packet; 3 pkts., 25c; 6 pkts., 45c.

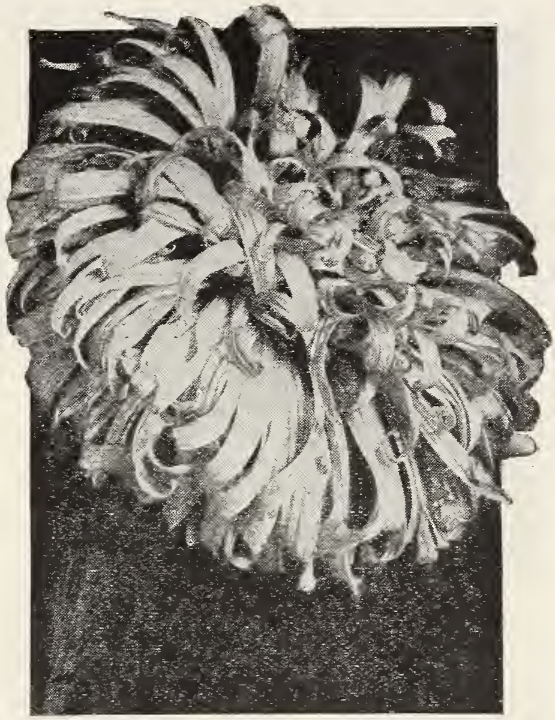

Giant Ostrich Feather Aster

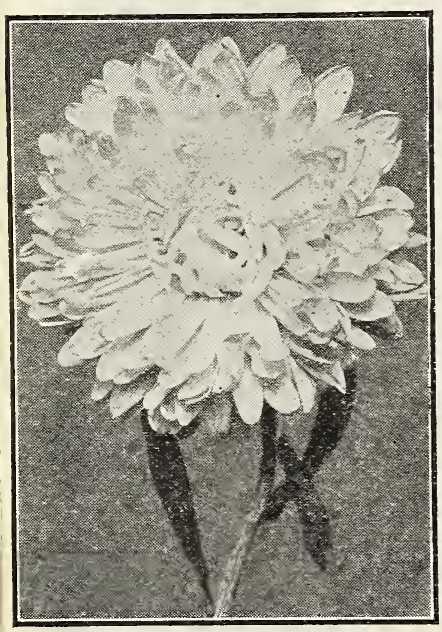

Queen of the Market
Giant Chrysanthemum-Flowered Comet Asters

Our select strain of the Chrysanthemum-Flowered Comet Aster is larger and finer than the much advertised Astermum. Flowers 4 to 6 inches in diameter, very double; long, curled, twisted petals, resembling fine Japanese Chrysanthemums. Flesh-Pink, Rose, Crimson, Sulphur-Yellow, Light Blue, Dark Blue, White. Separate colors or mixed, 10c per packet; 3 pkts., 25e; 7 pkts., 50c.

QUEEN OF SPAIN. A beautiful Aster of the Chrysanthemum Flowered type. A pleasing cream color, changing to flesh. Pkt., 10c.

THE BRIDE. Another fine Chrysanthemum-Flowered Aster. White, changing to rose. Pkt., 10c.

TRIUMPH OF PARIS. White, with large quilled yellow center. Pkt., 10c.

\section{American or Late Branching Asters}

A grand strain of American origin. Plants form strong, branching bushes 2 to $21 / 2$ feet in height, bearing on long, strong stems, flowers which are very double and, under ordinary cultivation, average 5 inches across. Crimson, Scarlet, Bright Rose, Peach Blossom, Flesh, Sky Blue, Purple, Light Yellow, White. Separate colors or mixed, 10 e per packet; 3 pkts., 25c; 9 pkts., 65c.

ANEMONE-FLOWERED GOLDEN-YELLOW ASTER. One of the most attractive novelties. Pkt., 10c; 3 pkts., 25c.

PEONY-FLOWERED PERFECTION ASTERS. Very large and double. A choice mixture of all colors. Pkt., 10c.

YELLOW ASTERS We have prepared a mixture of the new and yellow Asters ever offered. Pkt., 15c; 2 pkts., 25c.

\section{Special All Seasons' Aster Offer}

One packet each of mixed colors of Giant Ostrich Feather, Queen of the Market, King, Giant Chrysanthemum-Flowered. Comet and American Branching-all 5 packets for only 35c.

One packet each of the above named five varieties and a packet each of Queen of Spain, The Bride, Triumph of Paris, Peony-Flowered Perfection and Anemone-Flowered Golden-Yellow-all 10 packets for only 75c.

PERENNIAL ASTERS We have no Perennial Aster seed PERENNIAL ASTERS to offer, but can supply the hardy field grown plants in separate colors-blue, pink, white-at 35c each; 3 for $\$ 1.00$, pestpaid.

BALLOON VINE (A). Rapid and graceful climber; six feet high. Flowers resembling small balloons. Pkt., 5c.

BALSAM (Lady Slipper), Choice Double (A). Finest mixture of beautiful colors. Pkt., 5c.

BALSAM APPLE (Momordica Balsamina) (A). Very curious climbing vine, with very fine glossy green ornamental foliage; fruit golden-yellow, warted, and when ripe opens, showing the seed and its brilliant carmine interior. Fine for trellis, rockwork, stumps, etc. 10 feet. Pkt., 10c.

BALSAM PEAR (Momordica Charantia) (A). Pear-shaped fruit; foliage heavier than the above. The fruits of this variety are used medicinally, and also used extensively in China as a food for human consumption. Pkt., 10c.

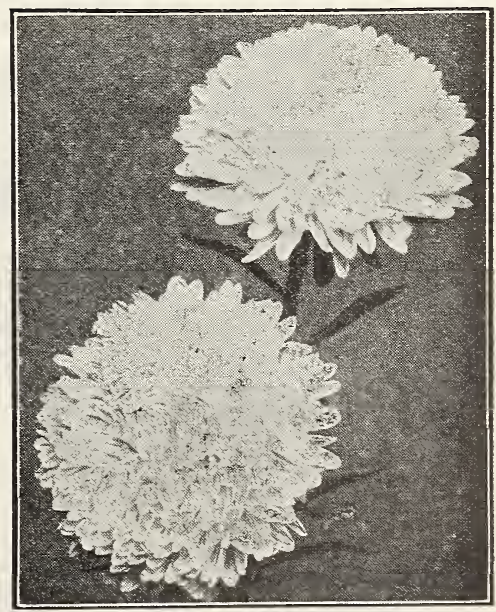

American or Late Branching 


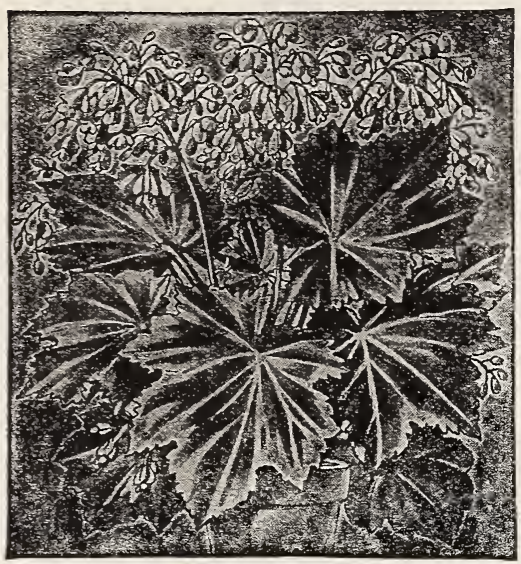

Venus Begonia

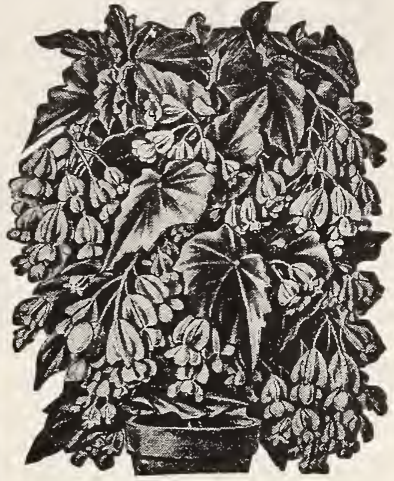

Begonia Argentia Guttata

\section{Begonias}

ARGENTIA GUTTATA (Tree Begonia) (H). Grows 3 to 4 feet tall. Purplebronze leaves with silver markings; white flowers. Plants 35e each; larger plants, 60c.

BEEFSTEAK (Feastii) (H). A low spreading Begonia, with circular leaves, red beneath and dark glossy green above, and of heavy texture. Dainty coral-red flowers. The finest pot Begonia for house culture. Grown as easily as a Geranium. Plants 35e each; larger plants, 50c.

CHRISTMAS RED ( $H)$. One of the best flowering Begonias. The flowers ar bright cherry color, changing to coral-red. Foliage rich, glossy green, shaded deep bronze. The popularity of this Begonia is well deserved from the fact that it is easily grown and very satisfactory both as a winter house plant and for bedding purposes. Plants 30c each.

REX (Giant Painted Leaf) (H). Few house plants are so entirely satiscactory in every way as the Rex Begonias. They are rich in color and beauiful in design and are easily handled under almost any condition. The large, broad leaves, high colorings and exquisite markings make them invaluable as decorative plants for house culture. They make excellent plants for baskets and vases if given plenty of moisture and not exposed to the full rays of the sun. Plants 45c each.

VENUS $(H)$. A new begonia, distinctly different. Its dark, glossy green, deeply cut leaves combined with its free flowering habit, make it one of the most attractive plants grown. Blooms the year around. Plants 40c each; larger plants 75c.

WATERMELON $(H)$. An excellent house plant for the window or table. The leaves withstand the dry air of rooms better than the majority of plants. Leaves thick and waxy-like, are distinctly variegated white and green, and have the appearance of being powdered with frosted silver. Plants 35e each; larger plants 60c.

\section{Begonia Seed}

SEMPERFLORENS HYBRIDS $(H)$. As a bedding plant, it ranks with Coleus and Geraniums. Of sturdy growth, about one foot high, forming dense bushes, which from May until frost, are completely hidden with flowers. As a house plant, it blooms throughout the entire year. A fine mixture of colors, from pure white to deepest crimson. Pkt., 10c.

VERNON $(H)$. Bright orange-carmine flowers; deep red foliage. A fine house plant and unsurpassed as a bedding variety. Pkt., 10e.

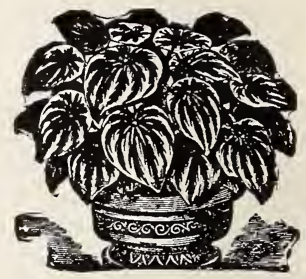

Watermelon Begonia

\section{BELLIS (Double English Daisy)}

A favorite perennial which will stand the winter if given the protection of a little litter. In bloom from early spring until well on in the summer. Fine for borders.

LONGFELLOW (P). Double pink. Pkt., 10c. Plants 30c each.

SNoWBALL (P). Double White. Pkt., 10c. Plants 30c each.

DOUBLE MIXED (P). Fine mixture of red, pink and white. Pkt., 10c.

MONSTROSA GIANT (P). Not so free flowering as smaller flowered varieties, but the flowers are of enormous size, almost as large as a good-sized Aster. Fine mixture of colors. Pkt., 15c.

\section{Blue Lace Flower}

The Blue Lace Flower (Didiscus Coruleus) is a beautiful Australian annual which is becoming very popular on account of its soft blue color, graceful form and beautiful lace-like flowers. The Blue Lace Flower grows into an upright, very much branched plant of about 2 feet in height. Each branch ends in an umbel of light sky-blue flowers which spread out in an umbrella-like fashion, crowning each shoot with a beautiful and delicate head of flowers. The name Blue Lace Flower is most appropriate since the blossoms resemble the

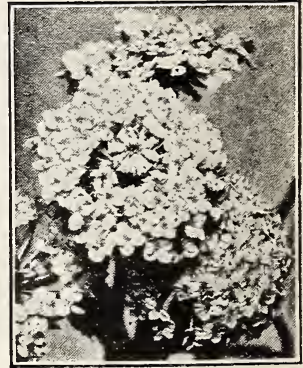

Blue Lace Flower

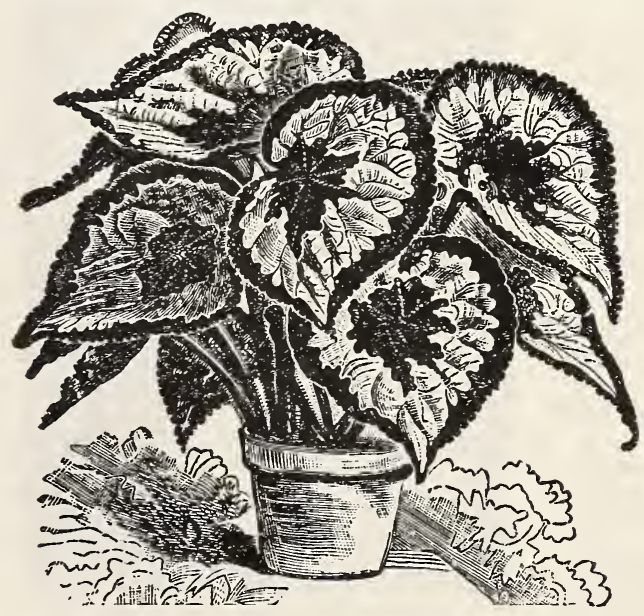

Rex Begonia

most delicate and dainty lace. The many large flower clusters are composed of a great mass of florets on long graceful stems, are unsurpassed for cut flowers and last unusually long in water. It is very easily grown, blooms freely in the garden from July to October, or until the first hard frost. Pkt., 10c; 3 pkts., 25e.

BARTONIA, Aurea (A). Very showy; beautiful yellow blossoms; gray foliage that is exceedingly brilliant in the sunshine. Pkt., 5e.

BOCCONIA, Cordata. (Plume Poppy) (P). A stately plant, 5 to 6 feet high, bearing oanicles of creamy-white flowers, on spikes 2 to 3 feet long. Handsome for shrubbery border or massing. Pkt., 10c. Plants 35e each.

BRACHYCOME (Swan River Daisy) (A). Free-flowering, dwarf-growing plants, about 9 or 10 inches in height; covered during the greater part of the summer with a profusion of pretty blue and white, cineraria-like flowers. Suitable for edgings, small beus and pot culture. Pkt., 10c.

\section{Everything Delivered Prepaid}

All seeds and plants listed in this catalog are delivered prepaid, except where we plainly state otherwise. Therefore, our prices on House Plants, Hardy Perennials, etc., include delivery charges. The prices quoted are just what the seeds and plants will cost you. There will be nothing added for postage, express charges or packing. Remember this when comparing our prices with those charged by some other nursery and seed houses. 


\section{CALENDULA (Pot Marigold)}

One of the best and showiest free flowering hardy annuals. Blooms from early summer until killed by frost; particularly bright in late fall. Valuable also for pot culture, blooming freely in winter and early spring.

METEOR (A). Large double flowers, striped orange and cream. Pkt., 5c.

ORANGE KINO (A). Extra fine, double, rich orange-red variety; flowers over 3 inches in diameter. Pkt., 8c.

\section{PONGEI (A). Double white. Pkt., 8c.}

SULPHUR CROWN (A). Large, double, sulphur yellow. Pkt., 5c.

FINEST MIXED (A). Double sorts mixed. Pkt., 5c.

\section{CALLA}

ELLIOTtaANA (Yellow Calla) (H). Beautiful pure golden yellow flowers, 4 to 5 inches broad. The leaves are attractively marked with white spots. Easily grown. 35c each; 3 for $\mathbf{\$ 1 . 0 0}$.

GLANT GODFREY (Everblooming) $(H)$. The plant is very bushy, having twice as many leaves as the old White Calla and produces three times as many flowers. Flowers are pure white, unusually large, held high, and on stiff stems. 30c each; 3 for 85c.

\section{CALLIOPSIS}

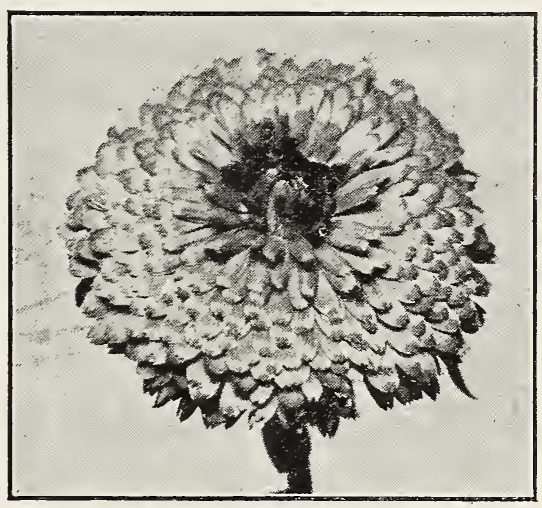

Calendula

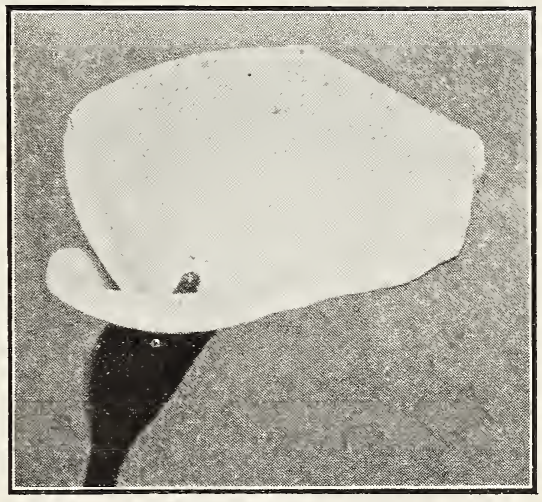

Giant Godfrey Calla

Beautiful, showy, free-flowering plants, of the easiest culture, doing well in any sunny position, blooming all summer and excellent for cutting and massing. By keeping the old flowers picked off the flowering season can be lengthened until late autumn.

CRIMSON KING (A). A fine dwarf sort, 9 inches high; color rich, velvety crimson-garnet. Pkt., 8c.

DWARF MIXED (A). Finest mixture of dwarf varieties; yellow, orange, red, brown, etc. Pkt., 8c.

TALL DOUBLE MIXED (A). Finest mixture of double varieties. Pkt. 8c.

TALL SINGLE MIXED (A). A superb mixture of all colors. Pkt., 5c.

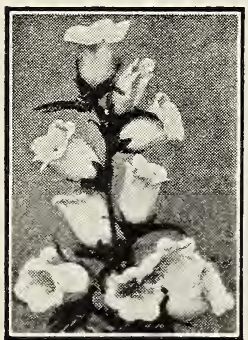

Campanula Medium

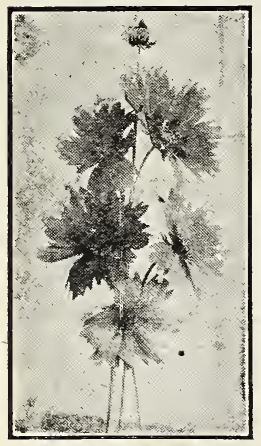

Calliopsis

\section{CAMPANULAS}

(Bellflowers)

CALYCANTHEMA (Cup and Saucer) (B). A fine type of this much prized garden plant. Large, semi-double flowers, each resembling a cup and saucer. Seed in mixture of colors only. Pkt., 10\%. Plants in separate colors-dark blue, light blue, rose and white-30c each; 4 for $\$ 1.00$.

CARPATICA (IIare Bell), B!ue (P). A pretty species growing in compact tufts, not exceeding 8 inches high; flowers clear blue, held erect on wiry stems. It begins blooming in June, continuing until October. As an edging for a hardy border or for the rockery it is unsurpassed. Pkt., 10c. CARPATICA, White (P). A pure white-flowered form of the above. Pkt., 10c.

CARPATICA, Mixed (P). White and blue shades. Plit., 10c.

MEDIUM (Canterbury Bell) (B). The old-fashioned sort with beautiful, large, bell-shaped blossoms. Seed in mixture of colors only. Pkt., 10c. Plants in separate colors-dark blue, light blue, rose and white-30e each; 4 for $\$ \mathbf{1 . 0 0}$.

PERSICIFOLIA (Peach Bells), Blue (P). One of the finest Campanulas, with large, handsome blue, bell-shaped flowers. 2 to 3 feet high. Pkt., 15c.

PERSICIFOLIA, White (P). A pure white-flowered form of the above. Pkt., 15c.

PERSICIFOLIA, Mixed (P). White and blue shades. Pkt., 15c.

PYRAMIDALIS (Chimney Bellflower), Blue (P). A beautiful stately plant; 4 feet; rich blue saucer-shaped flowers borne on long stems. Pkt., 10c.

PYRAMIDAlis, White (P). The white Chimney Bellflower. Plst., 10c.

PYRAMIDALIS, Mixed (P). White and blue shades. Plit., 10c.

PRIZE MIXTURE. A fine mixture of the perennial Campanulas. Pkt., 10c.

\section{CANARY BIRD VINE}

A beautiful rapid growing annual climber, the charming little canary-yellow blossoms bearing a fancied resemblance to a bird with wings half expanded. The sprays of flowers are very artistic and, when cut, keep in good condition for a week. Pkt., 8c.

\section{CANDYTUFT}

The Candytufts are popular everywhere, and considered indispensable for cutting. Seed sown in April, flowers in June. Successive sowings should be made at intervals. Hardy and easy to grow.

GIANT HYACINTH-FLOWERED (A). The finest of all; immense spikes of large, pure white flowers. Plit., 8c.

CRIMSON (A). Very fine; rich and showy. Pkt., 8c.

PINK $(A)$. One of the finest for edging, bedding and cutting. Pkt., 8c.

WHITE (A). Fine for borders. Pkt., 5c.

ALI COLORS MIXED (A). Pkt., 5c.

PERENNIAL CANDYTUFT (Iberis), Sempervirens (P). A profuse, white-blooming, hardy perennial, coming in flower early in the spring. Much used for cemeteries, rockeries, etc. Pkt., 15c.

CANNA GIANT FLOWERED MIXED. Bloom the first DARK LEAVED SORTS. Finest mixture of the red and bronze-leaved varieties. Pkt., 8c.

\section{Brazilian Plume Plant}

A native of Brazil. It is of the easiest possible culture and seems to do well every where, requiring but little attention. It is a strong, rapid grower, throwing many shoots each of which is tipped with beautiful pink, plume-like flowers. Plants 45c each.

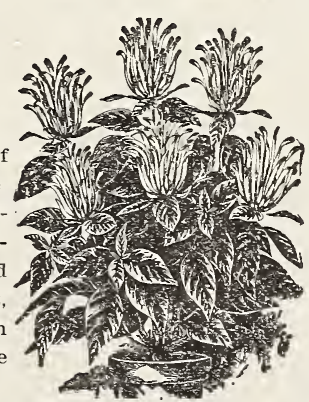




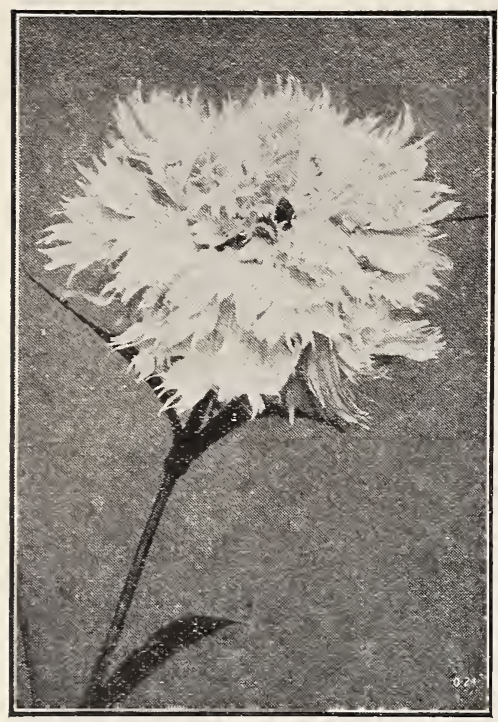

Perpetual Chabaud Carnation

\section{CARDINAL CLIMBER (A)}

The most beautiful and brilliant climber ever grown. Strong, rapid grower, attaining a height of 25 feet, with beautiful fern like foliage and literally covered with a blaze of fiery cardinal-red flowers from midsummer to frost. Pkt., 10c.

\section{CARNATIONS}

MARGARET (A). These are deservedly the most popular Carnations with the amateur, as they begin flowering in four months after seed is sown. Sown early, the plants will bloom during the late summer and early fall, and by repeated sowings they may be had in bloom all winter long if grown in the conservatory or greenhouse. A fine mixture of colors. Pkt., 10c.

PERPETUAL CHABAUD (B). This is a particularly fine strain of giantflowered Carnation which will bloom the first year if seed is sown early in the Spring. The plants make compact bushes 2 to 3 feet tall and bear, on tall stems, a mass of nicely fringed, intensely fragrant double flowers. In many sections of the country they do well outdoors, but it is when grown in the greenhouse that the flowers develop to their best. Choice mixture of colors. Pkt. 10c.

HARDY PERENNIAT (P). The true hardy outdoor Carnation. A beautiful strain which blooms in great abundance all summer. Excellent for cutting and very hardy. Come in separate colors-pink, red, white and yellow. No seed to offer. Plants 35c each; 4 for \$1.25.

\section{CELOSIA}

CHINESE WOOL FLOWER (Celosia Childsii), Crimson (A). One of the most magnificent garden annuals ever introduced. Commences blooming early and continues until frost. 2 to 3 feet high; wool like blossoms in immense clusters, often measuring 2 feet in circumference Pkt.,

Pink (A). A new variety of Chinese Wool Flower, with magnificent glowing pink flowers. Pkt., 15c. 5c.

Mixed (A). A mixture of all three colors of Chinese Wool Flower. Pkt.,

\section{$15 \mathrm{c}$.}

COXCoMb (Celosia Crístata) (A). Free-blooming annuals, growing best in not too rich and in rather light soil. Make grand border plants and are attractive for pots. Fine mixed. Pkt., 8c.

PLUMosA (Plumed or Feathered Celosia) (A). Of pyramidal growth, attaining a height of 3 feet and producing numerous brilliant, massive plumes which resemble ostrich feathers and wave gracefully above the foliage. Choice mixture of red and yellow shades. Pkt., 10c.

\section{CENTAUREA}

CYANUS (Cornflower or Bachelor's Button), Double Mixed (A). A fire mixture of different colors and shades. Pkt., 5c.

GYMNOCARPA (Dusty Miller) (A). Silvery-white, finely cut leaves; used for bedding purposes; beautiful foliage plant for borders and edges. Pkt., 10c.

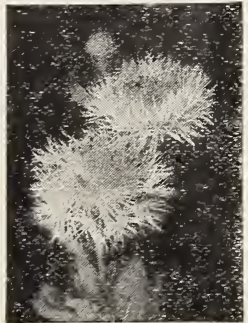

Centaurea Imp.

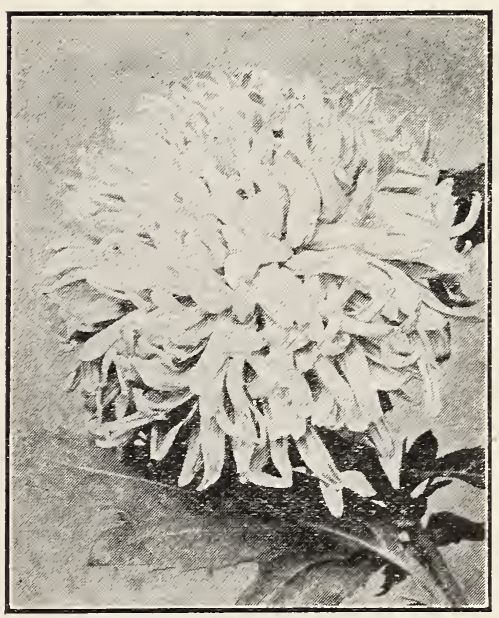

White Turner Chrysanthemum DIPE (Giant Sweet Sultan) (A). The finest of all Centaureas for cut-flower purposes. Beautiful, sweet-scented, artistic-shaped flowers; borne on long. strong stems and when cut will last for several days in good condition. Pkt., 8c.

MoNTANA (Perennial Cornflower) (P). Vigorous grower of easy culture; 2 feet high; large violetblue fiowers from July to September; excellent for

\section{CERASTIUM (Snow in Summer)}

TOMENTOSUM (P). Silvery-white foliage and snow white flowers; hardy perennial; 4 inches in height; suitable for the rockery, "or for carpeting dry, sunny" spots, or covering graves. Pkt., 10c.

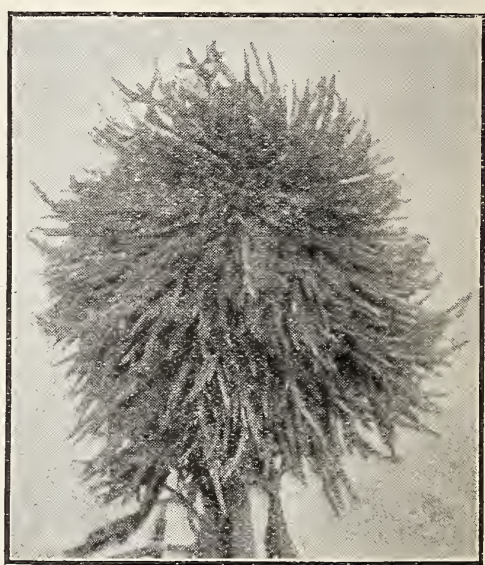

Chinese Wool Flower (Celosia Childsii)

\section{CHINESE LANTERN PLANT}

The Chinese Lantern Plant (Physalis Franchetti) is a hardy, perennial variety of Ornamental Winter Cherry, which is grown for its very attractive balloon-like pods, which turn bright red and resemble Chinese paper lanterns. May be dried for winter decorations, being very fine at Christmas time. Pkt., 10e. Plants 35c each.

\section{EXHIBITION CHRYSANTHEMUMS}

BLACK HAWK (H). Late flowering; dark velvety crimson-scarlet; blooms of immense size and fine form.

CHRYSOLORA (H). A new yellow variety; large, beautiful blooms.

COL. APPLETON $(\mathrm{H})$. One of the most largely grown yellow varieties.

CULLINGFORDII $(\mathrm{H})$. One of the best late flowering varieties; rich crimson, shaded dark red.

MONROVIA ( $\mathrm{H})$. Deep orange color; a massive flower with incurved petals; early cut-flower variety.

PACIFIC SUPREME (H). Bright pink; comes into bloom about the last of August.

POLLY ROSE (H). Early; rose-pink; broad petals.

WHITE CHIEFTAIN (H). Pure white; one of the most valuable commer-

WHITE MISTLETOE (H). Blush-white flowers of exquisite form and finish.

WHITE TURNER $(H)$. A perfect ball of purest white; a wonderful variety. Your choice of the above Exhibition Chrysanthemum plants, 35c each; 3 for $\$ 1.00$, postpaid.

SPECIAL OFFER. Ten Chrysanthemum plants-one each of the above ten varieties-only $\$ \mathbf{2 . 6 0}$, postpaid. 


\section{Hardy Perennial Chrysanthemums}

There is probably nothing else in the outdoor fall-blooming plant line that is so valuable as the Hardy Perennial Chrysanthemum. We have no seed to offer, but can supply plants of all types, kinds and colors, in fine mixture, at $\$ \mathbf{1 . 5 0}$ per half dozen or \$2.50 per doz. We can also furnish the large-flowered varieties in separate colors-red, pink, white, and yellow-at 35c each; 4 for \$1.20.

\section{Annual Chrysanthemums}

DOUBLE WHITE (A). Valuable summer-flowering border and bedding plant, which bears large quantities of blooms which are excellent for cutting, and quite distinct from the autumn flowering varieties. Pkt., 5c.

DOUBLE YELLOW (A). Same as Double White, except the color, which is bright yellow. Pkt., 5c.

DOUBLE MIXED (A). Pkt., 5c.

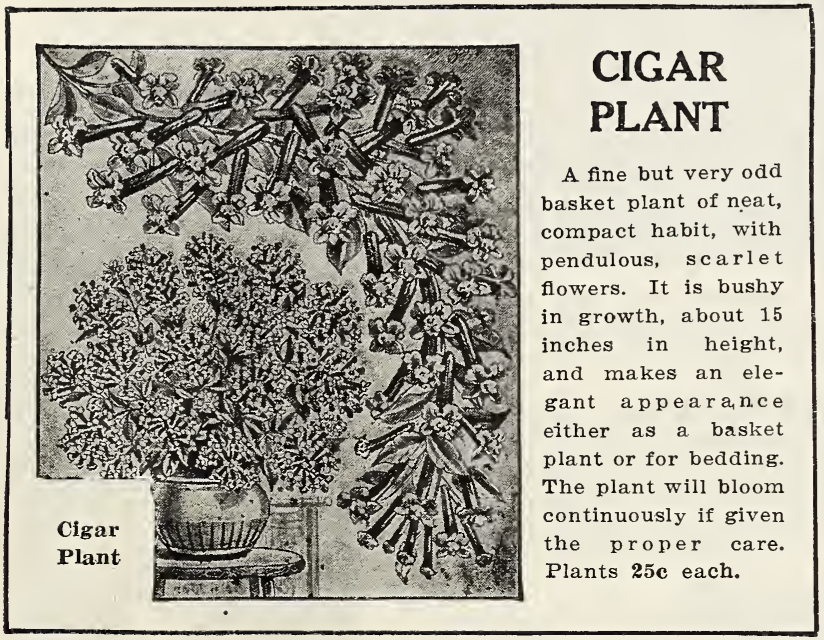

\section{Giant Exhibition Cineraria}

Our Giant Exhibition Strain of Cineraria is unsurpassed in size of flower, bright colors, and delicate fragrance. Plants grow into round bushes, completely covered by the massive flower-heads. For Christmas blooming, seed should be sown in April; for blooming during early spring, June or July sowing should be made. Sow seed in shallow boxes containing a fine, fairly sandy soil. Keep shaded and moist until seedlings appear. Transplant into other boxes as soon as they

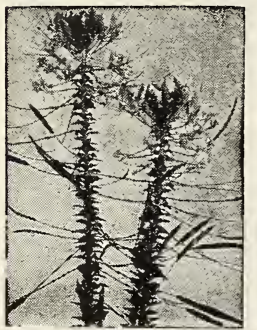

Cleome Pungens are large enough to be handled, and into small pots when the plants attain a fair size. Cinerarias delight in a rich soil, cool and airy rooms and plenty of light. Pkt., 25e; 3 pkts., 60e.

\section{Cleome}

PUNGENS (Giant Spider Plant) (A). A fine plant for large beds and for interspersing in the shrubbery border. 4 to 5 feet high, with showy rose colored flowers of peculiar and interesting shape, suggesting spiders. Plants given sufficient room to develop their full beauty are very striking, and bloom every day in the season. Pkt., 8c.

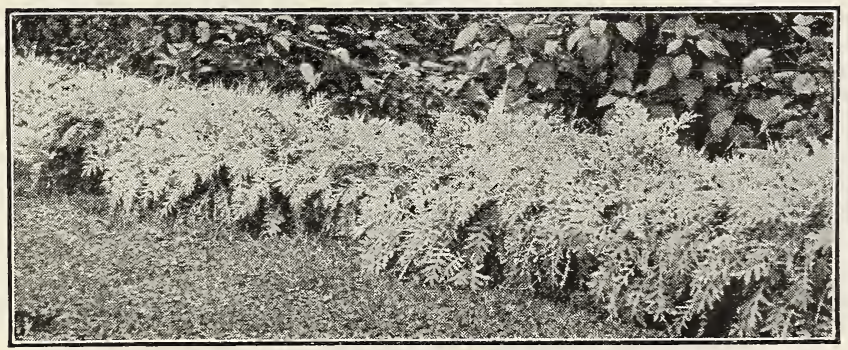

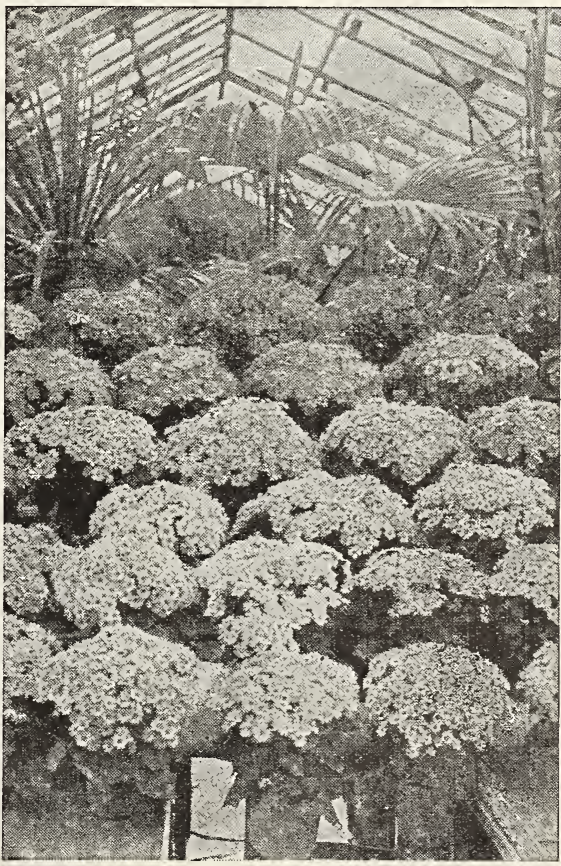

Giant Exhibition Cineraria 


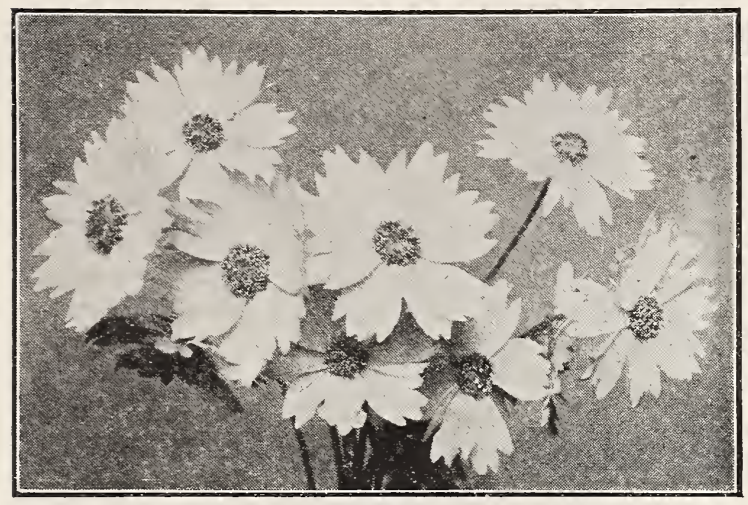

Coreopsis

\section{Coleus}

RAINBOW HYBRIDS (H). The Coleus is the most handsome foliage plant obtained from seed, and our Rainbow Hybrids are very fine, being surpassed only by our LargeLeaved Hybrids. Richly colored, and a most attractive and novel foliage plant for the house and for bedding out. Plit., 10c.

LARGE-IEAVED HYBRIDS (H). Leaves often measure 10 inches in length and 8 inches in width, heart-shaped and beautifully crimped, toothed and frilled; handsomely variegated and with color combinations that are remarkably rich. The finest strain of Coleus seed ever offered. Pkt., 25c.

TRAILING QUEEN (H). The most attractive and satisfactory Coleus for hanging baskets, vases, plant boxes, etc., on account of its trailing habit. Center of leaves fiery crimson surrounded with deep maroon; deeply serrated edges of bright olive green. No seed. Plants 25e each; larger size, 40c each.

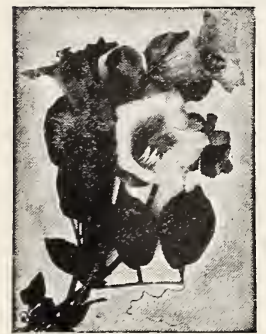

Cobea Scandens

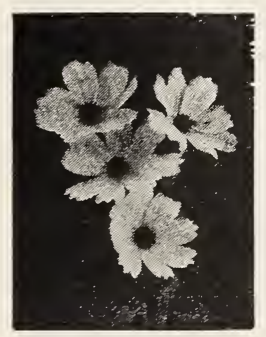

Cosmos

\section{Comet Plant}

The Comet Plant (Acalypha Sanderii) is a most desirable addition to any collection of house plants. From the axil of each of the attractive dark green leaves springs a long, drooping spike of glowing crimson-scarlet, nearly an inch in diameter and from 18 to 24 inches long, very velvety in texture, reminding one of a very long piece of brilliant chenille. Plants 30c each.

\section{Coreopsis}

LANCEOLATA GRANDIFLORA (P). This is one of the finest hardy plants, with large, showy bright yellow flowers, produced in greatest abundance from June until frost. As a cut flower they stand near the head of the list of perennials, having long stems and lasting in good condition a week or more. Pkt., 5e. Plants 25e each; 6 for $\$ 1.00$.

\section{Cosmos}

Beautiful summer and autumn blooming plants, producing thousands of artistic flowers and fủrnishing an abundance of cut blossoms for autumn decorations when other flowers are scarce. AUTUMN GIANTS (A). Gigantic flowers with broad, overlapped petals of splendid substance; borne on very long stems. All colors mixed. Pkt., 5c.

GIANT SUMMER, Crimson (A). As early as the earliest and continues until frost. Nearly as large as the late sorts. Pkt., 8c.

GIANT SUMMER, Pink (A). A beautiful rosy-pink flowered form of the above. Pkt., 8c.

GIANT SUMMER, White (A). Pure white. Pkt., 8c.

GIANT SUMMER, Mixed (A). All three colors, mixed. Pkt., 8c.

EARLY-FLOWERED DOUBLE, Crimson (A). For picture and description of our double Cosmos, see front cover of this catalog. Pkt., 20c; 3 pkts., 50c.

EARLY-FLOWERED DOUBLE, Pink (A). Pkt., 20c; 3 pkts., 50c.

EARLY-FLOWERED DOUBLE, White (A). Pkt., 20c; 3 plsts., 50c.

EARLY-FLOWERED DOUBLE, Mixed (A). Pkt., 25c.

\section{Cypress Vine}

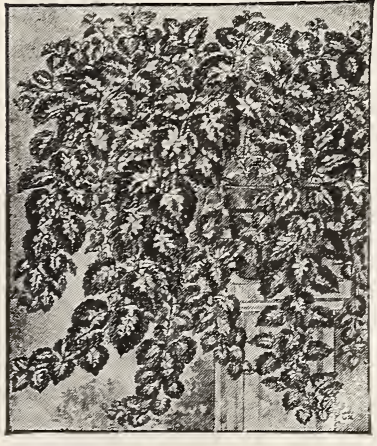

Coleus Trailing Queen

One of the most popular climbers. Very delicate fern-like foliage, and masses of small bright star-shaped flowers.

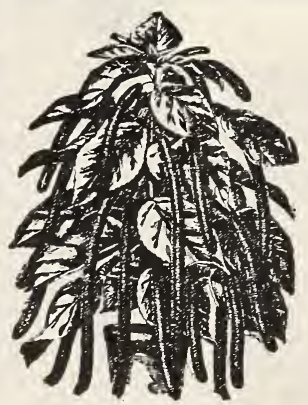

Comet Plant
Scarlet (A), Pkt., 5c. Mixed (A). Scarlet and white. Pkt., 5c.

\section{Crown of Thorns}

(Euphorbia Splendens $(\mathrm{H})$. A curious plant, with thick, fleshy, twining stems which are covered with spines nearly an inch in length. The foliage is bright green and flowers are a beautiful coral pink. Plants 30c each.

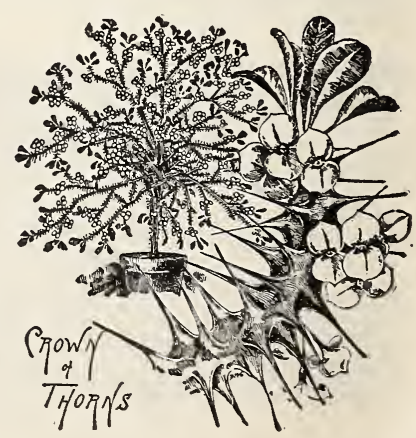




\section{Cyclamens}

Cyclamens are, without question, one of the best and most beautiful house plants. Our Cyclamen seed is grown for us by a specialist, seed being selected only from plants of superior bloom and foliage. The flowers are unsurpassed for size, color and substance. The seed we offer is a mixture of bright red, dark red, light pink, deep pink, salmon, white, white with carmine eye, etc. In fact, the colors range from white to darkest crimson, with all intermediate shades. Seed should be sown in shallow pans containing a mixture of finely sifted soil and leaf-mold. Keep warm and moist until the seeds sprout, which usually takes four weeks. When the plants are large enough to handle, they should be transplanted into small pots to be repotted into larger ones as the plants increase in size.

Prize Mixture of Giants $(\mathrm{H})$. Extra large and choice. Pkt., (10 seeds) 20c; 3 plits., 50c; 10 pkts., \$1.50.

Good Mixture $(\mathrm{H})$. A very fine strain, but not as large as our Prize Mixture of Giants. Pkt., (10 seeds) 15c; 2 pkts, 25c; 10 pkts., $\$ 1.00$.

DAHLIAS As easily grown from will bloom the first year if seed is sown early.

CHOICF DOUBLE. Show, Decorative and Peony-Flowered; all double varieties and colors mixed. Pkt., 15c.

DOUBLE CACTUS-FLOWERED. Excellent mixture of the finest Cactus sorts. Pkt., 20c.

SINGLE MIXED. All colors. Pkt., 8c.

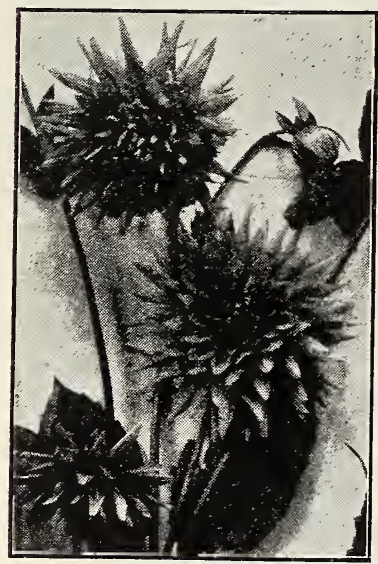

Cactus Dahlias

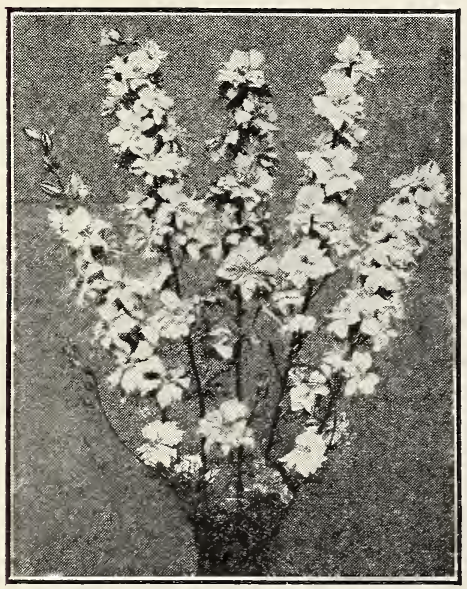

Gold Medal Hybrid Delphiniums

\section{DELPHINIUM (Hardy Perennial Larkspur)}

The Delphinium is, beyond question, the Queen of all blue flowers. Their wonderful stateliness, loose, graceful shape of flowers, and fine colors make them suitable for most any floral work; very effective in borders and planted among the shrubbery; and as cut flowers they have few equals.

BELLA DONNA (Everblooming Hardy Larkspur) (P). The most continuous and free blooming Delphinium. The clear turquoise blue of its flowers is unsurpassed for delicacy and beauty. 3 to 4 feet. Pkt., 20c. Plants 30c each; 3 for 85̃.

CHINESE, Large-Flowered Blue (P). A very pretty variety with fine feathery foliage and intense gentian-blue flowers in open panicles. $2 \frac{1}{2}$ to 3 feet. Pkt., 10c. Plants 300 each; 3 for 85 c.

CHINESE, Large-Flowered White (P). A pure white form of above. Pkt., 10c. Plants 30e each: 3 for 850 .

CHINESE, Large-Flowered Mixed (P). Blue and White. Pkt., 10c.

FORMOSUM (P). Rich, dark blue with white eye; immense flower-spikes 3 to 4 feet in length. Pkt., 20c.

GOLD MEDAL HYBRIDS $\left(P^{\prime}\right)$. This is unquestionably the best and finest to be secured anywhere. The range of color varies from the palest shade of blue to the deepest indigo-blue and royal purple with many intermediary pastel tones of mauve, pink, and lavender blendings. Among these new hybrids are flowers of huge size, in both single and double forms. This strain has been raised from seed saved from the finest named kinds. Those who wish to perfect their already prized borders cannot afford to overlook these wonderful hybrids. Pkt., 20c; 3 pkts., 50c. Plants 30c each; 3 for $85 \mathbf{c}$.

YELLOW DELPHINIUM (P). A rare and wonderful hardy variety. Long spikes, 2 to 3 feet in length, set closely with bright yellow flowers. A few of these mixed in with the blue varieties is very effective. Pkt., 250.

\section{DIGITALIS (Foxglove)}

One of the most popular and highly ornamental hardy plants. Succeeds under almost all conditions and with but little attention will give a wealth of flowers during July and August.

GIANT SHIRLEY (P). A magnificent strain, with enormous spikes, 5 to 7 feet in height and flower-heads over 3 feet long. Colors range from white and shell-pink to deepest rose, and attractively spotted with crimson-maroon and chocolate. Mixed colors only. Pkt., 15c. Plants 35c each; 3 for \$1.00.

GLOXINIAEFLORA (P). A fine strain of the ordinary Foxglove, with handsome spotted Gloxinia-like flowers on long spikes. 2 to 4 feet. Seed in mixture of colors only. Plkt., 10c. Plants in separate colors-purple, rose, white-35c each; 3 for \$1.00; mixed colors 25c each.

GRANDIFLORA (P). A beautiful clear yellow variety. No seed to offer. Plants 35e each; 3 for $\$ \mathbf{1 . 0 0}$.

\section{DIMORPHOTHECA}

\section{(AFRICAN DAISY)}

AURANTICA HYBRIDS (A). Bushy plants, 12 to 15 inches high; flowers $2 \frac{1}{2}$ inches and over across. Splendid mixture of all colors from white through various shades of cream, yellow, orange, rose, etc., and many flowers being zoned with several of these colors around darker colored centers. Pkt., 10c.

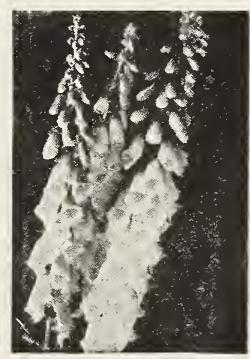

Digitalis 


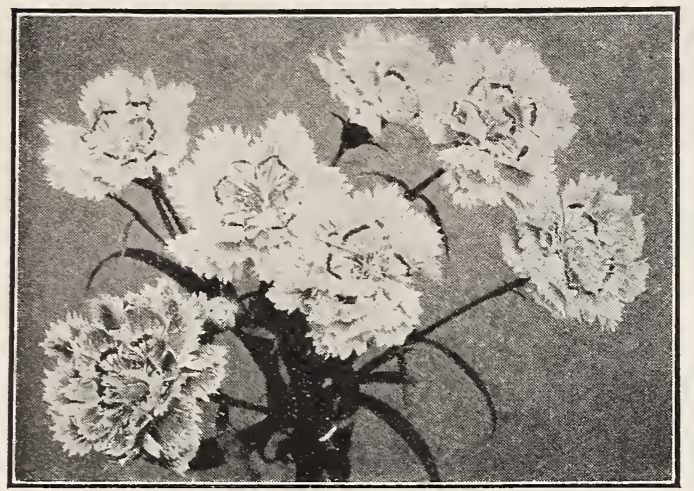

Double Dianthus Plumarius

\section{Dianthus or Pinks}

Few flowers can equal the old-fashioned Pinks in beauty and profusion of blooms. They are easily grown and do well in almost any kind of soil and location. The biennial varieties are usually treated as annuals, and are a mass of bloom within a few weeks after seed is planted. As a rule, they survive the winter if given slight protection, flowering abundantly the following season.

CHINESE, Double (B). Sometimes called Indian Pinks. Handsome clusters of very double flowers; many bright colors. Pkt., 5c.

FIREBALL (B). Large, double; rich, blood-red; splendid for cutting or as a border. Pkt., 10c.

HEDDEWIGI, Giganteus (Large Flowered Single Japanese Pinks) (B). Flowers 2 to 3 inches in diameter; borne very profusely and make a wonderful show in beds or borders. The range of colors include many shades of pink, rose and also pure white, and many marked with rose and red centers or edges. Pkt., 8c.

HEDDEWIGI, Double (Double Japanese Pinks) (B). A fine mixture of colors, varying from the richest velvety crimson to the most delicate rose. Pkt., 10c.

LACINIATUS. Double Mixed (B). Flowers very large and double and the edges of the petals are exquisitely fringed and laciniated. A fine mixture of brilliant colors-white, pink, rose, red and maroon shades, with white egdes and variegated. Pkt., 10c.

MALMAISON (B). Very large double fringed flowers in very beautiful bright rose tints. Pkt., 10c.

SNOWBALL (B). Large double fringed flowers of pure white. Excellent for cutting. Pkt., 10c.
PLUMARIUS, Double (P). The old favorite Clove or Hardy Garden Pink. Double and semi-double carnation-like flowers, in shades of rose, pink and white. Pkt., 10c.

PLCMAriUS, Single (Grass Pink, Scotch Pink, or Pheasant-eye Pink) (P). A beautiful single hardy Pink, with fringed edged flowers of various colors. Pkt., 8c.

DOLICHOS (Hyacinth Bean), Purple Soudan (A). A rapid growing climber for sunny situations. 8 to 10 feet. Stems purplish-red; red and purple shades in the leaves. Long spikes of pea-like flowers of deep reddish maroon, followed by beautiful metallic purple seed pods. Pkt., 5c.

Princess Helen (A). Pure white flowers; green foliage. Pkt., 5c.
White Bush (A). A bush form of Princess Helen. Magnificent

flower spikes that grow from 10 to 15 inches above foliage. Pkt., 8c.

DRACOCEPHALUM, Moldavicum (Dragon's Head) (A). Showy annual producing long spikes of light blue flowers. Fine for cutting. Pkt., 5c.

\section{ESCHSCHOLTZIA (California Poppy)}

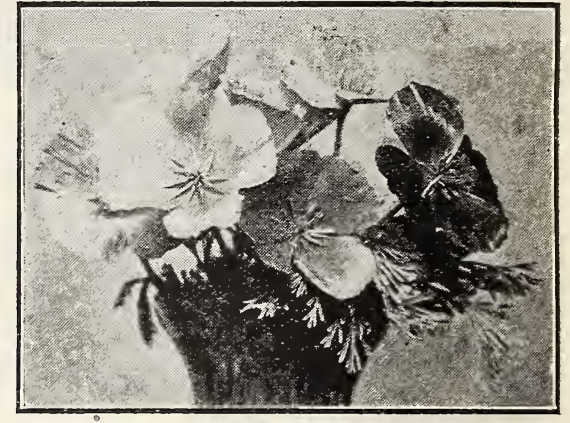

Eschscholtzia (California Poppy)

\section{A beautiful and brilliant annual with finely cut, blue-green foliage,} and glossy flowers of satin-like texture. One of the most desirable annuals for beds and borders and for cut flowers. Seed should be sown where the plants are to remain, as they do not stand transplanting; require practically no care; and in any sunny position, will bloom profusely over a long season.

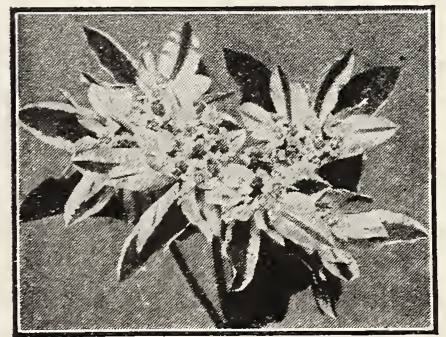

Euphorbia Variegata

CARMINE KING (A). Deep carmine red. A bed of these in bloom appears like mass of bright red Tulips. Pkt., 10c.

LARGE YELLOW (A). Large and beautiful. Pkt., 5c.

ORANGE KING (A). Rich golden orange. Pkt., 5c.

ROSEA (A). Beautiful rosy pink. Pkt., 10e.

ROSE CARDINAL (A). Dark rose on the outside; inside blush. Pkt., 10c.

WHITE (A). Extra Fine. Pkt., 5c.

MLXED (A). A choice mixture of all colors. Pkt., 8c.

\section{Everlasting Flowers}

To meet the growing demand for these for use in winter bouquets we have made up a collection containing a packet each of the best eight varieties. Price, 50c; 3 collections, \$1.25.

ERYNGIUM (Sea Holly), Planum (P). A pretty, bushy plant with thistle-like heads of flowers of a beautiful steel-blue. Very useful for dry bouquets in winter. $2 \frac{1}{2}$ feet. Pkt., 5c. Plants 30c each.

EUPHORBIA, Variegata (Snow on the Mountain) (A). One of the finest foliage plants for outdoor planting. Foliage attractively veined and margined with white. 2 feet. Excellent for beds and borders. Pkt., 8c.

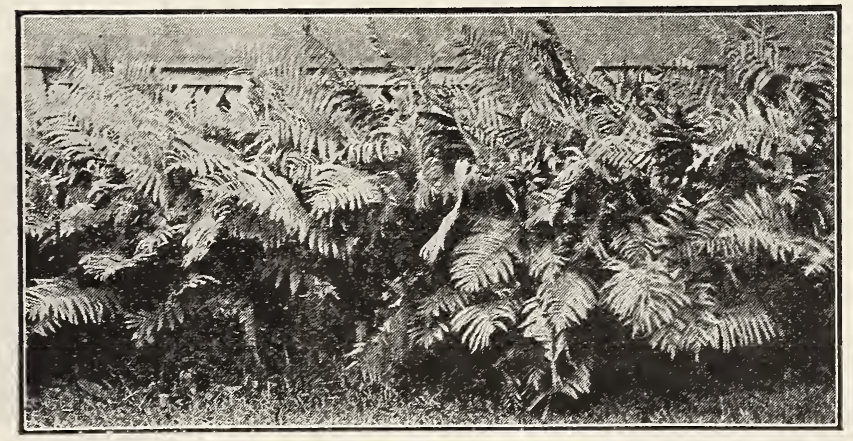

Hardy Ferns (See page 41)

FEVERFEW, Hardy (P). Free-flowering plants, producing all summer, fine double white flowers. Fine for cutting. Pkt., 5c. Plants 30c each.

Eittle Gem (H). A Feverfew that is extensively used by florists for cut flowers during the summer, fall and winter. It is very dwarf, attaining a height of from 12 to 18 inches. Flowers large, pure white, double and of perfect form. No seed. Plants 25c each.

FOUR O'CLOCK (Marvel of Peru) (A). A well known, handsome, free-flowering garden favorite; does well everywhere; 2 feet. Fine mixed colors. Pkt., 5c. 


\section{Ferns}

BostoN (H). The world famous Fern. A wonderfully healthy, rapid growing and graceful plant. Its long drooping fronds often attain a length of 6 to 8 feet. Its unusual freedom of growth without special care has made it popular with all admirers of house plants. Plants 30c each; large plants, 90c.

COMPACTA $(H)$. This new Fern is quite different from all others. Its distinguishing characteristics are its dark green foliage, darker than any other Fern; its dense growth; and its irregular shaped fronds, which are so formed as to resemble miniature Ferns, giving it the appearance of a Fern within a Fern. Plants $\$ 1.00$ each.

MAIUEN HATR (H). An extremely beautiful and healthy dark green, feathery house plant that is very popular. The fronds of this lovely Fern, which are developed at the ends into bunching tassled heads, are much used in cut-flower work. Plants 30c each; larger plants 45c.

OSTRICH PLUME (HI). A new feathery foliage Fern which everyone can succeed in growing. Healthy, vigorous grower, constantly unfolding fresh fronds, which often attain a width of 12 inches. Each frond is delicately and finely cut, possessing such elegance of form and willowy grace as to be compared to a beautiful ostrich plume. Plants 40c each; larger plants, 80c.

ROOSEVELT $(\mathrm{H})$. An ideal Fern and a notable and valuable novelty. Wins prizes everywhere; has had the most phenomenal sale of any decorative plant grown. Fronds broad, 5 to 6 feet long. The divided pinnea or miniature fronds which are so gracefully arranged, keep growing constantly, overlapping each other and showing different shades of green, the contrast producing a beautiful effect. Plants $40 \mathrm{c}$ each; larger plants, 65e.

RUFFLED LAKE $(\mathrm{H})$. A new decorative Fern that is very rugged, yet graceful, drooping, crinkled, ruffled and curled fronds, that never break down, giving the plant a distinctive character and special decorative value. Makes a wonderful display for porch or window garden, and a durable house Fern. Plants 50c each; larger plants 85̃.

TEDDY JUNIOR (H). A superb dwarf form of the Roosevelt Fern. Very popular.e Plants 35e each; larger plants 65e.

\section{HARDY FERNS}

Hardy Ferns do well in shady and half-shady places in the garden and park and are often useful for growing close to houses, in corners which are too dark for most plants. Ferns do best in light soils containing much vegetable matter, so it is always best to work a considerable amount of leaf mould into the soil of a fern bed. The

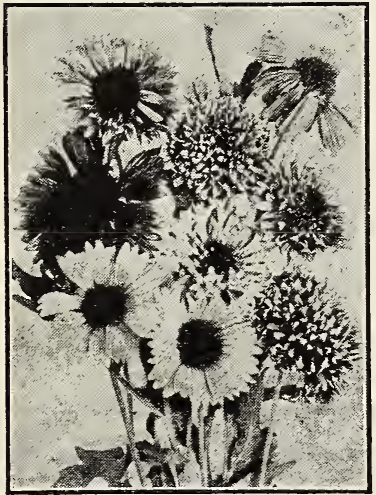

Annual Gaillardia

common notion that Ferns require wet or almost swampy conditions is not well founded, as they will do nicely under ordinary garden treatment in the matter of moisture.

We have a fine assortment of Hardy Perennial Ferns, and sell them in mixture only. 25e each; 3 for 65c; 12 for $\$ 1.75$, postpaid.

\section{FUCHSIAS}

FREE-FLOWERING FUCHSIAS. Your choice of the following varieties at 40c each 3 for $\$ 1.10$.

Phenomenal (H), Bright scarlet flowers with rich purple corolla.

Wave of Life $(\mathrm{H})$ Golden foliage; flowers dark purple.

Glorie Des Marches $(H)$. Double; deep scarlet and white.

Speciosa $(\mathrm{H})$. Flowers four inches or more in length; tube and sepals bright carmine.

Fdmond About (H). Semi-double; white corolla, deep pink petals.

Montrose $(\mathrm{H})$. Extra large, pure white flowers.

Purple Prince (H). Double; sepals scarlet, corolla beautiful distinct blue.

White Giant $(\mathrm{H})$. Tube and sepals reddish crimson; corolla pure white.

SPECDAL OFFER. One each of the above eight Fuchsias for only $\mathbf{\$ 2 . 6 0}$.

FUCHSIA SEED ( $\mathrm{H})$. A fine mixture of varieties. Pkt., 25c.

\section{GAILLARDIA (Blanket Flower)}

Annual. Remarkable for the profusion, size and brilliancy of their flowers, continu ing in bloom from early summer until November. Excellent for beds, borders, or for cutting. A fine range of colors, from creamy-white and yellow shades to orange and crimson, both single and double. A fine mixture. Pkt., 5c.

Perennial. Among the showiest and most effective hardy perennial plants, and should find a place in every hardy border. They thrive in almost any position or soil, and practically take care of themselves. Large flowers of crimson and gold, on long stems; fine for cutting. Pkt., 8c. Plants 25c each.

GEUM, Mrs. Bradshaw (P). Beautiful branching plant, about 2 feet in $h$ ight. bearing profusely throughout the entire summer, large, showy, double flowers of brilliant orange-scarlet. Excellent for cutting. Pist., 10e. Plants 3öe each.

GILIA (A). Very graceful plant, about 2 feet high, with fine feathery foliage. Bear freely over a long season, globular heads about one inch across, of rich blue and white flowers, which last well when cut and retain their lovely color when dried. Pkt., 5c.

GLADIOLUS. Easily grown from seed, and bloom the second year. Seed saved from the mammoth flowered varieties only. A fine mixture of colors. Pkt., 10c.

GLOBE AMARANTH (Gomphrena) (A). Popularly known as the Everlasting Bachelor's Button. Globeshaped flowers that can be dried and used for winter bouquets. Pkt., 8c.

GLOXINIA, Hybrida Grandiflora (H). Magnificent flowers of the richest colors. An unsurpassed strain, containing the spotted hybrids as well as the finest selfcolored sorts. Pkt., 25c.

GODETIA (A). Beautiful, hardy annual about one foot high; blooms profusely; showy flowers of satiny texture, not unlike an Azalea, in many rich and varied colors and 3 to 4 inches across. Not recommended for hot loand 3 to 4 inches across. Not recommend
cations; do best in poor soil. Pkt., 10c.

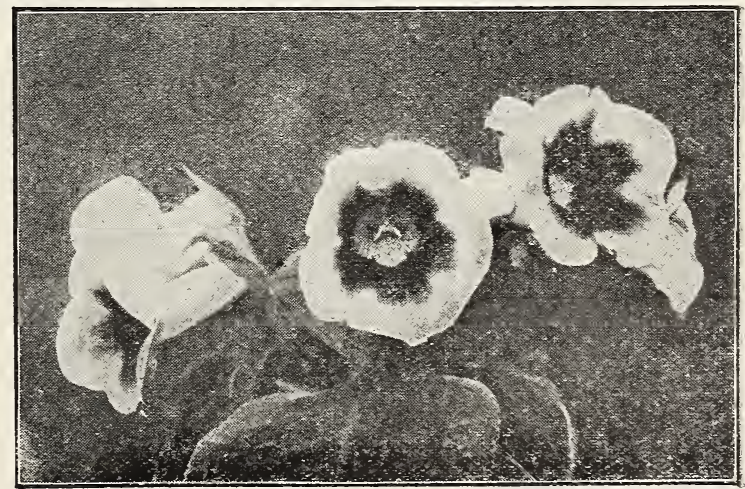

Gloxinia 


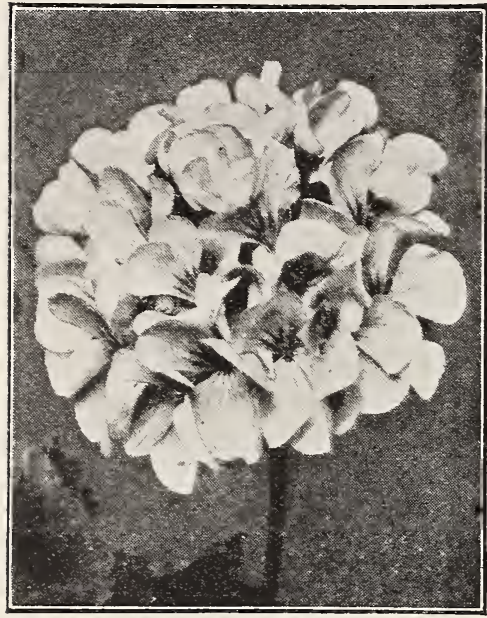

Geranium Mrs. Lawrence

\section{GERANIUMS}

CARDINAL. Dazzling scarlet; always a mass of bloom. 25c each. FIREBALL. Largest and darkest red Geranium grown, 25c each. FRANCES WILLARD. Exquisite shade of pearl pink. 25c each. JEAN VIAND. Rosy pink blooms; giant grower; prolific. 25c each. HA FAvORITE. Bushy plant, covered with white blossoms. 25c each. MRS. LAWRENCE. Satiny salmon-pink. Very dainty. 25c each. SPECIAI-Any 3 of the above Geraniums, 70c; the six for $\$ 1.35$.

\section{Fancy-Leaved Geraniums}

DOUBLE SILVER-LEAVED. In this beautiful Geranium we have the only double-flowered silver-leaved variety. Flowers bright pink; foliage deep green with a margin of pure white. 45c each.

GOLDEN TRI-COLOR. Leaves have bronze zone, belted with crimson and edged golden-yellow; orange-red flowers. 30c each.

HAPPY THOUGHT. Dark green foliage with creamy-white center, bordred bronze. Flowers scarlet, 30c each.

SILVER-LEAVED S. A. NUTT. A most beautiful silver-leaved variety; flowers dark red. 30c each.

\section{Ivy Geraniums}

A splendid class of Climbing or Trailing Geraniums, with leaves resembling those of the Ivy. Especially adapted for baskets, window boxes, vases, training on trellises, etc.

ALLIANCE. A most exquisite shade of delicate lilac-white; upper petals feathered and blotched crimson-rose; semi-double. 35c each.

CAESAR FRANC. Magnificent shade of soft, rich crimson, with an exquisite shading of rose at the base of the petals. 35c each

JOAN OF ARC. New white Ivy Geranium. The flowers are of good size, perfectly double, snow white; an easy growef. 35c each.

P. CROZY. Soft, bright scarlet. 35e each.

RYCROFT'S SURPRISE. A beautiful, rich pink. 35e each.

SPECIAL OFFER. 3 Choice Ivy-Leaved Geraniums-1 red, 1 white, 1 pink-our choice of varieties, 90c.

\section{Pansy Geraniums}

GARDENER'S JOY. Flowers of extraordinary coloring. The ground color is apple blossom pink; the two upper petals have blotches of carbon-brown. The florets are $31 / 2$ inches in diameter and are joined to enormous clusters which rise above the beautiful foliage. $45 \mathrm{c}$ each.

ORIGINAL PANSY GERANIUM. Highly colored and exceedingly attractive flowers, rivaling the Pansy. Light pink, white, dark purple, black, etc.; choice mixture of colors. $45 \mathrm{c}$ each; 3 for $\$ 1.30$.

\section{Sweet Scented Geraniums}

These beautiful and useful Geraniums are extensively grown for their highly fragrant

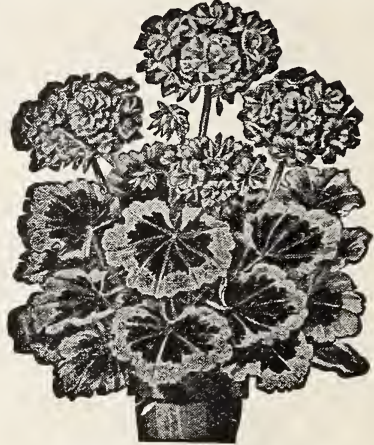

Silver-Leaved Geranium foliage, and to be used among cut flowers which have no perfume of their own, as well as in making toilet waters, flavoring jellies, etc.

BALM. Very fragrant large leaves; flowers light lilac. Very fine.

CUT-LEAF ROSE. Beautiful pink flowers; odd-shaped leaves; a favorite sort for making perfumes.

LADY MARY. Large, pelargonium-like, cerise flowers, blotched crimson. Nutmeg scented.

PRICES OF SWEET SCENTED GERANIUMS-30c each; 3 for 85c; 12 for \$2.90, postpaid.

\section{GERANIUM SEED}

A superb strain of the finest American and European varieties. Very interesting to grow from seed, and easily grown. Pkt.. 10e; 3 pkts., 25c.

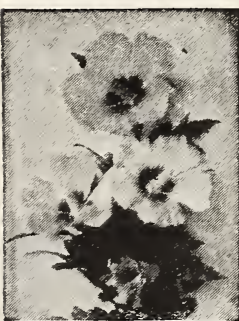

Hibiscus Africanus

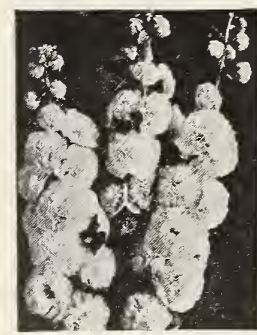

Double Hollyhock

ORNAMENTAL GOURDS (A). Calabash Pipe, Dipper, Dish Cloth, Japanese Bottle, Nest Egg, Pearshaped, and Sugar Trough. Your choice of these varieties at 10c per packet; 7 packets-one of each variety-40c.

Mixed Varieties. A fine mixture of rare, useful and ornamental varieties. Pkt., 10c; 3 pkts., 25c.

ORNAMENTAL GRASSES (A). Most useful for winter bouquets when combined with Everlastings or Strawflowers. Easily grown in any soil. A nice mixture of the finest varieties. Pkt., 8c.

GYPSOPHILA (Baby's Breath), Elegans White (A). Pure White; extensively grown by florists for use with other cut flowers. Pkt., 5c.

Elegans Rosea (A). Soft pink; exceedingly beautiful. Pkt., 5.

Paniculata (P). Very fine; superior to Asparagus Fern for mixing with other cut flowers Can be dried and used for winter bouquets. A most desirable addition to the hardy border. Pkt., 10c. Plants 30o each.

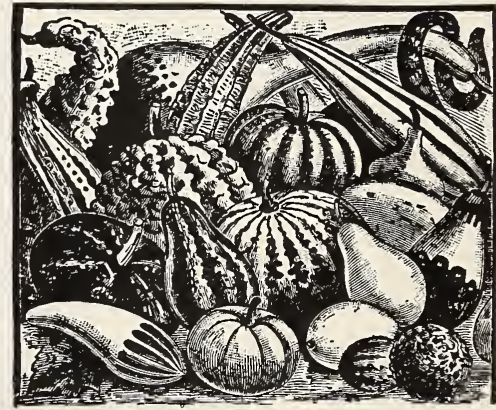

Ornamental Gourds

HELIOTROPE $(\mathrm{H})$. One of the most fragrant of all plants, and very beautiful. Fine for bedding, and one of the best winter house plants. Pkt., 10c.

HIBISCUS, Africanus (A). Large, saucer-shaped, cream-colored blossoms, dark purple center. 2 feet. Pkt., 8c.

Mallow Marvels (P). For prices of plants, description and picture taken from photograph of flowers grown on our seed farms, see inside front cover page. Fine mixture of colors. Pkt., 10c.

HOLLYHOCK, Prize Double (P). Mammoth flowers. Seed in mixture of colors only. Plit. 10c. Plants in separate colors-maroon, red, rose, salmon, white, yellow-30c each; 3 for 85e; 6 for $\$ 1.60 ; 12$ for $\$ 3.00$.

Allegheny (P). Enormous flowers; beautiful fringed petals. Colors vary from palest pink to deep red. Spikes 6 to 7 feet high. Pkt., 10c. Plants, in mixture of colors only, 30c each; 3 for $85 \mathrm{c} ; 6$ for $\$ 1.60$; 12 for $\$ 3.00$. 


\section{French or Porch Hydrangeas}

These Hydrangeas are especially adapted for pot or tub plants for indoor porch, lawn or garden decorations. In some soils the flowers turn blue, and this color can be secured artificially by mixing one-half pound of broken alum with each one-half bushel of soil.

Bouquet Rose. Deep rose-amber, turning to bright red, 40c each. Gen. DeVibraye. Large bright rose flowers. $40 \mathrm{c}$ each.

Mme. Emile Moullere. Pure white with rose-carmine eye. 40c each.

Red Globe. The darkest red variety. Unusually attractive. 40c each.

SPECIAL OFFER-One each of the above four Hydrangeas for \$1.50.

\section{HELICHRYSUM (Straw Flower)}

Mronstrosum (A). The largest of the Everlastings. Beautiful Aster-shaped flowers that, when dried retain much of their original shape and splendor. Popular for winter decorations, for which purpose the blossoms should be cut when about one-third open, tied in small bunches, and dried slowly in a cool, shady place, hanging the flowers downward to keep the stems straight. We can supply seed in the following separate colors: Fire Red, Golden Yellow, Crimson-Purple, Rose-Pink, Sa!mon-Rose, White. Pkt., 10c; 6 pkts., (one of each color) 40c. All colors mixed: Pkt., 10c; 3 pkts., 25c.

\section{JAPANESE HOP (Humulus Japonicus)}

Variegated-Ieaved (A). A rapid climber: one of the best plants for covering verandas, trellises, etc. The large handsome leaves are beautifully variegated, green and yellow, and make a dense covering. Pkt., 10c.

HELENIUM, Autumnale Rubrum (P). A splendid new variety. Deep oxblood red, changing to terra cotta. Round, bushy plant, 4 to 5 feet tall. One of the finest of all hardy perennials; succeeds in any soil; a mass of blooms in late summer and fall. Plants 35c each.

Riverton Gem (P). Old gold, changing to wallflower red. Plants 35c each.

ICE PLANT (A), Fine trailing plant for borders and

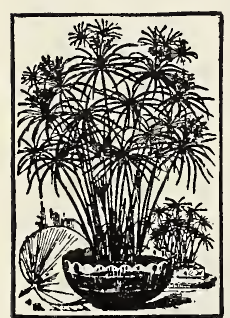

Umbrella Palm hanging baskets, and valuable for dry, sunny situations on banks, rockwork, old walls, etc. Foliage very ornamental, being covered with ice-like globules. Pkt., 5c.

IMPATIENS, Everblooming ( $H)$. One of the most beautiful and free bloomins bedding or house plants. They produce a great abundance of bright colored flowers which are well shown off by a background of heavy, rich foliage. Colors pink, orange-pink and brilliant vermillion. Continuous bloom may be expected from July to October. Plants 20c each.

IRIS, Kaempferi (Japanese Iris) (P). Flowers 10 to 12 inches in diameter; gorgeous combination of colors. Bloom later in the season than the German Iris. Pkt., 10c.

JAPANESE UMBRELLA PALM (H). Not a true palm, but handsome ornamental palm-like plant. Grows in water or soil. Indispensable for aquariums, fountains or pools. Pkt.. 10c. Plants 30c each.

JERUSALEM CHERRY (H). A very showy pot plant, loaded with ornamental "cherries," which turn to glossy scarlet when ripe. Fine for Thanksgiving and Christmas decoration. The bright cherries, which are not edible, will hang on the plant all winter; foliage always green and very ornamental. Pkt., 10c; 3 pkts., 25c.

JOB'S TEARS (A). Curious and ornamental. Seeds used for beads and ornamental purposes. Pkt., 5c; oz., 15c.

KOCHIA (Mexican Fire Plant or Burning Bush) (A). This beautiful bush grows about 2 to $2 \frac{1 / 2}{2}$ feet in height and resembles a closely trimmed ornamental evergreen. May be grown singly or in the form of a hedge or background. In early fall the entire bush turns bright scarlet. Pkt., 8c.

LANTANA, Everblooming Hybrids ( $\mathrm{H}$ ). One of the most desirable half-hardy perennial house or bedding plants. Verbena-like heads of orange, white, rose, crimson and various red shades; constantly in bloom. 2 to 3 feet. Fine mixture of colors. Pkt., 10c. Plants 30c each.

Weeping Lantana (H). New weeping plant of great beauty. Graceful drooping habit, grows very rapiely, and blooms continually summer and winter, producing large clusters of lilac or rosy-pink flowers; foliage beautiful dark green. Plants 30c each; 3 for 85c.

LARKSPUR, Double Giant Hyacinth-Flowered (A). The finest of all the annual Larkspurs; begin blooming early in July and give a continuous succession of flowers from then until frost, a record that is not surpassed by any other annual. Their free, graceful habit and bright colors make them very popular for beds, borders, and for cutting. A fine assortment of pink, lilac, flesh, white, dark rose and blue shades. 3 feet. Pkt., 10c.

All Sorts Mixed. Many different strains, kinds, colors and shades. Pkt., 5c.

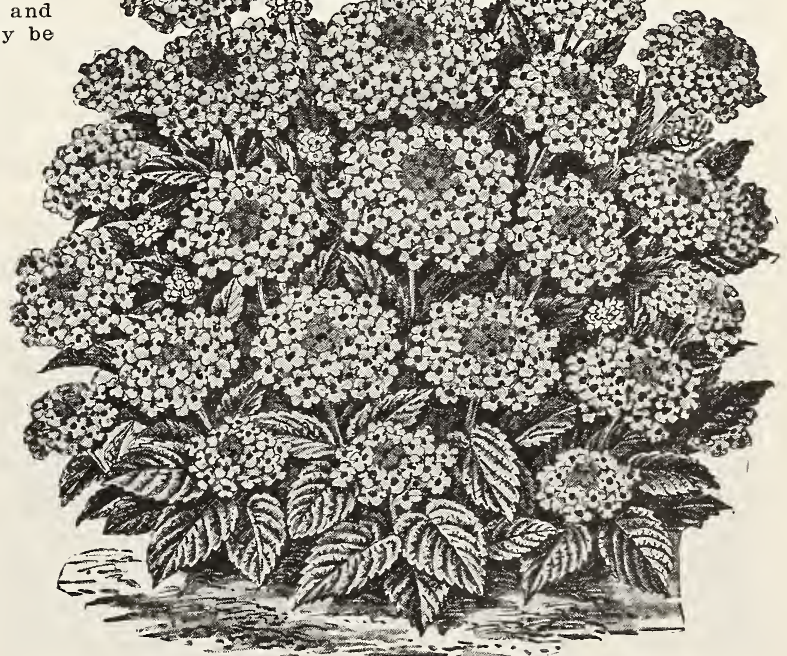

Lantana Everblooming Hybrids 


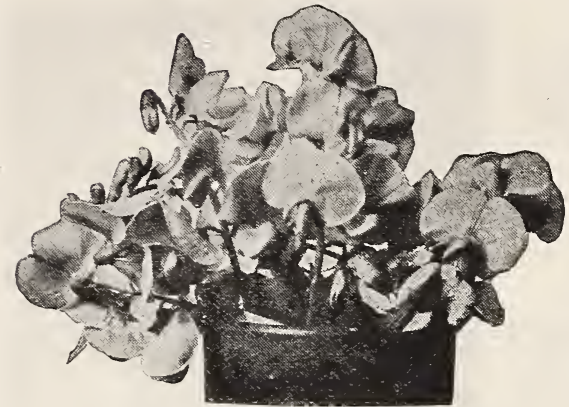

Lathy rus (Perennial Sweet Peas)

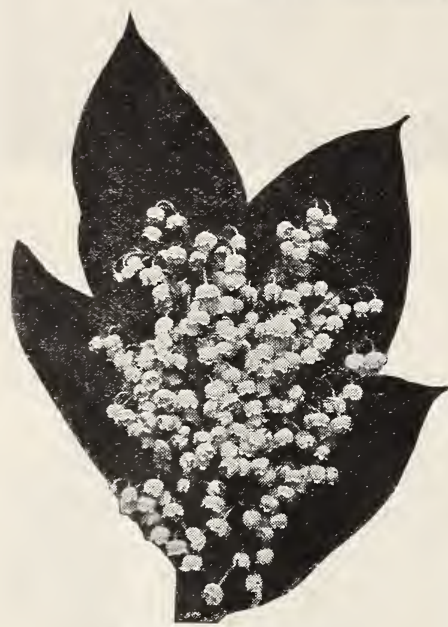

Lily of the Valley

\section{Lathyrus (Perennial Sweet Peas)}

Showy, hardy climbers that remain in the ground year after year; often 8 to 10 feet in height and bearing a mass of flowers throughout the summer. Fine for covering old stumps, fences, etc., and excellent for cutting. Mixed colors. Pkt., 10c. Plants 30c each; 4 for $\$ 1.00$.

\section{Lily of the Valley}

These popular and fragrant flowers do their best in a shady situation. A hardy perennial that is too well known to require description. 20c each; 3 for $40 \mathrm{c} ; 6$ for $60 \mathrm{c} ; 12$ for $\$ 1.00$.

\section{Blue Lily of the Nile}

A splendid ornamental plant with bright evergreen foliage spreading 3 or 4 feet and surmounted with spikes of bright blue flowers which remain in bloom for a long period. It is a most desirable tub plant for porch or lawn. Should be wintered in the cellar or greenhouse. Small plants 30c each; larger plants 60c; largest plants 90c.

LINUM, Grandiflorum Rubrum (Crimson Flax) (A). One of the most effective and showy bedding plants, having fine foliage and delicate stems, with brilliant scarlet-crimson flowers. 1 foot. Pkt., 5c.

Perennial Blue (P). Bright blue flowers; hardy; 18 inches. Pkt., 5c.

LOBELIA, Sapphire $(\mathrm{H})$. A beautiful trailing plant of strong growth; a mass of unusually large sapphire-blue flowers with a beautiful white eye; never out of flower. A most desirable pot and basket plant. Plants 25c each; 3 for 60c.

Hybrids $(\mathrm{H})$. Delicate blue and white flowers. Pkt., 8c.

LUPINUS, Annual Mixed (A). Free-flowering, easily grown annuals, with long graceful spikes of rich blue, rose and white pea-shaped flowers; valuable for mixed borders, beds, and for cutting; prefer a little shade. 2 feet. Pkt., 5c.

Polyphyllus, Blue $\left(\mathrm{P}^{\prime}\right)$. Long graceful spikes, three feet high, which are loaded with pea-shaped flowers. Fine for perennial beds and backgrounds and excellent for cut flowers. Pkt., 10c. Plants 30c each.

Polyphyllus, Rose (P). Same as above except color, which is a beautiful bright rose. Pkt., 10c. Plants 30c each.

Polyphyllus, White (P). Pure white, fine and stately. Pkt., 10c. Plants 300 each.

Polyphyllus, Mixed (P). A mixture of the above three colors. Pkt., 10c.

LYCHNIS, Chalcedonica (Rose Champion or Jerusalem Cross) (P). Handsome hardy perennial plant of easy culture, for massing in beds and borders; 2 feet. Brilliant scarlet flowers; suitable for cutting. Pkt., 8c. Plants 30c each.

MALVA (Musk Mallow), Moschata Rosea (P). A branching bush about 2 feet high, covered throughout the summer with beautiful delicate pink flowers, $11 / 2$ inches in diameter. Very useful for cutting. Pkt., 8c. Plants 30c each.

Moschata Alba (P). A white variety. Pkt., 8c. Plants 30c each.

MARIGOLD, Double Dwarf French (A). Few annuals are as effective or flower for so long a period; unsurpassed for borders or beds. 10 to 12 inches. A fine mixture of lemon-yellow, golden-yellow and rich, velvety mahogany-brown shades. Pkt., 5c.

Giant African Double (A). Immensely large, double quilled and imbricated flowers in all shades of yellow. Pkt., 5c.

MATTHIOLA, Bicornis (Evening Scented Stock) (A). The flowers of lilac color, appear in the morning, evening and after showers, and emit a delicious perfume perceptible at a considerable distance. Pkt., 5c.

MIGNONETTE, Sweet (A). The old variety with small spikes, but very sweetly

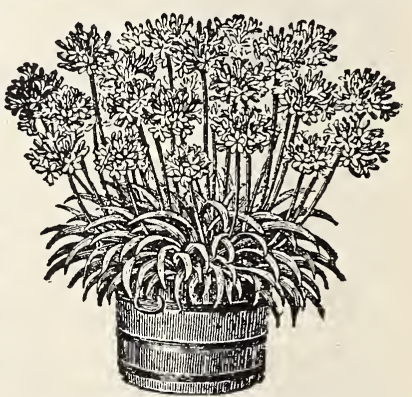

Blue Lily of the Nile scented. Pkt., 5c.

Superb Mixed (A). Many shades and types; very choice. Sowings made in April and again in July will keep up a succession of bloom from early summer until frost; can also be grown in pots for winter and early spring flowering. Pkt., 10c.

MIMOSA, Pudica (Sensitive Plant) (A). Curious and interesting plant with pinkish-white flowers. The leaves close and droop when touched or shaken. Pkt., 5c.

MORNING GLORY, Double Mixed (A). Double and semi-double flowers. Pkt., 8c.

Dwarf (A). Valuable for beds and borders; also as a winter-blooming house plant. 10 to 12 inches tall. Will thrive anywhere as long as they get plenty of sunshine. A fine mixture of colors. Pkt., 5c.

Japanese Giants (A). This is a particularly attractive variety with large, deeply lobed leaves. The flowers are
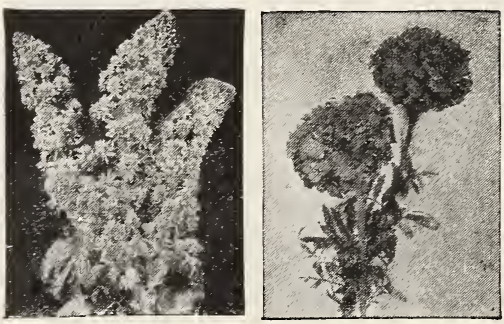

Mignonette
G. Af. D. Marigold

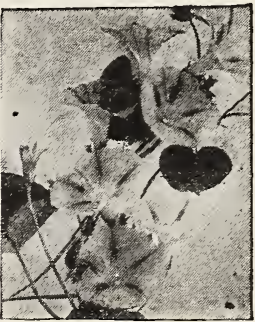

Morning Glory much larger than ordinary Morning Glories. The colors run from snow white through all possible shades of blue and red, from palest pink to darkest reds and purples, and streaked, mottled and bordered in wonderful fashion. Pkt., 8c.

Japanese Extra Large (A). A superior strain of Japanese Giants; extraordinary fine colors and gigantic in size, measuring 6 inches across. Pkt., 15c.

Japanese Fancy Fringed (A). A choice strain of Japanese Morning Glories with fringed and ruffled flowers. Pkt., 10c.

Superb Mixed (A). All the plain colors, variegated, mottled and striped. This mixture contains none of the above varieties, but is a fine mixture of the old fashioned sorts. Very hardy, so can be planted earlier and will begin to bloom earlier than the Japanese varieties. Pkt., 5c; oz., 15c. 


\section{Nasturtiums}

\section{DWARF SORTS}

For ease of culture and duration of bloom, brilliancy of coloring and general excellence, nothing excels Nasturtiums. All they need is moderately good soil in well-drained, sunny position, and from within a few weeks after seed is sown until hard frost comes there is an endless profusion of their gorgeous blossoms.

AURORA. Bright chrome-yellow flowers attractively veined with purplish carmine. The color contrast is particularly striking. Rich, deep green foliage.

CLOTH OF GOLD. Brilliant scarlet flowers on long stems; bright golden yellow foliage.

DWARF VESUVICA. Immense blooms of exquisite salmon-rose, beautifully marked with salmon-orange veins; dark green foliage.

EMPRESS OF INDIA. Rich salmon-scarlet; deep purplish green loaves.

GOLDEN KING. Glowing orange-yellow; dark purplish green foliage.

GOLDEN MIDNIGHT. Rich dark red blooms; light golden yellow foliage.

PRICES-Your choice of above six varieties at 5e per packet; 20c per oz.; six packets (your choice of varieties or one of each), 25c.

\section{DWARF SORTS IN MIXTURE}

DWARF GOLDEX-LEAVED VARIETIES. A splendid mixture of many golden-leaved sorts; blossoms of all colors. Fine for borders. Pkt., 8c; oz., 25c.

DWARF IVY-LEAVED. Flowers well up above the foliage, and beautifully fringed at edges. Blossom in greater profusion than any other variety of Nasturtium and remarkable for their colors and color combinations not found in any other strains; foliage having a marked resemblance to that of the hardy English Ivy. Plkt. $8 \mathrm{c}$; oz., 25c.

DWARF VARIEGATED LEAVED. Handsome foliage plant with flowers of many bright colors. Each leaf is in a different degree beautifully marked with yellow, white and green, so that the plants would be worthy of culture almost for the foliage alone. Very showy and blooms freely and continuously. Pkt., 8c; oz.. 25c.

DWARF MIXED. A fine mixture of all colors and kinds; yellow, rose, crimson, scarlet, brown, spotted, striped and splashed. Pkt., 5c; oz., 15c; 1/1 lb., 40c.

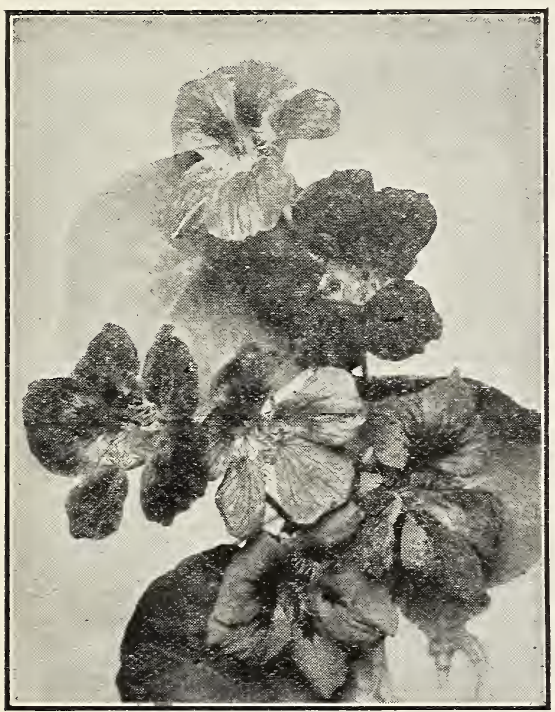

Tall Nasturtiums

\section{TALL SORTS}

BUTTERFLY. Light lemon-yellow, attractively marked on the three lower petals with a blotch of rich terra cotta red; the two upper petals marked in shades of bright red; large flowers and long stems.

shades of bright red; large flowers and long stems.

DUNNETT'S ORANGE. Rich deep orange with deep crimson blotches. EDUARD OTTO. Brownish lilac.

FORDHOOK FASHION. Bright cherry-rose, overlaid with deep veinings of old rose: blossoms of exceptional size; deep blue-green foliage.

MIDNIGHT. Deep brownish red, of soft velvety texture, resembling polished mahogany; rich deep green foliage.

TALI VESUVIUS. Salmon-rose with salmon orange veins; dark green foliage.

PRICES-Your choice of above six varieties at $5 \mathrm{c}$ per packet; 20c per oz.; six packets (your choice of varieties or one of each), 25c.

\section{TALL SORTS IN MIXTURE}

TALL IVX-LEAVED. Fine fringed petals; colors intense and very striking; ivy-like foliage and vines exceedingly graceful. Pkt., 8c; oz., 25̃c.

TALI VARIEGATED-LEAVED. Light green foliage, beautifully marbled and blotched with white. Makes a striking vine with its bright blossoms of many colors. Pkt., 8c; oz., 25c.

TALL MIXED. Our special mixture contains all the choicest colors and many kinds and types of Tall Nasturtiums. Pkt., 5c; oz., 12c; $1 / 4$ lb., 35c.

\section{Moonflower}

Sweet Scented Giant Flowered (A). A rapid climber, reaching a height of 20 to 30 feet; foliage very dense. Every evening and on cloudy days the vines are covered with immense flowers of delicate coloring, many measuring 6 inches across. Pkt., $10 \mathrm{c}$.

\section{MYOSOTIS (Forget-Me-Not)}

Few spring flowers are more admired than the lovely Forget-Me-Nots, which are especially effective when grown in masses. The Alpestris varieties are biennial and come into bloom very early in the spring and are largely used for bedding or borders in connection with spring-flowering bulbs, Pansies, etc. They also bloom again in the fall; bloom freely the first season and still more profusely the second spring. They do best in shady, moist situations.

Alpestris, Blue (B). Dwarf bushes of trailing habit. A mass of light biue flowers which stand out sharply from the rich green foliage. Pkt., 10c:

Alpestris, Rose (B). Beautiful rose-pink; a color rather rare among Forget-Me-Nots. Pkt., 10c.

Palustris Semperflorens (Perpetual Flowering) (P). This lovely perennial Forget-Me-Not is of everblooming type. Flowers of lovely bright sky-blue color; begin to flower about a month later in the spring than the biennial varieties and continue blooming until late autumn. Pkt., 15c. Plants 30c each. 4 for $\$ 1.00$.

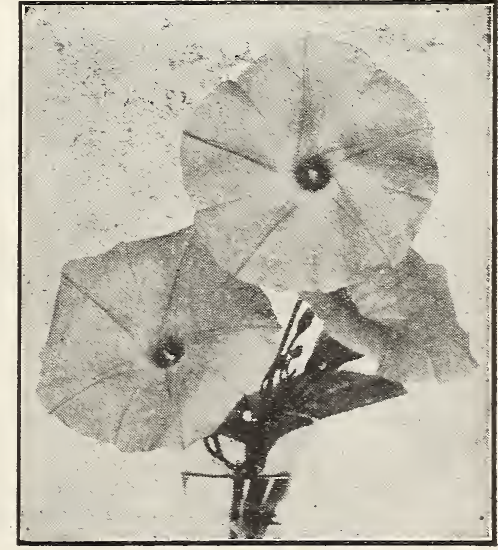

Moonflower 


\section{Night Blooming Jasmine}

The Night Blooming Jasmine (Cestrum Parqui) is a highly prized house plant. The foliage is a deep green color; produces richly fragrant blooms: very fragrant at night. Plants 35 e each; 3 for $\$ 1.00$.

NICOTIANA, Affinis Hybrids (Tuberous-Flowered Tobacco) (A). Compact bush, about 3 feet high; blooms all summer and fall; delightfully sweet-scented, tube-shaped white, purple, red, salmon, pink and violet flowers. Pkt., 8c.

NIGELLA, Damascena (Love-in-a-Mist) (A). A compact, free-flowering plant, with finely cut foliage, pretty blue and white flowers and curious looking seed pods; of easy culture, growing in any garden soil. $1 \frac{1}{2}$ feet. Pkt., 5c.

OENOTHERA (Evening Primrose) (A). Neat plants; large saucershaped flowers; white and yellow; emit a delightful perfume. Pkt., 5c.

\section{Ornamental Cotton}

Many people in the North have never seen cotton growing. As it is by far a more beautiful plant than many of the ornamentals and can be successfully grown in the North for ornamental purposes, it makes a very desirble addition to any flower garden. This is a great novelty for the Northern gardener, and always attracts the attention of both the grown-ups and the children. Start seed early and transpiant. Has large, showy flowers, followed by large fluffy balls of white cotton. Pkt., 5e; 3 pkts., 10c.

OXALIS, Tropaeloides (A). An excellent little plant for edging or pots; blooms all summer in the greatest profusion; yellow flowers, rich brown foliage. Pkt., 10c.

\section{Pansies}

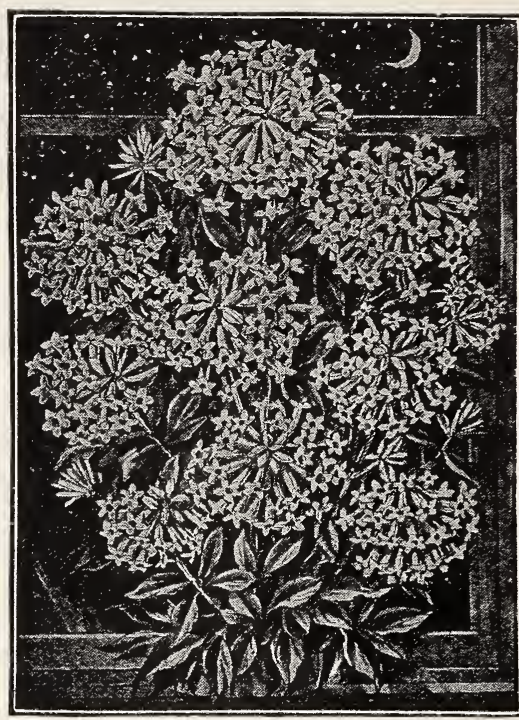

Night Blooming Jasmine

Pansies are favorites with all, and are too well known to require any description. For best results you must start with a good strain. We spare neither pains nor expense to satisfy the most critical trade our seed is produced and saved with great care and is the best. The finest Pansies are, as a rule, shy seeders, which accounts for the difference in the price of the various mixtures.

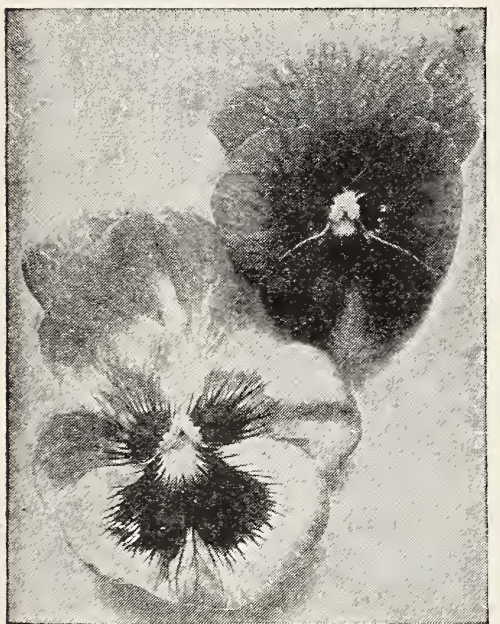

Giant rowered ransies

BURGESS, BEST GIANT FLOWERED. The largest and most beautiful of all. The finest collection of colors and variations of colors, with the gigantic blossoms well above the foliage, erect on long, stiff stems. Without an exception, the finest mixture ever offered, both as regards size and colorings; none better at any price. Fkt., 25c; 3 pkts., 65c.

GIANT RUFFLED MASTERPIECE, Giant-sized flowers of most striking character, each petal being conspicuously curled or waved, giving them the effect of a double flower. The colors are mainly rich dark shades, bordered, blotched, or marked in ray-like veinings with contrasting colors. Bloom freely and continuousiy as long as the weather remains cool. Pkt., 20c; 3 pkts., 50c.

MAMMOTH ORCHID-FLOWIERED. This distinct and beautiful strain of Pansies will appeal to those who prefer delicate tints and soft shades and colors. The unique colorings include shades of chamois, terra cotta, pink, lilac, rose and orange. The flowers are of good size and they bloom freely from early spring until late in the fall. The name "Orchid-Flowered" has been given them because of their delicate shades and finely ruffled edges. Pkt., 15e; 3 pkts., 40c.

EXTRA FANCY LARGE FLOWERED. A fine mixture, similar to Burgess' Best Giant Flowered, but blossoms not quite as large. Pkt., 10̃e; 2 pkts., 25̃c. $8 \mathbf{c}$

CHOICE MIXED. A fine mixture of the ordinary varieties of Pansies. Pkt.,

\section{PANSY PLANTS}

Our Pansy plants are grown from a choice mixture of the best American strains, comprising a marvelous number of new shades and varieties, as well as improved types from leading European growers. All are of wonderful form, richest coloring and marvelous in size. The combination of colors embraces striped, spotted, bordered and fringed, in rainbow colors, with rich velvety textures. Petals crimpled, curled, ruffled, blotched; wonderful colors, striking markings. No flower border, be it ever so gay and gorgeous, is more interesting and more admired than Pansies. Plants set out as soon as the frost is out of the ground in the spring will begin to bloom at once and afford daily pleasure. Plants 75c per doz.; 6 for $40 \mathrm{c}$.

\section{Petunias}

For outdoor decoration, porch or window boxes, few plants equal the Petunia in effectiveness. They commence flowering early and continue a sheet of bloom until killed by frost.

GIANT FLOWERED HYBRIDS. A wonderful assortment of colors; mammoth in size. Pkt., 15 c.

GIANT FRINGED. Flowers of extraordinary size, deeply fluted, ruffled and fringed; varied and brilliant colors. Pkt., 20c.

TRIUMPH OF THE GIANTS. The largest and finest single Petunia. Flowers often measure 7 inches across. A variety of gorgeous colors and markings that is unsurpassed. Pkt., 25c.

GOOD MIXED. A splendid mixture of single bedding varieties. Pkt., 8c.

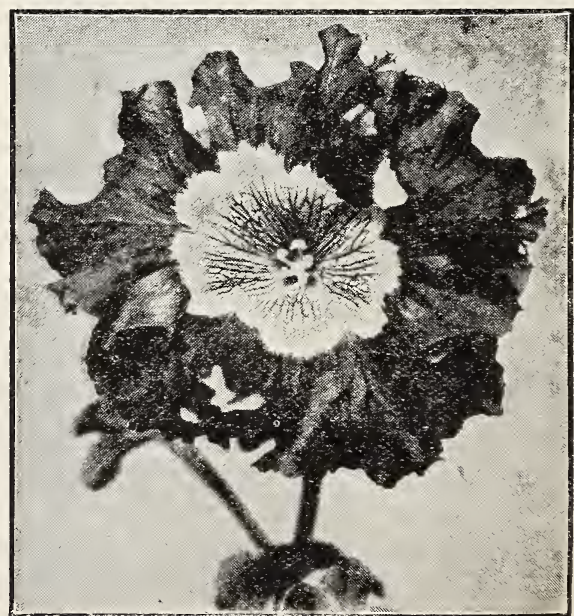

Petunia Triumpl of the Giants 


\section{Phlox Drummondi (Annual Phlox)}

The annual Phlox is one of the most brilliant and one of the easiest and most satisfactory plants which can readily be grown from seed. It will grow and thrive in any kind of soil if given a sunny position. In a few weeks after the seed is sown the plants are a sheet of bloom, remaining so until frost. They show to best advantage when grown in masses, beds or borders; excellent for cut flowers. The following colors are of the finest type, having the largest heads of blooms as well as the largest individual flowers, of strong, sturdy growth, attaining a height of about 15 inches.

Brilliant Scarlet. Pkt., 8c.

Deep Rose. Pkt., 8c.

Yellow. Pkt., 8c.

Soft Shell-Pink. Pkt, 8c.

Violet-Blue. Prkt., 8c.

IAARE-FLOWERING MIXED (A). All of the above colors as well as a great many others. Pkt., 8c.

STAR PHLOX (A). The flowers are either starred or fantastically fringed. A novel variety; many bright shades; mixed colors. Pkt., 10c.

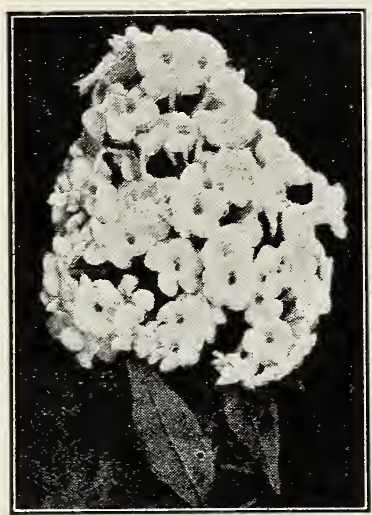

Perennial Phlox

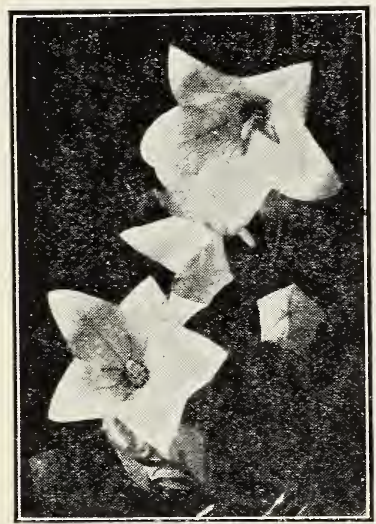

Platycodon

\section{Hardy Perennial Phlox}

Our new improved Perennial Phlox are revelations of beauty, with enormous sized flowers, and absolutely hardy everywhere. The long blooming period, from July to October, and the bright, showy colors make them indispensable for landscape work, massing, and cutting. We can supply fine plants in the following separate colors: Crimson, Bright Pink, Salmon-Pink, Purple, Scarlet, White. 30c each; 3 for $80 \mathrm{c} ; 6$ for $\$ 1.50$.

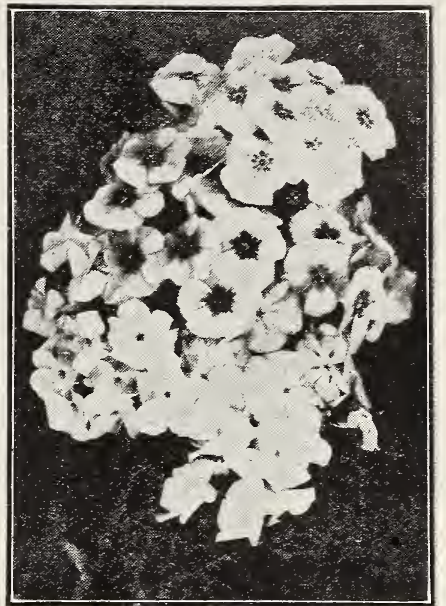

Phlox Drummondi

\section{Everblooming Hardy Phlox}

Miss Lingard ( $P$ ). This grand variety starts to bloom much earlier than other sorts and continues to flower until late in October. Handsome, long spikes of white flowers with lavender-pink eye. Height about 2 feet. Admirably adapted for the flower garden and for cemetery planting. Plants 35c each; 3 for $\$ 1.00$.

\section{Phlox Subulata (Moss Pink)}

Dwarf, trailing perennial plants with moss-like evergreen foliage, which, during early spring, is hidden under a mass of bloom. An excellent plant for the rockery and the border, and invaluable for carpeting the ground or covering graves. 4 inches. Plants in separate colors-White, Light Blue, Bright Rose-30c each; 3 for $80 \mathrm{c}$.

PENTSTEMON (Beard Tongue), Barbatus Torreyi (P). A handsome plant with graceful stems, 3 to 4 feet high, and covered almost the entire length with brilliant coral red flowers, from June to August. Highly useful for the hardy border and for cutting. Plants 35e each; 3 for $\$ 1.00$.

PHYSOSTEGIA (False Dragonhead), Virginica (P). One of the most beautiful nid-summer flowering perennials. Dense bushes, 3 to 4 feet high, bearing long spikes of delicate lavender-pink tubular flowers. Plants 25c each.

PLATYCODON (Japanese Bellfower) (P). One of the best hardy perennials, producing large, showy bell-shaped flowers during the whole season. Branching bushes 2 to 3 feet, easily grown from seed and bloom the first season. Seed in mixture of colors only. Pkt., 10c. Plants in separate colors-blue or white-35c each; 2 for 60c.

PORTULACA, Giant Flowered Mixed (A). One of the showiest low annuals, of easy culture, thriving best in light loam or sandy soil and in a sunny situation. Fine for massing in beds, edgings or rock-work, and frequently used to sow broadcast over sunny banks, etc. 6 inches. Flowers of the richest colors. Pkt., 5c.

Double Rose Flowered (A). Unsurpassed for brilliancy and beauty. Seed saved from perfect double flowers, so will produce a large percentage of double blossoms. All colors mixed. Pkt., 10c.

PYRETHRUM, Aureum (Golden Feather) (P). Beautiful rich yellow foliage; small pure white flowers; one of the best plants for edging, carpet bedding, etc. 6 inches. Most successfully treated as an annual. Pkt., 8c.

Roseum (Painted Daisy), Mixed ( $\left.P^{\prime}\right)$. Fine showy,

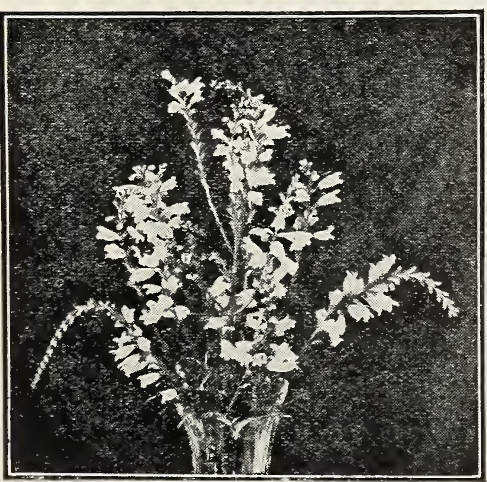
well-rounded plants 2 to $2 \frac{1 / 2}{2}$ feet tall, with finely cut, fern-like foliage. The large, bright, daisy-like flowers are invaluable for cutting, being borne on long stems and lasting a long time. They range in color from pure white and light pink to brilliant scarlet and dark red, with bright yellow centers. Although they bloom practically all summer, they are at their best in June. Perfectly hardy and easily grown. Pkt., 10c. Plants 30c each; 6 for $\$ 1.50 ; 12$ for $\$ 2.65$.

\section{We Pay the Postage}

All Seeds and Plants listed in this catalog are delivered prepaid at the prices given unless otherwise stated.

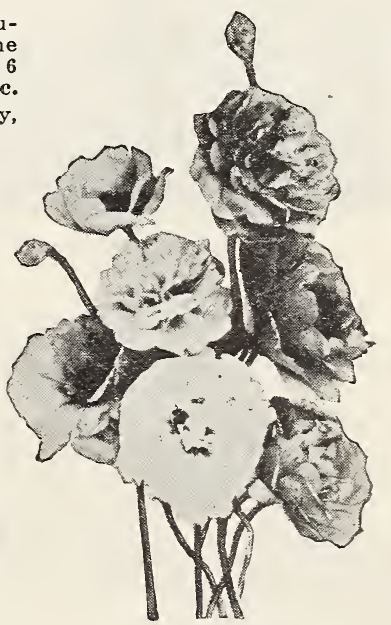

Double Portulaca 


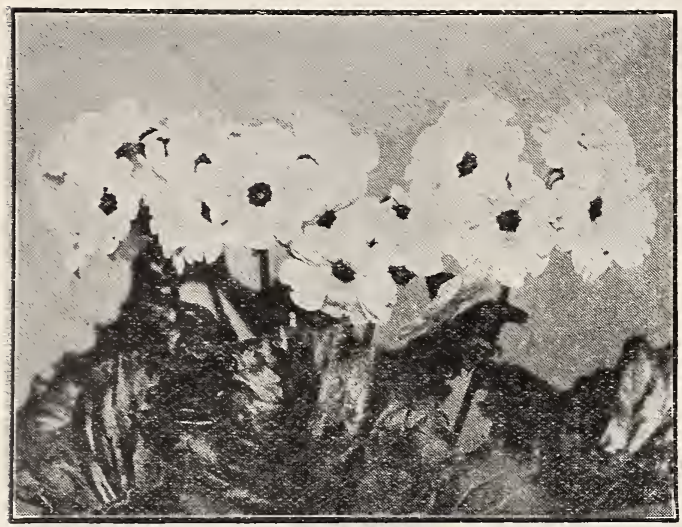

Primrose Obconica Grandiflora

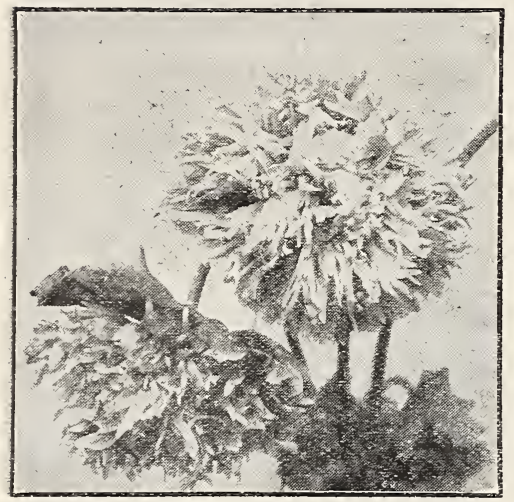

Double Carnation-Fiowered Poppies

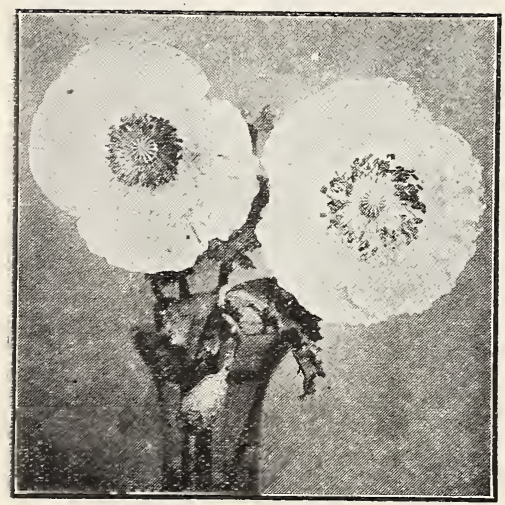

Iceland Poppies 12 for $\$ 2.50$.

\section{Poppies}

DOUBLE CARNATION-FLOWERED (A). Splendid double fringed flowers; mixed colors. Pkt., 5c.

DOUBLE FEATHER BALL (A). Mammoth globe-shaped, elegantly fringed flowers. Very beautiful and easily grown: mixed colors. Pkt., 8c.

DOUBLE PEONŸ-FLOWERED (A). Large, showy, double globular flowers, resembling a double Peony; mixed colors. Pkt., 5c.

SHIRLEY (A). The finest single Poppy; beatiful shades of rose, apricot, salmon-pink, and blush to glowing crimson with a sprinkling of bluish shades. Pkt., 8c.

DOUBLE MIED (A). Many double sorts; mixed colors. Pkt., 5c.

SLNGLE MIXED (A) Many single sorts; mixed colors. Pkt., 5c.

DOUBLE AND SINGLE MIXED (A). A fine assortment of all colors; double and single mixed. Pkt., 5c.

\section{Iceland Poppies}

While these are hardy perennials, they flower the first year from seed, blooming almost as quickly as the annual sorts. They are of graceful, neat habit with bright green fern-like foliage, formed in tufts, from which issue slender stems about 12 inches high, bearing their brilliant flowers in endless profusion; most useful for cutting, for which purpose they should be picked when in bud. By keeping the seed pods picked off, they will continue in flower the entire season. They remain evergreen throughout the winter, coming in bloom early the following spring.

BRIGHT YELLOW (P). Pkt., 10c.

ORANGE-SCARLET (P). Pkt., 10c.

WHITE (P). Pkt., 10c.

FINEST MIXED (P). All colors. Pkt., 10c. Plants 30c each; 6 for $\$ 1.40$;

\section{Oriental Poppies}

Oriental Hybrids (P). For brilliancy in color nothing equals them. Flowers of enormous size, often measuring over 6 inches in diameter; colors range from rose and salmon-pink to the most brilliant dazzling scarlet and rich maroon purple. A perfectly hardy perennial. See inside front cover for picture in colors. Pkt., 10c. Plants 35e each; 3 for $\$ 1.00$.

\section{Primrose}

Obconica Grandiflora $(H)$. One of the finest and most important winter blooming pot plants. Can be easily grown in any light window, flowering abundantly and continuously with little care. The seed we offer is saved from the finest, freest flowering varieties, and from a choice assortment of colors, from pure white and soft pink through the different shades of rose and red to the brightest crimson. Pkt., 25c.

Baby Primrose (H). It forms a dense rosette of somewhat fleshy leaves, from which spring flowering stems, 12,15 and 20 inches tall, supporting three tiers of whorls of dainty flowers of a delicate rosy lilac, with eye of pale gold. No seed. Plants $35 \mathrm{c}$ each; 3 for $\$ 1.00$.

Polyantha (Hardy Primrose) (P). Showy, early spring, free-flowering plants, fine for either pot or outdoor culture; hardy perennial; 9 inches. A fine mixture of colors from purest white to the richest crimson. No seed. Plants, 350 each; 3 for $\$ 1.00$.

\section{RICINUS (Castor Oil Bean)}

Giant Zanzibar (A). A distinct class, which surpasses in size and beauty all other varieties. From seed of this variety, sown in the open ground in May, the plants are in full foliage early in July; attain a height of 12 to 14 feet and form a perfect pyramid of foliage and brilliant colored fruit, presenting a beautiful tropical appearance. The varieties included in our mixture have light and dark green leaves and some of coppery-bronze, changing to dark green with reddish ribs; leaves enormous in size, measuring from 2 to 3 feet across. Pkt., 10c; oz., 20c.

RANUNCULUS (Buttercup) (P). A pretty double flowering bright golden yellow buttercup, blooming in great abundance in May and June. 12 inches. Effective either as a cut flower or grouped in the hardy border. Plants 30c each; 3 for 85 c.

RUDBECKIA, Golden Glow (P). A well known popular plant of strong, robust growth; 5 to 7 feet. Masses of double golden-yellow Dahlia-like flowers from July to September. Plants 25e each; 3 for 60c; 12 for $\$ 2.00$.

SALPIGLOSSIS (A). One of the finest annuals, and of easy culture; 18 to 24 inches high; velvety funnel-shaped blossoms in a very large and unusual range of colors; crimson, primrose, purple and gold, rose and gold, scarlet and gold, white and gold, etc. Continually in bloom from mid-summer until frost; splendid for cutting. Pkt., 10c.

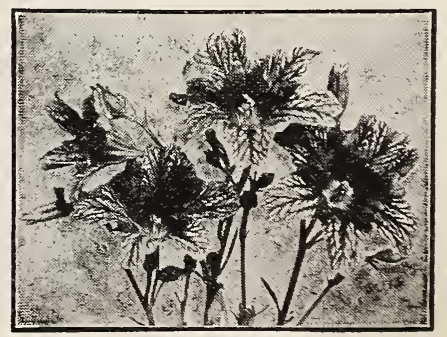




\section{Salvia Splendens ( $\left.\begin{array}{c}\text { Scarlet } \\ \text { Sage }\end{array}\right)$}

Splendens (Scarlet Sage) (A). The Salvia Splendens has long been a favorite bedding plant, bearing long spikes of brilliant fiery scarlet flowers in great profusion from July to frost. This is the old reliable variety; spikes 3 feet high; none of the new varieties will equal it. Pkt., 10c; 3 pkts., 25c.

\section{Hardy Perennial Salvia}

Azurea Grandiflora (P). Tall spikes of pretty sky-blue flowers in great abundance during August and September. 3 to $3 \frac{1 / 2}{2}$ feet. Plants 30c each; 3 for 85c.

SCABIOSA (Mourning Bride or Pin Cushion Flower) (A). A popular plant; grows about $2 \frac{1 / 2}{2}$ feet high, producing beautiful flowers of exquisite shades of pink, rose, cherry red, fiery scarlet, white, yellow, amethyst, lavender, light blue, dark blue and purple, the soft shades predominating. Begin blooming early in July, and when given plenty of room and the seed vessels are kept regularly picked off, will continue blossoming through the whole summer. Long stems; blossoms keep well in water. A fine plant for the flower bed; its floral flavors attract all the most beautiful types of butterflies to the neighborhood. Choice mixture of colors. Pkt., 5c.

SCHIZANTHUS (Butterfy or Fringe Flower) (A). This

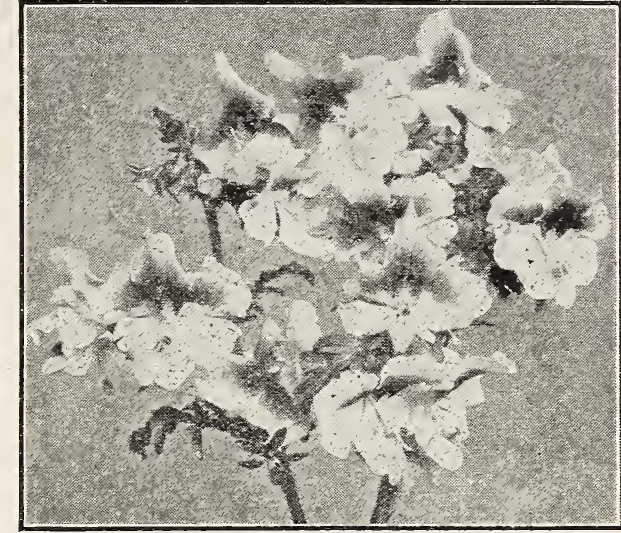

Schizanthus

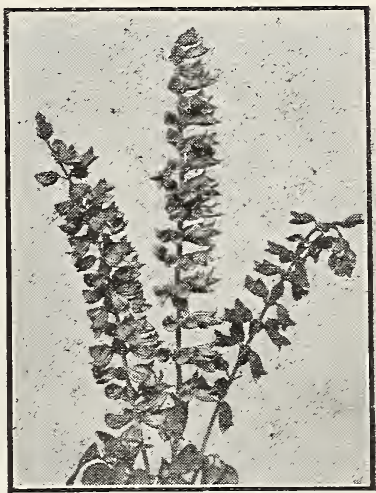

Sauvia

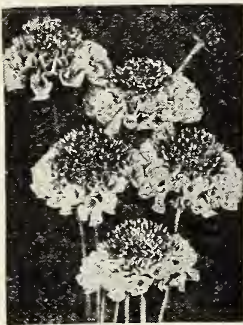

Seabiosa

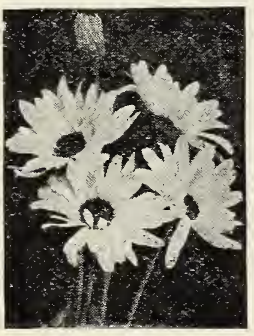

Shasta Daisy is one of the daintiest flowers imaginable; especially fine for bordering beds of taller flowers, and as pot plants for the house in late winter and early spring. Seed sown in the pring will produce plants that wili come into bloom in a completely obscure the delicate fern-like foliage. If wanted for house plants for winter blooming, sow in the autumn. The plants will quickly grow into compact, rounded bushes, about 2 feet tall. The butterfly-like flowers range in color from pure white through shades of cream and pink to crimson and mauve. Many of the flowers are beautifully marked. Pkt. 10c: 3 pkts., 25c.

SHASTA DAISY, King Edward (P). The largest of all daisies, flowers frequently measuring more than 5 inches across. An improvement over the common Shasta Daisy, and will stand the winter where the old variety freezes out. florist's use. Pkt., 10c. Plants 30c each.

SILENE, Armeria (Catchfly) (A). A very showy earlyflowering hardy annual about one foot in height, bearing in quantity, heads of beautiful white, pink and red flowers. Any garden soil is suited to growing these free-blooming, showy plants, but they do best if not given too much care. Pkt., 5e.

SILK OAK TREE (H). A magnificent plant for decorative purposes, of rapid, easy growth, fully cut foliage, and rivaling a rare Fern. Called "Silk Oak" on account of its beautiful foliage. Plants 30c each; 3 for $85 \mathrm{c}$.

SMILAX (H). One of the most desirable and graceful window vines. The slender stems are covered with small, glossy green leaves. A fine plant for hanging baskets or window boxes. Elegant for bouquets and floral decorations. Pkt., 8c.

SNAKE PLANT, (H). A most striking decorative foliage plant. Very odd, beautiful and easily grown. No other house plant stands as much downright neglect and hardship. Nothing but frost or continued drenching with water seems to hurt it. It will stand gas and dust and will go for months without a drop of water. Plants 35c each; larger size 75c

STATICE, Sinuata, Deep Blue (A). Not only one of the most beautiful flowers for the border, but dries retaining its true color, which makes it one of the most valuable of Everlastings; indispensable in making winter bouquets. Pkt., 8c.

Sinuata, Deep Rose (A). A rose-colored form of above. Pkt., 8c.

Latifolia (Great Sea Lavender) (P). Exceedingly fine for cutting and floral work. Minute purplish flowers fronı June to August. 2 feet. No seed. Plants 35e each; 3 for \$1.00.

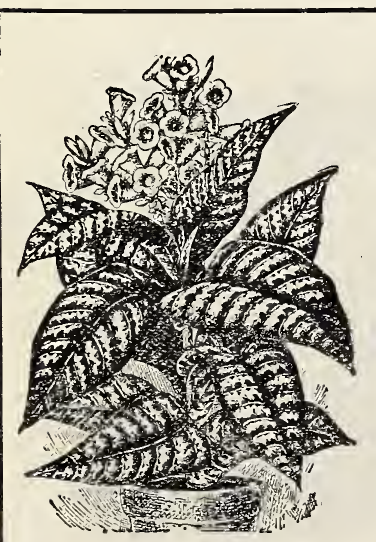

\section{ROYAL PURPLE PLANT}

The Royal Purple Plant (Strobilanthes Dyeranus) is universally popular on account of its brilliant and exquisite coloring. Surpasses the finest Coleus or Begonia in the color of its leaves. Plants 35 each; 3 for 90 c

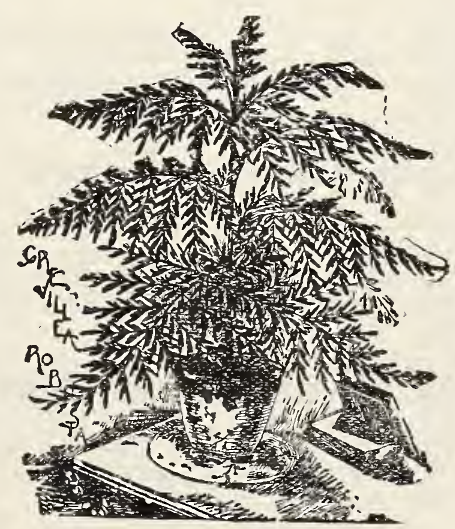

silk Oak Tree

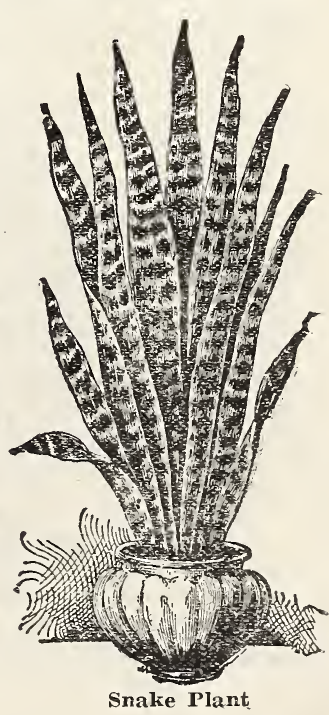




\section{Burgess' Prize Spencer Sweet Peas}

The Spencer or Giant Ruffled is the finest type of Sweet Peas grown. Beautifully formed flowers, many measuring 2, to $2 \frac{1}{2}$ inches across, and petals daintily waved and muffed. Unsurpassed as cut flowers. We list only the best of each color and every lover of Sweet Peas should plant some of all of these selected varieties.

ASTA OHN. Charming soft lavender; one of the most beautiful Spencers.

BARBARA. Soft salmon. Finest Sweet Pea of its color. BROCAUE. A combination of salmon, lavender and pink; satiny finish.

CHERCB. A deep rich cream, charmingly edged with bright rose.

COUNTESS. Clear soft, rich pink. The finest pink variety.

LLUMLATOR. Brilliant glowing orange-scarlet. A most attractive variety.

IRISH BELLE. A lovely rich lilac flushed with pink.

KING EDWARD. Rich crimson; a most magnificent variety.

KING WHITE. The finest white Spencer; gigantic in size.

MRS. CUTHBERTSON. Rose-pink; wings white.

MTRS. TOWNSEND. White, edged light blue a round both standard and wings.

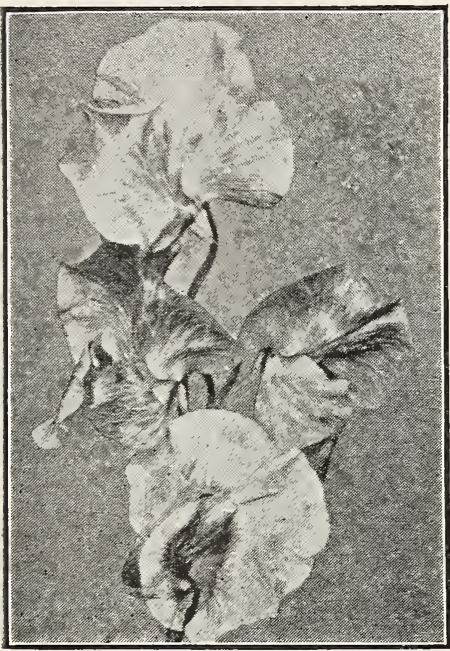

Prize Spencers

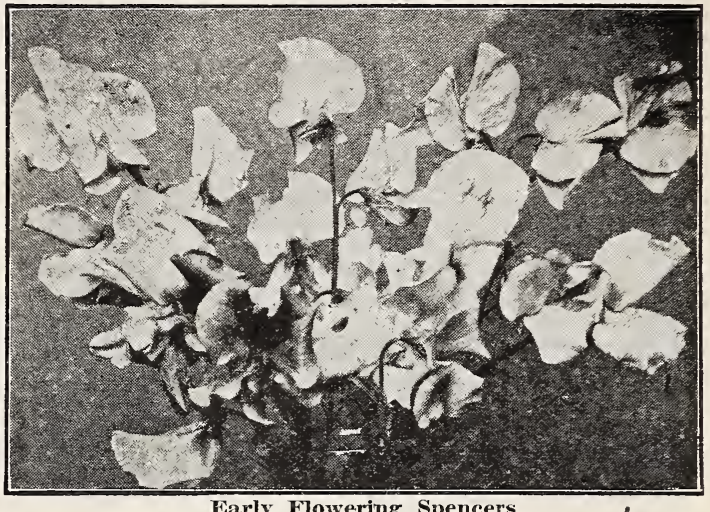

Early Flowering Spencers

ORCHID IMPROVED. Lavender, suffused pink; same shade as the Cattleya Orchid.

PRESIDENT HARDING. Salmon-cerise, suffused orange; an entirely new color in Sweet Peas.

ROBERT SYDENHAM. A magnificent glowing orange.

ROYAL SALUTE. A rich fiery cerise; bright and outstanding.

SENATOR. A combination of deep chocolate and claret striped and flaked on light heliotrope.

VALENTINE. Light shell pink; the finest of its color.

WARRIOR. Rich maroon flushed with bronze.

WEDGEWOOD. Deep azure-blue. The best blue variety.

PRICES: Your choice of any of these Prize Spencer varieties at 10c per packet; 25 c per $1 / 2$ oz.; 40c per oz. 3 pkts., 20c; 7 pkts., $40 \mathrm{c}$; or all 19 for $\$ 1.00$.

BURGESS' SELECTED MIXTURE OF SPENCERS is composed of the very finest varieties, and is the most gorgeous mixture of Spencers ever offered. It contains the cream of the very finest named Spencer varieties, including many recent novelties and superb new seedlings not yet introduced. It is the very best blend possible to produce and will surely delight all who want a grand variety of shades and colors. Pkt., 10c; 3 pkts., 20c; oz., 30c; 1/4 1b., 90c.

\section{Early Flowering Spencer Sweet Peas}

Our Farly Flowering Strain of Spencer Sweet Peas is the result of more than ten years' careful scientific work. These varieties will not flower as freely and continuously as the late sorts, but will begin flowering from one to three weeks sooner, which is a decided advantage where early blooms are an important consideration. They are invaluable to florists for greenhouse culture; for outdoor planting in sections of the Southern States where later varieties can not be successfully grown; and for early blooms in cool climates.

ACRORA. White, artistically flaked rich orange-scarlet. BLUE JACKET. Rich, dark navy-blue.

CANARY BIRD. A splendid rich deep cream or primrose color.

DAINTINESS. Pure white, edged rose.

EARLY KLNG. The best early flowering crimson.

FLAMINGO. The finest early flowering orange colored variety.

GLORIUS. A charming shade of Royal Purple.

GRENADIER. Bright dazzling scarlet.

HARLEQUN. Heliotrope, striped chocolate.

PRICES: Your choice of any of the above varieties at $10 \mathrm{c}$ per packet, 350 per $1 / 2$ oz., 60c per oz. 3 pkts., $25 \mathrm{c}$; 7 pkts., 50c; or all 15 for $\$ 1.00$.

BURGESS' SPECIAL MIXTCRE OF EARLY FLOWERING SWEET PEAS. Pkt., 10c; 3 pkts., 25c; 1/2 oz., 30c; oz., 55c; 1/4 lb., \$1.65.

\section{Standard Varieties Mixed}

This mixture of Sweet Peas is the best of the old standard or Grandiflora varieties; a fine mixture of all colors and shades. There are no Spencers in this mixture. While it is our cheapest mixture and can not be compared to the Spencer varieties, it is the best for the money that can be given. Pkt., 5c; oz., $12 \mathrm{c} ; 1 / 4$ lb., $35 \mathrm{c}$.

\section{Cupid or Dwarf Sweet Peas}

The Cupid or Dwarf Sweet Peas grow 5 to 6 inches in height; full-sized flowers; profuse bloomers. Excellent for borders. All the best colors and shades mixed. Pkt., 10c; 3 pkts., 20c; oz., 35c.
LAVENDER KING. A wonderful variety of rich true MAROON PRINCE. Rich maroon. By far the finest arly variety of its color.

RISING SUN. Rose-pink on cream. A bright and most SNOWSTORM IMPROVED. The best early white.

SWEET BRIAR. Lovely light pink with a soft salmon mer suffusion.

ZVOLANEK'S ROSE. The best deep pink.

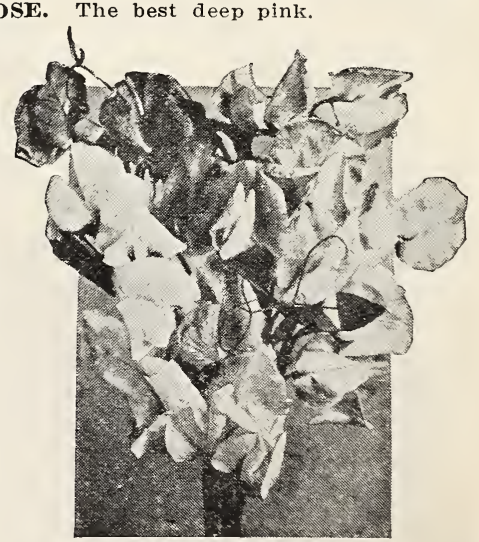

Cupid or Dwarf 


\section{Stocks}

The stock is one of the most popular annuals, either for bedding or pot culture. For brilliancy and diversity of color, fragrance, profusion and duration of bloom it is unsurpassed.

Large-Flowering Double Dwarf Ten Weeks (A). The most satisfactory strain of stocks for all purposes. Extra large flowers. A fine mixture of colors, including white, rose, blood red, yellow, lilac, lavender, blue and purple. $\mathrm{Pk}$

\section{Stokesia Cyanea (Cornflower Aster)}

A beautiful hardy perennial plant, growing 18 to 24 inches high, bearing freely from early in June until September its handsome cornflower-like lavender blossoms, which measure from 4 to 5 inches across. It is of the easiest culture, succeeding in any open sunny position, and not only is it desirable as a single plant in the hardy border, but it can also be used with fine effect in masses or beds of any size; indispensable for cutting. Pkt., 10c.

\section{Sunflowers}

Double Chrysanthemum-Flowered (A). Rich golden-yellow: double as a Chrysanthemum and as large as a man's hat. 7 feet. Pkt., 10e; oz., 35e.

Red Sunflower (A). A unique and gorgeous novelty; plants grow branchingly, 3 to 4 feet high, and bloom freely. Flowers of different shades of red and red margined with yellow; ranging from 2 to 5 inches in diameter. Pkt., 10c; 3 pkts., 25c.

Iammoth Russian (A). The largest variety of Sunflower, single heads measuring 12 to 22 inches in diameter, and containing an immense quantity of seed, which is highly valued as a food for poultry, being one of the best egg producing foods known. Pkt., 10c; $1 / 4$ lb., 15c; lb., 35c.

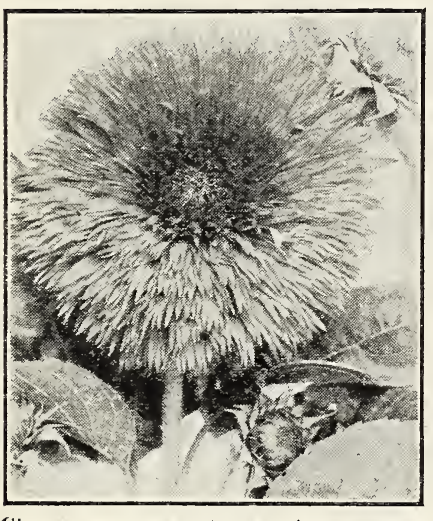

Chrysantnemum-riowered sunuwer

\section{Sweet Rocket (Hesperis)}

An old-fashioned perennial garden plant: also known as Dame's Voilet; grows from 2 to 3 feet high, and bears spikes of showy, fragrant flowers. Excellent for naturalizing among shrubbery or for planting in a permanent border; grand for cutting.

Lavender-Purple (P). Pkt., 5c. Plants 30c each.

White (P). Pkt., 5c. Plants 30c each.

\section{Sweet William}

Popular garden flower, showing a wonderful array of vivid colors in fancy patterns. Flowers are shaped, clustered and colored much like Phlox, the markings, however, being more sharply defined.

Perennial. Pink, white, scarlet and crimson shades, some with beautiful colored centers and borders, variegated, blended and suffused. A fine mixture of both delicate and gorgeous colors. Seed in mixed colors only. Pkt., 5c. Plants in mixture or separate colors of pink, scarlet and white, 30c each; 3 for $85 \mathbf{c}$; 12 for \$2.75.

Annual. The annual Sweet William is almost identical with the perennial varieties in form of flowers, rich and dainty coloring and fragrance, but unlike the perennials which do not bloom until the following year, these are annuals, blooming the same year the seed is sown. Pkt., 8c.

\section{Tritoma}

(RED-HOT POKER, FLAME FLOWER, or TORCH LILY)

Pfitzeri (Everblooming Red-hot Poker Plant) (P). The finest of all Tritomas. Grow 4 to 6 feet tall, the flowers measuring 12 to 15 inches long by 4 inches in diameter. They are dazzling scarlet, the lower half of the flower being tinged with rich orange. A clump makes a striking show, surpassing the finest Canna for attractiveness. Bloom August and September. If the roots are covered dưring the severe winter weather, they will live safely from year to year. Plants 35e each; 3 for $\$ \mathbf{1 . 0 0 .}$

Uvaria Grandiflora (P). Not as large as Pfitzeri and does not begin blooming quite as early in the season. Pkt., 10c; Plants 30e each.

\section{Valeriana (Garden Heliotrope)}

Showy, hardy border plants; producing large flower-heads of deliciously sweet spicy fragrance; June and July; $2 \frac{1 / 2}{2}$ to 3 feet. Fine for bouquets.

Red (P). Pkt., 8c; Plants 30e each.

White (P). Pkt., 8c. Plants 30c each.

\section{Veronica (Speedwell)}

Longifolia Blue (P). An elegant hardy border plant, growing 2 to 3 feet high; stout erect stems with intense deep blue flowers; fine for cutting. July and August. Pkt., 8c. Plants 35c each.

\section{Viola (Tufted Pansies)}

The improved forms of Viola Cornuta are rapidly growing in favor. They flower continuously for nearly eight months in the year, and while their flowers are not so large as those of the Pansy, their bright colors and continuous riot of bloom make them welcome additions to any garden. The seed we offer is of the choicest mixture. Pkt., 10c.

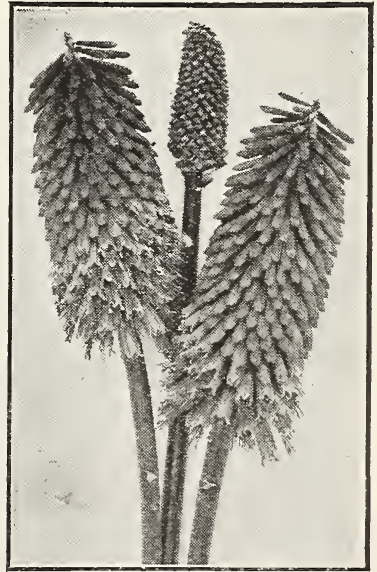

Tritoma 


\section{Verbenas}

Our strain of mammoth Verbenas has been carefully selected and improved until we can recommend it as the best procurable. The trusses and individual flowers are of large size, of brilliant colors, free-blooming and of vigorous habit. The Verbena is one of the most popular garden annuals and lends itself willingly to many uses. For beds, borders and window boxes it is particularly fine, and is frequently used for an undergrowth to tall plants like lilies, etc. The clusters of showy flowers are borne in constant succession from June until frost. We offer the following colors:

Blue (A). Pkt., 10c.

Purple (A). Pkt., 10c.

Scarlet (A), Pkt., 10c.
White (A). Pkt., 10c.

Yellow (A). Pkt., 10c.

Mixed Colors (A). Pkt., 10c.

SPECIAL OFFER-5 packets of mammoth Verbena-one of each of the five colors-for only 35c.

\section{LEMON VERBENA (H). A universal and well known favorite that} is grown principally for its fragrant lemon-scented foliage. It is a low growing tender plant with white fiowers; may be grown in the garden in the summer and in pots in winter. Its pale green delightfully scented

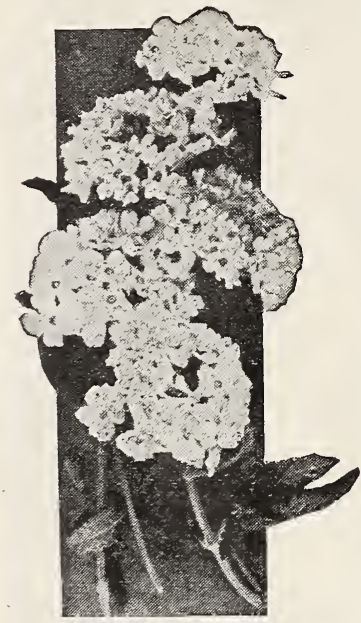

Perennial Verbena foliage is fine for bouquets and goes well with any flower; leaves may be dried and laid among linens. No seed to offer. Plants 30c each; 3 for 85c.

PERENNIAL VERBENA (P). One of the finest perennial bedding and border plants; a strong, thrifty grower, about 12 inches high and covered from early summer until late fall with a lavish profusion of handsome bright lavenderrose flowers. One of the most satisfactory low-growing perennial plants; a continual display of blooms; fine for cutting. No seed. Plants 35c each; 3 for 90c; 6 for $\$ 1.50 ; 12$ for $\$ 2.75$, postpaid.

\section{VINCA ROSEA (Periwinkle)}

Ornamental free-blooming plants, with dark, glossy, laurel like foliage and handsome pink and white flowers. One of the most satisfactory and long-flowering bedding plants we have. They can be taken up in the fall like Chrysanthemums, potted, and kept in bloom through the winter.

Pink. Pkt., 8c.

White. Pkt., 8c.

Mixed Colors. Pkt., 8c.

VARIEGATED VINCA $(\mathrm{H})$. A beautiful variegated trailing vine, admirably adapted for hanging baskets and vases. The leaves are a glossy green, broadly margined a creamy white; flowers blue. No seed. Plants 25e each; larger plants 40c; largest plants 60c each

\section{Virginia Stocks}

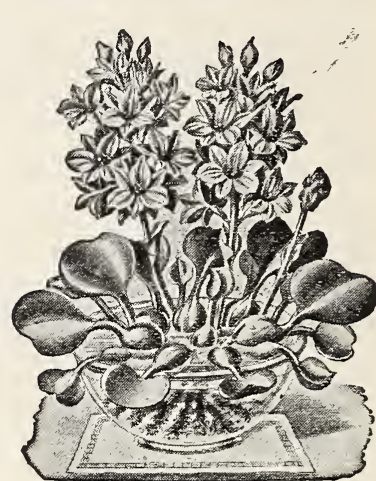

Water Hyacinth

Mixed (A). Early flowering hardy annuals that bloom between the spring and summer flowers, their bright colors in edgings and beds producing a charming effect. Pkt., 5c.

WALL FLOWER (B): Wallflowers should be better known. Their adaptability for pot culture and outdoor bedding and the exquisite fragrance of their flowers should win favor. The oriental coloring of the flowers in their rich reds and yellows is very effective. They are easily grown and last long as cut flowers. Not hardy in the Northern States, so should be taken into the house when fall frosts are expected, or wintered in cold frames. Pkt., 8c

WANDERING JEW (H). Foliage variegated purple, searlet, yellow and white; has been popular for many years, as a trailing, ornamental foliage plant. Used in hanging baskets, porch boxes, etc. Plants 20c each; 3 for 55c.

WATER HYACINTH (H). A beautiful

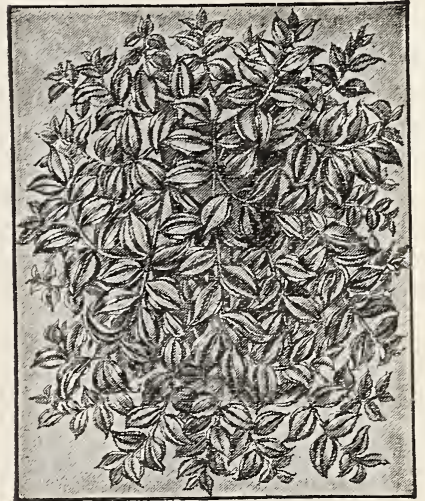
water plant forming a Iovely rosette of ghin ing green leaves and throwing up spikes of exquisite lilac-rose flowers resembling Hyacinth blooms. The most beautiful effect is produced by using a glass vessel of some sort with shells and white sand so arranged as to conceal the small amount of soil used. 35c each; 3 for $\$ 1.00$.

WILD CUCUMBER (A). This is the quick-

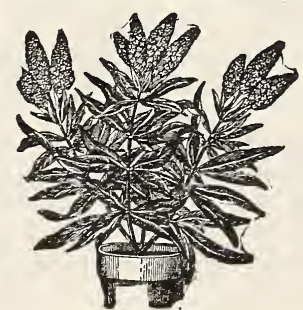

Lemon Verbena

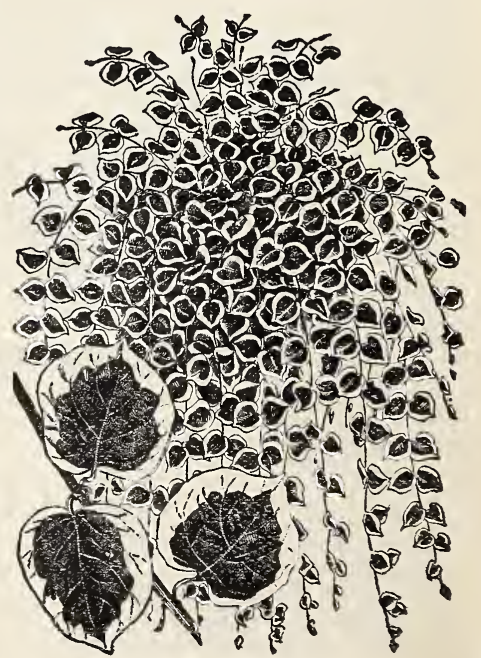

Variegated Vinca 


\section{Giant Dahlia-Flowered Zinnia}

This type, the latest development in Zinnias, bears flowers of mammoth size and in form like a perfect decorative Dahlia. The plant is a strong grower and flower stems are long and stiff. This remarkable variety includes a complete range of delicate, bright and rich colors from white, primrose, yellow, lavender and rose to orange, scarlet and crimson. A wonderful cut flower. Pkt., 15c: 2 pkts., 25c.

\section{New Curled and Crested Zinnia}

The petals are elegantly twisted and curled, giving the flower a most attractive appearance. The plant grows 18 inches high by 2 to $2 \frac{1}{2}$ feet in diameter, and blooms freely until killed by severe frost. The colors range from white through many shades of yellow, rose pink and salmon to deepest crimson. The new Curled and Crested is a grand cut flower which will last a considerable time in water. Pkt., 10c; 3 pkts., 25c.

Tall Double Zinnia (A). An extra select strain of fine double flowers of large size, but not equal to the Giant Dahlia-Flowered. Fine assortment of colors. Pkt., 5c.

\section{Dwarf Zinnias}

Dwarf Double Scarlet (A). Pretty little bushes; covered the entire season with a mass of perfectly double intense scarlet flowers. A most effective border plant, fine for bouquets. Pkt., 8c.

Double Dwarf Mixed (A). A fine mixture of all colors். Pkt., 8c.

\section{Pink Flowering Wax Plant}

The Pink Flowering Wax Plant is a handsome pot plant, especially fine for hanging baskets and suitable for rock work. It is of bushy growth; frosted waxy appearance; produces beautiful pink flowers, and almost always in bloom. A plant that is sure to please you. 35c each; 3 for 95 c.

\section{Genuine Oriental Flower Garden}

\section{Japanese and Chinese Novelties}

This is a special collection of Japanese and Chinese flower seeds; rare, scarce, curious, showy and most handsome varieties, entirely adapted to our climate. It is from Japan that we obtain many of our most beautiful flowers, such as Chrysanthemums, Irises, Lilies, Peonies, Oriental Poppies, etc., and many of our rarest, most curious, effective and showy varieties come from China. This Oriental Flower Garden contains a large assortment of varieties, all put up in one package. It would be expensive to buy them all in separate packets, as many of the varieties are very scarce, and not even offered by us in separate packets. Full directions for planting are sent with each package. This fine Oriental seed assortment will please you. Complete assortment (1 package) 10c; 3 for 25c.

\section{Perennial Flower Mixture}

\section{Varieties, $10 c$}

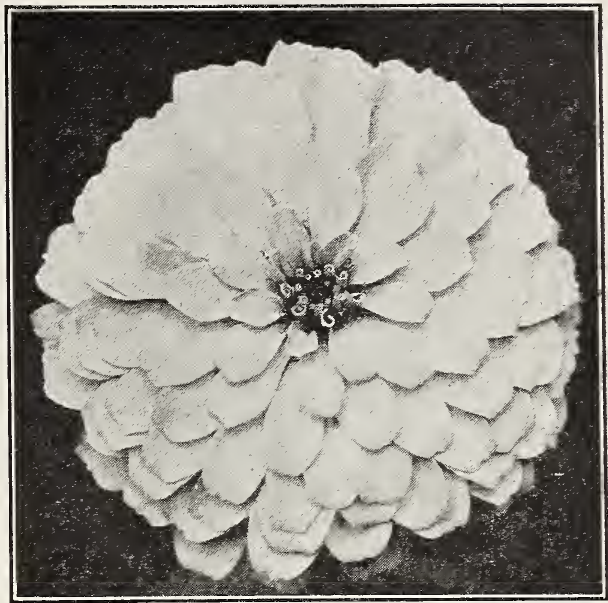

Giant Dahlia-Flowered Zinnia

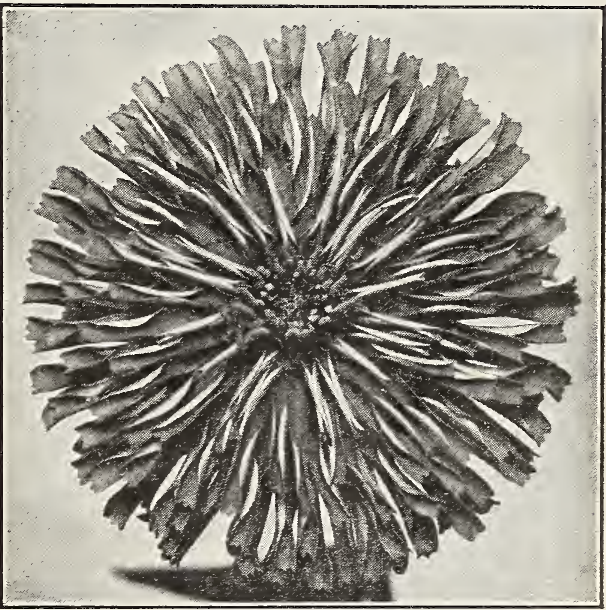

Curled and Crested Zinnia

Every garden should contain a good assortment of perennial plants, as they remain in the ground year after year and require very little care. An easy and inexpensive way of obtaining them is to send for our Perennial Flower Seed Package of 25 Varieties. Package, 10c; 3 for $25 \mathrm{c} ; 7$ for $50 \mathrm{c}$.

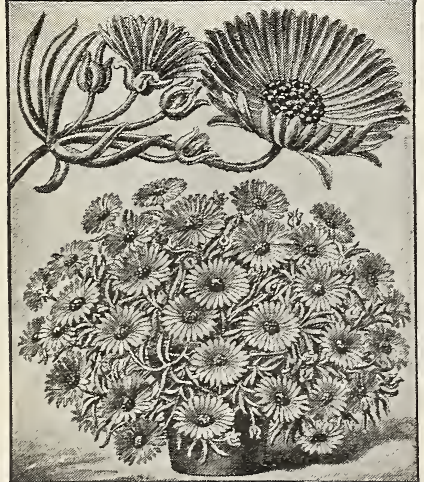

Pink Flowering Wax Plant

\section{Choice House Plants at Practically No Cost}

Tuberous-Rooted Begonia

Petunia, Giant Double Fringed

Carnation, Extra Choice

Double White Chrysanthemum

Double Yellow Chrysanthemum
Calla

Calceolaria

Cineraria

Cyclamen

Asparagus Fern
Fuchsia

Geranium

Gloxinia

Baby Rose

Lantana
The choice varieties of the above named plants are expensive, but we have a plan whereby you can secure a nice collection of the very choicest house plants at practically no cost. It is not necessary to pay enormous prices for these plants, for all of them can be grown from seed. Florists grow these plants from seed, and as soon as they are up and well rooted, sell them at high prices. You can grow them in the house easily and successfully, so there is no reason why you should not have as fine a collection of house plants as anyone in your community. We will send you our House Plant Seed Packet, containing a seed of all the above varieties, for only $25 \mathrm{c}$, which is less money than you would pay a florist for just one plant. Were you to buy these seeds in full-size separate packets, this assortment would cost you over $\$ 2.00$, as many varieties of house plant seeds are hard to get and very expensive. With each packet we send full directions for planting. We have a good stock of these seeds and expect to be able to supply all our customers, but should we run out of one or more of the varieties named, we reserve the right to substitute other choice varieties of equal value or return your money. We recommend ordering early. One packet of this assortment, $25 \mathrm{c} ; 5$ for $\$ 1.00$, postpaid. 


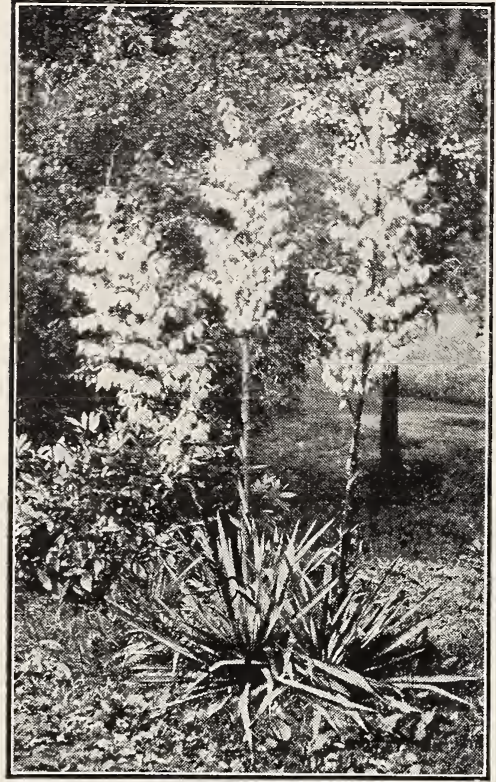

Yucca Filamentosa

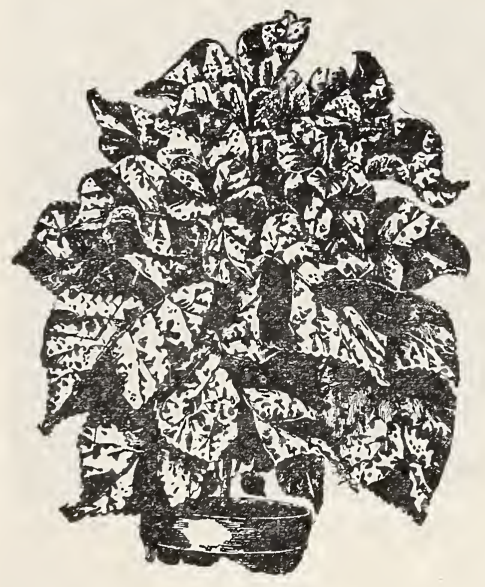

Acalypha

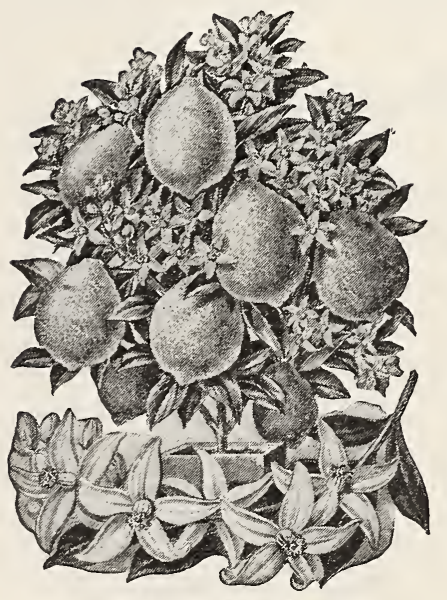

American Wonder Lemon

\section{Yucca Filamentosa}

Sometimes called Spanish Bayonet and Adam's Needle. A distinctive hardy evergreen plant producing large spikes of showy creamy-white flowers; 4 to 6 feet. Grows well on the poorest and driest sandy soils where little else will grow. 35e each; 3 for $\$ 1.00$.

\section{Resurrection Plant}

These peculiar plants are found among the pines and cedars of Palestine. When you get the plant it will have the appearance of a ball of tightly folded leaflets, dry and dead. Put it in water and it will open up its handsome fern-like foliage, turn green and begin to grow in about twenty minutes.

Take it out of the water and it curls up, turns brown and becomes dead again. It is capable of apparently dying and coming to life again repeatedly, and will keep in its dead or dormant state for years and reawaken directly upon being placed in water. It is an interesting, curious and most beautiful house plant with fine fern-like leaves of very agreeable fragrance. If you want a "table fern" that will prove satisfactory under all conditions, don't fail to get one of these marvels of plant life. Grows and thrives in a shallow bowl of water, and is greatly admired by everyone. 15c each; 2 for $25 c$.

\section{Fragrant Oleanders}

An immensely popular old-fashioned plant which can be grown in almost any soil or situation and kept growing all the year or can be allowed to rest in the cellar. The dark green willow-like foliage is in itself neat and pleasing. Large, double blossoms, as pretty and as fragrant as a rose. No plant makes a more handsome specimen for tub or pot culture for the house veranda or yard. Colors, pink, white, dark red and yellow. Plants 35c each.

\section{Acalypha}

The Acalypha, or Philippine Copper Plant is a most distinctive and valuable bedding or pot plant. Large and beautifully glazed, copper-colored foliage, with highly tri-colored blotches; of tropical appearance and nature, and grown as easily as Coleus. Plants $30 \mathrm{c}$ each; 3 for 85 c.

\section{American Wonder Lemon}

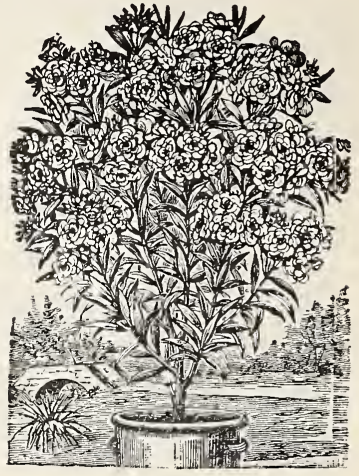

Oleander
A true everbearing Lemon that ean be as easily grown in a pot as a Geranium and which produces fruit weighing from one to three pounds each. These enormous fruits are borne on plants one to two feet high growing in pots; bear continually; delicious for lemonade and culinary purposes. Flowers are as fragrant as orange blossoms, which they somewhat resemble. The growth can be pruned to any size or shape; handsome as well as useful plants. Plants 30c each; larger plants 60c; largest size $\$ 1.00$.

\section{Dwarf Fruiting Orange}

A dwarf free-flowering variety which is suitable for pot culture. While it will grow 3 or 4 feet high and branch freely, it is not an uncommon thing to see little cutting plants five or six inches high full of bloom, and even bearing one or two medium sized oranges. The fruit at its best is not more than one-half the size of an ordinary orange, but it is very bright and beautiful in color and delicious in quality. Even though the fruits are fine, its beautiful flowers are what most strongly commend it for general cultivation. When it blooms it is so full that it seems to be all flowers. The pure, waxy white blossoms emit a delicate yet powerful fragrance which is surpassed by no other plant. Plants 30c each; larger plants 60c; largest size $\$ 1.00$.

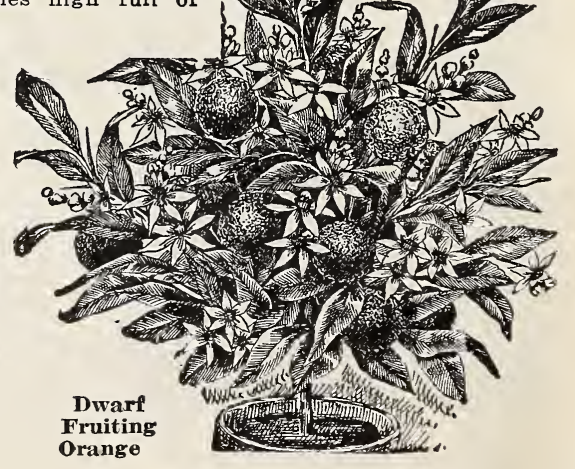




\section{Hedge Plants}

To screen unsightly objects from view and to mark lines or boundaries, bedges are most useful, and with proper attention are very ornamental, adding greatly to the appearance of any yard.

For permanent all-around effect evergreens are desirable, and the best sorts for the purpose are American Arbor Vitae and Norway Spruce. These can be allowed to grow at will or kept in any desired shape by shearing. For descriptions and prices of evergreens, see pages 68 and 69 .

Among deciduous shrubs for ornamental hedges the California Privet is very popular, having foliage of great beauty and permitting a shearing to an extent that would ruin most plants.

In the Northern States, California Privet is

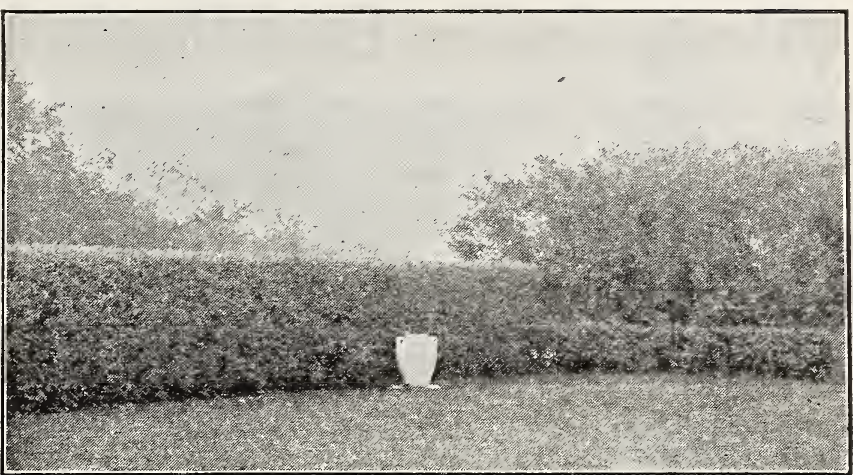

California Privet Hedge not as hardy as Ibota or Amour River Privet.

Ibota is the more bushy and makes the quicker growing hedge of the two hardy varieties. The Amour variety stands more erect.

If you want a low hedge that needs no trimming. Berberis Thunbergii (Japanese Barberry) is no doubt the most satisfactory of all. No other plant so fully meets every requirement of a hedge, combining beauty in all seasons,

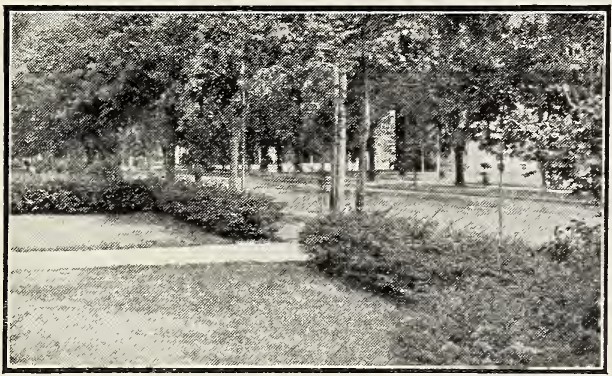

Berberis Thunbergii Hedge hardiness, compact growth, impenetrability and ease with which it may be kept in proper form.

For a screen or tall hedge, not to be trimmed, nothing surpasses Spirea Van Houttei (Bridal Wreath).

\section{Prices of Hedge Plants}

BERBERIS THUNBERGII. 25e each; \$2.00 per doz.; or 15o each in lots of 50 or more; delivered prepaid.

CALIFORNIA PRIVET. 13c each, by express, not prepaid. Order in multiples of ten and in quantities of 50 or more; no order for less than 50 accepted.

AMOUR RIVER PRIVET. 20c each, by express, not prepaid. Order in multiples of ten and in quantities of 50 or more; no order for less than 50 accepted.

IBOTA PRIVET. 20c each, by express, not prepaid. Order in multiples of ten and in quantities of 50 or more; no order for less than 50 accepted.

SPIREA VAN HOUTTEI. 25c each; 10 for $\$ 1.00 ; 25$ for \$2.25; or $8 \mathbf{c}$ each in lots of 50 or more; delivered prepaid.

\section{Dracena Terminalis}

A superb species with rich crimson foliage, so marked with carmine-pink and creamy-white that words cannot describe the exquisite coloring. It is a rapid grower, and for room adornment or as a vase plant for outdoor use it is indispensable. Strong plants 5̃c each; large plants $\$ 1.00$.

\section{Kentia Palm}

Kentia Relmoreana $(H)$. The best of the Palm family. It has fan-shaped, deeply split, glossy green leaves; the grace and lightness of the Cocos, but robust in growth and heavy in foliage. Plants 60e each.

\section{Giant Hyacinth}

Hyacinthus Candican. A species of Hyacinth which blooms late in the summer, growing 3 to 5 feet high: spikes of pure white flowers 2 fet in length. Large blooming size bulbs. 25e each; 3 for 60 c; 12 for $\$ 2.00$, postpaid.

\section{Fragrant Double Violets}

Bold, fine flowers; very prolific. The color is of a dark blue; flowers double. This is the favorite double blue Violet you see in the florists windows. Plants 35c each; 3 for $\$ 1.00 ; 12$ for $\$ 3.00$, postpaid.

A SATISFIED CUSTOMER FROM INDIANA-"The seed and plants I purchased from you last season were all that you claimed for them and more. The Dahlias from seed were a great surprise. I had 2 that were over 8 inches in diameter."-John Banks, Marion, Ind.

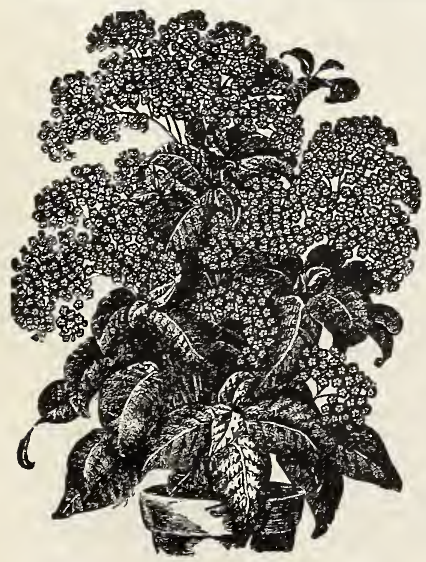

Giant Heliotrope Midnight

\section{Giant Heliotrope}

These are universal favorites on account of their delightful fragrance. Flower equally well as bedding plants in summer or as pot plants during the winter.

SWEET SCENTED MIDNIGHT. New giant-flowered, wonderful Heliotrope; darkest lavender. 25c each.

CZARINA. A beautiful new dark Heliotrope of exceptional qualities. 25c each.

MAD. DeBLoNaY. Large trusses of pure white flowers 25c each.

FLOR E N CE NIGHTINGALE. Flowers bright lavender. 25e each.

SPECIAL OFFER - One each of the above four Heliotropes, 90c.

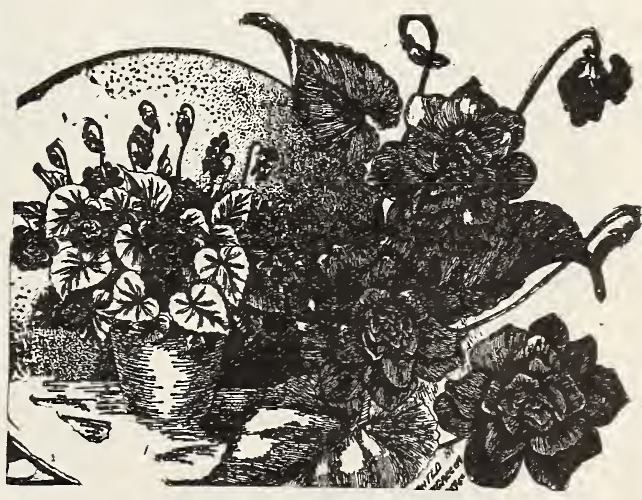

Fragrant Double Violets 


\section{Bargains in Bedding and House Plants}

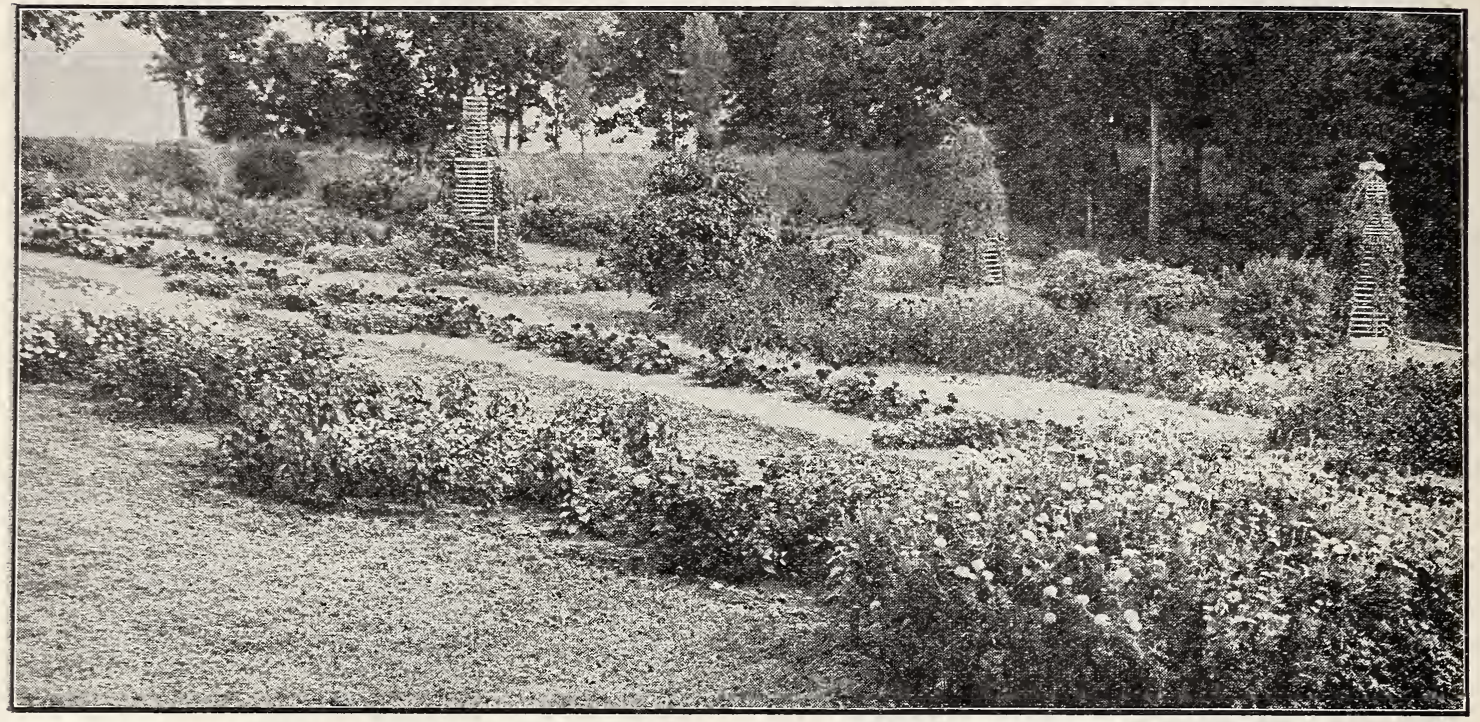

\section{Plants Offered in this Collection Will Give Satisfaction and Merit Further Orders}

The choice of varieties in these sets must be left entirely to us, as we cannot afford, at the collection prices to permit customers to select the varieties of plants that make up the different collections. Collections cannot be broken, divided,

C 5. 6 Prize Winning Chrysanthemums, all different.\$1.60

C. 5 Beautiful Geraniums, all colors...........95

C 7.6 Splendid Single Geraniums, fine varieties .... .72

C 9. 2 Double Geraniums, 2 Single Geraniums and

C 10. 1 Double Geranium: 1 Single Geranium, 1 Fragrant Geranium, 1 Ivy Geranium and 1 SilverLeaved Geranium

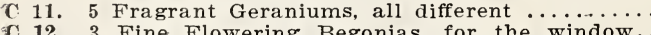

C 12. 3 Fine Flowering Begonias, for the window..

C 13. 6 Vines and Plants for a window basket $\ldots \ldots .$.
C 15. 6 Giant Petunias, never out of flower ..........8.

c 20. 12 Choice Double and Single Geraniums; will

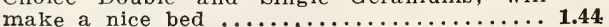

C 21. 4 Double Geraniums, 4 Single Geraniums, 2 Sweet Scented Geranuims and 1 Ivy Ger- 1.32

C 22. 3 Double Geraniums, 3 Single Geraniums, 3 2. 3 Deranium.... 1.20 C 23. 2 Silver-Leaved Geraniums, 2 Double Geraniums, 2 Single Geraniums, 2 Fragrant Gera- 1.20

C 24. 12 Chrysanthemums of the new large flowered $\mathbf{1 . 4 4}$ C 26. 12 Coleus, the best and most distinct varieties... 1.46 C 2\%. 10 Fuchsias, double and single, for window

3 gus Plumosus or Lace Fern ..............20 C 36. 15 Geraniums, double and French Oriole $\ldots \ldots \ldots$

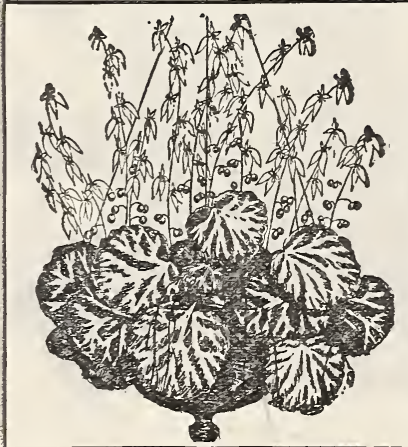

STRAWBERRY GERANIUM

One of the most beautiful plants imaginable: a many colors. leaves are nearly round, and striped f $\mathrm{ree}$ l y with silver bands; blooms white, of great beauty and borne in spikes nearly 12 inches high. The plant is of easiest growth; will stand neglect and mistreatment; adapted for vases, etc 35 c

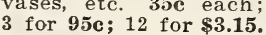

C 37. 15 Verbenas, all colors; will make a beautiful

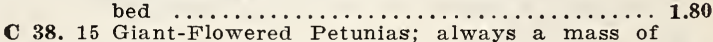
bloom ............................... C 39. 15 Fragrant Heliotropes, different shades ..... 2.70 C 40. 15 Highly colored Coleus; a fine bed ......... 1.80 C 41. 15 Lantanas, in variety; for pots, beds or boxes 2.70

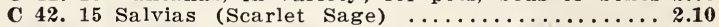
C 44. 15 Hibiscus; choice, large flowered sorts ...... 2.40

C 47. 20 Chrysanthemums; Japanese, Chinese and C 49. 20 Geraniums, Verbenas, Coleus and Heliotropes. 2.40 C 50. 20 Coleus, Heliotropes, Verbenas, Lantanas and Feverfews; fine for porch box or bed ..... 2.40

C 51. 20 Geraniums, Fuchsias, Coleus and Begonias.. 2.40

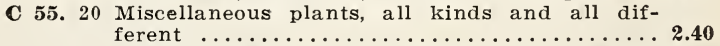
C 75. 10 Giant Flowered Snapdragons; red, white

Porch Box Collection No. 1

Twelve plants, all different, our selection from Salvias, Wandering Jew, Ostrich Fern, Boston Fern, Vincas, Ivy Geraniums, Coleus, Petunias, Begonias, Verbenas, Gera-
niums. Asparagus Sprengeri, Hibiscus, etc. Price \$1.68.

Porch Box Collection No. 2

For box 8 inches wide by 3 feet long; 16 plants our selection, \$2.20.

\section{SURPRISE OFFER}

After Season Sales At the end of our erally have surplus of all kinds of plants, and rather than carry this stock over, we hold a clearance sale beginning June 1st, and make up surplus collections miscellaneous plants at $\$ \mathbf{1 . 5 0}$ per collection: or $\$ 7.60$ for six collections. In these $\$ 1.50$ collections, we give several dollars worth of plants. All must be strictly our selection. Orders accepted any time before June 1st, and delivery will be made as soon after June 1st as possible.

"My order has been received in full, and everything in excellent condition. I had nursery stock from three dif ferent nurseries this year. What I had from you reached me in the best condition of any. I am well pleased." 


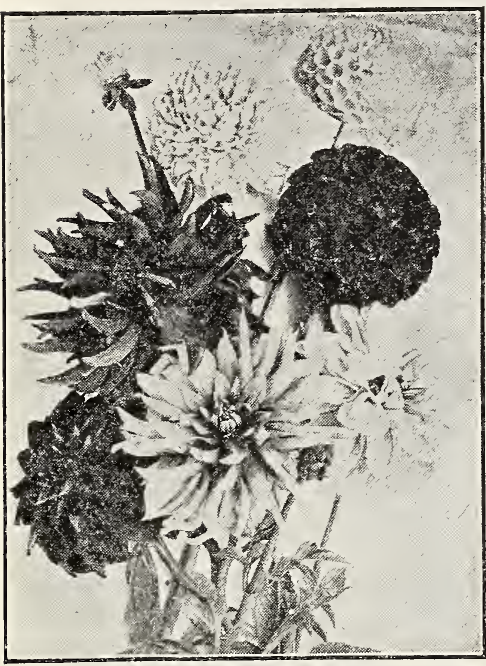

Dahlias

\section{A Bargain in Dahlias}

Large and Fancy Show Dahlias, Peony-Flowered Dahlias, Pompon Dahlias, Cactus Dahlias and Decorative Dahlias.

These assortments of Dahlias are made up from the finest varieties of the above types, the leading new sorts and the best of the older ones. White, Fire Red, Wine Red, Maroon, Crimson, Scarlet, Salmon, Orange, Cream, Buff, Canary Yellow, Sheli Pink, Lilac Pink, Deep Pink, Apricot, Purple, Lavender, Mottled, Variegated, Blended and Suffused. The tubers we send out are strong, vigorous and sure to bloom. This is your opportunity to secure Dahlias that are worth from $25 \mathrm{c}$ to $\$ 1.00$ each at the bargain price of 6 for $\$ 1.00 ; 10$ for $\$ 1.50 ; 24$ for $\$ 3.00$, postpaid.

\section{GLADIOLUS-Prize Collection}

This collection is made up of extra select varieties of the new improved type of Gladiolus and a few of the best of the older sorts. You will find it the most gorgleous, brilliant and beautiful collection you have ever seen; can in no way be compared with the kinds seen in the ordinary flower garden. They will grow and bloom for anyone, in any soil and climate; bloom more than any other spring pianting bulbs and require but little care. They are unequaled for cutting-last two weeks in water-and start blooming in early summer. Long graceful spikes, 18 to 20 flowers on a spike, single blossoms measuring 4 to 7 inches across, and from 2 to 4 spikes from each bulb. The Gladiolus is the queen of all flowers. This is an exceptionally big bargainrare collection of gorgeous and beautiful colors-all fine large bulbs. One dozen, 60c; 2 doz., \$1.00; 50 for \$2.00, postpaid. By express not prepaid, \$2.75 per $100 ; \$ 13.00$ per 500 ; or $\$ 25.00$ per 1,000 .

\section{CANNAS}

EUREKA. White flowers; rich green foliage. A beautiful variety. Height, 4 feet. 30c each; \$2.\%5 per doz., postpaid.

HUNGARIA. Flowers of purest pink with satiny sheen, like the color of a Paul Neyron Rose; green foliage. $3 \frac{112}{2}$ feet. 30c each; $\$ 2.75$ per doz, postpaid.

KATE GRAY. One of the finest Orchid-Flowered s o r t s. Sof $t$ orange, suffused with cardinal and carmine shades and with dotted yellow throat; green foliage. 5 feet. $25 \mathrm{c}$ each; $\$ 2.25$ per doz., postpaid.

KING HCMBERT. Immense heads of orange-scarlet, Orchid-like flowers measuring 6 to 8 inches across. Large heartshaped leaves of purple-madder-brown over bronze. Height, 5 feet. 25c each; \$2.25 per doz., postpaid.

LOUISLANA. Large Orchid-like flowers of vivid scarlet; foliage a glossy green, edged with purple. 7 feet. 25c each: $\$ 2.25$ per doz., postpaid.

MRS. A. F. CONARD. Exquisite salmon-pink flowers of the largest size; green foliage. 4 feet. 300 each; \$2.75 per doz., postpaid.

RICHARD WALLACE. Immense trusses of canary yellow flowers; bright green foliage. $4 \frac{1}{2}$ feet. 250 each; \$2.25 per doz., postpaid.

SHENANDOAH. Gorgeous, large trusses of pink flowers; foliage very beautiful, being of rich ruby red, exquisitely veined and tinted. $31 \frac{1}{2}$ feet. 30c each; $\$ 2.75$ per doz. postpaid.

THE PRESIDENT, Rich, glowing, cardinal scarlet blossoms of mammoth size; luxur1ant green foliage. One of the most gorgeous of all Cannas, 5 feet. 30c each ; \$2.75 per doz., postpaid.

VENUS. Soft rosy-pink with a pretty mottled border of yellow. $31 / 2$ feet. 25c each; \$2.25 per doz. postpaid.

WYOMING. Flowers a beautiful shade of deep orange; purple foliage. 7 feet. 25c each; \$2.25 per doz., postpaid. INING HUMBERT. YELLOW IKNG HUMBERT.
Heep rich yellow, marked with con trasting crimson dots; green foliage. Very showy. 5 feet, 250 each; \$2.25 per doz., postpaid.

SPECIAL OFFER

Twelve Cannas, one each of the above twelve kinds, for only \$2.50, postpaid.

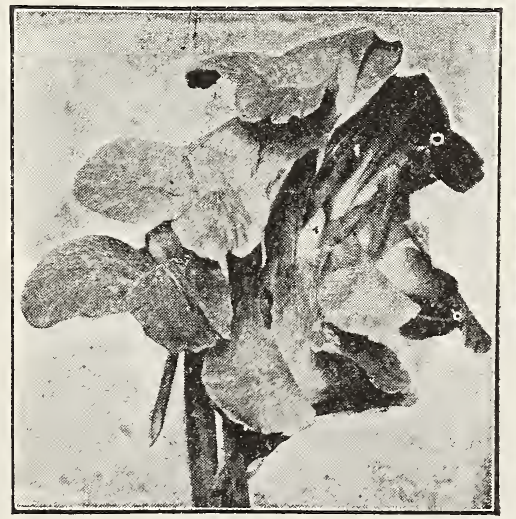

Yellow King Humbert Canns

\section{GLADIOLUS BARGAIN COLLECTION}

Smaller bulbs than the Prize Collection, but all blooming size. 12 for $40 \mathrm{c}$; 36 for $\$ 1.00 ; 80$ for $\$ 2.00$; 100 for \$2.40, postpaid. By express, not prepaid, $\$ 9.00$ per 500; $\$ 1 \% .00$ per 1,000 .

6 CANNAS, 6 DAHLIAS and 6 GLADIOLUS, all for \$2.00; 12 of each, \$3.75, postpaid. Special offer, for mixed colors only. A fine assortment that will please you.

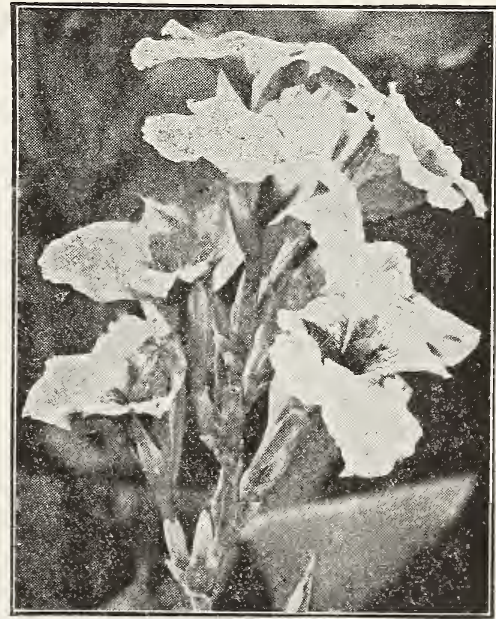

Mungaria Canna

\section{Prize Mixture of Cannas}

A fine assortment of varieties in mixture at $\$ 1.50$ PER DOZEN, POSTPAID. 


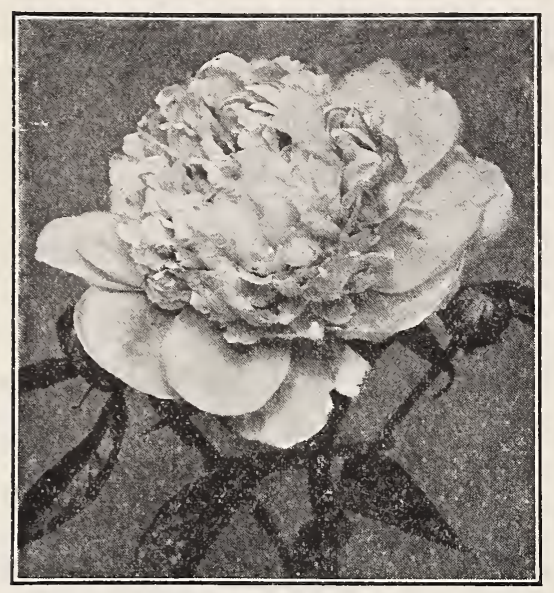

Mrons. Ju'es Elie

\section{Peonies}

Chinese Peonies are very desirable on account of their large size, fine colors and profuse blooming. They are perfectly hardy, and will succeed in any ground unless so wet the water stands on the surface in the winter and spring. May be planted either in the autumn or spring.

DUCHESS DE NEMOURS. Fine early white variety. Strong grower and free bloomer; large double flowers; very fragrant. 60c each, postpaid.

EDULIS SUPERBA. The famous Decoration Day Peony; earliest variety; very fragrant; of upright growth; and one of the best. Large double blossoms; beautiful pink. 60c each, postpaid.

FELLX CROUSSE. Very brilliant red; flowers mammoth in size, perfectly globular in shape, and have an agreeable fragrance. Mid-season. The best red Peony in existence. 90c each, postpaid.

LEONE. Buds bright pink; flowers shell pink, changing to creamy white when fully open. A large beautiful flower. 75c each, postpaid.

LOUIS VAN HOUTTEI. Rich deep crimson, with silvery tipped petals. Large round flowers; one of the best. 75e each, postpaid.

MLLE. VAILLANT. Outer petals creamy-white, blending to lemonyellow at the center. Very double and fragrant. 75c each, postpaid.

MONS. JULES ELIE. A fine shade of soft lilac-rose with silvery reflex. One of the finest and probably the largest flowered Peony. \$1.00 each, postpaid.

UNAMED PEONIES. Double White and Double Pink, 50c each; Double Red, 60c each. Three Peonies-one each of Red, Pink and White-for only $\$ 1.25$, postpaid.

\section{IRIS (Flower-de-luce)}

The Iris is one of the most beautiful of hardy garden plants. Will grow almost anywhere, in out-of-the-way corners, among shrubbery, etc., but for best results plant in a well drained sunny position, barely covering the roots. Avoid fresh manure in preparing the bed. They require very little care, and will remain in the ground from year to year.

CELESTE. Light blue. Large flowers, 30 inches.

FLAVESCENS. Center petals light primrose; outer petals cream and yellow. 30 in. HONORABILIS. Golden yellow center; outer petals rich mahogany and gold. 18 in. KOCHII. Center deep blue; outer petals rich velvety dark purple; buds black, 2 feet. LORELEY. Center light yellow; outer petals blue, bordered with cream. 30 inches. MME. CHEREU. Pure white, daintily edged with light blue. 3 feet.

MRS. H. DARWIN. White, with faint violet markings. Finest white. 2 feet.

PALLIDA DELMATICA. Enormous flowers of soft lavender; very fragrant. 4 feet. QUEEN OF MAY. Lovely soft lilac-pink. 30 inches.

FINE MIXED MRIS. Wonderful variety of colors, assorted, $\$ 1.00$ per doz.; 60c per half dozen, postpaid. PRICES All named varieties of Iris, 250 each; 6 for $\$ 1.10 ; 12$ for $\$ 2.00$,

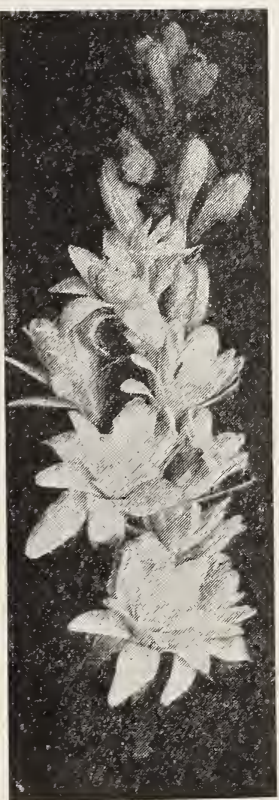

Tuberose

\section{Colchicum}

THE WONDER OF THE FLORAL KINGDOM. REQULRES NO SOIL, NO WATER, NO CARE

We know of no other flower as interesting. Beautiful rosy tinted blossoms, $1 \frac{1 / 2}{2}$ to 2 inches in diameter, that will bloom without soil, water or care. Through Nature's own process, Colchicum bulbs store within themselves all the fertility, water, etc., they require to bloom. You can put them in cold storage, in a dark cellar, pack them away in boxes, plant them in the ground, or set them on the dining room table. Outside of destroying them, it is impossible to keep them from blossoming at their regular blooming time, early in the fall. If allowed to bloom in the dark, however, the flowers are pale and not as attractive as if given sunlight. Simply place the bulb in a dish, bowl, saucer, or on the table or window sill and watch its beauty unfold. The blooms will keep in good condition for about two weeks, and when they fade and wilt, cut them off and others will follow in quick succession, each bulb producing from 6 to 15 flowers. When the blooming has ceased, the bulbs may be potted or planted in the open garden or lawn, where, the following spring they will develop a beautiful, broad, deep-colored foliage. You can remove the bulbs from the ground again about July first, dry them in darkness for a few weeks, and use for indoor decoration as at first. Orders for Colchicum bulbs are filled in August only, but to be sure of getting them, you should place your order as soon as possible, as our limited supply will probably all be sold before shipping time. Choice bulbs, 350 each; 3 for $\$ 1.00$, postpaid.

\section{Excelsior Pearl Tuberose}

EXCELSIOR PEARL is the finest of all Tuberoses. Spikes and blooms enormous in size and very double and fragrant. $10 \mathrm{c}$ each; 3 for $25 \mathrm{c} ; 12$ for $90 \mathrm{c}$, postpaid.

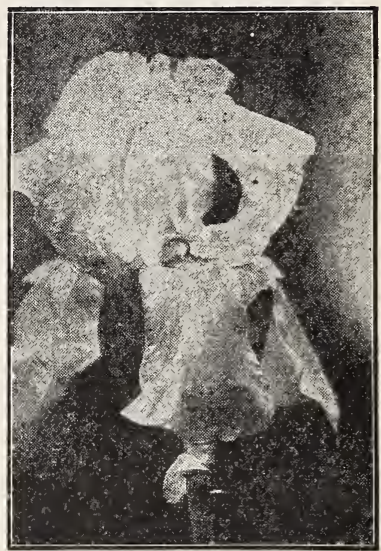

Mrs. H. Darwin Iris

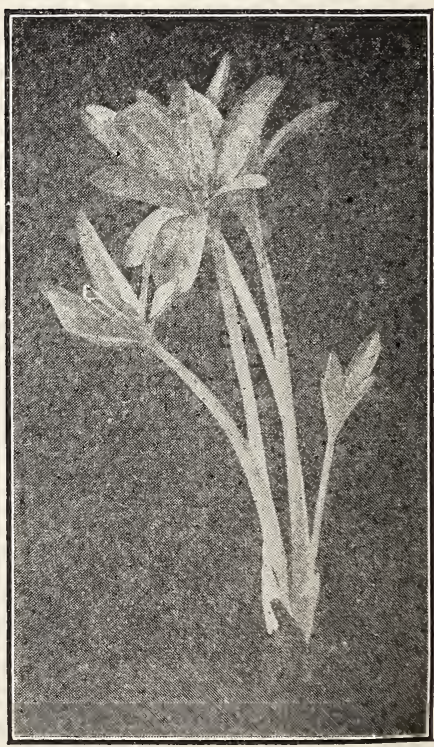

Colchicum 


\section{Hardy Lilies}

REGAL LILY (Myriophyllum). A recent introduction from North-western China and one of the most beautiful of all Lilies. The flowers are white, slightly suffused with pink; with a beautiful glow of canary yellow at center which continues part way up the trumpet. They are borne in clusters and measure 4 to 6 inches in length, and are nearly as broad. Its perfume is exquisite; not oppressive like some types, but with the sweet refreshment of the Jasmine. In the garden it blooms profusely during July, continuing its glorious display well into August. Not only is it one of the hardiest and finest outdoor Lilies, but it is the one kind, above all others, that we can recom mend to the amateur for forcing. 50c each; 3 for $\$ 1.40$, postpaid.

GOLD BANDED LILY OF JAPAN (Aurafum). Immense, fragrant flowers, measuring nearly a foot in width when fully expanded, are produced in great profusion from July to September. Broad petals, gracefully recurved. White, thickly studded with crimson-maroon spots, with a wide gold band down the center of each petal. Hardy. 350 each; 3 for $\$ 1.00$, postpaid.

RED BANDED LILY (Speciosum Rubrum). No words can overstate the brilliant beauty of this famous Japanese Lily. Large rosy-white flowers, thickly dotted with crimson spots. One of the best for garden culture. August and September. 35c each; 3 for \$1.00, postpaid.

GIANT TIGER LILY. A grand Lily with large pyramids of orange-red flowers spotted with purplish black. August and September. One of the hardiest and most easily grown. 35c each; 3 for $\$ 1.00$, postpaid.

DOUBLE TIGER LILY. A double form of the popular Tiger Lily. Flowers are borne in large clusters during August and September. Very hardy, permanent, easily grown and exceedingly beautiful. 35c each; 3 for $\$ 1.00$, postpaid.

EASTER LILY (Longiforum Giganteum). One of the most reliable and fragrant garden Lilies, bearing its beautiful, waxy, pure white trumpets in great abundance, during June and July. Flowers measure 4 to 6 inches in length and are almost as broad; borne in clusters of from 2 to 10 . The most popular Lily for forcing. 40c each; 3 for $\$ 1.10$, postpaid.

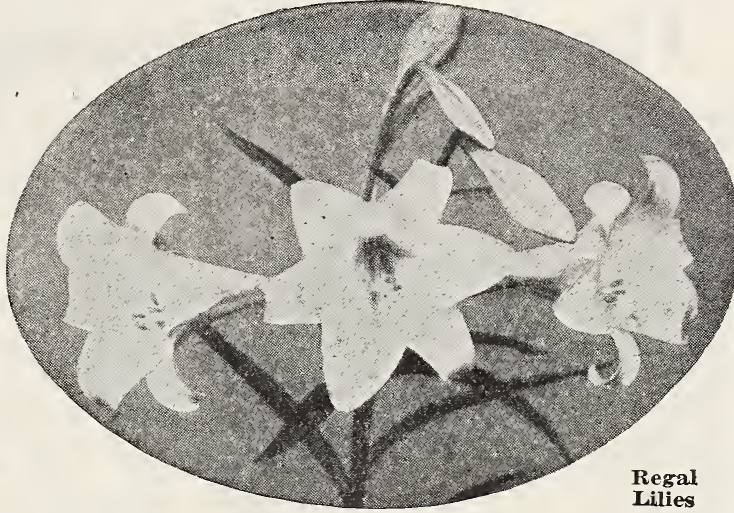

\section{Hardy Day Lilies}

BLUE PLANTALY LILY (Funkia). Attractive glossy Coliage of tropical appearance. Blue flowers. A fine edging plant to bind in a planting of taller perennials. One of the few choice perennials which will accept a shady location without protest. 35c each; 3 for $90 \mathrm{c} ; 12$ for $\$ 3.00$, postpaid.

LEMON LILY (Hemerocallis Flava). Beautiful lemonyellow flowers in July and August; 3 to 4 inches in diameter, and delightfully fragrant. 3 feet. 250 each; 3 for 60c; 12 for $\$ 2.00$, postpaid.

GOLDEN LILY (Hemerocallis Fulva). Rich orange color with darker shading. 4 to 5 feet. June and July. 20c each; 3 for 50c; 12 for $\$ 1.60$, postpaid.

\section{Oxalis Bulbs}

Fine for borders, pot culture, hanging baskets, vases, etc. White, pink, or Red, your choice of colors. 5c each; 250 per dozen; \$1.50 per 100; postpaid.

\section{BURGESS’ EVERGREEN LAWN MIXTURE}

Lawn trouble will be ended if you sow our Evergreen Lawn Mixture. If you want a beautiful lawn that will at all times be green and velvety, don't waste time and money sowing cheap grass seed. Our Evergreen Lawn Mixture is composed of the finest varieties of grasses, each of which has its season of beauty, with the result that a sod is produced that is always green. It will produce a rich and enduring turf in the shortest possible time without the use of cheap "quick growing" grasses. Not only is our Evergreen Lawn Mixture the best lawn mixture obtainable, but in the end it is really the most economical brand to plant. Being free from chaff, and of high germination, one pound will sow 400 square feet, Prices: 1/2 lb., 35c; lb. 60c; 3 lbs., \$1.65; 5 lbs., \$2.65, postpaid.

\section{Burgess' Shady Nook Lawn Mixture}

On nearly every lawn there are unsightly spots caused by the fact that ordinary varieties of grasses used for lawns do not do well in the shade. Our Shady Nook Mixture is made up of the most expensive fancy grasses which naturally grow in shady spots Prices: 1/2 Ib., 40c; lb., 70c; 3 lbs., $\$ 1.95$; 5 lbs., $\$ 3.00$, postpaid.

\section{White Clover for Lawns}

We have an Extra Fancy Dwarf White Clover that is especially fine for sowing with lawn grass mixtures. This variety will retain its green appearance throughout the hottest summer, and forms a close herbage which blends with the other grasses. For this purpose we recommend one ounce to each pound of grass seed. Pkt. (about one ounce), 10c; $1 / 4$ lb., 25c; $1 / 2$ lb., 45c; lb., 85c, postpaid.

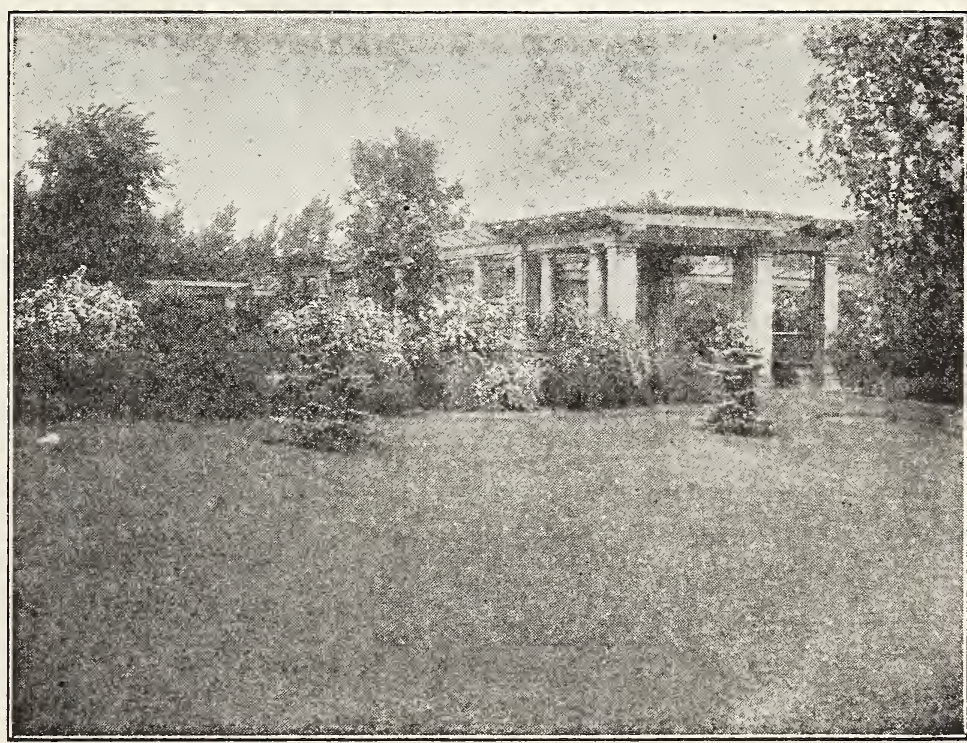

Wholesale Prices

For Wholesale Prices of lawn grass seeds, express, not prepaid, see page 76 


\section{Hardy Everblooming Hybrid-Tea Roses}

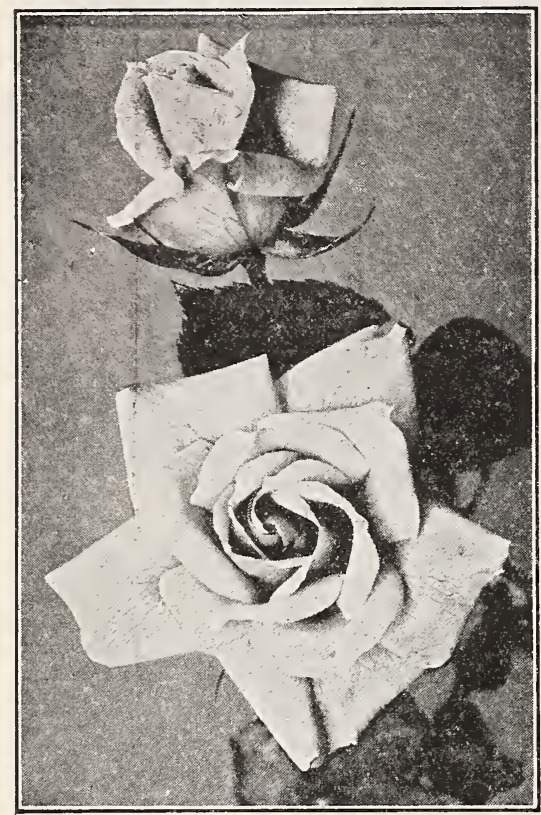

Bessie Brown

Without question, the most popular roses today, superseding all other classes for general planting. These roses are the result of crossing the tender everblooming Tea Roses with the hardy Hybrid Perpetuals or "June Roses." These roses are hardy and of vigorous growth, but should be given winter protection in the Northern States. They have the size of flower and exquisite fragrance of the "June Rose," combined with the constant blooming qualities, delicate tints and rich bright colors of the "Tea" or Monthly Blooming Roses. In other words, they inherit the good points of both the Teas and Hybrid Perpetuals, and blooin continually from the beginning of summer until fall frosts set in. Both our first size one-year and our two-year old plants, set out this spring, will bloom this year. The two-year old plants should have an abundance of roses throughout the entire summer.

AMELIA GUDE. A cross between Columbia and Sunburst. A charmingly beautiful yellow rose, outer petals reflexing deep yellow, center shading to cream. Buds long and pointed; very fragrant. First size plants, 45c each; 2 year, \$1.10, postpaid.

AUGUSTA VICTORIA. One of the most beautiful everblooming hardy garden roses. A continuous bloomer, producing successive crops of buds, formed with large petals of best substance, and show no center when fully open. Color, pure white, lightly tinted with lemon toward the center.

BESSIE BROWN. Blooms are very large, full double and of perfect shape; slender pointed buds with large shell-shaped petals. Color, creamy white, flushed and tinged with pink.

COLUMBIA. A glorious new rose that blooms all the time, almost thornless and thrives in any location. Wonderful strong shoots four feet or more in length, each producing a magnificent bloom, often measuring six inches across. Color a deep peach pink, deepening into a glowing pink. The fragrance is beyond description, sweeter than the American Beauty. One of the most exquisite roses we have ever seen. First size pilants, 400 each; 2 year, $\$ 1.00$, postpaid.

ETOTLE DE FRANCE (The Gold Medal Rose of France). This rose has been selected from the unlimited number of hardy roses as the acme of perfection. A brilliant shade of rich velvety crimson. Very striking. Flowers are extremely large, on long stiff stems, and buds are long and pointed.

FRANCIS SCOTT KEY. Rich glowing scarlet with darker shadings. Buds long and pointed, opening full and double; on long, upright stems. Strong healthy grower. Free blooming. There is nothing finer than this glorious rose.

GOLDEN OPHELIA. Bright golden yellow, paling slightly at outer petals. A seedling from the celebrated Ophelia, and a wonderful rose. First size plants, 35c each; 2 year, $75 c$, postpaid.

GORGEOUS. One of the most striking roses in existence owing to the marvelous blending of colors. Deep orangeyellow and heavily veined with reddish copper, the most charming and gorgeous coloring which has yet been attained in a rose. Awarded Gold Medal by the National Rose Society. Flowers large and full, exquisitely formed and produced in marvelous profusion. First size plants, 35c each; 2 year, 75c, postpaid.

HADLEY. Deep velvety crimson, retaining its brilliancy at all seasons of the year. Flowers borne on long, stiff stems, well above the foliage. A valuable outdoor rose and an all-the-year-'round forcing variety. First size plants, 35e each; 2 year, $75 \mathrm{c}$, postpaid.

HOOSIER BEAUTY. Glowing crimson-scarlet with darker shadings; buds of good length and splendid shape; a texture like velvet; opening into a magnificent bloom of dazzling brilliancy; very fragrant. A strong and clean grower, producing stems 2 to 3 feet in length, with a bud on every shoot. First size plants, 35c each; 2 year, 75c, postpaid.

IRISH FIREFLAME. Old gold, coppery-yellow or deep maddery-orange, flamed with ruddy crimson, becoming fiery orange as the spiral bud develops, the intense and varying color gradations spontaneously conveying the impression of a flame of fire. Large, single flowers, strongly and deliciously tea-perfumed and never out of bloom. Gold Medal, National Rose Society.

JONKEER J. I. MOCK (Giant La France). Gigantic flowers on stiff erect stems. Long, pointed buds and very double, full flowers of deep imperial pink. Highly perfumed, and the largest of all Hardy Everblooming Roses.

KILLARNEY. Brilliant sparkling pink with large, pointedbuds, broad, wax-like petals with silvery edges.

IA FRANCE. Silvery-rose, with pink shades and satin-like petals of unsurpassable beauty.

IIRS. AARON WARD. Large, full and perfect flowers, borne without interruption all summer on rigid upright stems coppery orange in the bud, developing to golden orange in the open fiower. First size plants, 35c each; 2 year, 75c, postpaid.

OPHELIA. Brilliant salmon-flesh shaded with rose on outer edges of petals, with a heart of glowing peach-pink and orange, yellow blendings, all passing finally to lighter shades. Faultless form in bud and flower; erect habit, stiff, long stems; free and continuous in growth and bloom. First size plants, 35c each; 2 year, 75c, postpaid.

RADIANCE. No pen picture can do justice to this wonderful everblooming rose, which produces such loads of immense, double flowers, marvelous in their unusual coloring; a beautiful blending of shades of carmine rose with opal and coppery reflections, extremely brilliant in effect.

RED RADIANCE. One of the most foremost outdoor Everbloomers. Produces its beautiful flowers in an amazing. abundance; they are of splendid form and practically every flower opens perfectly. A magnificent shade of cerise-red, which does not fade, and gives a glorious warm coloring of exquisite beauty.

RHEA REID. Vivid scarlet-crimson; flowers large, bold and of splendid substance. As an all-around garden bush rose it has no superior.

SUNBURST. Orange-copper or golden-orange and golden-yellow, all intense shades, giving an extremely brilliant effect. A giant rose, long stems, long, pointed buds, vigorous, free and healthy, with splendid keeping qualities as a forcer anc also as an excellent bedder.

WHITE KILLARNEY. One of the most exquisite pure white roses.

\section{A Satisfied Customer from North Carolina}

"The Rose bushes arrived in fine condition. They are fine, healthy plants. Be assured if ever I need anything in your line $I$ will be glad to get it from you."

Mrs. R. Schafer, Mount Airy, N. C.
PRICES All Roses in this catalog, except where otherwise noted, first postpaid.

SPECIAL DISCOUNTS. Order 4 or more and deduct $10 \%$ discount: $15 \%$ discount if you order $8 ; 20 \%$ discount on $12 ; 30 \%$ on 20 or more All must be shipped to one address in order to get these discounts. Take your choice of varieties. You may assort your order to please yourself, and each plant will go to you prepaid and properly labeled as to variety. 


\section{Hybrid Perpetual or June Roses}

The Hybrid Perpetuals are the hardiest of all roses, and require but little care after onee planted. Perhaps the most valuable of all hardy bushes for permanent planting, as they will succeed anywhere. Great numbers of people living in the Northern States think they cannot grow Roses on account of the severe winters, but Roses can be grown in any climate, provided the right kinds are planted. We have listed below sturdy, vigorous kinds, suitable for the far North. They thrive in all sections of the country and bloom profusely and regularly at the usual time and intermittently throughout the summer months.

AMERICAN BEACTY. The famous rich glowing crimson Rose Flrst size plants, $40 \mathrm{c}$ each; 2 year, 85c, postpaid.

ANNA DE DIESBACH. A lovely shell pink; long pointed buds flowers very full and double; sweetly fragrant.

CAPTAIN CHRISTY. Delicate flesh-pink, deepening at center to rosy-crimson. Large double flowers; almost everblooming.

CAPTAIN HAYWARD. Bright scarlet, very vivid in summer and glowing in autumn. Large, full and bold, the outer petals finely reflexed, while the center petals stand up well, making a flower of striking beauty.

CLIO. One of the grandest roses in existence. Flowers flesh color, shaded in the center with rosy-pink.

DINSMORE. A general favorite on account of its vigor of growth, constant and prolific bloom, which begins early and continues all through the season. Flowers large, perfectly double; rich erimson scarlet.

GENERAL JACQUEMINOT. The premier hardy crimson rose Buds and flowers are considered models of perfection and its brilliant shining color is the standard by which other roses are judged. In fact, it is almost unequaled in beauty of form, brilliant intensity of color and elegant velvety richness.

GLOIRE LYONNAISE. As free blooming as a Hybrid Tea, with beautiful, large, pointed buds and immense flowers on strong, heavy stems; open flowers enormous, full, deep and double. Color rich, creamy white, passing to salmon-yellow. The nearest yellow Hybrid Perpetual Rose, and a grand one.

MADAME MASSON. Blooms nearly all the time, bearing numbers of large, full, double flowers of unusual beauty and wonderful fragrance; clear, bright rose; very attractive and striking.

MADAME PLANTIER. A large, double, pure white Rose that can be especially recommended for cemetery planting. A continuous bloomer.

MRS. JOHN LAING. A beauty in clear, bright, shining pink; immense full blooms on long, stiff stems; sweetly scented. One of the most dependable fall bloomers.

PAUL NEYRON. The largest rose ever produced, sometimes measuring six inches across. In color, it is a most beautiful clear rose pink and possesses delicious distinctive fragrance equal to that of the American Beauty. Strong, upright grower; large leathery foliage; and a most abundant bloomer.

PRINCE CAMILLE DE ROHAN. Universally known as "The Black Rose," owing to its very deep, velvety crimson color, passing to intense maroon, and shaded black; large handsome and fragrant blooms.

ULRICH BRUNNER. Makes immense blooms, almost as large as Paul Neyron. Color, bright cherry-red. Flowers are full and of exquisite shape.

WHITE AMERICAN BEAUTY (Frau Karl Druschki). This rose is renowned as the very highest type of its class and the best snow-white rose ever produced. A single plant produces hundreds of massive pure white flowers. The most cortinuous-flowering rose in this excellent class; long buds and immense, perfectly double flowers, 4 to 5 inches across, with waxlike petals and very durable.

\section{Eskimo Beauty, the Hardiest of all Roses}

These Roses grow where no others will. They were produced by crossing the hardy Rugosa Rose with the best of the double, everblooming varieties. Eskimo Beauties grow, thrive and bloom anywhere. They are ideal cold climate Roses. They will grow in the South and in the Middle West; they will stand the winters of Minnesota, Wisconsin and the Dakotas without protection. In hardiness and vigor they are kindred to the Fir and Spruce. They make dense, sturdy, compact bushes, 4 to 6 feet high, and of about the same breadth, and are very ornamental. Once planted they are permanent; no pruning or spraying; do well in the most trying places-seashore, mountains or anywhere. On account of the shapeliness of their growth and freedom from insects and disease, these Roses are especially valuable for use as lawn specimens, and will last for years and yield an abundance of large double, fragrant, colorful blooms-the most dependable Roses for very cold climates. That is why they are called Eskimo Beauties.

CONRAD F. MEYER. Splendid, large, elegantly formed buds and flowers, $31 / 2$ to 4 inches across and perfectly double. Color is clear silvery-rose; very attractive and intensely fragrant. First size plants, 35c each; 2 year, 70c, postpaid.

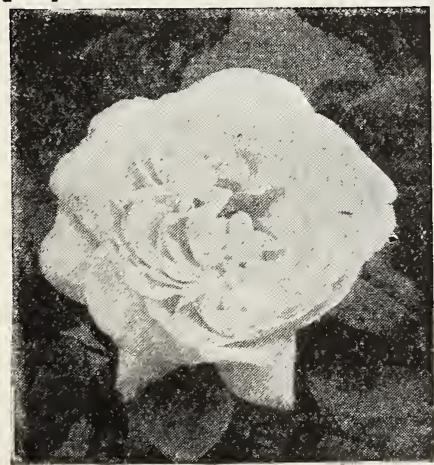

F. J. GROOTENDORST. A cross between Rugosa and Baby Rambler. Bright crimson flowers in clusters, resembling bouquets of red carnations. Blooms profusely from early summer until late fall. The finest of all Roses for hedges, and the only massing and hedging Rose that is hardy and everblooming. First size plants, roc each; 2 year, \$1.40, postpaid.

NEW CENTURY. Beautiful rosy-pink, in clusters of large, full and double flowers. First size plants, 35e each; 2 year, 70c, postpaid.

SIR THOMAS LIPTON. The best double white Rose in its class; beautiful and constant in bloom; of most vigorous habit, producing a bush 5 or 6 feet high, and as great in diameter. First size plants, 35c each; 2 year, r0c, postpaid.

\section{Hardy Moss Roses}

CRIMSON GLOBE. Deep crimson, large and full; nicely mossed.

MIOUSSELINE. Very large; double; pure white.

PRLNCESS ADELAIDE. Large; double; deep pink.

PRICES All Roses in this catalog, except where otherwise noted, first PRICES size one-year plants, 30c each; 2 year old plants, 65e each, postpaid. See pages 60 or 63 for SPECLAL DISCOUNT on orders for four or 


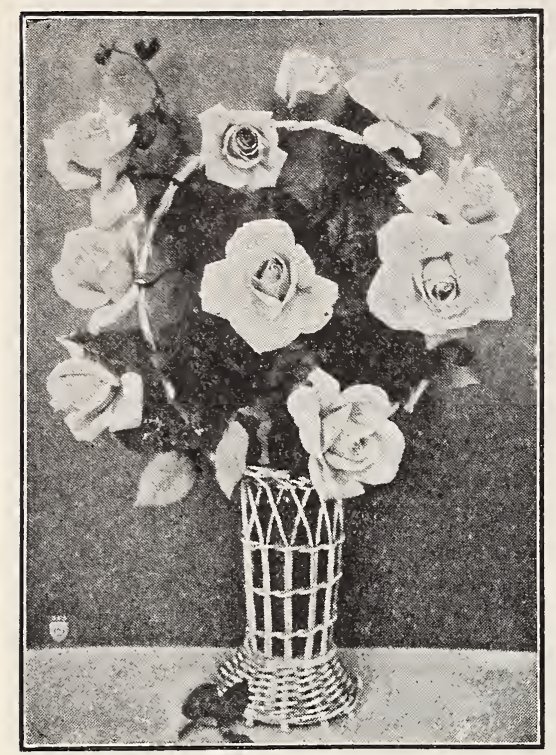

Tea Roses

\section{Choice Tea Roses}

While not so hardy as the Hybrid Teas, they will, with protection, live through the winter everywhere except in the extreme North. In the South they are unexcelled, whether planted in the open ground or used for pot culture. The facts that one year old plants produce a profusion of flowers makes them indispensable to every rose lover.

ALEXANDER HILL GRAY. The finest lemon yellow Tea Rose; does not fade; hardy. Awarded Gold Medal by the National Rose Society.

CHARLES DINGEE. Pronounced by some growers to be the most wonderful bush rose in the world. The flowers are immense in size, deep, double and grandly formed; rose tints in the center of the flower, gradually shading into pale blush creamy-white, producing a color effect found in no other rose.

LADY HULLINGDON, Deep apricot-yellow, shading to deep orange Gold Medal National Rose Society.

PINK MAMAN COCHET. The best Pink Tea Rose. Hardy everywhere.

WHITE MAMAN COCHET. The best white Tea Rose. Vigorous as an oak and hardy everywhere.

\section{Los Angeles Rose}

This Hybrid Austrian Brier Rose has created a sensation, taking highest awards here and abroad. An American production and worthy a place in every American garden. The color is the prized red and yellow combination; the petals bright pink, tinged with coral and shading to rich yellow at the base. The form of the flower is perfect and it does not open too promptly. The growth is exceptionally strong, throwing numerous sturdy, stiff branches that crown themselves with blooms of wondrous beauty. To those whose garden still lacks Los Angeles, we recommend it as one of the very finest of all Roses. First size plants, $75 \mathrm{c} ; 2$ year, $\$ 2.00$, postpaid.

\section{Gruss an Teplitz, the Great Hybrid China Rose}

This great Hybrid China Rose is one of the most useful of all roses for the lawn. Grows freely to a height of 4 or 5 feet; hardy in all sections; vivid, dazzling, fiery crimson; sweetly fragrant; and is in bloom all the time.

\section{Everblooming Climbing Roses}

These Roses are exact duplicates of the bush Roses of the same name except that they are vigorous climbers. For information regarding colors, etc., see description on this page and page 60 of the same varieties in bush form.

CLIMBING AUGUSTA VICTORIA

CLIMBING CECHLE BRUNNER

CLIMBING CLOTILDE SOUPERT

CLIMBING WTOILE DE FRA NCE

CLIMBING GRUSS AN TEPLITZ
CLIMBING KILLARNEY

CLIMBING OPHELIA. First size, 35c; 2 year, 75c.

CLMMANG PINK MAMAN COCHET

CLIMBING SUNBURST

CLIMBING WHITE MAMAN COCHET

\section{Hardy Polyantha or Baby Roses Bloom Profusely from June until Frost}

Border your flower beds or garden walks with these delightful Roses and have a continuous mass of bloom from early spring until after frosts. The most profuse bloomers of all Roses. The growth is rapid and symmetrical, although dwarf, which makes a most desirable combination for edgings and borders and are unsurpassed for cemetery planting. Being perfectly hardy, low in growth and continuous bloomers, they are taking the place of Geraniums and other bedding plants, for once planted they are there to stay and increase in beauty yearly.

BABY DOLL. The lovely little buds and blooms are of perfect form and finish and resemble miniature tea roses; brilliant golden yellow, tipped with clear, bright cerise. It is hard to understand how these plants, which are dwarf in size, can be so constantly loaded with flowers from spring until late fall, The fine, sharply pointed, glossy, deep green foliage is most beautiful for corsage and dainty florai work.

CHATILLON. Silvery crimson with whitish center. A handsome new variety.

CLOTILDE SOUPERT. One of the best of all bedding roses, producing clusters after clusters of the finest formed flowers; full and double and deliciously sweet. Color effect beautiful, ivory white, shading toward the center to silvery-rose.

IDEAL. Flowers borne in clusters, resembling blossoms of the Climbing Crimson Rambler. The best and brightest red Baby Rose.

KATHERINE ZEIMET (White Baby). Free bloomer of great masses of double pure white glistening flowers, which are delightfully fragrant.

PRICES All roses in this catalog, except where otherwise noted, first size one-year plants, 30c each; two-year old plants, 65c each, postpaid. See pages 60 and 63 for SPECLAL DISCOUN' on orders for four or more Rose plants.

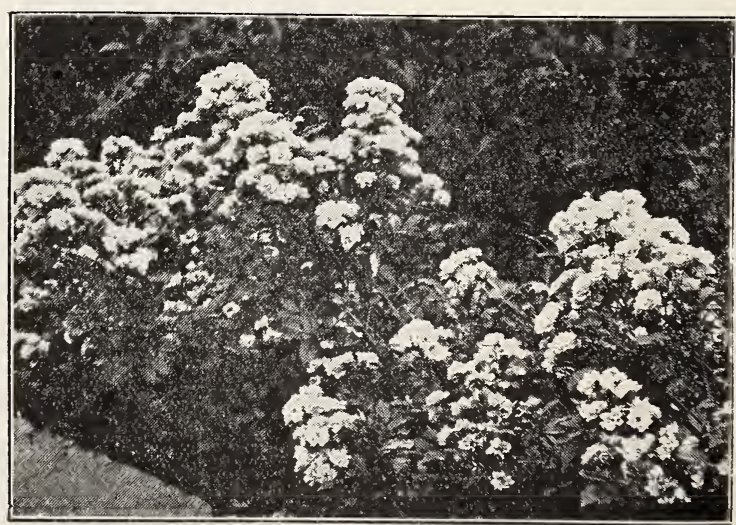




\section{Hardy Climbing Roses}

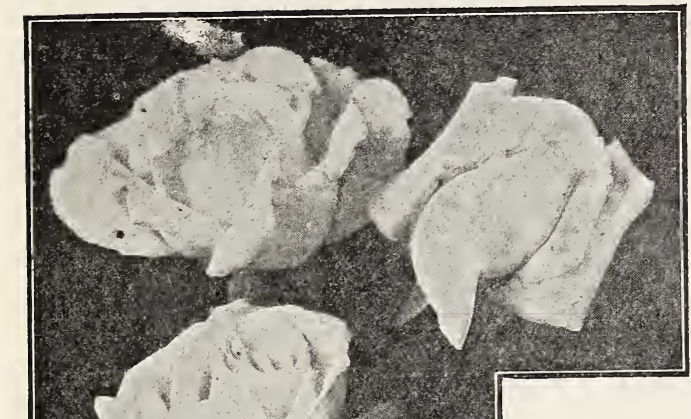

These Roses are necessary for the home, giving it a touch of beauty and calling forth more admiration than any other ornamental plants. They are used extensively for screening undesirable views of buildings and create most delightful and refreshing shade when used on porches, verandas, pillars and fences. All are hardy everywhere and require very little care and attention to produce an amazing profusion of exquisite hued blossoms.

ALIDA LOVETT. Bright shell pink with shadings of sulphur-yellow at the base of petals. Similar in size and form to Dr. Van Fleet.

BESS LOVETT. Clear, bright crimson, double, full, cupped, and of notable lasting quality. Resembles Climbing American Beauty, but is brighter in color and more fragrant.

CHRISTINE WRIGHT (Climbing Pink American Beauty). Very large, double flowers of exquisite wild-rose pink, produced on a strong and hardy plant of good habit. Blooms very early.

CLIMBING AMERICAN BEAUTY. A sturdy, vigorous grower, absolutely hardy, throwing strong flowering canes in one season which are covered with dark, glossy foliage that is immune to disease and insects. The Roses are 3 to 4 inches in diameter, are produced on individual stems, vivid rosy-crimson in color, and with the same delicious fragrance as the old American Beauty.

DR. VAN FLEET. No climbing Rose has created more favorable comment than Dr. Van Fleet, for the flowers are so perfect in every way-form, color, delicate fragrance-and borne on such long, strong stems. The splendid hearty growth, beautiful shining bronze-green foliage and perfect hardiness, added to the exquisite blooms, make this a most desirable variety. Open flowers are 4 inches and over in diameter with high-built center and beautifully undulated and cupped petals. The color is a remarkable delicate shade of flesh-pink on the outer surface, deepening to rosy-flesh in the center. You can expect several canes, 10 to 15 feet long, every season, and these canes will produce masses of roses the following June. Flowers full and double; stems. 12 to 18 inches long.

Climbing American Beauty

MARY LOVETT. The finest of all absolutely hardy white climbing roses. Could be appropriately described as a pure white Dr. Van Fleet.

MARY WALLACE. A Dr. Van Fleet production. This sensational Climbing Rose makes a strong upright bush with large shiny foliage, producing for weeks in the spring and also in the summer and fall, its large semi-double flowers, four inches across; color clear rose pink with salmon at the base of petals. Hardy everywhere. A very remarkable novelty. Is an advance over any of its kind we have yet had.

PAUL'S SCARLET CLIMBER. Expert rose growers agree that this is the best and most valuable climbing red rose for home planting. The full, double, scarlet flowers cover the entire bush in a solid vivid mass of flaming red, making a brilliant display for a long time. The petals do not fade like many climbing roses, but retain their bright color, and remain in bloom for from two to four weeks. This rose received the gold medal and cup for the best Climbing Rose at the National Rose Society's exhibit.

SILVER MOON. Blooms very large, 4 or more inches in diameter; pure white with large bunch of yellow stamens in the center; single and beautifully cupped, forming a clematis-like flower. A Satisfied Customer from Utah "Let me take this means, please, of expressing my gratification arrival. They came in perfect condition. I believe it is not very much Washingt pleased with your plants, and next spring will know where to place my business." J. L. Chatelain, 3772

\section{Rambler Roses}

You surely have a place for some of this class of climbing Roses. You can use them on porches, arbors, arches, pergolas, clothes-posts, fences and old stumps of trees. Hardy everywhere.

BLUE RAMBLER. Flowers rosy-lilac when opening and change to a metallic blue. Very showy.

DOROTHY PERKINS. The finest of all pink ramblers. Flowers perfectly double and borne in immense clusters.

GARDENIA. Pleasing yellow buds, turning white on opening.

RED DOROTHY PERKINS (Excelsa). The most popular red rambler. Flowers in large clusters of rich scarlet.

WHITE DOROTHY. A pure white sport of the well known Dorothy Perkins.

YELLOW RAMBLER. A grand variety, quite similar to the old Crimson Rambler, with the exception of color. Rich yellow flowers, borne in large clusters; blooms profusely, and is as hardy as an oak.

PRICES All Roses in this catalog, except where otherwise noted, PRICES first size one-year plants, 30c each; two-year old plants, 65c each, postpaid.

SPECIAL DISCOUNTS. $10 \%$ discount if you order 4 Rose plants; $15 \%$ if you order $8.20 \%$ discount on $12 ; 30 \%$ on 20 or more. All must be shipped to one address in order to get these discounts. Take your choice of varieties. You may assort your order to please yourself, and each plant will go to you prepaid and properly labeled as to variety.

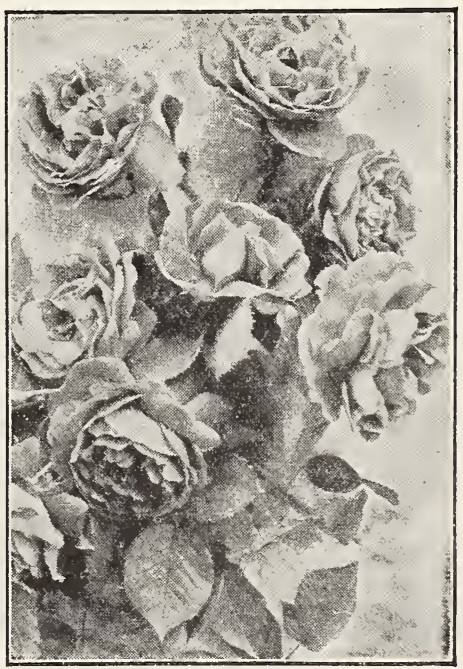

Yellow Ramblers 


\section{Ornamental and Flowering Shrubs}

A small amount of money spent on shrubbery will beautify your home and greatly increase the value of your property. We have a fine stock of thrifty field grown plants, that are sure to give the best of satisfaction.

(A) denotes shrubs which attain 1 to 3 feet in height at maturity; (B), 4 to 6 feet; (C), 7 to 9 feet; (D), 10 to 12 feet; and (E), over 12 feet.

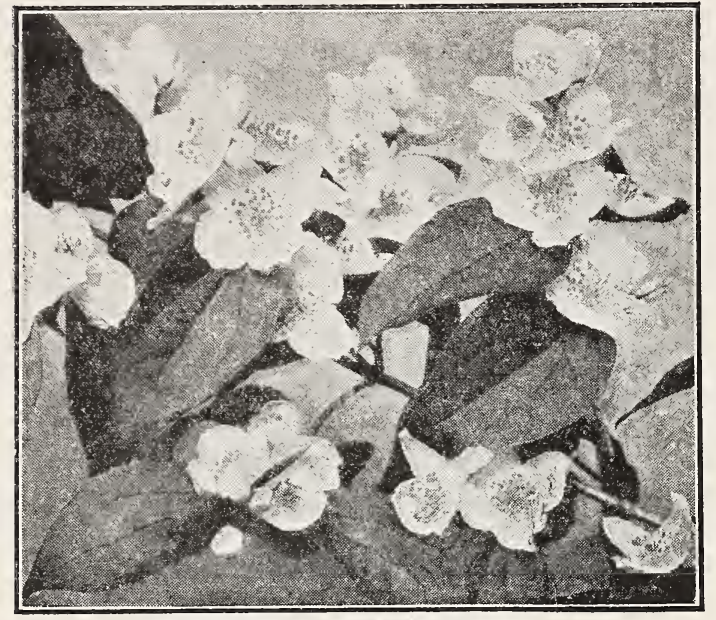

Philadelphus, Giant Flowered

ATWHEA (Rose of Sharon) (C). Flowers profusely in late sumorer and early fall, when few other shrubs are in bloom. Valuable for hedges or single specimens. We can supply eithers single or double flowered in the following colors.

iDouble Bhue. 35c each.

Double Pink. 35c each.

Double Red, 35c each; large size 50c.

Double White. 35c each; large size 50c.

Single Blue. 35c each.

Single Pink. 35c each; large size 50c.

Single Fed. 35c each; large size 50c.

Single White. 35c each; large size 50c.

AMORPHA (False Indigo) (C). Attractive blue flowers in Jume; feathery foliage. The finest blue flowered shrub. 45c each; large size 75c.

ARALIA SPINOSA. (E). Tall tree-like shrub of semitropical appearance. Broad, handsomely cut leaves, often 3 or 4 feet long, and huge clusters of small white flowers in July. 50c each; large size \$1.00.

BERBERIS THUNBERGII (Japanese Barberry) (B). Beautiful shrub of neat, dense growth, yet graceful because tof its drooping branches. Yellow flowers, followed by scarlet

berries through the fall and winter. Fine for planting along drives and walks, and as a hedge plant, it needs no trimming. 25c each. $\$ 2.00$ per dozen; or $15 \mathrm{c}$ each in lots of 50 or more. Large size, $40 \mathrm{c}$ each; $\$ 3.50$ per dozen; or $25 \mathrm{c}$ each in lots of 50 or more.

BUTTFRFLY BUSH (B). The most perpetual bloomer and one of the finest of all shrubs; flowers from early summer until frost, and blooms the first season. Beautiful lilac-colored flowers borne on flower heads which frequently measure 10 inches in length. Large 2 year old plants, 75c each.

CATICANTHUS FLORIDUS (Sweet Scented Shrub) (D). An interesting shrub, having a spicy, fragrant odor. Flowers of rare chocolate color; bloom in June and at intervals after. 40 cach.

CORNUS (Dogwood), Red Branched (C). Flowers creamy-white. Very conspicuous and ornamental in winter, when the bark is bright blood-red. $40 \mathrm{c}$ each; large size 75c.

Elegantissima Variegata (C). Purplish red branches and beautiful silvery variegated foliage. The most valuable variegated leaved shrub; capable of refined compact shape by pruning. A few of these set among the green-leaved slarubs produces a wonelerful effect. Beautiful both summer and winter. Large 2 year old plants, 90c each.

CYDONIA JAPONICA (Japanese Quinee) (C). Very ornamental. Double crimson flowers in great profusion early in the spring. $\mathbf{4 0 0}$ each.

DEUTZIA, Pride of Rochester (C). One of the most elegant shrubs ever produced. A vigorous grower and produces its hand.

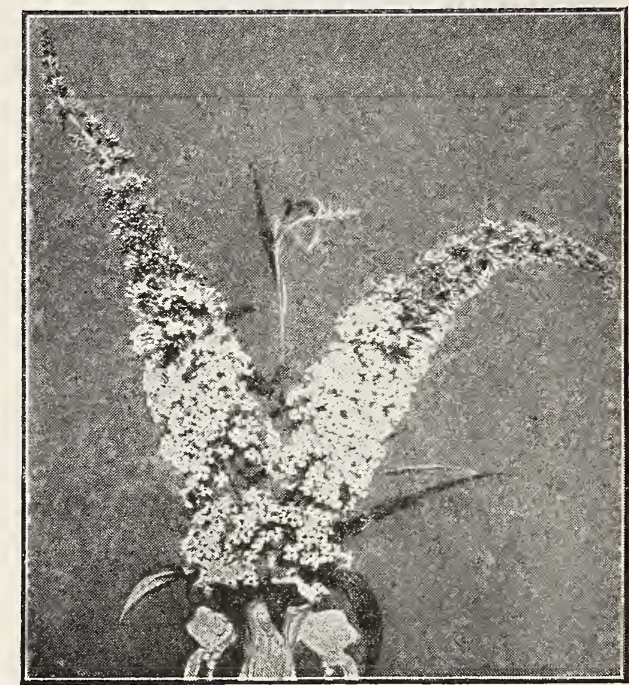

Butterfly Bush

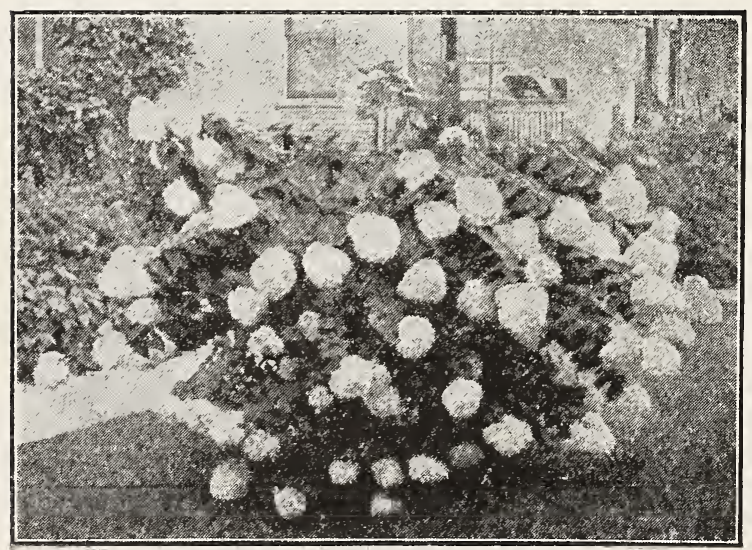

Hydrangea Paniculata Grandiflora some flowers in great profusion. Flowers white, with back of petals tinged rose; very double. 400 each; large size 75c.

Gracilis (A). One of the choicest dwarf shrubs.

Dense, bushy, and wreathed with pure white flowers in

May. Also valuable for winter blooming in pots. 50c each.

FORSYTHIA (Golden Bell), Fortuneii (C). Handsome shrub with golden yellow flowers that appear very early in the spring, before the leaves, frequently while the ground is still zovered with snow. Branches cut off in winter and put in a vase of water will bloom in the house. 35c each.

\section{All Shrubs Delivered Prepaid}

All Shrubs and Vines listed on pages 64,65 and 66 are hardy, FIELD GROWN STOCK, and not to be compared with the tender green house rooted plants of these varieties being offered at lower prices. You will notice we have two sizes of many of the varieties. The small size plants are one and two year old; the larger sizes are two, three and four years old.

All Shrubs and Vines DELIVERED, PREPAID, at prices given. 


\section{SHRUBBERY-Continued}

FORSYTHIA, Intermedia (C). Not so uppight in growth and more bushy than Fortuneii. Large plants, 50c each.

Suspensa (Weeping Forsythia) (C). Graceful, long, slender drooping branches. Very showy yellow flowers. One of the showiest shrubs in cultivation. 45e each; large size 75̃c.

FRINGE, Purple (Smoke Tree) (D). Conspicuous spreading shrub or small tree; overhung in mid-summer by mist-like clouds of tiny flowers. These billowing panicles of light lavender give the impression of smoke at a distance. One of the most beautiful of all large shrubs. Large two year old plants, $\$ 1.00$ each.

HONEYSUCKLE, Tartarian Pink (C). A large handsome bush. Loaded with pink flowers in the spring, followed by red berries during the summer and fall. 35̃e each.

Tartarian White (C). Same as Tartarian Pink, except color of flowers, which are pure white. 35e each.

Morrowii (Japanese Bush Honeysuckle) (B). A broad spreading bush; pure white flowers which change to yellow tones, followed by a multitude of bright red berries. 35̃ each.

HYDRANGEA, Hills of Snow (A). The earliest blooming variety. Flowers pure white, 50c each; large size, 75̃c.

Paniculata Grandiflora (C). One of the most magnificent hardy shrubs, bearing immense panicles of bloom a foot long, white at first, turning to rose in autumn. Commence blooming in August. Will bloom the same year they are set out. 50c each; large size, 75c.

LILAC, Persian Red (C). Very graceful. \%óc each.

Purple (C). Dense panicles of purple flowers. The most fragrant of any. 40e each; large size 60c.

White (C). Pure white; very fragrant. 50c each.

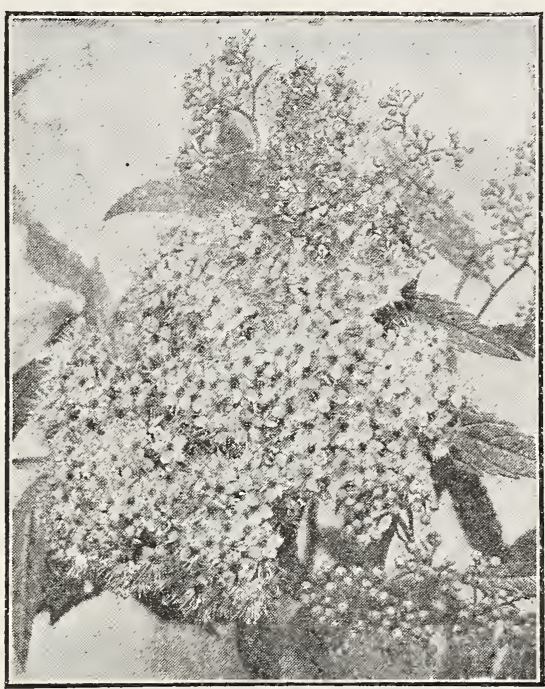

Spirea, Anthony Waterer

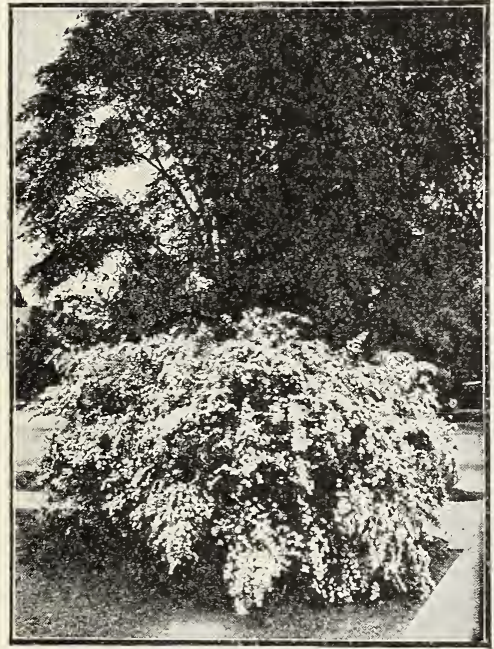

Spirea Van Houttei

PHILADETPFUS, (Syringa or Mock Orange) Giant Flowered (D). Tall vigorous grower with large foliage and flowers. Valuable for backgrounds, screens, grouping and specimens. Flowers white and very fragrant. Beautiful for cutting. 35c each; large size, 50c.

Virginalis (Double Syringa) (B). A magnificent new variety. The flowers are double and the largest, most handsome of any known variety: often measure two inches or more in diameter, very fragrant and excellent for cutting. It has a long blooming season, making its best display of flowers in May and June, and continues to blossom into the fall. One of the most desirable shrubs. Many who have seen it, declare it to be the most beautiful white flowered shrub that has been introduced within the last quarter of a century. Large two year old plants, $\$ 1.25$ each.

Aurea (Golden Syringa) (B). Golden-yellow foliage; white flowers. Valuable for grouping, and the best goloen leaved shrub. Three year old plants, \$1.00 each.

RHUS, Typhina Laciniata (Fern Leared Sumac) (D). Beautiful fern-like foliage of deep green, which, in the fall, turns to shades of golden yellow and brilliant red. Especially effective if placed in the rear of lower shrubs. Flowers are borne during June and July in dense terminal panicles, followed by red fruits which are attractive in the autumn and winter. Extremely hardy; will thrive in any soil, even in dry, barren spots where little else will grow. 50c each.

SNOWBALL (Viburnum Sterilis) (D). A well known favorite shrub with globular clusters of pure white flowers the latter part of May. 40c each.

SPIREA, Anthony Waterer (Perpetual Blooming Red) (A). Handsome round bushes, 3 feet high and wide. Begin to bloom in summer and continue until fall. Rose red flowers in large clusters all over the bush. 50c each.

Billardi (Perpetual Blooming Pink) (B). A grand shrub for planting in masses, and makes a good cut flower. Beautiful shade of pink. 40c each.

Van Houttei (C). A leader among shrubs, and a beautiful ornament at all seasons. Sometimes called Bridal Wreath. A round and graceful bush with arching branches, covered with white flowers in early summer. No doubt the most useful of all shrubs. 25̃e each; large size, $45 \mathrm{c}$.

Aurea (Golden Spirea) (C). Of similar habit to Spirea Van Houttei; golden yellow foliage. One of the finest yellow-leaved shrubs. 40c each; large size, 7óc.

\section{WE PAY EXPRESS CHARGES}

All Shrubs and Vines listed on pages 64,65 and 66 are delivered prepaid by parcel post or express.

\section{A SATISFIED CUSTOMIER FROM THE STATE OF WASHCRGTON}

After receiving a shipment of plants from us, MT. H. W. Fuehres, Vancouver, Wash., wrote us as follows: "Will say that they are the finest plants I have ever received. I am well pleased with them.'

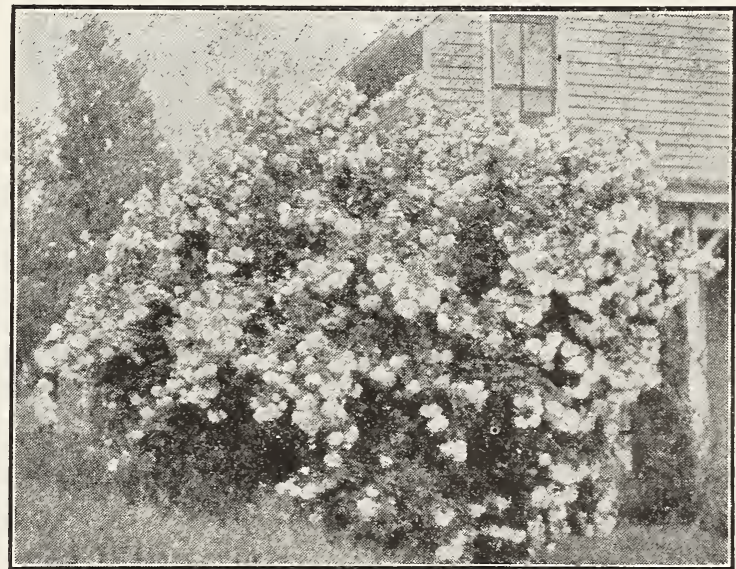

Snowball 


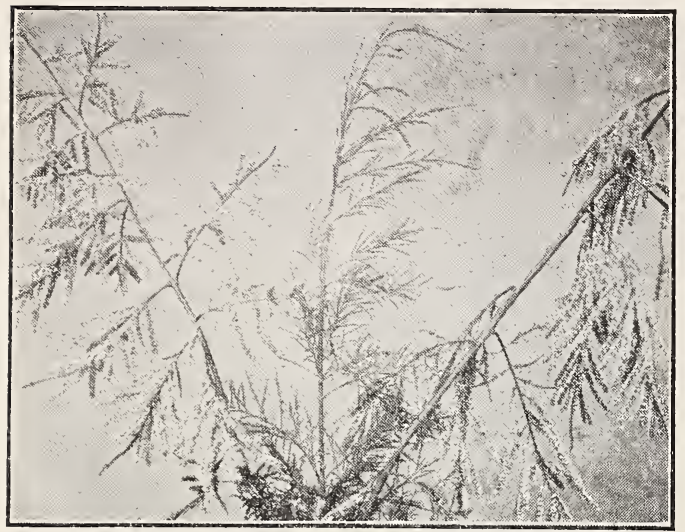

Tamarix

\section{SHRUBBERY - Continued}

SYMPHORICARPOS, Raeemosus (Snowberry) (B). Graceful shrub. Flowers pinkish-white, in loose racemes, in summer, followed by clusters of milk-white berries, which remain on the branches until way in the winter. 40c each.

Vulgaris (Coral Berry) (B). Similar to Snowberry, except that its fruits are red. A grand shrub. Large plants, 60c each.

TAMARIX, Africana (D). Fine feathery foliage like that of Juniper. Delicate pink flowers, borne profusely on graceful drooping branches, which have red bark. Hardy and wili thrive in almost any situation; will do well in the poorest, dry sandy soil. A beautiful shrub. Large 2 year old plants, 65c eaeh.

WEIGELA, Rosea (B). Rose colored flowers. Blooms in June. An elegant shrub. 40c each.

\section{We Pay the Postage or Express Charges}

on all Shrubs and Vines listed on pages 64,65 and 66

\section{Special Offer on Spirea Van Houttei}

We have a large supply of the $25 \mathrm{c}$ size plants of Spirea Van Houttei, so are making a special offer on them in lots of ten or more. 10 for $\$ 1.00 ; 25$ for $\$ 2.25$; or in lots of 50 or more at $8 \mathrm{c}$ each, delivered prepaid anywhere in the United States. There are very few large lawns that could not be improved in appearance by a foundation planting, a large clump or two, or a hedge of Spirea Van Houttei.

\section{Special on Forsythia Intermedia}

We have a surplus of these shrubs in three year old stock, the most of them too large to send by parcel post without trimming back. To close them out, we are going to offer them to our customers at: 7 for $\$ 1.00 ; 20$ for $\$ 2.50 ; 50$ for $\$ 5.00$, by express, not prepaid.

\section{Hardy Climbing Vines}

(F) denotes vines that do extra well in shady places. (G) denotes vines that do extra well in hot, sunny situations. (H) denotes vines that are.especially suited for growing on north side of house. (I) denotes vines that are especially suited for growing on east side of house.

AMPELOPSIS, Veitchii (Boston Ivy) (H). A grand hardy climbing vine for covering houses, churches, schools, etc. Clings firmly to the smoothest surface of rock or wood. The glossy leaves assume, in the autumn, the most beautiful tints of scarlet and crimson. The best vine in existence for growth on brick walls. Fine 2 year old vines. 50c each.

Quinquefolia (Virginia Creeper). During the fall months it is the most beautiful of all hardy vines, the deeply cut leaves turning to a most vivid crimson color. Unsurpassed for covering trees, rocky slopes, fences, etc. 30c each.

CELASTRUS SCANDENS (Climbing Bitter Sweet) (F). A most desirable climber; handsome, large leaves; yellow flowers in May and June and clusters of ornamental orange-capsuled fruit in autumn. 40c each.

CINNAMION VINE. Beautiful fragrant, easy growing tuberous-rooted climber. Perfectly hardy, thrive on all solls, in sun or shade, wet or dry. No insects or blight ever trouble. Will quickly surround your windows, arbors and porches with a mass of vines, and profusion of flowers which perfume the air for a long distance. Grow 30 to 40 feet in a single season. 15 c each; 3 for $35 \mathrm{c} ; 12$ for $\$ 1.00$.

CLEMIATS, Paniculata (Japanese Clematis) (G). The finest small flowered Clematis. Rapid grower; flowers pure white, fragrant, and produced very freely in large clusters. A very desirable vine. 40c each.

Henryii (H). Finest white Clematis. Flowers 4 to 6 inches in

diameter. Blooms freely during summer and fall. Very hardy. $90 \mathrm{c}$ each.

Jackmanii (H). Same as Henryii, except that the flowers are a rich violet-purple. 90c each.

Madame Andre $(H)$. Same as Henryii, except that the flowers are bright crimson in color. 90c each.

DUTCHMAN'S PIPE (G). Brownish flowers, resembling a miniature pipe. An ideal vine for situations requiring dense shade; leaves deep green, very large, broad and closely laid; vine grows rapidly. 40c each.

HONEYSUCKIL, Japonica Halleana (Hall's Japanese) ( $F$ or G). Flowers white, changing to yellow. 35c each.

MATRIMONY VINE (I). Handsome trailing vine, covered with scarlet fruit in autumn. 35c each; large size, 50c.

TRUMPET VINE (G). Very hardy and rapid grower. Used for covering unsightly places, stumps, or wherever a showy flowering vine is desired. Produces clusters of trumpet-shaped, orange-scarlet flowers about 3 inches long. If tops are kept cut back it makes a beautiful bush for the lawn, 25c each; large size, 40c.

WISTARIA, Chinese Purple (G or I). Strong, rapid grower, desirable for trellises, porches, etc. The light purple flowers are very showy, and are produced in long racemes. A large vine in bloom is a beautiful sight. Perfectly hardy. 50c each; large size, \%5c.

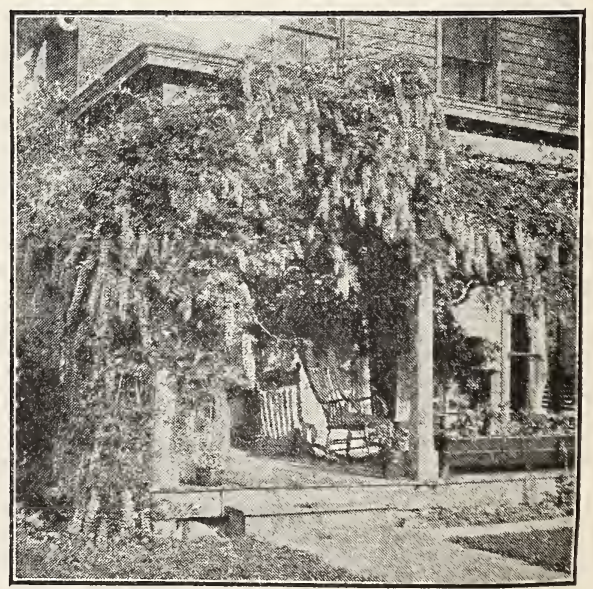

Wistaria 


\section{Ornamental and Shade Trees}

BIRCH cut-Leaved Weeping. Its tall, slender, yet vigorous growth, graceful drooping habit, silvery white bark and delicately cut in a.single tree. Very popular for single lawn specimens or groups of three or four trees; the white bark of trunk and twigs gleaming conspicuously among the darker greens and browns. One for \$2.35, or two or more at $\$ 2.00$ each, by parcel post, postpaid; by express, not prepaid, $\$ 2.00$ each or two or more at $\$ 1.75$ each. BECHTEL'S CRAB Double Flowering. The finest of all small appearance of being covered with delicate pink roses, scenting the atmosphere for a long - distance with a perfume surpassing the fragrance of the Tea Roses. The cut blossoms have often been taken for roses. The ideal lawn tree for the small yard. \$1.25 each, by parcel post, postpaid; 90c each, by express, not prepaid.

CATALPA BUNGEII (Umbrella Catalpa). Grafted on straight. heart-shaped, deep green, lying like shingles on a roof; always making a symmetrical head. Usually set in pairs on opposite sides of walk, entrance, etc. One for $\$ 2.00$, or two or more at $\$ \mathbf{1 . 7 5}$ each, by express, not prepaid. Can not be sent by parcel post.

PRUNUJS PISSARDI (Purple Leared Flowering Plum). A distinct and handsome little tree, rarely over 20 feet that deepens in color as the season advances. Covered with a mass of small white flowers in spring. Very handsome from early spring to late fall. A beautiful ornament to the lawn; fine for color massing or as a single specimen. \$1.25 each, by parcel post, postpaid; 90c each, by express, not prepaid.

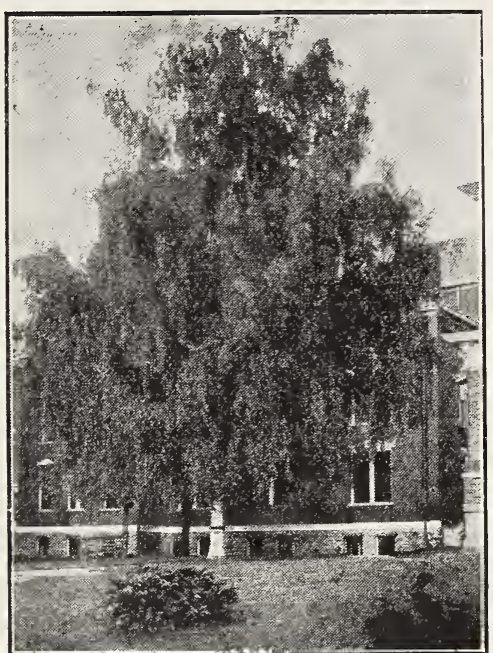

Cut-Leaved Weeping Birch

WEEPING MULBERRY Forms a perfect shaped head, with long, slender, willowy branches, drooping 作 be sent by parcel post.

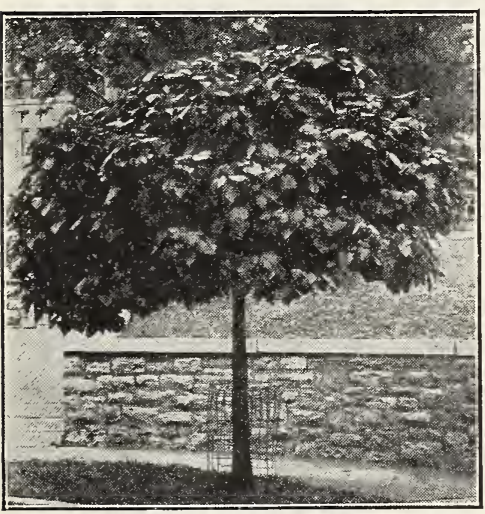

Catalpa Bungeii

\section{Bargains in Small Size Trees}

Small trees often transplant better than large ones, and mature into shade trees nearly as soon. The trees we offer of the following varieties are real small sizes, the most of them running from 12 to 24 inches. It does not set them back to transplant them, like it does a larger tree. Large and small trees set at the same time will be almost identical in size at the end of a few years-never more than a year or two difference, and often the little trees will outgrow the large ones. Our young trees will make fine specimens, and what does an extra year or so mean in the growing of a nice tree for your lawn. This is your opportunity to get all the shade trees you want at very little cost. We deliver all these trees prepaid. Pick out what you want from the following list of varieties:

ALIANTHUS (Tree of Heaven)
ASH, American White
BALM OF GILEAD
BEECH, American
CATALPA SPECIOSA
ELM, American White
*MAPLE, Silver or Soft
*MAPLE, Hard
*MAPLE, Ash-Leaved (Box Elder)
MOUNTAIN ASH

MULBERRY, Russian *PERSIMION, American POPLAR, Carolina POPLAR, Lombardy

RED BUD (Judas Tree)

*SYCAMORE, American

TULIP TREE (Lirodendron)

*WALNUT, Black

WALNUT, White (Butternut)

WHLOW, Weeping PRICES Your choice of the above 20 kinds of trees, 30 c each; 3 for 60 c; 7 for $\$ 1.00$, delivered to you by parcel post,
postpaid. Varieties marked with an asterisk (*) can be supplied in larger size at double the above prices.

\section{Satisfied Customers from California and Texas}

"The trees arrived in good condition yesterday. They were packed splendidly and will recommend you to my friends," Mrs. Charles Day, Windsor, Calif.

"I order from you every year and find your seed does better here than any I can buy." Mrs. L. C. Higgins, Bryan, Texas.

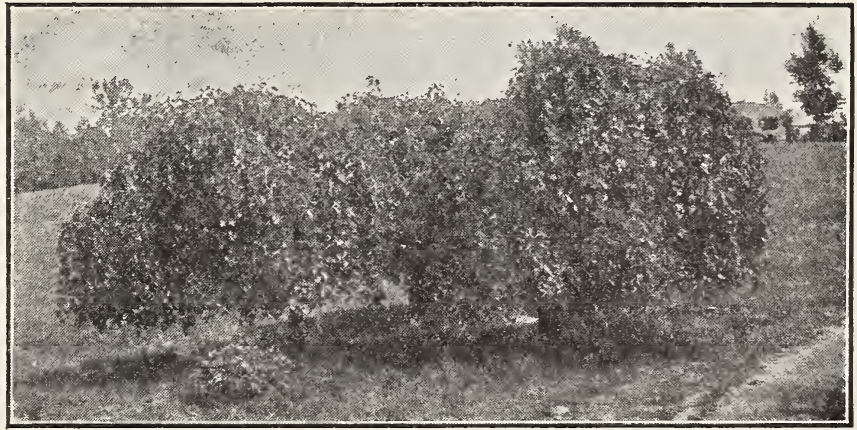

Weeping Mulberry 


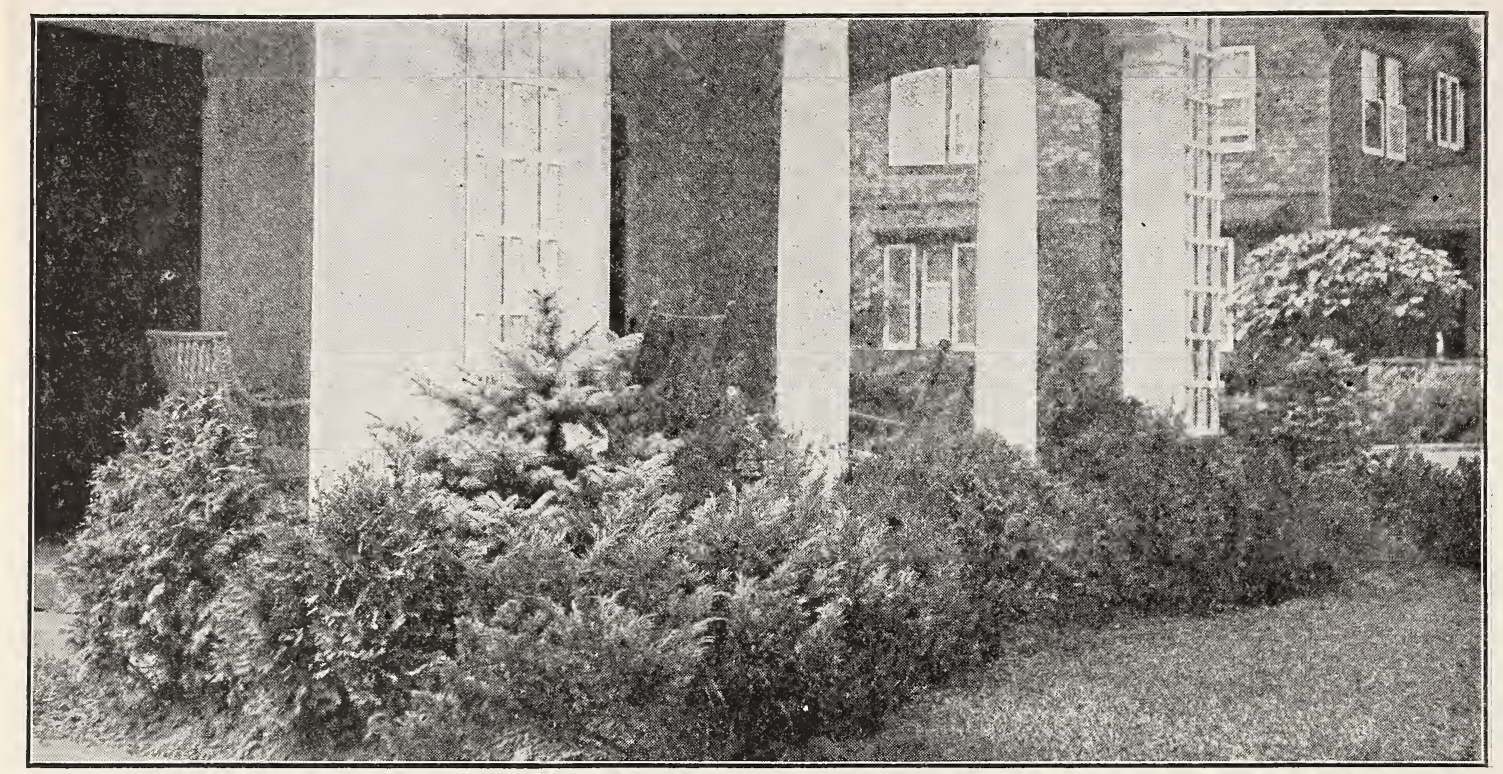

Foundation Planting of Evergreens

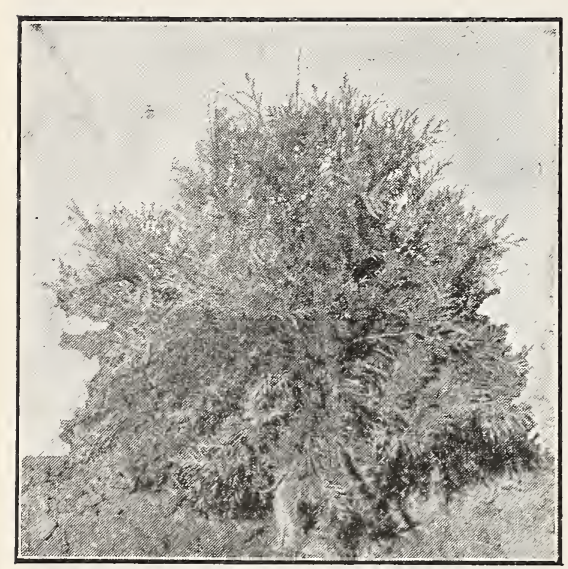

Golden Arbor Vitae

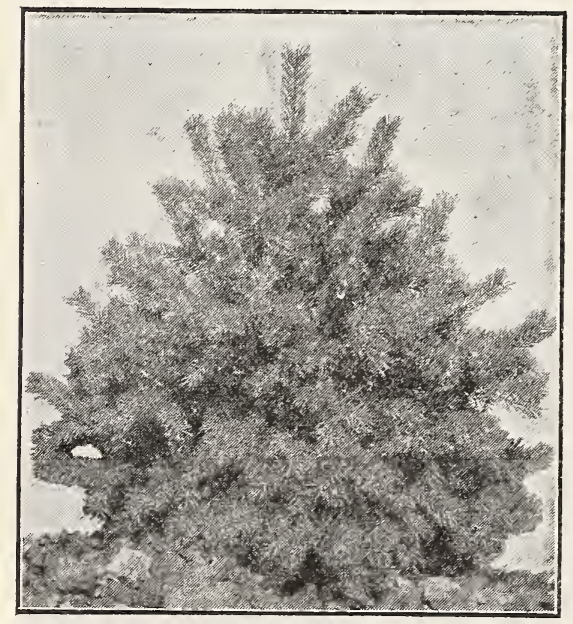

Scotch Pine

\section{Evergreen Trees}

Owing to their habit of holding their foliage the year around, Evergreens are becoming more and more popular. Our Evergreens are all carefully grown, and have been given the best of care under the supervision of Evergreen specialists who understand growing Evergreens in such a manner as to insure their being transplanted successfully to new homes with ordinary care.

Figures following specific names indicate approximately the height of the plant when approaching maturity. Grouping close together will keep them from growing larger. The tall growing varieties can also be kept small by trimming. In other words, you can have trees of any size you want-4 feet or 60 feet-by trimming and by the proper grouping or massing.

The best time to plant Evergreens is April and May. Evergreens can not be safely carried through the winter in storage, so can not be shipped until the frost is out of the ground in the spring. Some Southern planters have the mistaken idea that they should set out Evergreens earlier than the Northern planting season. This is true of most nursery stock, but not of Evergreens. Regardless of your climate, Evergreens should, for best results, be set out at the time the plants are in the proper transplanting condition. Our hardy, Northern grown Evergreens are the best for planting in either the South or North, and they are usually in the very best condition to transplant from about April 1st to May 20th. Send your order early. We will ship at the proper time for planting our Northern grown Evergreens in your locality.

ARBor VITAE, American. 30 feet. A well known and very valuable Evergreen for screens, windbreaks and hedges and as single specimens and landscape work. It has flat beautifully carved foliage of deep green. Usually seen as a narrow, pyramidal tree 5 to 10 feet high and half as wide, but will grow to be a large tree. Because of the fact that it bears shearing better than any other variety, and because of its compact growth, it heads the list for Evergreen hedge planting. For 3 to 4 foot hedge, plant 15 inohes apart; 4 to 5 foot, $2 \theta$ inches apart; 5 to 7 foot, 24 inches apart. 35e each; 5 for $\$ 1.25$; 10 for \$2.25, postpaid. 18c each in lots of 50 or more, by express, not prepaid.

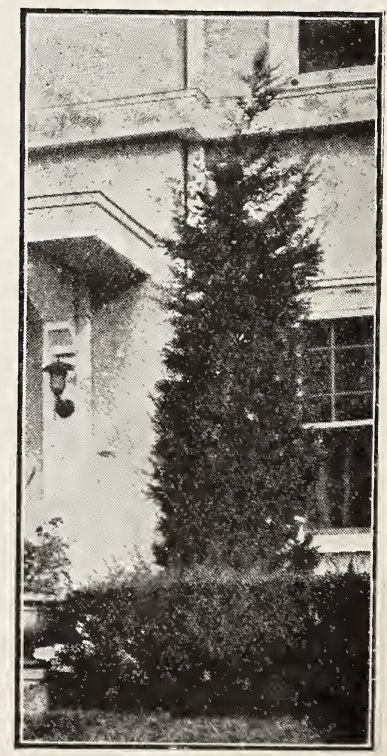

Oriental Arbor Vitae 
ARBOR VITAE, Oriental or Chinese. 15 feet. A pyramidal growing evergreen that is most valuable in group planting. Foliage light, lustrous green; color changing in winter to rich bronze with reddish tinge. 60e each, 3 for $\$ 1.50 ; 10$ for $\$ 4.00$, by parcel post, postpaid.

ARBOR VITAE, Golden. 15 feet. Foliage of a very showy, golden yellow. Used extensively in landscape plantings, for there is nothing quite so attractive in a group of Evergreens as a flash of rich golden yellow. $75 \mathrm{c}$ each; 3 for $\$ 2.00 ; 10$ for $\$ 6.00$, by parcel post, postpaid.

JUNIPER, Irish. 8 feet. Foliage bluish-green. Very dense and upright habit. Fine for columnar effect in landscape work. Makes a tall and very narrow hedge. For a 3 to 4 foot hedge, plant 12 inches apart; 4 to 5 feet, 15 inches apart. $60 \mathrm{e}$ each; 3 for $\$ 1.50 ; 10$ for $\$ 4.00$; by parcel post, postpaid. $35 \mathrm{c}$ each in lots of 50 or more by express, not prepaid.

JUNIPER, Virginiana. 25 feet. Form tapering, symmetrical. Foliage varies from light green to dark green, grayish green and bluish green; color good at all times, but its bronzy appearance in fall and early winter is very attractive. Thrives well on poor soil. 60c each; 3 for $\$ 1.50 ; 10$ for $\$ 4.00$, by parcel post, postpaid.

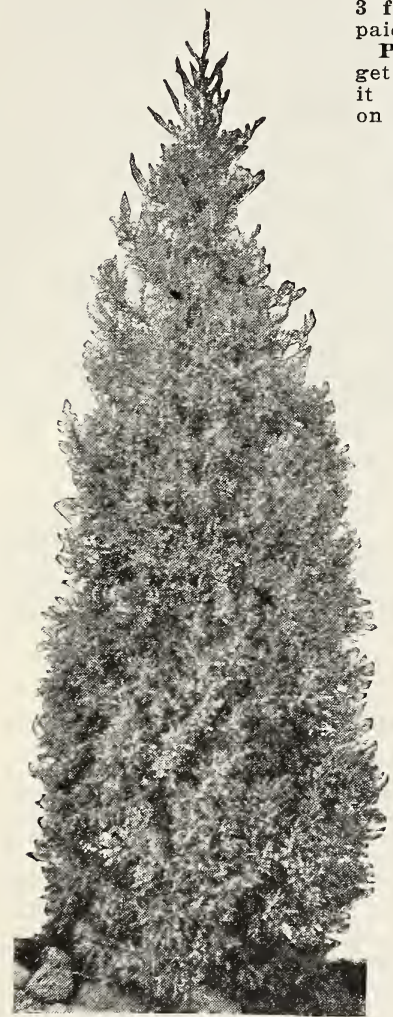

Juniper Virginiana

PINE, Scotch. 50 feet. Here is where you get the most Pine for the least money, because it grows rapidly when young; thrives well $n$ the poorest soil and is one of the best all-round Evergreens to withstand extreme exposure and unfavorable conditions. Makes a big, broad-shouldered tree highly resistant to wind or drought or cold. It is an attractive tree, with slender, dark green needles, is vigorous in growth and makes quick and attractive windbreak. It is a handsome tree in its prime, and is used considerably by landscape men in ornamental plantings. 60 each; 3 for $\$ 1.50$ 10 for $\$ 4.00$, by parcel post, postpaid.

SPRUCE, Colorado Blue. 30 feet. Nature has produced a myriad of beautiful trees, but last of all she has made the Colorado Blue Spruce as a crowning glory of them all. Into this wonderful ornamental tree has been combined a silvery blue luster, perfection in form and symmetry, and hardy characteristics that make it adaptable to nearly all

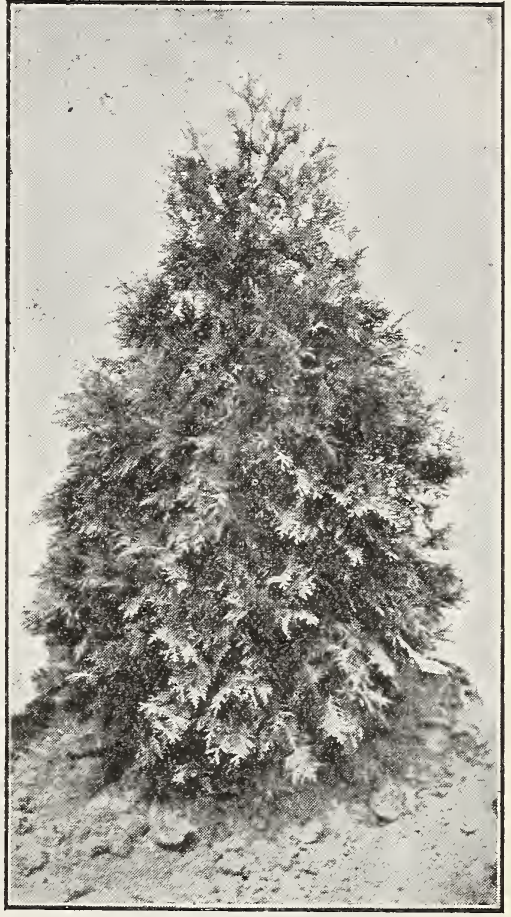

American Arbor Vitae

climates. It can be used very effectively when planted individually, in groups by itself, or in groups with other Evergreens, where it should be planted in the foreground to display its coloring and form. In the spring of the year the Blue Spruces are off-color, and if transplanted will not regain their bluish color until they start to make a good growth. It is the new growth that brings out and renews the silvery luster, and the bluish tint becomes more in evidence as the tree grows older. \$1.00 each; 3 for $\$ 2.50 ; 10$ for $\$ \% .00$, by parcel post, postpaid.

SPRUCE, Norway. 50 feet. The Norway Spruce makes a large fine looking tree, is the most rapid grower of the Spruces, thrives in a great variety of soils, is hardy everywhere. It stands close planting and severe pruning. It is the most popular tree for windbreaks and with its compact, heavy growth clear to the ground provides a complete shelter to the buildings and grounds back of it. Hedges 25 years old can be trimmed down to a height of four feet, whereas the natural growth would be 50 to 60 feet. Foliage is dark green; needles short and stiff. In addition to its value as a windbreak and hedge plant it is, owing to its beautiful form and foliage, probably more generally planted for landscape purposes than any of the other Spruces. For a 2 to 3 foot hedge, plant 15 inches apart; 3 to 4 foot, 20 inches apart; 5 to 6 foot, 2 feet apart; 6 to 8 foot, $2 \frac{1 / 2}{2}$ feet apart; 8 to 10 foot, feet apart. 35c each, 5 for $\$ 1.25,10$ for $\$ 2.25$; by pareel post, postpaid. 18c each in lots of 50 or more by express, not prepaid.

\section{Correct Distance to Plant Evergreens for Windbreaks}

The distance apart that Evergreens should be planted depends very much on the number of rows used. Five feet apart in a single row, 8 feet apart each way in a double row, or 12 feet each way in three rows is about right. Or, you can set out a four or five row windbreak, planting 12 or $14 \ldots$ et apart in the row and the rows 20 feet apart. In this way the space between the rows can be used for potatoes, corn or vegetable garden.

\section{SPECIAL EVERGREEN OFFER}

One each of the eight kinds of Evergreens offered on this page and page 63, delivered to you, prepaid, for only $\$ 3.75 ; 3$ of each for $\$ 10.00$. A fine collection for a foundation plànting.

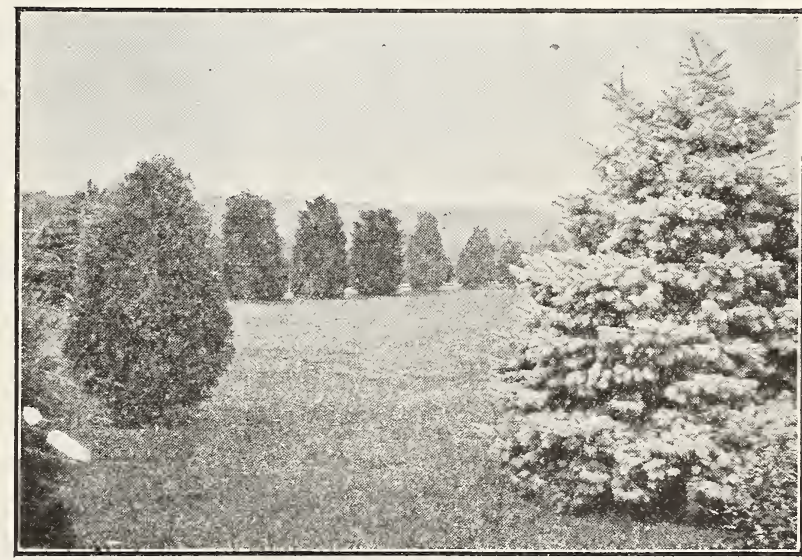




\section{Now Is the Time to Make Big Money Growing Medical Plants}

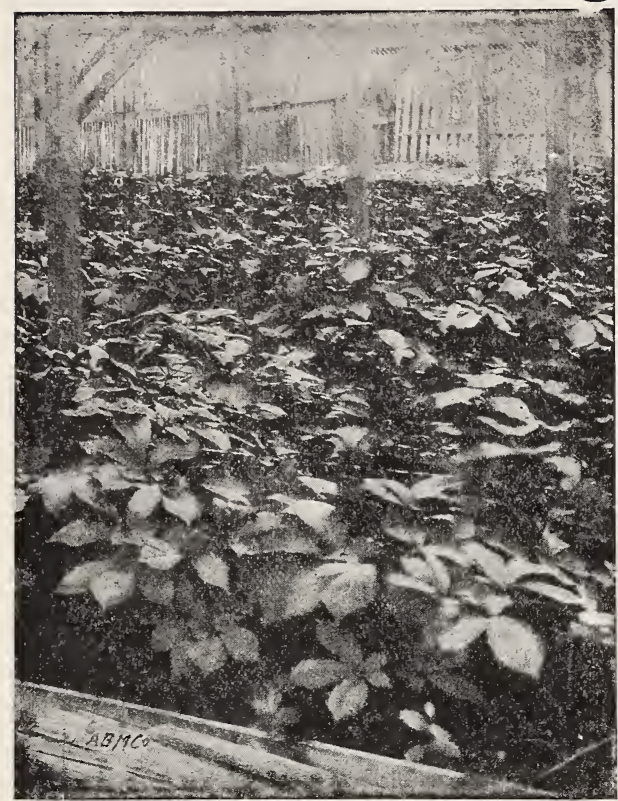

A Bed of Ginseng

for planting. Sold in sealed packets only. (ond ad resses of medical root buyers who will rod. Pkt., 25c; 5 pkts., $\$ 1.00 ; 12$ pkts., $\$ 2.00 ; 3$

Drugs have greatly increased in prices during the past few years, so now is the time to commence growing root crops for medical purposes. Golden Seal and Ginseng are the two biggest money makers of them all. These roots now sell at enormous prices, and we believe we would be safe in saying that they will never be any cheaper than now. In fact, there is no reason why the prices on these roots will not steadily increase year after year. These plants formerly grew wild in most of the Northern States, and in many parts of the South, and it was from these wild plants that the supply of roots was formerly secured. The crop of wild roots is now nearly exhausted, and it has become necessary to cultivate these plants. The demand is increasing each year, and the supply decreasing, so you will be making no mistake if you devote a part of your time to the growing of these two plants.

\section{Golden Seal}

If you want to get started in the growing of medical plants, dor.'t fail to plant some Golden Seal this year. It is easily grown, and is a sure money maker. When ready to dig, the roots should average at least one ounce each, green. This would make 18 pounds of dry roots to each square rod. At the present price of $\$ 4.50$ a pound this would bring you $\$ 81.00$ for the square rod. At this rate an acre would be worth $\$ 12,960.00$. Besides this, enough small plants will be found to set out twice as large a patch and the fibrous roots that are left in the ground will form buds and reset the patch.

The figures we give are not overdrawn in the least. One of the leading buyers of medicinal roots says he bought a crop of cultivated Golden Seal that averaged nearly 8 ounces per root, dried. They were worth about $\$ 2.25$ each. Think of it! An acre of such Golden Seal would bring $\$ 316,800.00$. Any good, well drained soil is suitable for the growing of Golden seal. Seed should be planted in the fall, but as our supply will be limited, we, in all probabillties, will be unable to supply you with seed unless you send your order at the time you order your other seeds. Order now (send cash with order) and seeds will be mailed to you at the proper time ch order for seed we will send complete cultural directions and the pkts., $\$ 5.00 ; 80$ pkts., $\$ 10.00 ; 250$ pkts., $\$ 25.00$, postpaid.

\section{Ginseng}

Ginseng is another money maker. Read the following news item, clipped from a Wisconsin daily paper:

"Wausau wis. May 21-(Special)-Perhaps by far the most valuable load of products of the soil that ever crossed the streets of Wausau, was seen a few days ago, drawn by one horse. The load consisted of eighteen inconspicuous barrels and no one would have surmised its value had it not been that J. H. Koehler was seen watching it with eagle eyes. Upon inquiry it was found that the barrels contained $1,3431 / 2$ pounds of ginseng, which had been sold for $\$ 8,061$, and was now being started on its long journey to China. The crop was grown on one-half acre of ground near Wausau."

The average market price of dry ginseng roots is generally about $\$ 7.00$ or $\$ 8.00$ per pound, but at the time of going to press with this catalog, buyers are paying from $\$ 12.00$ to $\$ 13.00$ per pound for roots of the best quality, and there seems little likelihood of any radical slump in price.

Ginseng should be planted only in the fall, but to be certain of getting the seed, you should order same as soon as possible, for we will probably have our supply all sold long before planting time. The best way is to order your Ginseng seed at the same time you order your other seeds; then we can be sure to supply you. With each order for seed we will send complete cultural directions and names and addresses of buyers who will buy the roots from you. 36 packets of seed will plant one square rod. Pkt., 25c; 5 pkts., $\$ 1.00 ; 12$ pkts., $\$ 2.00 ; 36$ pkts., $\$ 5.00 ; 80$ pkts., $\$ 10.00 ; 250$ pkts., $\$ 25.00$, postpaid.

\section{Golden Seal and Ginseng Plants}

Many of our customers wish to set out Ginseng and Golden Seal plants, and get a patch started in that way, instead of planting seed, and to such persons we can supply plants in limited quantities. Others want to know how to identify these plants when they find them growing wild. It is rather difficult for us to so describe them that one can be positive in their identity after reading the descriptions only, but we can supply any of our customers with one or more of the plants, which will be a positive guide to anyone wishing to dig wild plants.

We have but a limited number of the plants to offer, so would _ommend that you place your order as early as possible. Plants will then be sent at the proper time for transplanting. Golden Seal plants can be supplied either spring or fall; Ginseng plants, fall only. Plan on setting about 800 plants to each square rod.

Prices of either Golden Seal or Ginseng Plants: One plant, 25e; 6 for $75 \mathrm{e} ; 12$ for $\$ 1.25 ; 25$ for $\$ 2.00 ; 50$ for $\$ 3.50 ; 100$ for $\$ 6.00 ; 250$ for $\$ 13.50$; 500 for $\$ 25.00 ; 1.000$ for $\$ 45.00$; delivered to any part of the United States, prepaid.
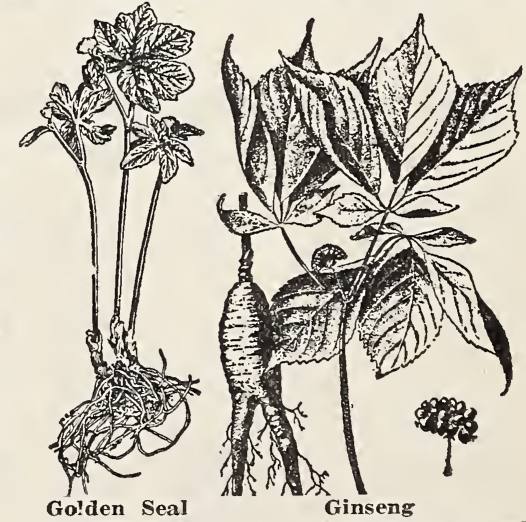

A Pleased Customer from Mexico "In the month of April last, I ordered from you some 21 作 were three weeks on the road, and they are all doing fine. 


\section{Cooper, the Biggest Strawberry Grown}

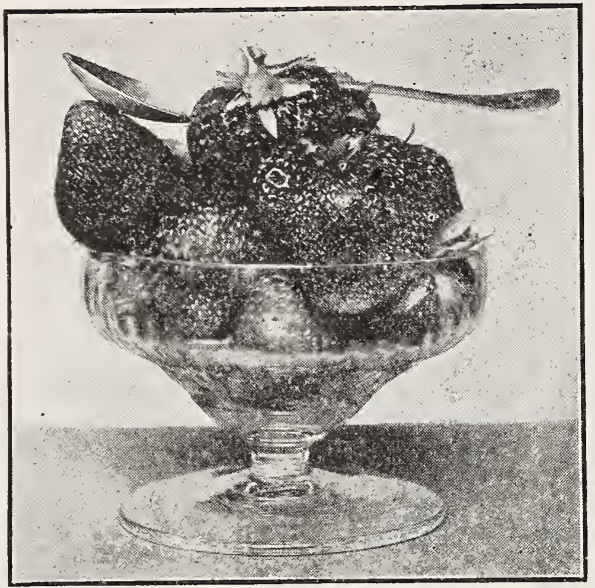

Cooper

Strawberry growers have for many years been clamoring for a strawberry that would combine large size and productiveness. We are now able to offer such a berry. This new variety has created a sensation in the horticultural world. Growers all over the country are discarding all other varieties. Ne variety is more productive than the Cooper, and no variety surpasses it in shape, color, appearance, quality, size and delicious flavor. It is the most thrifty strawberry grown, the root system being the greatest ever developed by any variety of strawberry. The plants often grow to more than a foot in height, thus affording shade to the enormous loads of fruit and also a protection from frosts. Cooper is without a single exception the best strawberry grown, medium-early, and a big money maker.

PRICES: 25 for 75c; 50 for \$1.25; 100 for \$2.25, by parcel post, postpaid. If you want plants sent by express, you to pay the express charges, we can quote you $\$ 1.75$ per $100 ; \$ 3.50$ per 250 ; or $\$ 11.00$ per 1,000 in lots of 500 or more.

\section{Premier, the Earliest of All}

It is impossible to say too much in praise of this most wonderful of all early strawberries. While it is the earliest strawberry ever produced, it is so frost resistant in both bud and blossom that its fruit crop has never been destroyed. Think what this means to the market grower. Premier eliminates crop uncertainties, and by rípening five days to a week ahead of any other kind, it never fails to command the highest prices. Berries are large, of a bright red color, and more uniform in size than any other kind. It is a general all around strawberry, equally good for market, table use or canning.

PRICES: 25 for 60 ; 50 for $\$ 1.00 ; 100$ for $\$ 1.75$, by parcel post, postpaid. If you want plants sent by exprezs, jou to pay the express charges, we can quote you $\$ \mathbf{1 . 2 5}$ per $100 ; \$ 2.50$ per $250 ;$ or $\$ 8.00$ per 1,000 in lots of 500 or more.

\section{Eaton, the Best for Canning}

Eaton is a medium-late strawberry and is one of the heaviest yielding varieties ever produced. All berries are large in in size and rich, dark red clear through to the he long distant shipper. As a canner, Eaton leads them all. No matter how long they remain in the can they will not discolor or soften.

PRTCES: 25 for 60c; 50 for $\$ 1.00 ; 100$ for $\$ 1.75$, by parcel post, postpaid. If you want plants sent by express, you to

\section{The Big Money Maker Berry} $\$ 1000.00$ a Year per Acre with Lucretia Dewberries

Dewberries are bringing big money and we are advising our customers to get started with them as soon as possible. Lewberries are larger than any blackberry, sweeter and milder in flavor, and of excellent quality for home use or market. They ripen a week or ten days ahead of common blackberries, the bulk of the crop being harvested before other blackberries start to ripen, so sell at very high prices.

The Dewberry belongs to the blackberry family, and the Lucretia is the best of them all. The large berries are incomparably better than any blackberry grown; of unequaled excellence; sweet and luscious throughout, and of bright glossy black color. They are very productive, and the most profitable of all fruit fruit crops trailing habit renders it less liable to winterkill. Propagates from the tips, like black raspberries; does not spread or sucker.

There are two methods of growing the Dewberry. One is to set the plants 4 feet apart in the row, with rows 6 to 7 feet apart. Allow them to grow along the row in their natural way, removing all the new growth until after blooming time, and then allow only enough new vines to grow to provide for the next crop, and at the same time shade the ripening fruit. In this way they will ripen earlier than they would tied up to wires or stakes, the whole crop being grown in Nature's own way, down among the dewy leaves unexposed to strong rays of summer sun. Controlling the new growth each season does away with the necessity of stakes or posts and wire.

The other method of growing is to use short posts and wire. Grown in this way, the fruit is much easier to pick, but is not quite as early. The posts need be only 30 to 36 inches high. Use one wire and in the spring tie all canes onto same, holding them off the ground. Let the new canes lie on the ground throughout the growing season, covering them slightly for winter protection in climates where the winters are severè. Cut away old wood in spring and tie new canes on wire, or old wood can be removed soon after harvesting the crop.

We absolutely guarantee our plants to be the genuine large fruited Lucretia. About 1,700 plants are required to sett an acre.

PRICES: 6 for $65 \mathrm{c} ; 12$ for $\$ 1.00 ; 25$ for $\$ 1.75 ; 50$ for $\$ 3.00 ; 100$ for $\$ 5.50$, by parcel post, postpaid. By express, not prepấd, \$4.00 per 100; $\$ 8.00$ per 250 ; or $\$ 26.00$ per 1,000 in lots of 500 or more.

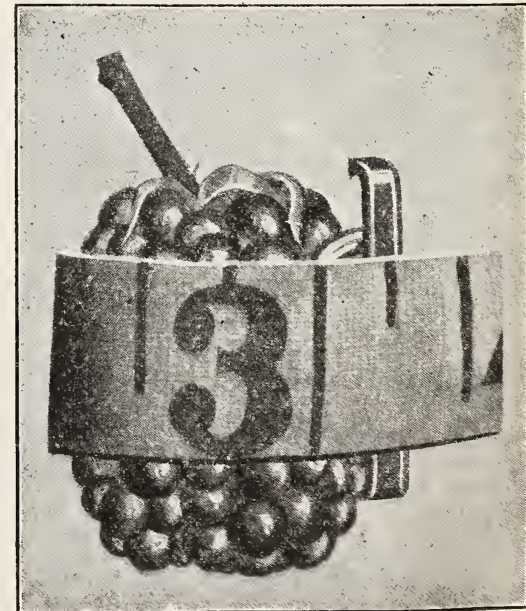

Lucretia Dewberry 


\section{Victory Raspberry}

\section{The Biggest Money Maker of all Red Raspberries}

Of all Red Raspberries grown, Victory takes a long lead in productiveness and size of fruit. To give you an idea of the tremendous size of its crops, and with same care and under exactly the same conditions, it has produced nearly twice as much fruit as Cuthbert. Victory originated in Northern Michigan and has withstood 30 degrees below zero without injury to a tip of a cane. It is a sport seedling of Cuthbert, and has some of the characteristics of that grand old variety. We have discontinued the crowing of Cuthbert owing to Victory being very much superior in every way. It is by far the best quality of any Red Raspberry, and mammoth in size, many berries measuring $1 \frac{1}{2}$ inches in diameter. Victory is, to a remarkable degree, immune to all plant diseases. Unequalled as a main crop berry for both the home garden and market. 6 for 65c; 12 for $\$ 1.00$; 25 for $\$ 1.75 ; 50$ for $\$ 3.00 ; 100$ for $\$ 5.50$, delivered prepaid to any part of the Cnited States. By express, not prepaid, \$4.50 per 100; \$9.00 per 250; or $\$ 30.00$ per 1,000 in lots of 500 or more.

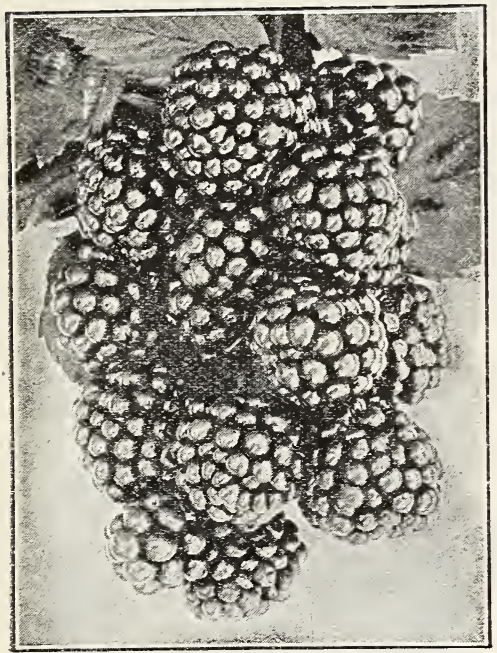

Elärado Blackberry

EARLY KING (red). The earliest and most beautiful early red raspberry. Growers all over the country are discarding other varieties, owing to the big profits that can be made growing the King. Extreme hardiness, earliness, productiveness, excellent quality, large size, firmness, and bright color which holds until placed on the most distant market, together with the fact that King plants are most vigorous growers and entirely free from disease, make it the most profitable early red raspberry to

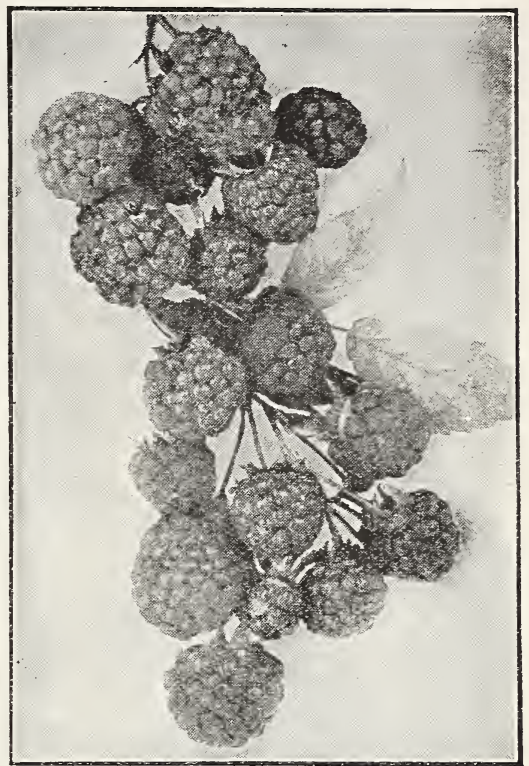

St. Regis Everbearing

grow. 6 for 50c; 12 for $80 \mathrm{c} ; 25$ for $\$ 1.35 ; 50$ for $\$ 2.25 ; 100$ for $\$ 1.00$, by parcel post, postpaid. By express not prepaid, $\$ 3.00$ per $100 ; \$ 6.00$ per $250 ;$ or $\$ 20.00$ per 1,000 in lots of 500 or more.

ST. REGIS EVERBEATRING (red). Fruit commences to ripen with the early varieties of red raspberries, and continues to produce fruit during tho summer and fall, and until the berries freeze in the fall or early winter. As to quality of fruit, St. Regis has no superior. Berries bright crimson, large size, rich, sugary, and of the best flavor. St. Regis is exceedingly hardy, the canes enduring the severest cold uninjured. Wonderfully prolific. The only red raspberry that yields a crop of fruit the first season. Plants set in the spring will commence bearing the following June. Cutting off the canes near the ground, late in the fall, prevents the summer crop and has a tendency to make the fall crop more abundant. 6 for 65 c; 12 for $\$ 1.00 ; 25$ for $\$ 1.75 ; 50$ for $\$ 3.00 ; 100$ for $\$ 5.50$, postpaid. By express, not prepaid, $\$ 4.50$ per $100 ; \$ 9.00$ per 250 ; or $\$ 30.00$ per 1,000 , in quantities of 500 or more.

CUMBERIAND (black). The largest and most productive black raspberry. Ripens medium-early and continues throughout the raspberry season. Very hardy, and the most profitable market sort. Prices same as St. Regis.

PLCII FARMER (black). The earliest black cap. Very valuable because of its extreme earliness. Fruit of excellent quality. Prices same as St. Regis.

GREGG (black). The best late black raspberry. Large and of excellent quality. Prices same as St. Regis.

COLCMBIAN (purple). A cross between a black and red raspberry, the result of which is a purple berry. Do not sucker or spread from the roots like red varieties. This makes it a most desirable sort for the home garden. Berries large, rich and juicy, and better than red or black raspberries for canning. 6 for 75c; 12 for $\$ 1.25 ; 25$ for $\$ 2.00$; 50 for $\$ 3.75 ; 100$ for $\$ 7.00$, postpaid. By express, not prepaid, $\$ 6.00$ per $100 ; \$ 13.00$ per 250 ; or $\$ \mathbf{\$ 5 . 0 0}$ per 1,000 in lots of 500 or more.

\section{Blackberries}

EIDORADO. We recommend this variety ahead of all others. The berries are large in size, very sweet, and of delicious flavor and quality. It is one of the hardiest blackberries in cultivation and has never been known to winterkill. Very productive, and never fails to ripen a crop. 6 for 65 ; 12 for $\$ 1.00 ; 25$ for $\$ 1.75$; 50 for $\$ 3.00 ; 100$ for $\$ 5.50$, postpaid. By express, not prepaid, $\$ 1.50$ per $100 ; \$ 9.00$ per 250 ; or $\$ 30.00$ per 1,000 in lots of 500 or more.

ICEBERG. This is the white blackberry. It is not merely a curiosity, for in addition to being a real novelty it is a berry of extraordinary quality. These shining creamy-white berries, when mixed with jet-black ones, make a most attractive dish. The bushes are good strong growers and very productive. For best results, this variety should be planted near other blackberries. Plants, 20c each; 3 for $50 \mathrm{c} ; 12$ for $\$ 1.50 ; 25$ for $\$ 2.75$; postpaid.

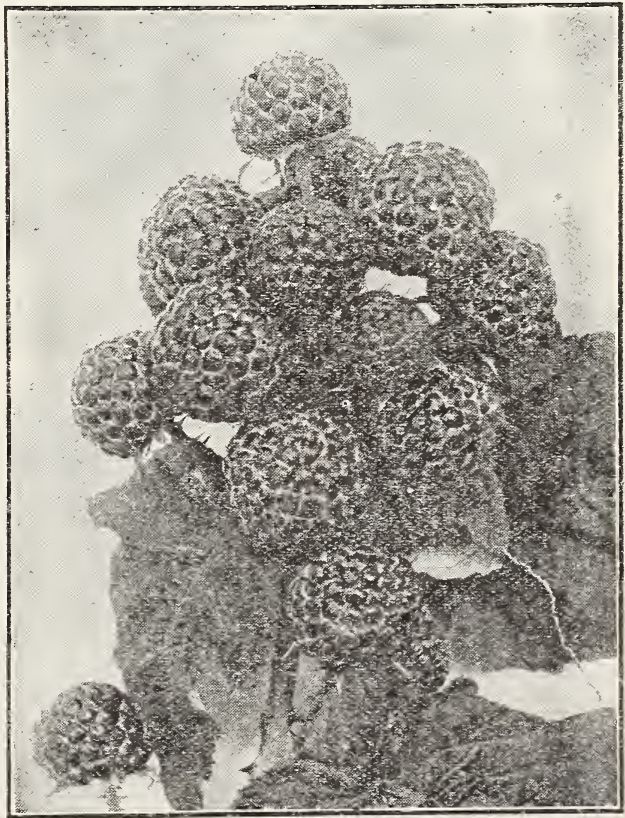

Cumberiand Black Raspberry 


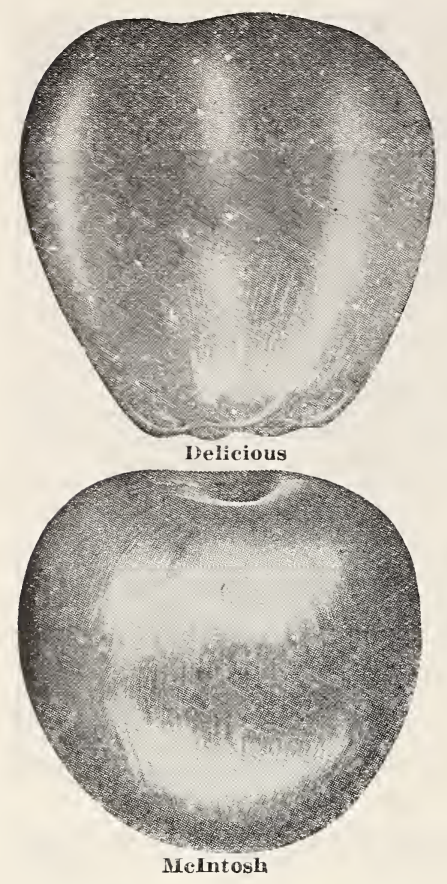

\section{ADP WS ( $\left.\begin{array}{l}\text { Hardy Northern Grown } \\ \text { Best for all Climates }\end{array}\right)$}

\section{SUMMER APPLES}

DUCHESS OF OLDENBURG. Good size, pale yellow, streaked red; juicy, sour highly esteemed for home use or market. Good crop when trees are 4 or 5 years old.

EARLY HARVEST. Fruit of medium size; bright straw color when fully ripe. Flesh of excellent quality; tender, crisp and juicy.

RED ASTRACHAN. Most attractive early red apple. Flesh white, crisp and juicy, with a pleasant acid flavor. One of the best early eating apples.

YELLOW TRANSPARENT. The earliest apple to bear; good crop when trees are four to five years of age. Skin pale yellow. Flesh white, crisp, juicy, mildly sub-acid. An excellent eating and cooking apple.

\section{FALL APPLES}

FAIL PIPPIN. Large, yellow, rich, aromatic. Fine eating apple and especially good for cooking.

MAIDEN BLUSH. Yellow with red cheek. Fruit medium to large; juicy, pleasantly sub-acid. Excellent for culinary use.

RAMBO. Medium; yellow, streaked red. Fine apple that does well nearly everywhere.

SNOW APPLE (Fameuse). Red skin, white flesh; juicy, mild, spicy and very tender.

WEATTHY. Rich dark red. Medium to large. Flesh white, sometimes stained with red. Fine grained, tender, juicy and of excellent quality. Trees mature early; bear when 4 years old and large crops every year.

\section{WINTER APPLES}

BALDWIN. Yellowish red, heavily shaded with deep red. Large, splendid keeper, good cooker, and one of the most popular varieties.

DELICIOUS. Large; striped and marked with light and dark red. Flesh fine grained, tender and flowing over with rich, highly flavored juice. Tree matures early; unusually productive.

GRMIES GOLDEN, Rich, golden yellow skin, mild sub-acid flavor, tender and juicy. A dependable and uniform bearer.

JONATHAN. Medium size, bright red apple; tender, crisp, very juicy, with a fine flavor. Comes into bearing rather young.

McINTOSH. Medium size, deep crimson, highest quality, juicy, sour. Comes into bearing rather young.

NORTHERY SPY. Large, red striped, juicy, mild sub-acid, with a rich, delicious flavor. Extra long keeper. None better for cooking or eating out of hand.

NORTHWESTERN GREENING. Hardy, yellow, rich, of good size; an extra long keeper, which makes it a stand-by to finish the winter for cooking purposes. RHODE ISLAND GREENING. Large, greenish-yellow, juicy, with a rich acid flavor. Good keeper. One of the best cooking apples.

ROX RUSSET. The most popular russet apple; russet-brown skin; a remarkable keeper, commanding good prices in the spring.

STAYMAN WINESAP. Large; deep red skin; juicy, sour, pleasing flavor. An excellent keeper.

TOLMAN SWEET. Best sweet. Yellow, medium to large. Comes into bearing moderately young.

WTNTER BANANA. Large; clear pale yellow with beautiful pinkish rea blush. Good dessert quality, but too mild to excel for culinary uses. Comes into bearing young.

CRAB APPLES

HYSLOP. Brilliant dark red overspread with thick blue bloom. The best and most reliable crab apple.

\section{SWEET CHERRIES}

BING. Few sweet cherries equal Bing in size, attractiveness and quality. Large; delicious; bears early and abundant.

BLACK TARTARIAN. A popular home garden sweet cherry; purplish-black, flesh tender, juicy and rich. Produces immense crops. Ripens earlier than Bing. GOVERNOR WOOD. Light yellow, marbled with red; very large; juicy, rich and delicious. Extra early.

LAMBERT. A very sweet variety and one of the largest. Dark purplish red, turning almost jet black when ripe. Later than Bing.

NAPOLEON. Yellow, with bright red cheek; very large, meaty and sweet. Very productive; bears young.

PRICFS STANDARD SIZE, $\$ 1.25$ each; 3 for $\$ 3.50 ; 5$ for $\$ 5.75 ; 10$ for $\$ 11.00$, by parcel post, postpaid. By express, not prepaid, 10 or more at 5 e each; 50 or more at $85 \mathrm{c}$ each; 100 or more at $80 \mathrm{c}$ each.

EXTRA STANDARD. \$1.25 each; 3 for $\$ 3.50 ; 5$ for $\$ 5.75$; 10 for $\$ 11.00$; 50 for $\$ 50.00 ; 100$ for $\$ 95.00$, by express, not prepaid.

\section{SOUR CHERRIES}

EARLY RICHMOND. A dependable variety which seldom misses a crop. Dark red. Best early sour cherry.

LARGE MONTMORENCY. Large red cherry; larger than Early Richmond and fully ten days later. The leading commercial variety.

ENGLISH MORELLO. The standard late sour cherry. Very dark red, almost black; excellent quality. A month later than Montmorency.

PRICES STANDARD SIZE. \$1.00 each; 3 for $\$ 2.75 ; 5$ for $\$ 4.50 ; 10$ for RICES \$8.50, by parcel post, postpaid. By express, not prepaid, 10 or more at $70 \mathrm{c}$ each; 50 or more at $60 \mathrm{c}$ each; 100 or more at 5̃ each.

EXTRA STANDARD. $\$ 1.00$ each; 3 for \$2.75; 5 for $\$ 4.50 ; 10$ for $\$ 8.50 ; 50$ for $\$ 3 \% .50 ; 100$ for $\$ 70.00$, by express, not prepaid.

Plant Northern Grown Trees for Best Results

\section{Prices of Apple}

\section{Trees}

STANDARD ( 3 to 4 feet). $80 \mathrm{c}$ each; 3 for $\$ 2.00$; 5 for $\$ 3.00 ; 10$ for $\$ 5.50$, by parcel post, postpaid. By express, not prepaid: 10 for $\$ 4.00$ 50 for $\$ \mathbf{1 8 . 0 0 ;} 100$ for $\$ 34.00$.

EXTRA STANDARD year 4 to 6 feet, well branched). 80c each; 3 for $\$ 2.00$; 5 for $\$ 3.00$; 10 for $\$ 5.50 ; 50$ for $\$ 26.00 ; 100$ for $\$ 50.00$, by express, not prepaid. These trees are too large to send by parcel post.

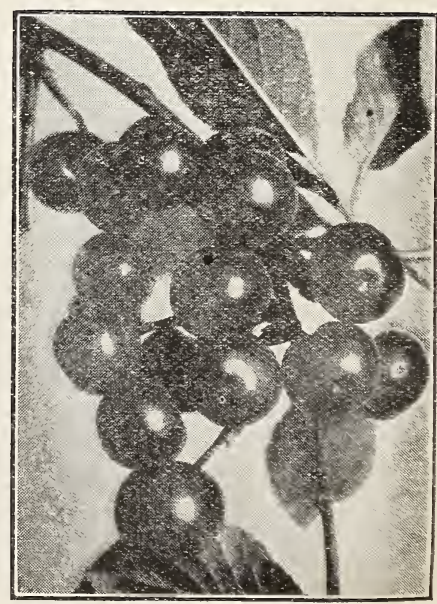

Bing Cherries 


\section{PEACHES}

We have picked out what we consider to be the best eight varieties of Peach-those that have proven their worth under the most unfavorable conditions and in all soils and climates. If you will limit your planting to these varieties you will be making no mistake. It is best to plant a few peach trees each year, in the home garden, as the younger trees as a rule bear fruit of better quality and in that way you have trees coming into bearing each year.

BELLE OF GEORGIA. Very large, white fleshed with red cheek; firm, juicy and excellent flavor. Very hardy and grows with equal success in both North and South. Productive; early; stone semi-free to free. The most beautiful white peach grown.

CARMAN. One of the Carman's greatest assets is its rugged constitution which enables it to withstand trying climates, and to accommodate itself to a great variety of soils. Flesh white, red at the pit, juicy, rich and sweet. Stone nearly free. Early.

CRAWFORD LATE. A grand, large, yellow freestone. One of the best late varieties.

FLBERTA. The most popular peach grown. Large, yellow with red cheek; flesh yellow, firm, juicy, highly flavored, rich and sweet; exceedingly prolific, sure bearer and hardy. An ideal mid-season variety. Freestone.

HAI,E. Beautiful golden yellow overlaid with bright carmine; larger than Elberta and ripens a week earlier. Good shipper and keeper, and on the market it commands the highest price. Freestone.

KALAMAZOO. A beauitful peach that will bear good crops of fruit when all other varieties fail. The surest cropper of them all, and very hardy. Large, golden yellow with crimson cheek; yellow flesh, superb quality, small pit. Mid-season. Freestone.

LEMON FREE. Lemon-shaped and colored, large size, freestone, immensely productive, excellent quality. One of the best commercial peaches and the most popular for canning. Late.

ROCHESTER. In a class by itself because it is the only good sized yellow freestone peach of fine quality ready for market from the 10 th to the middle of August in the Northern States. Large, yellow with a most attractive red blush; juicy, delicious and

$$
\begin{aligned}
& \text { keeps well. } \\
& \text { very hardy. }
\end{aligned}
$$

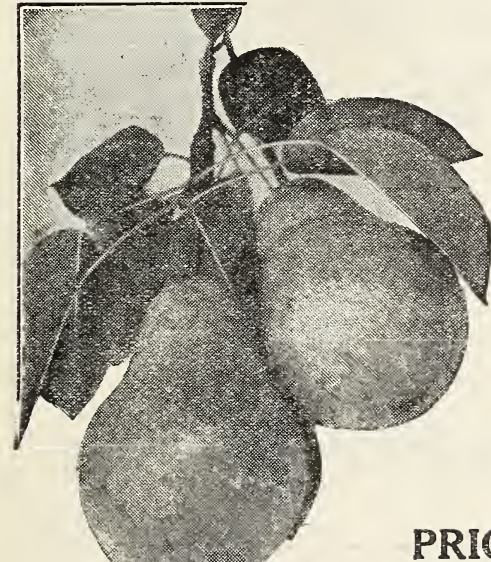

\section{Prices of Peach Trees}

STANDARD SIZE. 650 each; 3 for $\$ 1.75 ; 5$ for $\$ 2.50 ; 10$ for $\$ 4.50$, by parcel post, postpaid. By express, not prepaid, 10 for $\$ 3.50$; 50 for $\$ 10.00$; 100 for $\$ 30.00$. EXTRA STANDARD. 65e each; 3 for $\$ 1.75 ; 5$ for $\$ 2.50 ; 10$ for $\$ 4.50 ; 50$ for $\$ 21.00 ; 100$ for $\$ 40.00$, by express, not prepaid.

\section{PEARS}

BARTLETT. Popular everywhere. Large, yellow, juicy pear. September. CLAPP'S FAVORITE. Large; juicy, splendid flavor. August.

FLEMISH BEAUTY. Large, juicy and melting, rich, sweet and excellent flavor. September and October.

KHEFFER. Its large size, handsome appearance and remarkable keeping and shipping qualities make it very profitable for market. October and November.

SEK September and October.

PRECS STANDARD SEZE. \$1.00 each; 3 for $\$ 2.75 ; 5$ for $\$ 4.50 ; 10$ for $\$ 8.50 ;$ by 50 or more at $60 \mathrm{c}$ each; 100 or more at $\mathbf{5 5 c}$ each.

WXTRA STANDARD. $\$ 1.00$ each; 3 for $\$ 2.75 ; 5$ for $\$ 4.50 ; 10$ for $\$ 8.50 ; 50$ for $\$ 3 \% .50$; Bartlett Pear 100 for $\$ \% 0.00$, by express, not prepaid.

\section{PLUMS}

ABUNDANCE (Japan). Large, red, sweet, very juicy, tender and melting. Early.

BURBANK (Japan). Skin dark red over a yellow ground; juicy sweet. Good shipper; ripens a week later than Abundance. Iarge.

GERMAN PRUNE. Purplish-black, medium juicy, large. ning, because of its sweetness.

IMPERIAL GAGE. Large, pale green, juicy, sweet, rich and excellent. Very popular.

LOMBARD. Medium size, red, juicy and sweet. Will grow anywhere and should be in every garden.

PRECES STANDARD SIZE. 90e each; 3 for \$2.50; 5 RICL for $\$ 4.00 ; 10$ for $\$ 7.50$, by parcel post, postpaid. By express, not prepaid: 10 or more at $60 \mathrm{c}$ each; 50 or more at 55e each; 100 or more at $50 \mathrm{c}$ each.

EXTRA STANDARD. 90c each; 3 for $\$ 2.50 ; 5$ for $\$ 4.00$ 10 for $\$ \% .50 ; 50$ for $\$ 32.50 ; 100$ for $\$ 60.00$, by express, not prepaid.

\section{A PLEASEL CUSTOMER FROM OREGON}

"I want to thank you for your prompt shipment of plants I ordered. I surely was surprised at the nice thrifty plants I received. They are sure growing nicely and I am proud of them." Mrs. A. J. Stoldt nicely and I am
Oswego, Oregon.

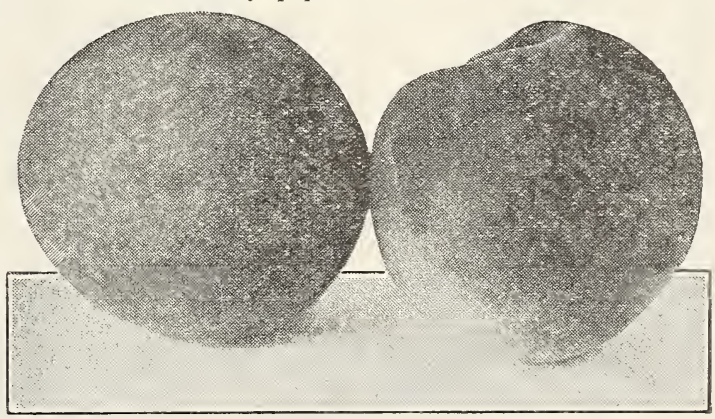




\section{Market Gardeners Wholesale Prices}

Our Market Gardeners' Wholesale Prices are very low. You can't get as good seeds anywhere for less money, or better seeds at any price. We will do our best to maintain these low prices throughout the entire season, but owing to a short crop of some varieties and possible fluctuation in prices due to an unsteady market, we can not absolutely guarantee that there will be no changes on any of the items before the season is over. Market Gardeners' Wholesale Prices are, therefore, subject to change, but we hope we will not have to change any of them, and will not unless it is absolutely necessary.

\section{IMPORTANT NOTICE}

Our Market Gardeners' Wholesale Prices apply only on an order totaling ten pounds or more of seed. That does not mean that you must buy ten pounds of any one variety, lict a total, all told, of ten pounds or more of seed in bulk, entitles you to the Market Gardeners' Wholesale Prices given on this page and pages 77 and 78 . Don't ask us to make a shipment of less than ten pounds at these prices, as we absolutely can not do so. This is a rule that will be strictly adhered to.

Also REMEMBER, seeds sold at our Market Gardeners' Wholesale Prices are not delivered prepaid, but are sent by express, customer to pay the express charges. If it is your desire that shipment be made by parcel post, we can send that way if you will send extra for postage and packing. according to the rates on the schedule of Postage and Packing Charges as shown below. There will be no charge, however, for packing when seeds are sent by express. Only on very short hauls will there be any saving on parcel post shipments, as seeds go at second-class express rates, and with the possible exception of the lower peninsula of Michigan. northern Indiana, northern and western Ohio, northern Illinois and south-eastern Wisconsin, packages of seed weighing ten pounds or more usually go about as cheap or cheaper by express. We would almost always recommend express shipment on seeds shipped in Market Gardeners' Wholesal quantities.

\section{Postage and Packing Charges on Parcel post shipMents at}

Below we have arranged a schedule, according to States, of postage and packing charges on parcel post shipments of seeds ordered at the Market Gardeners' Wholesale Prices. This enables our customers to tell at a glance just how much it will cost them to have us send their seeds by parcei post.

\begin{tabular}{|c|c|c|c|}
\hline $\begin{array}{l}\text { Postage and } \\
\text { Packing Charge }\end{array}$ & $\begin{array}{r}\text { Postage and } \\
\text { Packing Charge }\end{array}$ & $\begin{array}{r}\text { Postage and } \\
\text { Packing Charge }\end{array}$ & $\begin{array}{l}\text { Postage and } \\
\text { Packing Charge }\end{array}$ \\
\hline per $1 b$ & per lb. & per $1 \mathrm{~b}$ & per lb. \\
\hline $\begin{array}{l}\text { Alabama } \ldots \ldots \ldots \\
\text { Arizona } . . .6 \ldots\end{array}$ & & Nevada $\ldots \ldots$. & Carolina \\
\hline $\begin{array}{l}\text { Arizona } \ldots \ldots \ldots \ldots \\
\text { Arkansas }\end{array}$ & $\begin{array}{l}\text { Kentucky } \\
\text { Louisiana }\end{array}$ & New Hampshire & South Dakota \\
\hline $\begin{array}{l}\text { Arkansas } \\
\text { California }\end{array}$ & $\begin{array}{l}\text { Louisiana } \ldots \ldots \ldots \ldots \\
\text { Maine ............ }\end{array}$ & New Jersey .. & $\begin{array}{l}\text { Tennessee } . . . . \\
\text { Texas }\end{array}$ \\
\hline Colorado .........100 & Maryland $\ldots . . . .6$ 6c & $\begin{array}{l}\text { New Mexico } \ldots \ldots \ldots 12 \mathrm{c} \\
\text { New York } \ldots \ldots 66 \mathrm{c}\end{array}$ & $\begin{array}{l}\text { Texas } \ldots \\
\text { Utah } \ldots\end{array}$ \\
\hline Connecticut $\ldots$ & Massachusetts ....8 $8 \mathrm{c}$ & North Carolina ..... $8 \mathrm{c}$ & Vermont... \\
\hline $\begin{array}{l}\text { Delaware } \ldots \ldots \ldots \ldots 6{ }^{6 c} \\
\text { Florida } \ldots \ldots \ldots \ldots 10 \mathrm{c}\end{array}$ & Michigan $\ldots \ldots \ldots \ldots 4 \mathrm{c}$ & North Dakota ..... 8c & Virginia $\ldots$ \\
\hline Georgia $\ldots \ldots \ldots \ldots \ldots$ sc & Minnesota $\ldots . . .8 \mathrm{c}$ & Ohio $\ldots \ldots \ldots \ldots \ldots$ 4c & Washington \\
\hline Idaho ........... & Mississippi $\ldots \ldots \ldots 8 \mathrm{c}$ & Oklahoma...$\ldots .8 \mathrm{c}$ & West Virginia \\
\hline Illinois $\ldots \ldots \ldots \ldots$ & Missouri $\ldots \ldots \ldots 6$ c & Oregon $\ldots \ldots \ldots \ldots 14 \mathrm{c}$ & Wisconsin $\ldots$ \\
\hline Indiana...$\cdots \cdots$ & Montana $\ldots \ldots \ldots$ r2c & Pennsylvania & Wyoming \\
\hline Iowa $\ldots$. & Nebraska $\ldots . . . \ldots 8 c$ & Rhode Island $\ldots . .8 \mathrm{c}$ & Canada. \\
\hline
\end{tabular}

REMGMRP the above charges are made only on seeds sold at Market Gardeners' Wholesale Prices and REMIEMBER, sent by parcel post. There are no postage or packing charges on seeds sold at the regular retail prices quoted in this catalog.

BEANS (Michigan Grown)

Burgess' Everbearing, or Everbearing $\mathrm{Ky}$. Wonder

Burpee's Stringless Green Pod ............

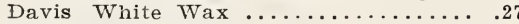

Early Wonder Wax $\ldots \ldots \ldots \ldots \ldots . .30$

Full Measure .......................

Improved Golden wax $\ldots \ldots \ldots \ldots \ldots \ldots \ldots .27$

Improved Michigan Pea or Navy ........ 18

Prolific Black Wax ................26

Refugee or 1,000 to $1 \ldots \ldots \ldots \ldots \ldots \ldots .25$

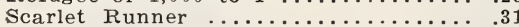

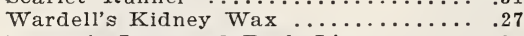

Burpee's Improved Bush Lima .........34

Fordhook Bush Lima ................

Henderson's Bush Lima ...............29

King of the Garden Lima ..............32

Leviathan Lima ...................3

POP CORN (Michigan Grown)

Australian Hulless ............... .23

Black Beauty ......................24

Queen's Golden ...................... .22

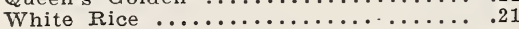

$10 \mathrm{lbs} .100 \mathrm{lbs}$. $\$ 2.40 \$ 21.50$

$2.50 \quad 23.00$

$2.10 \quad 19.00$

$2.30 \quad 21.00$

$2.60 \quad 24.00$

$2.40 \quad 21.50$

$2.30 \quad 21.00$

$1.40 \quad 11.50$

$2.20-20.00$

$\begin{array}{ll}2.10 & 19.00\end{array}$

$\begin{array}{ll}2.70 & 25.00\end{array}$

$2.30 \quad 21.00$

$3.00 \quad 28.00$

$3.20 \quad 30.00$

$2.50 \quad 23.00$

$2.80 \quad 26.00$

$2.90-27.00$

$1.90 \quad 17.00$

$2.00 \quad 18.00$

$\begin{array}{ll}1.80 & 16.00\end{array}$

$1.70 \quad 15.00$
SWEET CORN (Michigan Grown) Lb, 10 lbs. 100 lbs. Country Gentleman .............. \$0.24 $\$ 2.00 \quad \$ 18.00$ De Lue's Golden Giant ............... $\quad .26 \quad 2.20 \quad 19.50$ Early Mayflower ..................27 $2.30 \quad 21.00$ Early Saskatchewan ................30 $2.60 \quad 24.00$ Golden Evergreen ..................25 $.25 \quad 2.10 \quad 19.00$ Improved Golden Bantam ............ .24 $2.00 \quad 17.50$ Stowell's Evergreen ................24 $24.00 \quad 17.50$

PEAS (Michigan Grown)

Alaska $\ldots \ldots \ldots \ldots \ldots \ldots \ldots \ldots \ldots \ldots, .23 \quad 1.90 \quad 17.00$ American Wonder $\ldots \ldots \ldots \ldots \ldots \ldots \ldots, 25 \quad 2.10 \quad 18.50$

Burgess' Drought Proof ..............35 $3.10 \quad 29.00$ Champion of England ................. Dwarfo Gray Sugar $\ldots \ldots \ldots \ldots \ldots \ldots \ldots \ldots .26 \quad 2.20 \quad 20.00$

Horsford's Market Garden . . . . . . . . . .25 $2.10 \quad 18.50$ Hundredfold ....................... $32 \quad 2.80$ Improved Stratagem .............. $\quad .28 \quad 2.40 \quad 21.50$

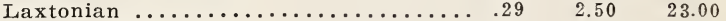

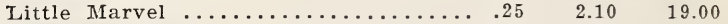
Premium Gem ........................ $24 \quad 2.00 \quad 18.00$ Quite Content $\ldots \ldots \ldots \ldots \ldots \ldots \ldots \ldots \ldots, .28 \quad 2.40 \quad 22.00$ Telephone $\ldots \ldots \ldots \ldots \ldots \ldots \ldots \ldots \ldots \ldots, 25 \quad 2.10 \quad 19.00$ Thomas Laxton ....................... $28 \quad 2.40 \quad 22.00$ may order $5 \mathrm{lbs}$. or over at the 10-1b. rate; $25 \mathrm{lbs}$. or over at the 100-lb. rate. 
DO NOT ORDER at these prices until you have read the IMPORTANT NOTICE and the complete information given on page 76.

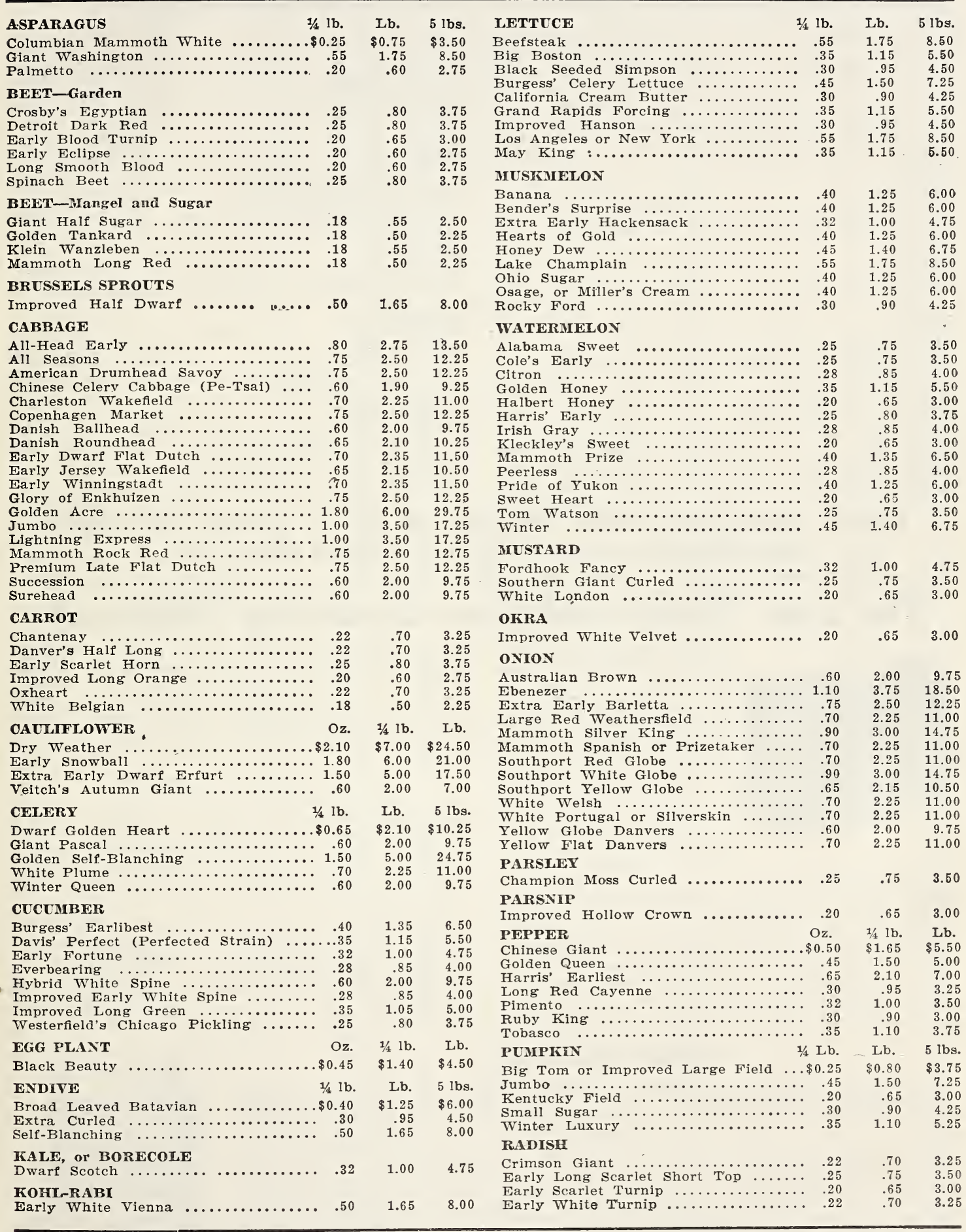


DO NOT ORDER at these prices until you have read the IMPORTANT NOTICE and the complete information given on page 76.

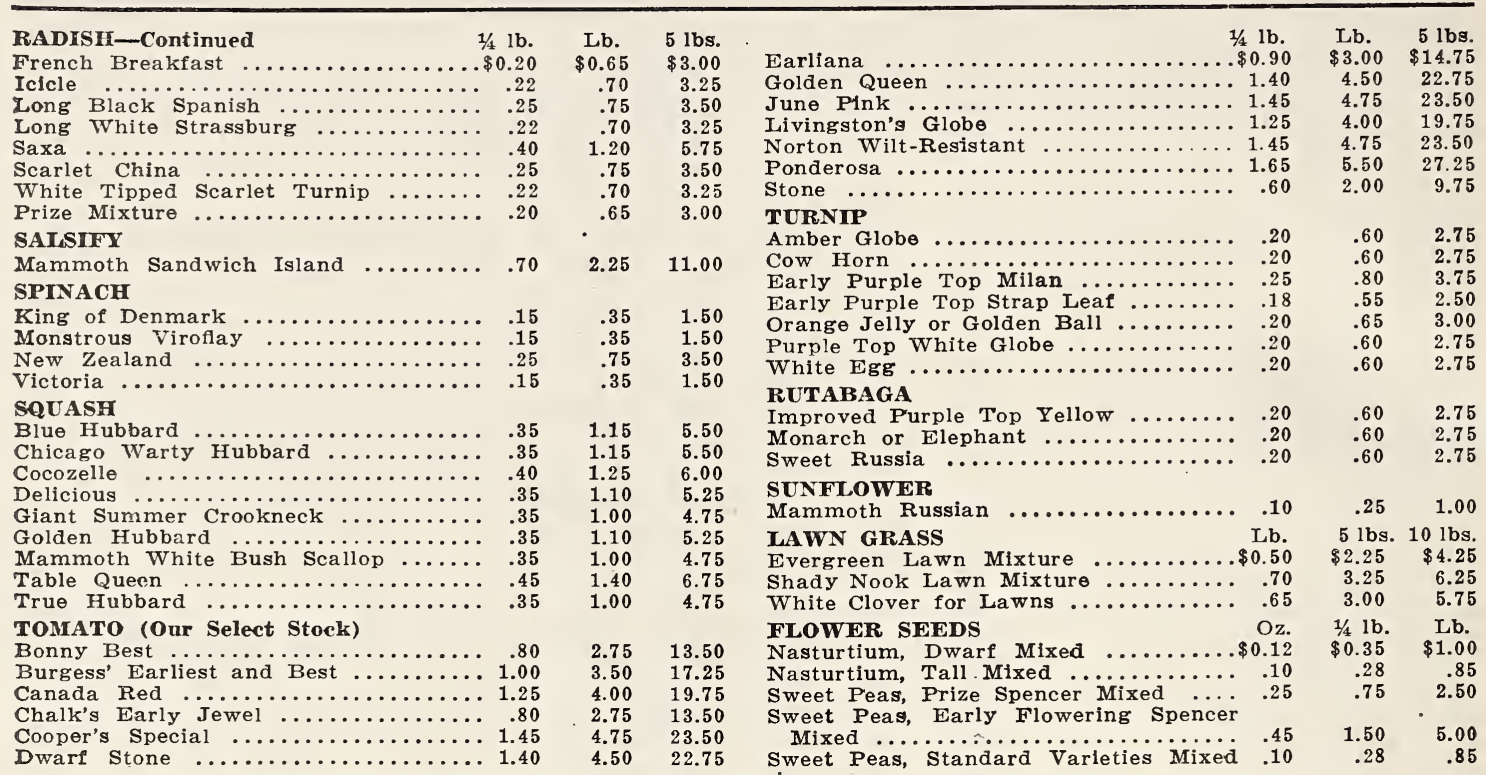

ABOVE PRICES ARE NOT PREPAID and are for quantity buyers only. See information on page 76 before ordering at these prices.

\section{The Last Word in Modern Gardening Efficiency}

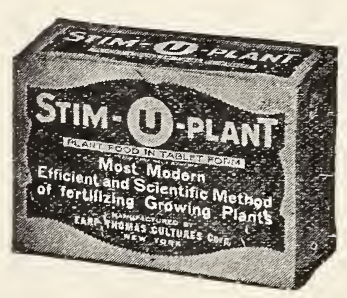

All growing plants-outdoor and in - must be fed if you expect them to produce results, and they respond in a remarkable way to proper feeding. Everything you grow depends on fertilization. STIMU-PLANT will make flowering plants bloom freely and hold their blossoms longer; foliage plants quickly put on new growth; vegetable crops, berry bushes, fruit and other plants increase production, so it pays for itself many times over in a season.

Many fertilizers are slow-acting, their percentage of actual plant food ingredients low and unevenly proportioned. STIM-U-PLANT has guaranteed analysis of 11 per cent nitrogen, 12 per cent phosphoric acid, 15 per cent potash.

EASY TO USE-IMMEDIATE RESULTS-DIRECTIONS WITH EVERY PACKAGE

This wonderful fertilizer and plant food is odorlesshas no obnoxious, messy characteristics. To use, simply

insert a tablet in soil near each plant; or dissolve in water at the rate of four tablets per gallon and use as liquid manure. For plants in drills, put tablets a foot apart along row; in beds, a foot apart each way. Complete, easy directions with every package. Tablets dissolve readily, insuring that the richest kind of plant food goes at once to the plant feeder roots exactly where and when food is needed.

\section{A PROVED SUCCESS}

By using STIM-U-PLANT you save money because it is not wastefully thrown broadcast, nor does it carry weed seeds into your soil. Scientifically made of pure, essential plant food elements, its exceptional richness is correctly proportioned to quickly produce satisfying results on all plant life, whether growing in garden, orchard, "berry patch" or conservatory.

STIM-U-PLANT is a proven success with gardeners and florists. Nothing else equals it as a fertilizer for house plants.

Prices, postpaid: Small size, 25c; 100 tablets, 75c; 1,000 tablets, in bucket, $\$ 3.50$.

\section{SHEEP MANURE}

Pronounced by chemists to be the Best and Safest Fertilizer for everything that grows. A weedless, concentrated manure that puts life and fertility into your soil. No matter what plants you grow, you need manure to secure best results. Wizard is far superior to chemical stimulants and stable manure. It is a real plant food that has a lasting beneficial effect on the soil.

Promotes thick velvety green lawns, a wealth of vivid colored flowers in your garden and vigorous growing shrubbery. In the vegetable garden it produces early crops of crisp tender vegetables. A highly profitable fertilizer for the florist, vegetable grower and home gardener.

Amount to use: Fruits and vegetables, 1,000 to $1,500 \mathrm{lbs}$. per acre. Old lawns, 30 to 60 lbs. per 1,000 square feet. New lawns, 60 to 100 lbs. per 1,000 square feet. Home gardens, 3 to $5 \mathrm{lbs}$. per 100 square feet. Trees, 3 to $5 \mathrm{lbs}$. each. Vines and bushes, $1 \mathrm{lb}$. each. For making potting soil, mix thoroughly one part of sheep manure with six parts soil.

PRICES, by freight, not prepaid: 100 lbs., $\$ 2.50 ; 500$ lbs., $\$ 10.50 ; 1,000$ lbs., $\$ 20.50$; ton, $\$ 40.00$.

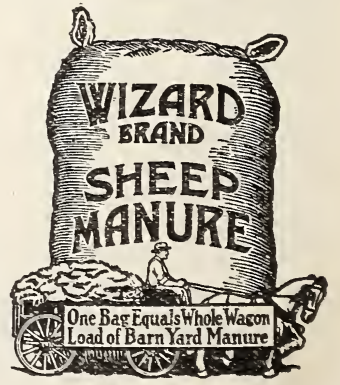




\section{INDEX TO CONTENTS}

Explanation of Table Below. Page numbers prefixed with S, Seeds; P, Plants, Bulbs or Roots.

PAGE

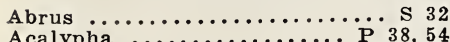
Achillea $\ldots \ldots \ldots \ldots \ldots \ldots \ldots \ldots \ldots$ s $\mathrm{P}$. 32 Ageratum $\ldots \ldots \ldots \ldots \ldots \ldots$. S P 32 Agrostemma .............. S 32 Ailanthus (Tree of Heaven) $\ldots$... Althea ................. P 64 Alyssum $\ldots \ldots \ldots \ldots \ldots \ldots \ldots$ s 32 Amaranthus $\ldots \ldots \ldots \ldots \ldots \ldots$ s 32 Amorpha (False Indigo) ....... P 64 Ampelopsis $\ldots \ldots \ldots \ldots \ldots \ldots \ldots \ldots \ldots$
Anchusa $\ldots \ldots \ldots \ldots \ldots \ldots \ldots$

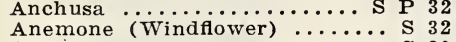
Anise ....................... S 30 Anthemis (Hardy Marguerite)

Antirrhinum $\ldots \ldots \ldots \ldots \ldots$ s $\mathbf{P} 32$

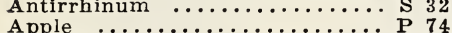
Apricot $\ldots \ldots \ldots \ldots \ldots$ Inside Back $_{\text {Cover }}$ Aquilegia $\ldots \ldots \ldots \ldots \ldots \ldots \ldots \ldots$ s $\mathbf{P} 32$ Arabis (Rock Cress) ........ S P 32 Aralia Spinosa ............ P 64 Arbor Vitae ........... P 68,69

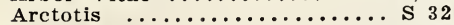

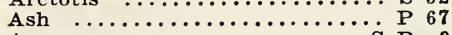
Asparagus $\ldots \ldots \ldots \ldots \ldots \ldots \ldots$ S $\mathbf{S}_{\mathbf{S}} \mathbf{P}_{\mathbf{P}}{ }_{32}$ Asparagus Fern $\ldots \ldots \ldots \ldots \ldots$. S 33

\section{Baby's Breath (See Gypsophila)}

Bachelor's Button (See Centaurea) .................. s 36 Balloon vine $\ldots \ldots \ldots \ldots \ldots \ldots \ldots$ s 33 Balm of Gilead ............. P 67 Balsam (Lady slipper) ......... s 33 Balsam Apple .............. S 33 Balsam Pear ............. s 15, 33 Bartonia Aurea ............. s 34 Barberry (Berberis) $\because \cdots \ldots \ldots$.

Basil $\ldots \ldots \ldots \ldots$ P 55, 64, Back Cover Beans $\ldots \ldots \ldots \ldots \ldots \ldots \ldots \ldots$ S $4,5,6$

Beech ................. P 67 Bets $\ldots \ldots \ldots \ldots \ldots \ldots \ldots \ldots \ldots \ldots$ s ${ }^{\mathbf{P}}{ }^{6}$

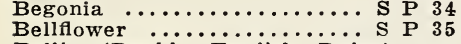
Bellis (Double English Daisy)

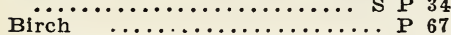
Bittersweet (See Celastrus Scandens) $\ldots \ldots \ldots \ldots \ldots \ldots \ldots \ldots \ldots \ldots$
Blackberry $\ldots \ldots \ldots \ldots \ldots \ldots \ldots$ Blanket Flower (See Gaillardia)

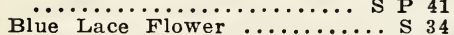
Bocconia ................ Borage $\ldots \ldots \ldots \ldots \ldots \ldots \ldots$ s 30 Borecole (See Kale) ......... S 16
Boston Ivy (See Ampelopsis) ... Box Elder (See Maple)....... P 67 Brachycome (Swan River Daisy) S 34 Brazilian Plume Plant ........ P 35 Bridal Wreath (See Spirea) .. P 55, 64 Broccoli

Brussels sprouts ............ S 7 Burning Bush (See Kochia).... S 43 Buttercup (See Ranunculus)... P 48 Butterfly Bush $\ldots \ldots \ldots \ldots \ldots \ldots \ldots$. P 64
Butternut $\ldots \ldots \ldots \ldots \ldots \ldots \ldots \ldots$ P 67

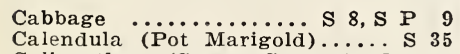
Calicanthus (Sweet $\mathrm{S}$ ce $\mathrm{n}$ t e d
Shrub)

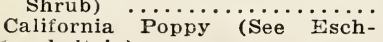
scholtzia) $\ldots \ldots \ldots \ldots \ldots \ldots \ldots$ s 40 Calliopsis $\ldots \ldots \ldots \ldots \ldots \ldots \ldots \ldots \ldots$ s 35 Campanula ................. S P 35 Canary Bird Vine............... S 35 Candytuft .................... s 35

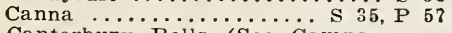
Canterbury Bells (See Campanula)

Caraway $\ldots \ldots \ldots \ldots \ldots \ldots \ldots \ldots$ s 30

Carnation $\ldots \ldots \ldots \ldots \ldots \ldots \ldots \ldots$ s $\mathrm{S} 36$

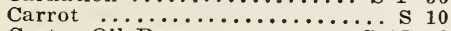
Castor Oil Bean ........... 17,48 Catalpa $\ldots \ldots \ldots \ldots \ldots \ldots \ldots \ldots$ P 67 Cauliflower $\ldots \ldots \ldots \ldots \ldots \ldots \ldots \ldots$ s s $_{7}{ }^{30}$
Celastrus Scandens ......... P 66 Celery ................... s 10 Celeriac $\ldots \ldots \ldots \ldots \ldots \ldots \ldots \ldots \ldots \ldots \ldots \ldots$ s 36,80

Centaurea ............... S P 36

Cerastium $\ldots \ldots \ldots \ldots \ldots \ldots \ldots \ldots$ s $\mathbf{s} 36$

Cherry $\ldots \ldots \ldots \ldots \ldots \ldots \ldots \ldots \ldots$ P 74

Chervil $\ldots \ldots \ldots \ldots \ldots \ldots \ldots \ldots$ s ${ }^{7}$

Chicory $\ldots \ldots \ldots \ldots \ldots \ldots \ldots \ldots$ s 10

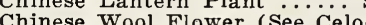

sia) chives $\ldots \ldots \ldots \ldots \ldots \ldots \ldots \ldots \ldots \ldots \ldots \ldots \ldots$ s 36

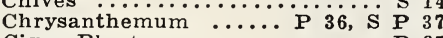

Cigar Plant ............ P 37

Cinnamon Vine ............ P 66

Cineraria

Citron (See Watermelon) ....... s 20

Clarkia .................. s 38

Clematis $\ldots \ldots \ldots \ldots \ldots \ldots \ldots \ldots \ldots$ P 66

Cleome (Giant Spider Plant)... S 37

Cobea scandens ................. s 38

Colchicum $\ldots \ldots \ldots \ldots \ldots \ldots \ldots$ P 58

Coleus .................

Collards .......................... ${ }^{\mathbf{7}} 7$

Comet Plant (Acalypha San-

derii) ................ P 38

Coral Berry (See Symphoricar-

pos) $\ldots \ldots \ldots \ldots \ldots \ldots \ldots \ldots$ P 66

Coreopsis $\ldots \ldots \ldots \ldots \ldots \ldots \ldots$ S $\mathbf{P} 38$

Coriander ................ s 30

Corn, Pop .................. S 12

Corn, sweet ................ s 11

Cornflower (See Centaurea)... S $\mathbf{P} 36$

Corn Salad ................. S 14

Cornus (Dogwood) $\ldots \ldots \ldots \ldots \ldots$. P 64

Cosmos $\ldots \ldots \ldots \ldots \ldots \ldots \ldots \ldots \ldots$ s 38

Cotton, Ornamental ............ S 46

Coxcomb (See Celosia) ......... S 36

Crab, Flowering ........... P 67

Cress .................... s 14

Crimson Flax (See Linum) … S s 44

Crown of Thorns ........... P 38

Cucumber .............. S 12,13

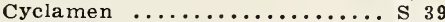

Cydonia Japonica ........... P 64

Cypress Vine ............... s 38

Dahlia ............. S 39, P 57

Daisy... $\mathrm{P} 34, \dot{\mathrm{S}} 39$, $\mathrm{S}$ P 47 , S P 49

Dasheen .............. P 15

Day Lilies $\cdots$ (Perennial Lark-

spur)

Deutzia $\ldots \ldots \ldots \ldots \ldots \ldots \ldots \ldots \ldots \ldots$ S $\mathbf{P} 64$

Dewberry $\ldots \ldots \ldots \ldots \ldots \ldots \ldots \ldots \ldots \ldots$ P 72

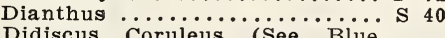

Didiscus Coruleus (See Blue s 34

Digitalis ...............

Digitalis $\ldots \ldots \ldots \ldots \ldots \ldots \ldots \ldots \ldots$ s $\mathbf{P} 39$

Dimorphotheca (African Daisy)

Dogwood (See Cornus) ......... P 64

Dolichos

Dracena Terminalis $\ldots \ldots \ldots \ldots \ldots$ P 55

Dracocephalum (Dragon's Head) S 40 Dusty Miller ............. S 36,37 Dutchman's Pipe ........... P 66

Egg Plant ................ s 14

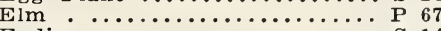

Endive $\ldots \ldots \ldots \ldots \ldots \ldots \ldots$. ${ }^{\mathrm{S}} 14$

Eryngium (Sea Holly) ....... S P 40

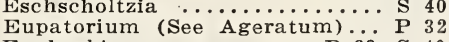
Euphorbia .......... P 38 , S 40 Evening Primrose (See Oeno-

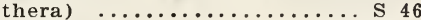

Evergreens $\ldots \ldots \ldots \ldots \ldots \ldots \ldots$ P 68,69

Everlastings $\ldots \ldots \ldots \ldots \ldots \ldots \ldots$ s 40,43

Fennel ..................... s 30

Ferns ........... $\ddot{\mathrm{P}}_{32, \mathrm{P}} 41$

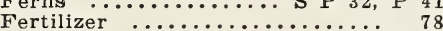

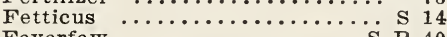

Feverfew $(F) \ldots \ldots \ldots \ldots \ldots \ldots$ s P 40

Forget-Me-Not (See Myosotis)

Forsythia $\ldots \ldots \ldots \ldots \ldots \ldots \ldots$ P $_{64,65,66} \mathbf{S}$

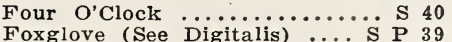

Fringe $\ldots \ldots \ldots \ldots \ldots \ldots \ldots \ldots$ P 65

Fuchsias ............... S P 41

Gaillardia $\ldots \ldots \ldots \ldots \ldots \ldots$. s P 41

Garden Heliotrope ......... S P 51

Garden Huckleberry ......... S 14

Geranium ........... S P 42, P 56

Giant Hyacinth $\ldots \ldots \ldots \ldots \ldots \ldots \ldots$. $\mathbf{P} \quad \mathbf{5}$

Gilia

Ginseng $\ldots \ldots \ldots \ldots \ldots \ldots \ldots$

Globe Amaranth (Gomphrena).. S 41

Gloxinia ................. S 41

Godetia

Golden Glow (See Rudbeckia).. P 48

Golden Seal ............ S P 70

Gourds .............. s 15, 42

Grape ........P Inside Back Cover

Grass, For Lawns ........... S 59

Grass, Ornamental $\ldots \ldots \ldots \ldots$ s 42

Ground Almonds $\ldots \ldots \ldots \ldots \ldots \ldots . . .6$ s 30

Gumbo (See Okra) ............. S 16

Gypsophila (Baby's Breath)... s $\mathrm{s} 42$

Helenium

Helichrysum

Heliotrope

Herbs

$P 43$

Hesperis (Sweet Rocket) .... S P 51

Hibiscus ..P Inside Back Cover, S 42

Hollyhock

Honeysuckle .............. P 65,66

Hop (Humulus) ............... S 43

Hyacinth Bean (See Dolichos).. S 40

Hyacinthus Candicans ....... P $\mathbf{5 5}$

Hydrangea, French or Porch... P
Hydrangea, Hardy . 43

Hydrangea, Hardy $\ldots \ldots \ldots \ldots \ldots \ldots$
Hyssop $\ldots \ldots \ldots \ldots \ldots \ldots \ldots \ldots \ldots$

Ice Plant

Impatiens

Inoculation

S 43

Iris

$4,23,31$

Japanese Quince (See Cydonia

Japonica) ................ ${ }_{\text {Pa }}^{\mathbf{P}}$

Japanese Umbrella

.......... S 43

Job's Tears $\ldots \ldots \ldots \ldots \ldots \ldots \ldots \ldots$. 4 . 43

Juniper $\ldots \ldots \ldots \ldots \ldots \ldots \ldots \ldots \ldots$ P 69

Kale ....................... 16

Kochia $\ldots \ldots \ldots \ldots \ldots \ldots \ldots \ldots \ldots \ldots$ s 43

Kohl Rabi $\ldots \ldots \ldots \ldots \ldots \ldots \ldots \ldots$ s 16

Lady Slipper (See Balsam).... S 33

Lantana $\ldots \ldots \ldots \ldots \ldots \ldots \ldots$. $\mathbf{P} 43$

Larkspur, Perennial (See Delph-

inium)

- S P 39

Lavender $\ldots \ldots \ldots \ldots \ldots$. 30

Leek ...................... s 16

Lemon

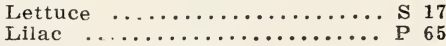

Lily of the Valley .......... P 44

Lilies ............... P 44, 59

Linum $\ldots \ldots \ldots \ldots \ldots \ldots \ldots \ldots \ldots$. . . S 44

Lobelia .............. S P 44

Luffa (Edible Dish Cloth Gourd) S 15

Lupinus ............... S P 44

Lychnis $\ldots \ldots \ldots \ldots \ldots \ldots \ldots \ldots \ldots$ s $\mathrm{P} 44$

Mallow Marvel .... Inside Back Cover Maiva (Musk Mallow) ....... S $\mathrm{S} 42$ Mangel Wurzel .............. S 6 Maple...$\ldots \ldots \ldots \ldots \ldots \ldots \ldots$ P 67 Marguerite, Hardy (See Anthe

$\operatorname{mis} \ldots \ldots \ldots \ldots \ldots \ldots \ldots$ s $\mathbf{P} 32$

Marjoram, Sweet ............. s 30

Martynia $\ldots \ldots \ldots \ldots \ldots \ldots \ldots \ldots \ldots$. 16 


\section{INDEX - Continued}

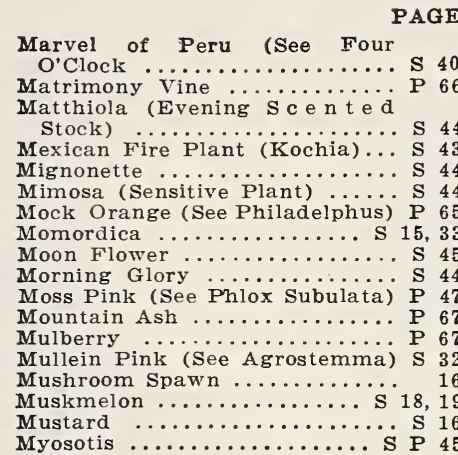

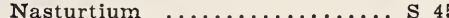
New Guinea Butter Vine........ S 21 Nicotiana ................. S 46 Nigella .................. 5 Night Blooming Jasmine ..... P 46

Oenothera ................. s 46 Okra ................... s 16

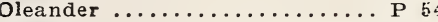

Onion ........... S 21, 22, P 22 Orange $\ldots \ldots \ldots \ldots \ldots \ldots \ldots \ldots \ldots$ P 54 Oxalis $\ldots \ldots \ldots \ldots \ldots \ldots \ldots$ s 46 , P 59

Palm ................ P 55

Pansy ................... S P 46

Parsley $\ldots \ldots \ldots \ldots \ldots \ldots \ldots \ldots \ldots$ s 24

Parsnip $\ldots \ldots \ldots \ldots \ldots \ldots \ldots$ s 24

Peach ................ P 7

Peanut $\ldots \ldots \ldots \ldots \ldots \ldots \ldots \ldots$ s 30

Pear .................... P 75

Peas $\ldots \ldots \ldots \ldots \ldots \ldots \ldots \ldots \ldots \ldots$ s 23,24

Penstemon .............. P 47

Peony ................. P 58

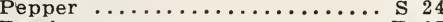

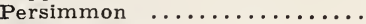

Periwinkle (See Vinca) ..... S S P 52

Petunia $\ldots \ldots \ldots \ldots \ldots \ldots \ldots \ldots$ s 46

Philadelphus .............. P 65

Physalis Franchetti (See Chi-

nese Lantern Plant) ..... S P 36

Phlox ............... S P 47

Physostegia ............. P 47

$\ldots \ldots P$ P 69

Pinks (See Dianthus)

$\begin{array}{ll}\text { S } & 40 \\ P & 47\end{array}$
PAGE

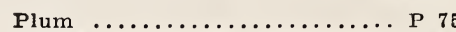

Plume Poppy (See Bocconia) S P 34

Poplar ................. P 67

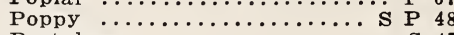

Portulaca ................ S 47

Primrose $\ldots \ldots \ldots \ldots \ldots \ldots \ldots \ldots$ P 48

Privet $\ldots \ldots \ldots \ldots \ldots \ldots \ldots \ldots$ P 55

Prunus Pissardi ........... P 67

Pumpkin $\ldots \ldots \ldots \ldots \ldots \ldots \ldots \ldots$ s 26

Pyrethrum $\ldots \ldots \ldots \ldots \ldots \ldots \ldots$ S P 47

Radish ................. S 25

Ranunculus $\ldots \ldots \ldots \ldots \ldots \ldots \ldots \ldots$ P 48

Raspberry ............. P 73

Red Bud ............... P 67

Resurrection Plant ........... P 54

Rhubarb ............... S P 26

Rhus $\ldots \ldots \ldots \ldots \ldots \ldots \ldots \ldots \ldots$ P 65

Ricinus $\ldots \ldots \ldots \ldots \ldots \ldots \ldots \ldots$ s 17,48

Roses ..........P $60,61,62,63$

Rosemary ................. S 30

Rose of Sharon (See Althea)... P 64

Royal Purple Plant ......... P 49

Rudbeckia .............. P 48

Rutabaga .................. s 29

Sage ................... s 30 Salpiglossis $\ldots \ldots \ldots \ldots \ldots \ldots \ldots$. 4 . 48

Salsify ..................... S 26

Salvia (Scarlet Sage) ......... S 49

Scabiosa .................. s 49

Schizanthus …............ s 49

Sea Holly (See Eryngium).... S P 40

Sea Kale ............... S 26

Sensitive Plant (See Mimosa).. S 44

Shasta Daisy ............ S P 49

Silene .................... s 49

Silk Oak Tree .............. P 49

Smilax ................ S 49

Smoke Tree (See Fringe) ..... P 65

Snake Plant ............. P 49

Snapdragon (See Antirrhinum). S 32

Snowball ............... P 65

Snowberry (See Symphoricarpos) P 66

Snow on the Mountain (See Eu-

phorbia)

spearmint $\ldots \ldots \ldots \ldots \ldots \ldots \ldots \ldots \ldots$ P 30

spinach ................. S 26

Spirea $\ldots \ldots \ldots \ldots \ldots \ldots$ P $55,65,66$

Spruce .................. P 69

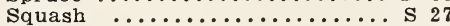

Statice $\ldots \ldots \ldots \ldots \ldots \ldots \ldots \ldots \ldots \ldots \ldots \ldots \ldots$ s $\mathbf{P} 49$

Stocks $\ldots \ldots \ldots \ldots \ldots \ldots \ldots \ldots$ s 51

Stokesia $\ldots \ldots \ldots \ldots \ldots \ldots \ldots \ldots$ S 51

Strawflowers (See Helichrysum) S 43

Strawberry ........... P 71,72

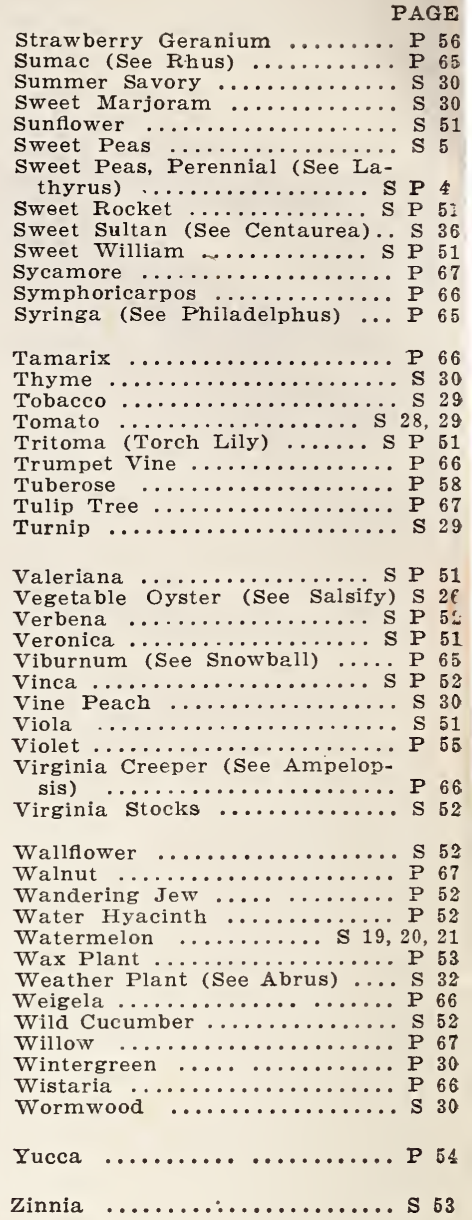

\section{We Deliver Everything Prepaid}

All seeds, plants, etc., listed in this catalog are delivered prepaid at the prices given, except seeds sold at the market gardeners' wholesale prices given on pages 76,77 and 78 , and such other items as are quoted by express, not prepaid.

\section{We Sell Under a Guarantee that Protects the Planter See Our Guarantee on Page 2}

\section{Everlasting Celosia-A Wonderful Novelty}

The Everlasting Celosia (Celosia Spicata) is a beautiful annual that belongs to the same family as Chinese Woolflower; light hilac-pink flowers, borne in elongated heads carried on long and substantial flower-stems. The plants are of upright growth, so that the flowers can be cut with long stems attached. It makes a fine addition to mixed bouquets of annuals or perennials, or may be used for a display in the mixed border. Easily dried for winter bouquets. Pkt., 15c; 2 pkts., 25c. 


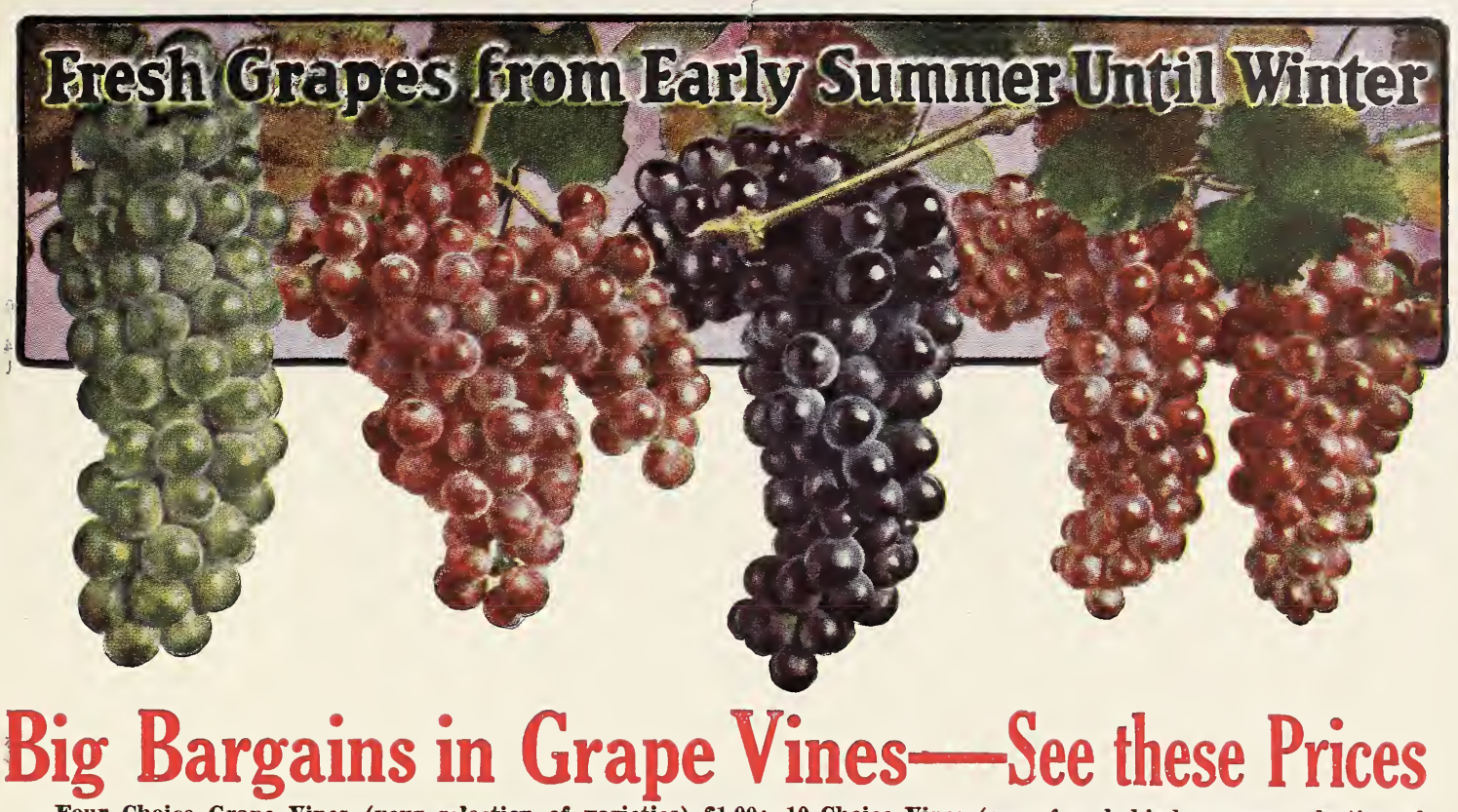

Four Choice Grape Vines (your selection of varieties) $\$ 1.00 ; 10$ Choice Vines (one of each kind, or your selection of varieties) $\$ 2.00 ; 25$ for $\$ 4.50$; 50 for $\$ 8.00 ; 100$ for $\$ 15.00$, delivered, prepaid, anywhere in the United States.

\section{GRAPES Grow Everywhere-On All Kinds of Soil}

The Grape is one of the easiest fruits to grow. There is scarcely a country or city yard or garden so small that space cannot be found to plant one or more Grape Vines. Grapes will thrive anywhere, in any climate or soil. Will do well on soil too poor to raise a crop of grain or other fruit. A Grape vineyard represents a permanent investment

that will pay big dividends every year for a lifetime. We have a fine stock of the following varieties:
AGAWAM. Dark red; large bunch and berry; rich, sweet, aromatic flavor. Ripens closely following Concord. An excellent keeper that may be kept in common storage until January. 35e each, postpaid.

BRIGHTON. Sweet and delicious red Grape. Should be grown in every home garden. Not generally recommended as a commercial variety, as it will not ship to distant markets. Vigorous; productive; ripens two weeks ahead of Concord. 35 c each, postpaid.

CAMPBELL'S EARLY: Black, with purple bloom; large bunch and berry. Juicy, with rich, sweet flavor; hardy; vigorous. Two weeks earlier than Concord. Fruit hangs on vines sound and perfect for ten weeks or more after ripening. 35e each, postpaid.

CATAWBA. Purplish red, bunch large, berries of medium size, with rich vinous flavor, of best quality for both

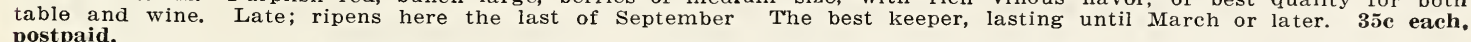

CONCORD. The most widely grown variety. A large, blue-black Grape, ripening about the middle of September in our locality. Will not winterkill; healthy, vigorous vine; large bunch and berry, and will produce more fruit year in and year out than any other sort. Successful in all sections. 20c each; 3 for $40 c ; 6$ for $60 c ; 12$ for $\$ 1.00 ; 25$ for $\$ 2.00$; 50 for $\$ 3.85 ; 100$ for $\$ 7.50$, postpaid. By express, not prepaid: 100 for $\$ 7.00 ; 250$ for $\$ 15.00 ; 500$ for $\$ 27.00 ; 1,000$ for $\$ 50.00$.

DELAWARE is the small, red Grape shown above. No American Grape has more delicate flavor or more pleasing aroma. Ripens with Concord. Brings from 50 to 100 per cent more on the market than other varieties. A hardy, vigorous vine; succeeds both North and South. 35e each, postpaid.

MOORE'S DIAMOND. The best early white Grape for the home garden, ripening about a week before Niagara. White, with rich yellow tinge; unsurpassed in quality and beauty; sweet, juicy, few seeds. Vine hardy, vigorous and
productive. 350 each, postpaid.

MOORE'S EARLY. Similar but larger than Concord and ripens 2 or 3 weeks earlier, the last fruits of it being sent to market before those of the Concord are picked. Vines hardy, vigorous and moderately productive. Its size and earli-

ness make it desirable for early market and home use. 35c each, postpaid.
NIAGARA. The leading white Grape throughout the country. Ranks with Concord in vigor and productiveness, and ripens at the same time. Bunch and berry large and handsome. Tender, sweet, juicy and excellent flavor. 3sc each, postpaid.

WORDEN. Larger berries and bunches than Concord, sweeter, better quality and ripens a week earlier. Fine for the local market and the home garden, but not a good shipper on account of its thin skin. 350 each, postpaid.

\section{SUPERB APRICOT}

\section{Hardy and Ripens a Month Earlier Than Peaches}

Superb is a hardy Russian variety, the best flavored and the most productive hardy Apricot. The fruit ripens a month earlier than early Peaches. As hardy as the hardiest Peach, and usually begins to bear two years after planting. It is very productive. In ness of its skin, it is more like the plum. The Superb has a most delicious flavor and, in addition to being very desirable for eating fresh, is much prized for canning and drying. The Apricot is a delightful addition to any home planting, not only because of the delicious fruit, but for the exquisite beauty of the blossoms. Considered as an ornamental tree alone, the Apricot is unsurpassed. Standard size trees (about 3 feet), $\$ 1.00$ each; 6 for $\$ 5.00$, by parcel post, postpaid. Larger trees by express, not prepaid, at the same price.

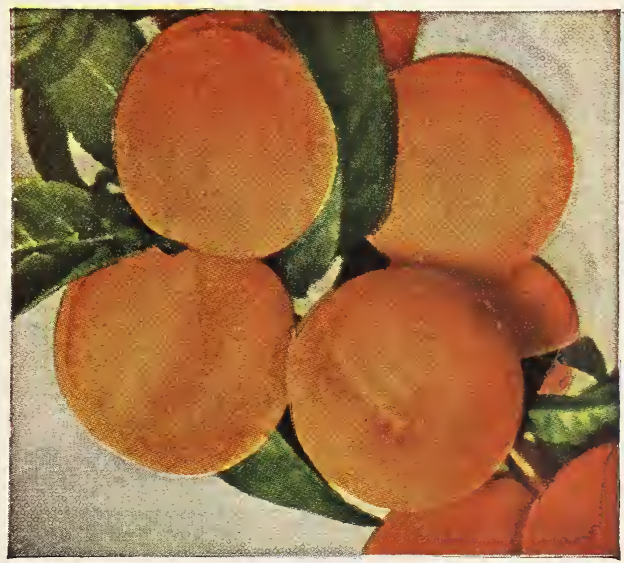

Superb Apricot 


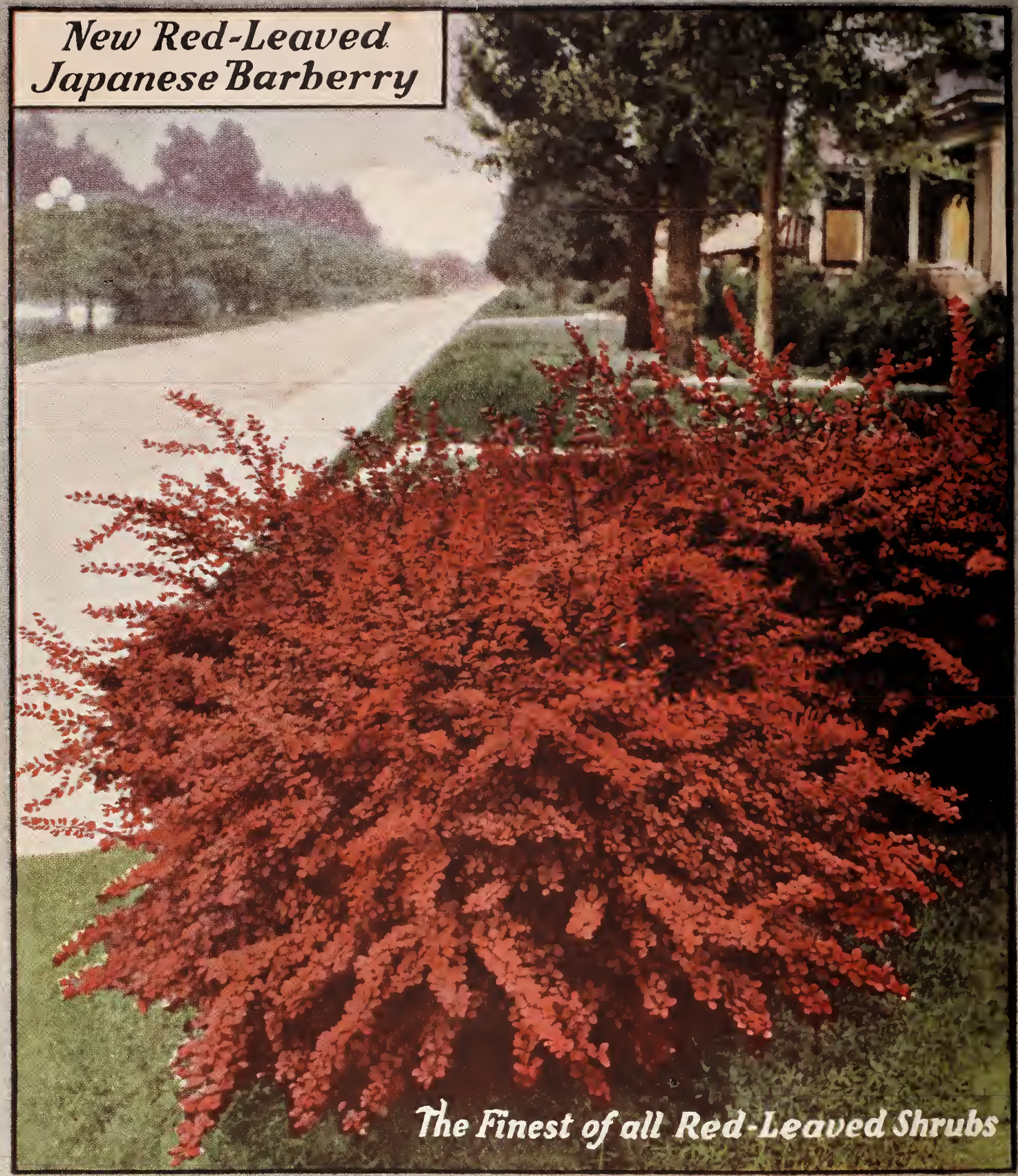

It is only once in a lifetime that a really worth-while, outstanding novelty in hardy shrubs is introduced,
and in this new Barberry we have such a plant.
It is similar in all respects to the green-leaved Japanese Barberry which is so popular for mixing in the
shrubbery border, as single specimens, or for planting in clumps on the lawn, as well as for foundation plant-
ings and for hedges, but the foliage of this new variety is of a rich, lustrous, bronzy red, similar to the richest
red-leaved Japanese Maples. However, unlike these and other colored shrubs in which the coloring fades or
disappears entirely as the season advances, this new Baberry becomes more brilliant and gorgeous throughout
the summer, and in the fall its foliage changes to vivid orange, scarlet and red shades, more brilliant and more
effective than in the ordinary Japanese Barberry. In this coloring it is unequaled by any other shrub and is
followed by the same brilliant scarlet berries common to the type, which remain on the plant the entire winter.
All that is required to develop its brilliant coloring at all seasons is that it be planted in full exposure to the sun.
After rigid tests by the United States Department of Agriculture it has been pronounced a true rust-resisting
sport of the Japanese Barberry The most valuable of all red-logied slirubs.
Extra select plants delivered prepaid, anywhere in the United States, at $\$ 1.00$ each; or 6 for $\$ 5.00$.

\section{Burgess Seed E Plant Co.,Galesburg Mich.}

